\title{
Happiness
}

and Utility

Essays Presented to Frederick Rosen

Edited by

Georgios Varouxakis Mark Philp 


\section{Happiness and Utility}




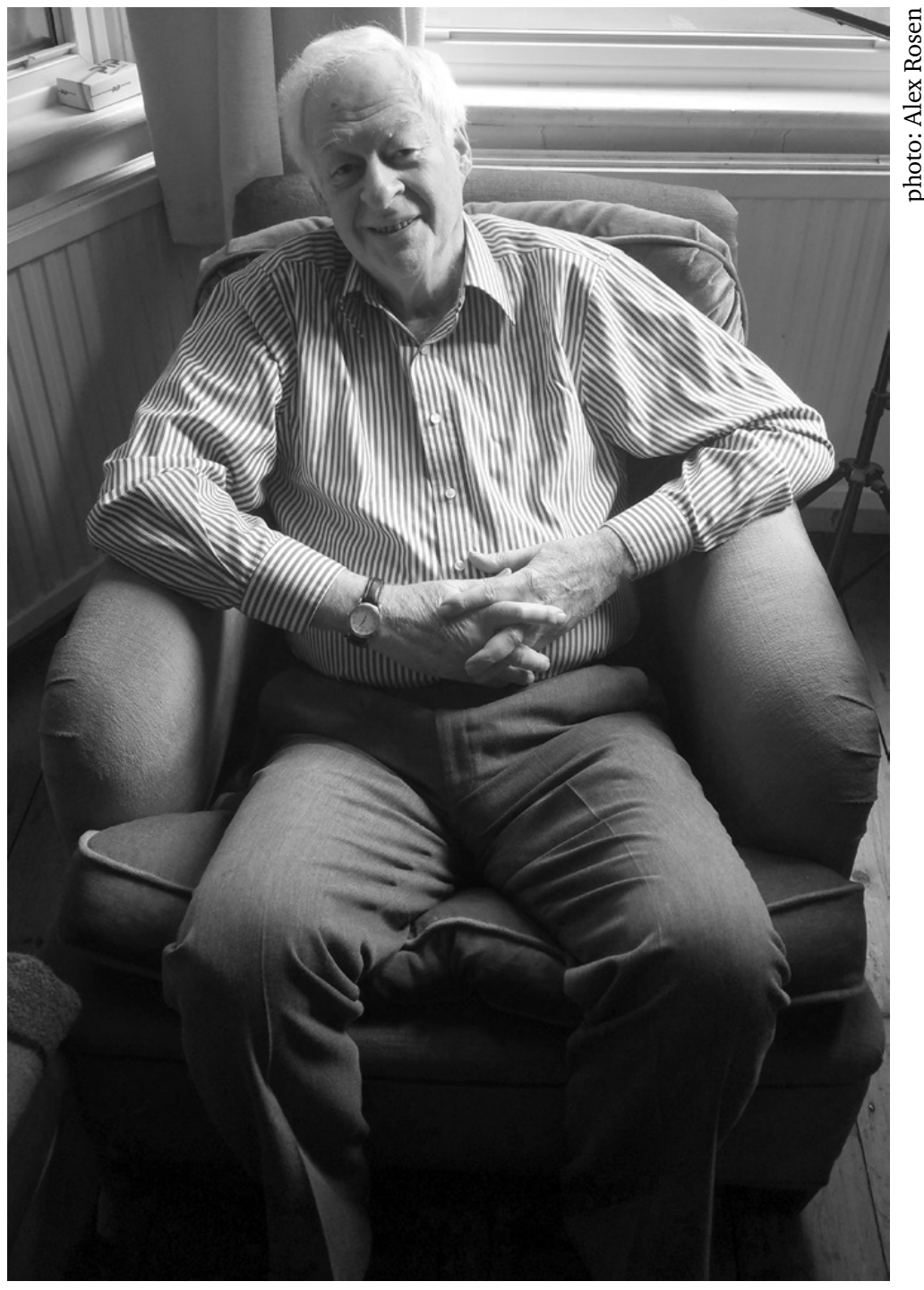

Frederick Rosen 


\section{Happiness and Utility}

Essays Presented to Frederick Rosen

Edited by Georgios Varouxakis and Mark Philp

\section{${ }^{\Perp}$ UCLPRESS}


First published in 2019 by

UCL Press

University College London

Gower Street

London WC1E 6BT

Available to download free: www.uclpress.co.uk

Text (c) the authors, 2019

Collection (C) Georgios Varouxakis and Mark Philp

The authors and editors have asserted their rights under the Copyright, Designs and Patents Act 1988 to be identified as the authors of this work.

A CIP catalogue record for this book is available from The British Library. This book is published under a Creative Commons 4.0 International licence (CC BY 4.0). This licence allows you to share, copy, distribute and transmit the work; to adapt the work and to make commercial use of the work providing attribution is made to the authors (but not in any way that suggests that they endorse you or your use of the work). Attribution should include the following information:

Varouxakis, Georgios and Philp, Mark (eds.) 2019. Happiness and Utility: Essays Presented to Frederick Rosen.London: UCL Press. DOI: https://doi.org/10.14324/111.9781787350489

Further details about Creative Commons licences are available at http://creativecommons.org/licenses/

Any third-party material in this book is published under the book's Creative Commons licence unless indicated otherwise in the credit line to the material. If you would like to re-use any third-party material not covered by the book's Creative Commons licence, you will need to obtain permission directly from the copyright holder.

ISBN: 978-1-78735-050-2 (Hbk)

ISBN: 978-1-78735-049-6 (Pbk)

ISBN: 978-1-78735-048-9 (PDF)

ISBN: 978-1-78735-051-9 (epub)

ISBN: 978-1-78735-052-6 (mobi)

ISBN: 978-1-78735-053-3 (html)

DOI: https://doi.org/10.14324/111.9781787350489 


\section{Contents}

List of contributors vii

Acknowledgements xiv

1. Introduction: Happiness, Utility and the Republic of Letters 1 Mark Philp and Georgios Varouxakis

2. Happiness and Interests in Politics: A Late-Enlightenment Debate

Emmanuelle de Champs

3. Jeremy Bentham and the Spanish Constitution of 1812 Philip Schofield

4. Scepticism and Epicureanism: From David Hume to J. S. Mill James Moore

5. Bentham on 'Hume's Virtues'

José L. Tasset

6. Shaftesbury, Hutcheson and Mill on Pleasure and Virtue Roger Crisp

7. 'The First Article to Look to is Power': Bentham, Happiness and the Capability Approach Michael Quinn

8. Jeremy Bentham and President Roosevelt's Four Freedoms

Manuel Escamilla-Castillo 
9. James Mill on Happiness

Antis Loizides

10. Bentham, Mill, Stoicism and Higher Pleasures

Jonathan Riley

11. Individualist and Totalizing Ethical Thinking in Mill's

Utilitarianism

John Charvet

12. Mill and Democracy: Taking William Buckley Seriously Alan Ryan

13. John Stuart Mill and the Jewish Question: Broadening the Utilitarian Maximand

Samuel Hollander

14. The Failure of Planned Happiness: The Rise and Fall of British Home Colonies

Barbara Arneil

15. Making Better Sense of Ideal Utilitarianism

David Weinstein

Index 


\section{List of contributors}

Barbara Arneil is Professor of Political Science at the University of British Columbia. She works on identity politics and the history of political thought. As the author of John Locke and America (Oxford University Press, 1996) and many related articles, she has a specialization in the intersection between liberalism and colonialism. She is also interested in gender and political theory, and has published Feminism and Politics (Blackwell, 1999; translated into Chinese - Oriental Press, 2005). In it she examines how gender shapes the definition and scope of 'politics'. She has also written a critique of social capital from the perspective of inclusive justice, entitled Diverse Communities: The Problem with Social Capital (Cambridge University Press, 2006) and has published a co-edited anthology entitled Sexual Justice/Cultural Justice (Routledge, 2006). Her most recent work is in the areas of social trust and diversity, global citizenship and cosmopolitanism, the role of disability in political theory and domestic colonies. She has recently published a co-edited book entitled Disability and Political Theory with Cambridge University Press, 2016, and Domestic Colonies: The Colonial Turn Inward, Oxford University Press, 2017. Scholarly recognition includes the Harrison Prize (UK Political Studies Association award for the best article published in Political Studies) and a Rockefeller Foundation Residential Fellowship in Bellagio, Italy; she was also shortlisted for the 2008 C. B. Macpherson Prize (Canadian Political Science Association award for the best book published in Political Theory) and received a UBC Peter Wall Early Career Scholarship, a UBC Killam Research Prize, the 2018 C. B. Macpherson Prize and was co-winner of the 2018 David Easton Award (American Political Science Association Foundations of Political Theory book award).

Emmanuelle de Champs is Professor of British History and Civilization at Université de Cergy-Pontoise. During the academic year 2017-2018 she was Senior COFUND Research Fellow at the Max-Weber-Kolleg, 
Universität Erfurt. She is a specialist in Bentham's utilitarianism and has published several books and articles on intellectual history, including Enlightenment and Utility: Bentham in French, Bentham in France ('Ideas in Context' series, Cambridge University Press, 2015). She has co-edited, with Jean-Pierre Cléro, Bentham et la France: Fortunes et Infortunes de l'Utilitarisme (SVEC, 2009). Her recent work focuses on the late-Enlightenment context in which English utilitarianism emerged.

John Charvet is Professor Emeritus in Political Science at the London School of Economics, UK, where he taught political philosophy and its history for many years. He is the author of many books, including $A$ Critique of Freedom and Equality (Cambridge University Press, 1981), The Social Problem in the Philosophy of Rousseau (Cambridge University Press, 1974), The Liberal Project and Human Rights (Cambridge University Press, 2008; with Elisa Kaczynska-Nay), The Nature and Limits of Human Equality (Palgrave Macmillan, 2013), The Idea of an Ethical Community (Cornell University Press, 1995) and Feminism (Dent, 1982), as well as many papers on political theory.

Roger Crisp is Uehiro Fellow in Philosophy at St Anne's College, Oxford, Professor of Moral Philosophy at the University of Oxford, and Professorial Fellow at the Institute of Philosophy, Australian Catholic University. He has written on meta-ethics (on the nature of ethics, its epistemology and its metaphysics), normative ethics (especially on utilitarianism and virtue ethics) and applied ethics (especially medical ethics, environmental ethics and business ethics). He chairs the Management Committee of the Oxford Uehiro Centre for Practical Ethics. His published work includes: The Cosmos of Duty: Henry Sidgwick's Methods of Ethics (Oxford University Press, 2015), Reasons and the Good (Oxford University Press, 2006), a translation of Aristotle's Nicomachean Ethics (Cambridge University Press, 2000) and the Routledge Guidebook to Mill on Utilitarianism (Routledge, 1997). He was a Leverhulme Major Research Fellow in 2003-2005, and in 2010-2011 he was John Findlay Visiting Professor in Philosophy at Boston University. In 2015-2016, he was awarded a British Academy Thank-Offering to Britain Fellowship, funded by the Association of Jewish Refugees, for work on the history of British moral philosophy.

Manuel Escamilla-Castillo, $\mathrm{PhD}$, Law (University of Granada) and Profesor Titular in Legal and Political Philosophy, is currently Head of the Department of Legal Philosophy at the University of Granada, Spain. He holds the Francisco Suárez Chair of Human Rights and Citizenship, and 
is Director of the academic journal Anales de la Cátedra Francisco Suárez. His latest book is Bentham (RBA, Barcelona, 2017), translated into French (Bentham, Le Monde, Paris, 2017) and Italian (Bentham, RBA, Milano, 2017). Thanks to several leaves and grants from the Spanish Ministry of Education he has taken sabbatical semesters invited by Professor H. L. A. Hart (1981), Professor Sir Neil MacCormick (1988) and Professor Fred Rosen (1995). He was an invited lecturer in the universities of Caen, Westminster, Wyoming, Valencia, Essex, Paris 2, Panthéon-Sorbonne (Doctoral Commission), and Karlova in Prague. He is the Vice-President of the Ibero-American Society of Utilitarian Studies.

Samuel Hollander is University Professor Emeritus at the University of Toronto, Canada, where he served on the faculty from 1963 to 1998. An Officer of the Order of Canada, Fellow of the Royal Society of Canada and Fellow of the Canadian Economics Association, Professor Hollander holds an honorary Doctorate of Laws from McMaster University, Ontario, Canada, and was a Research Director at the Centre National de la Recherche Scientifique (CNRS) of France, 1999-2000. Hollander is one of the most influential and controversial living authors on the History of Economic Thought, especially on classical economics. His monumental studies of Adam Smith, David Ricardo, Thomas Malthus and John Stuart Mill have provoked some sharp reactions, especially his 'new view' of David Ricardo as a direct predecessor of later neoclassical economists such as Marshall and Walras, which has triggered heated debates.

Antis Loizides is Lecturer in Political Theory in the Department of Social and Political Sciences of the University of Cyprus. His research interests include classical reception and the history of political thought, with a special interest in John Stuart Mill and James Mill, and their classical influences. He has published articles in Modern Intellectual History, History of Political Thought, British Journal for the History of Philosophy and History of European Ideas. He is the author of John Stuart Mill's Platonic Heritage: Happiness through Character (Lexington Books, 2013) and editor of Mill's A System of Logic: Critical Appraisals (Routledge, 2014). He is also the co-editor of the books John Stuart Mill: A British Socrates (Palgrave Macmillan, 2013) and Scientific Statesmanship, Governance and the History of Political Philosophy (Routledge, 2015). He is the recipient of research grants from the Research Promotion Foundation, Cyprus, and the A. G. Leventis Foundation, Cyprus. Loizides's latest book is the monograph James Mill's Utilitarian Logic and Politics (Routledge, 2019). 
James Moore is Distinguished Professor Emeritus in Political Science at Concordia University, Canada. Among his many positions, he has been President of the Conference for the Study of Political Thought and President of the Eighteenth-Century Scottish Studies Society. He works on the history of political thought in the era of the Reformation and Enlightenment, and he attempts to trace the ways in which the philosophers of the Enlightenment in Scotland and Reformed Europe responded to the theological, moral and political doctrines of the age of the Reformation. He has held visiting appointments at the universities of Calgary, McGill, Edinburgh, Manchester and Groningen, and at Australian National University and Princeton Theological Seminary. His publications include (with Michael Silverthorne) Natural Rights on the Threshold of the Scottish Enlightenment: The Writings of Gershom Carmichael (Liberty Fund, 2001), Francis Hutcheson on Logic, Metaphysics and Natural Sociability (Liberty Fund, 2006) and Francis Hutcheson on the Meditations of the Emperor Marcus Aurelius (Liberty Fund, 2008). He has worked for years on an edition of the correspondence of Francis Hutcheson (1694-1746). He has also published a wide range of papers on Hume, Natural Law, Montesquieu, Hutcheson and the Scottish Enlightenment.

Mark Philp is Professor of History and Politics at the University of Warwick, and an Emeritus Fellow of Oriel College, Oxford. He has worked extensively in the history of political thought and on political corruption and realist political theory, as well as on late eighteenth- and early nineteenth-century European history. He has edited collections of work by William Godwin, Thomas Paine and John Stuart Mill, and directed the Leverhulme-funded project to digitize and edit William Godwin's diary in 2008-11. Recent publications include: Political Conduct (Harvard University Press, 2007), Reforming Political Ideas in Britain: Politics and Language in the Shadow of the French Revolution (Cambridge University Press, 2013) and, as co-editor, Re-imagining Democracy in the Age of Revolutions: America, France, Britain, Ireland 1750-1850 (Oxford University Press, 2013) and Napoleon's Hundred Days and the Politics of Legitimacy (Palgrave Macmillan, 2018).

Michael Quinn completed his PhD at the London School of Economics under the supervision of Fred Rosen in 1988, and spent four years as a social worker before returning to the Bentham Project at University College London in 2004, where he is currently Senior Research Associate. He has edited Bentham's Writings on the Poor Laws (2 vols, Oxford 
University Press, 2001, 2010), co-edited Of Sexual Irregularities, and Other Writings on Sexual Morality (Oxford University Press, 2014) and is currently completing a five-volume critical edition of Bentham's Writings on Political Economy, of which two volumes have been published (Oxford University Press, 2016, 2019). He has written extensively on various aspects of Bentham's thought, and is currently writing an introductory text on Bentham as a theorist of public policy.

Jonathan Riley is Professor of Philosophy and Political Economy, Tulane University, New Orleans. He earned his DPhil from Oxford University, has published extensively in moral and political philosophy, has received several major awards, including Killam, NEH, NHC and Rockefeller fellowships, and has been a visiting professor at the University of Chicago, the University of St Andrews, Princeton University and the University of Hamburg. His most recent books are Mill's On Liberty (Routledge, 2015), and Mill's Radical Liberalism: An Essay in Retrieval (Routledge, 2003).

Alan Ryan was elected a Fellow of New College, Oxford, in 1969; he later taught at Princeton University, and returned to New College in 1996 to take up the Wardenship. He was made a Fellow of the British Academy in 1986. A political theorist and historian of political thought, Ryan is a highly recognized authority on the development of modern liberalism, and especially the work of John Stuart Mill, having contributed directly to the 'Reversionary' school, which led to a re-examination of Mill's work from the 1970s. He is the doyen of Mill studies. His academic work also takes in broader themes in political theory, including the philosophy of social science, the nature of property, the history of political thought, and liberalism of the nineteenth and twentieth centuries. Ryan has held positions at the universities of Oxford, Essex and Keele, and at Princeton University, Stanford University and the University of Virginia School of Law. He was also a Visiting Professor of Political Science at the University of Texas at Austin, Australian National University, The New School and many others. He is a regular contributor to The New York Review of Books, the London Review of Books, and The Times Literary Supplement, and continues to write on political theory and the history of political thought. His books include studies of Machiavelli, Mill, Dewey, Russell, property and the philosophy of the social sciences, together with the compendious On Politics: A History of Political Thought from Herodotus to the Present (Penguin, 2013).

Philip Schofield is Professor of the History of Legal and Political Thought in the Law Faculty at University College London (UCL). He is 
the Director of the Bentham Project at UCL and the General Editor of The Collected Works of Jeremy Bentham. He has edited or co-edited 11 volumes in the series. His new edition of Bentham's Of the Limits of the Penal Branch of Jurisprudence has superseded H. L. A. Hart's edition of $O f$ Laws in General, as a volume in the new edition of Laws in General. He is supervising work on new, authoritative editions of Bentham's writings on political economy and on Australia. He is the Honorary Secretary of the International Society for Utilitarian Studies (ISUS), a major global network of scholars and students working on utilitarian studies in several different disciplines, under whose auspices major international conferences take place every second year. Professor Schofield was the co-organizer, with Georgios Varouxakis, of the Ninth Annual Conference of ISUS: The John Stuart Mill Bicentennial Conference held at UCL in April 2006. He has published numerous studies related to Bentham, on politics, law, economics, logic and language, political fallacies, sexual morality and related topics. His many publications include Utility and Democracy: The Political Thought of Jeremy Bentham (Oxford University Press, 2006), which was awarded the prestigious W. J. M. Mackenzie Book Prize for 2006 by the Political Studies Association, and Bentham: A Guide for the Perplexed (Continuum, 2009).

José L. Tasset, PhD, University of Seville, Spain (1988), has been Professor of Moral Philosophy at the University of A Coruña, Spain since 1994. Before that, he was Professor of Moral Philosophy at the University of Santiago de Compostela. His basic lines of study and research are David Hume's ethics and the analysis of classical and contemporary utilitarianism. He is now working on a critical study of the Inquiry Concerning the Principles of Morals by Hume, in which the analysis of possible connections to utilitarianism and contemporary virtue ethics is central, and on a Spanish edition of Bentham's Of Sexual Irregularities, and Other Writings on Sexual Morality (forthcoming, 2019). He is a Fellow of the International Society for Utilitarian Studies and of the Hume Society and a founding fellow and current President of Sociedad Iberoamericana de Estudios Utilitaristas (SIEU) (1990), which publishes Tédo૬: Revista Iberoamericana de Estudios Utilitaristas. He is the Director of Té $\lambda$ os.

Georgios Varouxakis BA (Athens), MA (UCL), PhD (UCL) is Professor of the History of Political Thought at Queen Mary University of London, and Co-director of the Centre for the Study of the History of Political Thought. He has been a Research Fellow at University College London, Visiting Research Fellow at Princeton University and Senior Research 
Fellow at the Lichtenberg-Kolleg, University of Göttingen. His books include Liberty Abroad: J. S. Mill on International Relations (Cambridge University Press, 2013), Mill on Nationality (Routledge, 2002), Victorian Political Thought on France and the French (Palgrave Macmillan, 2002) and, as co-editor, John Stuart Mill: Thought and Influence (Routledge, 2010) and Utilitarianism and Empire (Lexington Books, 2005). He is writing a major study on The West: The History of an Idea for Princeton University Press.

David Weinstein is Emeritus Professor, Wake Forest University, USA, and Honorärprofessor, University of Oldenburg, Germany. He received his $\mathrm{PhD}$ in political science from Johns Hopkins University in 1988 . He was a postdoctoral fellow at the Hebrew University of Jerusalem from 1987 to 1988, and has held visiting fellowships and scholarships at Oxford University and Tulane University. In 2009, he was a Fulbright Fellow at the Simon Dubnow-Institut, University of Leipzig, and in 20132014 he was the John Stuart Mill Visiting Professor in Social Philosophy, Universität Hamburg. He has published Equal Freedom and Utility (1998) and Utilitarianism and the New Liberalism (2007), both with Cambridge University Press. He is co-editor, with A. Simhony, of The New Liberalism (Cambridge University Press, 2001) and, with B. Eggleston and D. Miller, of John Stuart Mill and the Art of Life (Oxford University Press, 2010). He is also the co-author, with Avihu Zakai, of Jewish Exiles and European Thought during the Third Reich (Cambridge University Press, 2017). 


\section{Acknowledgements}

The editors would like to thank, above all, Fred Rosen, for his exemplary works and contributions to scholarship and academic life over many decades, and for being an extraordinarily inspiring teacher to so many students over these years. We would like to acknowledge Fred's remarkable capacity for friendship and loyalty, which has gathered around him many people who have benefited from his wisdom and generosity - not least the editors and contributors to this volume. We owe the contributors our thanks for their wonderful chapters as well as for their patience with us and their continued faith in the project. Georgios Varouxakis would like to thank Mark Philp for his limitless patience, calm responsiveness to crises and urgent requests at very short notice and for his very generous companionship through the many stages this volume has gone. That he most kindly volunteered to compile the index was only the latest of many instalments of excessive generosity. Georgios would also like to thank the Lichtenberg-Kolleg (the Institute of Advanced Study of Georg-AugustUniversität Göttingen), for a Senior Research Fellowship during the academic year 2017-18, when most of his share of the editorial work was done. Mark Philp would like to thank Georgios for initiating the project, and for providing that rare thing - a welcome addition to the workload! Both editors would like to acknowledge the generous help of the Centre for the Study of the History of Political Thought at Queen Mary, University of London for its financial support for a workshop at UCL where most of the chapters in this volume were first presented. We are extremely grateful to Professor Philip Schofield and the Bentham Project at UCL for their hosting of that workshop and their financial support for it, and to the Royal Historical Society for allowing us to use its premises at UCL for the workshop. We are also very grateful to UCL Press for publishing this eminently UCL project, and particularly to Ali Moore for her meticulous copy-editing and Jonathan Dore for his remarkable patience and good humour with us at every stage as he steered the project through to completion. 


\title{
1 \\ Introduction: Happiness, Utility and the Republic of Letters
}

Mark Philp and Georgios Varouxakis

\begin{abstract}
'Oh man! ... can someone else know what pleases you better than you do?' (Jeremy Bentham) ${ }^{1}$

'It is better to be a human being dissatisfied than a pig satisfied; better to be Socrates dissatisfied than a fool satisfied. And if the fool, or the pig, is of a different opinion, it is because they only know their own side to the question.' (John Stuart Mill) ${ }^{2}$
\end{abstract}

I.

Happiness was the ultimate end of life in the view of some of the most influential ancient Greek, Hellenistic and Roman philosophers. Happiness is also the end of life according to the modern utilitarian tradition - best exemplified in the works of Jeremy Bentham and John Stuart Mill, but clearly based on deep and lasting influences from both classical philosophy and early modern sources in the Scottish and French Enlightenments. This does not mean either that the view is uncontentious - few Christian sources, for example, between these periods thought of the ultimate ends of mankind as principally concerned with pleasure or happiness - or that it is a clear and uncomplicated idea. What constitutes happiness, how far it is identifiable with pleasure, whether pleasures are comparable and can be calculated or are distinct and in various ways incommensurable - such issues raise often deep philosophical questions about the nature of the good, the character of virtue, and the basis of value in human life. Even when we agree that we want to be happy, it is not clear that we are necessarily envisaging that idea in the same way. ${ }^{3}$ 
This collection of essays pays tribute to the work of our friend and colleague Fred Rosen, who spent the greater part of his academic life wrestling with the philosophy of happiness. Fred has had a distinguished and versatile career. He spent most of his years as an academic before he retired in 2003 at University College London (UCL), leading the editing of the impressive definitive UCL edition of The Collected Works of Jeremy Bentham, and being the Director of the Bentham Project, as well as the Chair of the History of Political Thought in the Department of History at UCL. But he had done quite different things before that. Fred was born in the State of New York and educated at Colgate University and Syracuse University in the US. He then moved to the UK where he completed his $\mathrm{PhD}$ under the supervision of the late Professor Maurice Cranston at the London School of Economics and Political Science (LSE). He had already begun his association with the Bentham Project at UCL by 1965, working for a year as a research assistant under the general editorship of Professor J. H. Burns, before being appointed lecturer at City University, in London. In 1971 he moved to a post in the Department of Government at the LSE. In 1983, Fred was seconded to the Bentham Project to take up what was initially a three-year appointment as General Editor, a post he held until his retirement 20 years later (in the last years as Joint General Editor along with Professor Philip Schofield). Though he was, until his retirement, best known for his penetrating analyses of Jeremy Bentham's thought, Fred has always had wide interests in the broader canon of political thought, in classics, and in the history of utilitarianism, exemplified in his Classical Utilitarianism from Hume to Mill (2003). After he retired, he dedicated himself to a major new study of John Stuart Mill, which was published in the Oxford University Press 'Founders of Modern Political and Social Thought' series in 2013. Much more work on the younger Mill accompanied that research in the form of various publications. He has also had a long-standing interest in ancient Greek political thought, which he taught at the LSE for many years. And besides teaching and publishing on the subject, he animated its study and promotion by running for many years the Society for Greek Political Thought and editing its journal, Polis: The Journal of Ancient Greek Political Thought (which continues to flourish under the editorship of Fred's former student, Professor Kyriakos Demetriou). He was to continue as a journal editor by adding to his record the editorship of The Bentham Newsletter and then, when the latter merged with The Mill Newsletter, of Utilitas, founded in 1989 - which is, happily, still thriving as one of the leading international journals on ethics. And as if Bentham, Mill and the ancient Greeks were 
not enough, his first book was on William Godwin and his publications include work on the twentieth-century French philosopher Simone Weil.

Fred has played a crucial role in the establishment and running of the International Society for Utilitarian Studies (ISUS), which has for decades now been a major global network of scholarly cooperation and interaction and whose biannual international conferences are the highlight of many academics' professional lives. As Philip Schofield emphasizes in Chapter 3, Fred also encouraged and supported the founding of the Ibero-American Society for Utilitarian Studies, two of whose most active members are contributing chapters to this volume. In addition, Fred served for many years as one of the convenors of the Seminar in the History of Political Ideas at the Institute of Historical Research (IHR) of the University of London's Institute of Advanced Studies. He successfully and generously supervised a great number of $\mathrm{PhD}$ students from all corners of the globe, several of whom have become academics in their respective countries teaching 'the Utilitarian or Happiness theory', as one of its main promoters called it. ${ }^{4}$

Utilitarianism has become a crowded philosophical field, but Fred's core contribution to it has been to insist on the importance of taking an interpretative approach that focuses on the author's intentions and way of framing the problem that they seek to answer. Although there is some affinity with the contextualist approach to the history of political thought developed by Quentin Skinner and John Dunn, Fred has also been especially concerned to ensure that we understand how enquiries in one dimension of a thinker's oeuvre connect to other dimensions. Fred's view of Mill's political philosophy, for example, is deeply influenced by his understanding of Mill's Logic. To understand his case in On Liberty, we need to grasp his commitments on secondary principles and his projected science of 'ethology'. Similarly, he takes extremely seriously Mill's engagement with continental thought, and perhaps especially his reaction to Auguste Comte's thinking. One result of this approach is that the Mill most undergraduates encounter in courses on political theory and philosophy is revealed to be a much richer and more complex thinker than the Mill captured in many of the present debates to which students are pointed - on types of utilitarianism, the nature of utility, the connection between liberty and utility, the role of the state in the pursuit of happiness, or the proper grounds for punishment. Moreover, Fred defends a similarly more complex view of Bentham, not least against some aspects of Mill's own interpretation. In the course of his work, he has given us an account of the utilitarian tradition and of the thinking of its key figures, which is 
an essential corrective to the ruthless appropriation of their work by the Anglo-American analytical tradition of political philosophy. He offers us a more human, complex and subtle appreciation of what Mill referred to as the 'Art of Life'. His picture remains committed to the ultimate value of pleasure, but it is one in which a range of secondary principles are essential for the achievement of that end, and those principles necessitate ensuring that there is a very wide area of liberty in which people can choose their path. This approach to Bentham and Mill is at once more careful and faithful to what they wrote, more illuminating about their different areas of interest and commitment, and more cautious in fitting them into modern categories of thinking that are too often anachronisticFred shows, for example, that Mill was not especially interested in moral philosophy, even if that is where most students encounter him! His editing of Bentham and his interpretative work bringing back debates on the founders of this core philosophical tradition at the same time provides us with ways to rethink our own present and its priorities. At the heart of his approach has remained a commitment to helping us think better about the present, by thinking in more sophisticated ways thanks to working in conversation with some of the masters of the past.

In the papers that follow, a group of leading scholars in the wide field of utilitarian studies take up some of the knottiest, most recurrent problems in that field. They bring to it different methodological and disciplinary perspectives, and they are by no means in agreement with all aspects of Fred Rosen's interpretation of the utilitarian canon. But their work is responding to the immense contribution he has made in reanimating debate on the character and legacy of utilitarianism and on the nature of happiness and utility.

\section{II.}

In Chapter 2, Emmanuelle de Champs argues that '[b]y the end of the eighteenth century, happiness was well established in political vocabulary'. And she shows amply that the two thinkers she compares were at the forefront of attempts to make happiness the desirable aim in politics. Her essay uses the shared focus on the vocabulary of 'happiness' in the early thought of both Bentham and Condorcet to make a convincing historical case for studying them 'side by side'. She proceeds to analyse their respective positions on happiness through the lens of the context provided by the influential writings of Helvétius, whose work had a major impact on, and was commented on, by both thinkers. The essay then moves to 
comparing the approaches of Bentham and Condorcet on a number of questions directly related to happiness in the early years of the French Revolution, up to 1791. The events of that year (triggered by the French king's flight and arrest at Varennes) did mark a divide in the responses they evoked on the part of the two thinkers. For that reason, and to avoid projecting later positions onto earlier ones, her paper focuses on sources before 1791. She shows convincingly through focusing on a number of angles and by scrutinizing an impressive number of sources - many of them unpublished manuscript sources - as well as through sharp analysis of similarities and differences, that, in their political thinking, Condorcet and Bentham shared more than has usually been acknowledged. Starting from comparable anthropological foundational premises, both Bentham and Condorcet recognized as the ultimate goal of politics, and as the measure of political success, the advancement of happiness. She also shows that Bentham was more flexible on the potential reconcilability between utility and rights arguments than one would imagine on the basis of his later writings (starting from his notorious attack on rights-rhetoric in Nonsense upon Stilts from the mid-1790s). Neither their respective definitions of happiness nor the status each of them ascribed to the individual was very different, according to de Champs. She identifies striking similarities in their parallel moves towards democratic forms of government, in their emphasis on political equality, in their shared advocacy of the state's duty to secure the conditions conducive to the well-being of individuals, the need for a free public opinion and for enlightening the people through education. However, much was to change with the advent and course of the French Revolution. It was then that a polarization emerged between two types of arguments, one drawing on natural rights and another on utility. But the major contribution of de Champs's essay is to show conclusively that the two respective types of liberalism that are routinely identified around these two different strategies for educating public opinion and legitimating reform were not hermetically distinct from each other but rather 'developed historically together and in constant dialogue with one another'.

Those interconnections become still clearer in Manuel EscamillaCastillo's examination in Chapter 8 of a crucial moment in modern American liberalism, F. D. Roosevelt's 1941 'Four Freedoms' speech. Using Bentham's less florid language, Roosevelt pressed the question of the extent to which a set of concerns that were responding to a desperate political and international moment might find a better formulation in Bentham's legal positivism than in the human rights discourse to which they were subsequently seen as naturally aligned. 
Bentham's stringent semantic hygiene with respect to natural rights is a matter of notoriety, but it is not clear (as de Champs also encourages us to see) that the concerns of those thinking in terms of rights and those thinking in terms of happiness were drawing on very different sources of inspiration. As Escamilla-Castillo shows, there is much to be gained by insisting we restrict rights claims to those legally sanctioned and enforced. But to do so leaves open the question of which ends that law should pursue. For Bentham, those ends should be security, subsistence, abundance and equality. It then becomes an empirical question of exactly what system of legally enforceable claims and guarantees will produce the optimal outcome in terms of those four ends - and while Bentham had strong views about the order of priority, this too must be a question of how far those priorities secure the greatest overall happiness. In making detailed legislative judgements, we must also consider what weight to give to which dimensions in respect to the possible outcomes we believe we can ensure. Moreover, while Bentham does not put it quite like this, we might well ask what forms and dimensions of freedom would best secure his ends. Like Roosevelt, then, we might well say that freedom in terms of conscience and the expression of belief is central, but so too is security and freedom from want (Bentham's 'abundance'). For both Bentham and Roosevelt, we cannot doubt the importance of such conditions for happiness. But it is then a complex matter to work out how to secure these subordinate ends in practice (and exactly what role government should play in doing so). In that process of reflection, it is difficult to see that one can exclude a priori much from the full range of liberal thought, from libertarianism through to social democracy, since each position in the whole range of perspectives offers insights, choices and political goals. The devil is in the detail, and while we probably ought to reject the overblown and distinctly casual rhetoric of much human rights discourse, its objectives do not look that different from Bentham's utilitarian concerns.

In Chapter 4, in a wide-ranging essay on scepticism and Epicureanism from David Hume to J. S. Mill, James Moore follows the combination of scepticism and Epicureanism in the thought of David Hume as well as in the reception of Hume's writings, most notably relating to A Treatise of Human Nature (1739-1740). That reception was not necessarily what Hume would have wished, with the early treatise dominating commentary - rather than the later An Enquiry Concerning Human Understanding and An Enquiry Concerning the Principles of Morals, as Hume would have much preferred. Moore follows the vicissitudes of commentary on Hume's combination of Pyrrhonian scepticism and Epicureanism from 
the time of the publication of the Treatise to the two Mills (James and John Stuart), via Jeremy Bentham and many others. The criticisms that Hume's thought provoked and the debates it generated in Scotland, starting with Thomas Reid and on to Adam Ferguson, are also lucidly highlighted. Hume's attachment to Cicero's moral teachings comes out strongly in the essay. Professor Moore highlights some striking similarities between Hume and the three leading classical utilitarians (Bentham and the two Mills), but also subtly brings out their differences, even where similarities of approach existed. Finally, we would like to draw attention to Moore's observation that 'It is remarkable that nowhere in a book of over 400 pages does [James] Mill ever challenge Mackintosh's repeated characterization of Bentham and his school as Epicureans. "Epicurean", it seems, was a term that did not present a problem for James Mill.' This observation is important, as Antis Loizides agrees in a later chapter, although James Mill's formal subscription to Epicureanism did not mean that his conception of happiness was less complicated than that subscription might at first sight imply.

In 'Shaftesbury, Hutcheson and Mill on Pleasure and Virtue', Chapter 6, Roger Crisp contributes a highly focused comparison of three philosophers who grappled persistently with the relationship between happiness and virtue. Crisp explains that both of the eighteenth-century philosophers he compares with J. S. Mill distinguished between higher and lower pleasures, placed virtue in the category of higher pleasures, and regarded it as an important constituent of happiness. Crisp begins with an analysis of the thought of Shaftesbury, which he stresses was extremely influential in the eighteenth century. Crisp shows that Shaftesbury was staunchly opposed to evaluative hedonism and insisted that consistency can be achieved only through aiming at virtue. Highlighting Shaftesbury's Stoic views on desire, Crisp shows that he put a very high value on contentment or tranquillity. He also shows that Shaftesbury's main argument against unrestricted hedonism was 'solidly Aristotelian'. That is, the pleasures really characteristic of the human being are the pleasures of virtuous action itself. Thus, Crisp establishes that Shaftesbury's objection was not to hedonism per se, but to unrestricted hedonism. He reads Shaftesbury as 'a substantive hedonist about well-being', to the extent that he believed happiness consists 'in pleasurable experiences arising from valuable objects, and in particular the state of mental contentment arising from virtue and virtuous activity'. Therefore 'pleasure in worthless objects is itself worthless'. Crisp offers a detailed critical analysis of a series of interrelated arguments put forward by Shaftesbury to support his conclusion that the life of the virtuous person is the happiest. Crisp 
then moves to analyse Hutcheson's attempts to convince people that their individual greatest happiness lies in virtue. Crisp sees Hutcheson as an evaluative hedonist who held that the happiness of any individual is identical with 'pleasant perceptions', and saw public happiness as consisting merely in the aggregate of such perceptions. Crisp also argues that, like J.S. Mill, Hutcheson 'did not sustain a clear distinction between happiness as pleasure, and happiness as the greatest balance of pleasure over pain within a life'. Crisp highlights the importance of 'dignity', in addition to intensity and duration, in Hutcheson's assessment of degrees of pleasantness or painfulness. He takes Hutcheson to be 'a substantive but not an explanatory hedonist' and scrutinizes Hutcheson's own self-identification within the perfectionist Aristotelian tradition, according to which happiness itself consists in the perfection of one's nature. Crisp concludes by drawing briefly but explicitly the main parallels between the two eighteenth-century predecessors and J.S. Mill and offering a hypothesis as to what the differences of context may allow us to guess regarding Mill's rhetorical strategies.

In Chapter 5, 'Bentham on "Hume's Virtues"', José L. Tasset offers a concise and tightly argued analysis of the main criticisms that Jeremy Bentham levelled against David Hume's theory of virtues. Tasset also highlights the high praise that Bentham had for Hume's originality in many respects - from Bentham's admiration for Hume's distinction between impressions and ideas, through his demolition of the 'fiction' of the social contract, to the oft-quoted passage where Bentham acknowledged that he 'felt as if scales had fallen from my eyes' when he read Hume's attribution of the foundations of virtue in utility. But even in that famous text from his first published book, A Fragment on Government, Bentham was critical of the exceptions Hume had made to the attribution of (almost) all virtues to foundations of utility. Tasset highlights the main attractions of Hume's work for Bentham from very early on, and then moves to analyse Bentham's criticisms. One of Bentham's main objections was that he thought Hume was misguided in conceiving virtues as falling within the domain of intelligence. In contrast, Bentham thought that virtues were always related to the will (for Bentham, 'there is no virtue where there is no struggle. Virtue implies a victory over something.'). But Tasset argues that Bentham misunderstood Hume's use of the word 'mind', which - in Hume's vocabulary - referred to the whole set of mental acts and is not limited to intelligence. It thus included the will. Tasset proposes an answer to Bentham's first criticism in Humean terms by suggesting that an action's voluntary character is not the key to evaluating it as a virtue but rather (he quotes Roger Crisp approvingly) 
'[i]t is ... the durability or the steadiness of moral qualities that leads to their being the primary concern of ethical judgements'. By moving the criterion from the voluntary (or otherwise) nature of acts to questions of the kind 'What qualities should we possess?' or 'Into what kind of person (from our qualities) should we develop?', Tasset argues that moral qualities are justified 'regardless of whether they are natural or artificial, voluntary or not'. That means, as he puts it, that 'we can certainly establish that we must possess them, in so far as they promote utility'.

Even more serious for Bentham was what he saw as a contradiction in Hume's overall thesis on virtues, to the extent that - as Tasset puts it - it first connected virtues with utility as their foundation and then suggested that not all virtues derive their value and approval from utility. Tasset explains that Hume claimed utility was always a source of moral approval, but went on to also say that it was not the sole source of moral approval. However, Hume went on to argue, too, that utility is the sole source of moral approval with respect to some particular virtues such as justice. Bentham took exception to the exceptions and saw their evocation as contradictory to the role of utility in Hume's theory. Tasset argues that in including the exceptions and qualifications, Hume avoided 'falling into what might be called a utilitarian monism'. He also argues that in his refusal to proclaim utility as the foundation of all morality, Hume was 'applying his famous argument about the limited possibilities of reason in ethics and the predominant, non-exclusive and non-excluding role of passions within the domain of morality'.

Antis Loizides contributes an original and impressively documented analysis of James Mill's conception of happiness in Chapter 9. Beginning with the premise that there was much more to James Mill than just the fact that he was the father of John Stuart Mill and the propagandizing agent of Jeremy Bentham (important though those contributions were), Loizides sets out to scrutinize closely an astonishing array of writings of many different genres in which James Mill expressed himself on the meaning and content of happiness. He begins with a section that both elucidates the context and content of classical education in eighteenth-century Scotland, and highlights the extent to which James Mill was unusually deeply immersed in the classics. Besides the elder Mill's compulsive interest in Plato, which Loizides had already analysed in an earlier work, ${ }^{5}$ he emphasizes here Mill's sustained attention to Cicero, a classical thinker who also has an important place in other essays in this volume. Having established the major importance of grasping James Mill's immersion in the classics in any attempt to understand his thought, Loizides then moves to focus on what can be gleaned of Mill's 
conception of happiness from a subtle reading of many arguments found in two sets of his writings, namely those on education and his essays advocating parliamentary reform. Loizides shows beyond doubt that from early on James Mill drew a distinction, which his son later made famous, between higher and lower pleasures - a theme that is also fruitfully discussed in other essays in this volume. ${ }^{6}$ But he goes on to argue that even more important with regard to happiness was the distinction between pursuing one's own happiness or pleasures without concern for others' happiness, on the one hand, and conceiving one's happiness as deriving from one's contribution to the happiness of others. The way Mill thought the latter conception could prevail, Loizides shows, was through education, designed so as to promote the right association of ideas. The passages from Mill's works as well as the unpublished manuscripts that Loizides analyses are striking, and he uses them skilfully to highlight the subtlety of James Mill's proposals for ways in which education and political institutions could be combined to make the promotion of the happiness of the community constitutive of the individual's perception of his/her own happiness.

Political philosophers of happiness are not the natural allies of statesmen and -women in the modern world, but one of the striking features of the work of Bentham and the two Mills is their willingness to attend to the details of constitutional design, so as to ensure that political systems could offer their subjects the best possible chance of securing happiness. Bentham certainly had a penchant for volunteering his advice to legislators. And he was impartial in the distribution of his advice. The French had received their fair share already by the early 1790s, during the turmoil of rapidly changing situations in their great Revolution. And in the early 1820s, the Spaniards were not alone in attracting Bentham's attention and counsel. He also advised the Portuguese to adopt the main outlines of the Spanish Constitution of 1812, with the exception of four all-important amendments that he recommended to them. ${ }^{7}$ The Greeks got some of it as well not long afterwards. ${ }^{8}$ Philip Schofield's essay, Chapter 3, focuses squarely on Bentham's comments on the Spanish Constitution of 1812, basing his analysis on three different sets of Bentham's writings. First there was Bentham's advice to the Spaniards once the Constitution of Cadiz (that had been promulgated in 1812) was restored by the Spanish king under revolutionary pressure from liberals in March 1820. This material began as the substantial essay 'Emancipation Spanish' in the summer of 1820 and was eventually completed by April 1822 under the title 'Rid Yourselves of Ultramaria'. ${ }^{9}$ The second set of commentary on the Spanish constitution comprised a series 
of letters that Bentham began writing in late 1820 and that was eventually published as On the Liberty of the Press, and Public Discussion (July 1821). ${ }^{10}$ The third essay was the letter addressed to the Portuguese mentioned above. Schofield analyses the main arguments Bentham used to warn the Spaniards (and then the Portuguese) of the shortcomings of a constitution of which he approved overall as a step in the direction of progress - recognizing that it established the felicity of the members of the nation as the 'right and proper end of government'. Bentham used his substantial rhetorical skills to praise what was good about the constitution, but he did not mince his words about the serious dangers that he saw lurking behind some of its provisions. He thought that the type of mixed government envisaged was unstable and would sooner or later degenerate in the direction of either despotism or democracy. He castigated what he called the infallibility-assuming clause that forbade any amendments to the constitution for eight years. He poured scorn on the provision for the assembly to meet for only up to four months per year. And Bentham was unhappy about the constitution's stipulation of biannual instead of annual elections to the representative assembly (Cortes).

This latter measure had been justified as necessary for the representatives of the Spanish overseas colonies in Central and South America to be able to participate in the Cortes and travel to and from their constituencies. That was only one of the many problems Bentham saw with the constitution's (and the deputies') clear desire to retain the colonial possessions of Spain. As Schofield's analysis highlights, it was the issue of the colonies, the 'ultramaria', that Bentham was most exercised about. It is not accidental that the major essay commenting on the Constitution of 1812 was titled, in relation to that issue in particular, 'Rid Yourselves of Ultramaria'. This was not the first time Bentham had become exercised by the issues of colonial possessions and their impact on the happiness of all those concerned. Already in 1793 he had used his recently bestowed status as honorary citizen of France to advise the French revolutionaries to 'Emancipate [their] Colonies'. ${ }^{11}$ As in 'Emancipate Your Colonies', Bentham could not resist using, repeatedly, lunar metaphors to emphasize the unrealistic and self-defeating results of the Spanish deputies expecting to rule the distant overseas colonies in Latin America, the 'Ultramaria' (a term he coined, as was his wont). The subtlety and power of the arguments against the possession of colonies and the remarkably effective and witty way in which Bentham formulated those arguments, both in the case of the French in the 1790s and in the case of the Spaniards in the 1820s, have attracted much amply deserved attention in recent years. ${ }^{12}$ 
In Chapter 14, 'The Failure of Planned Happiness: The Rise and Fall of British Home Colonies', Barbara Arneil discusses the neglected topic of repeated attempts by a number of thinkers and activists to promote happiness through the establishment of colonies for marginalized groups within the territory of metropolitan Britain (as opposed to overseas colonization, which was of course on the agenda for others). As Arneil stresses, many of those who proposed such colonies in Britain argued that 'they would create happiness within these groups of fellow citizens who lived miserable lives on city streets'. As she maintains, the existence of the home colonies that she highlights challenges us 'to rethink, in interesting ways, the definition and scope of colonization as well as its relationship to happiness within Britain in the nineteenth century'. Drawing also on her earlier classic work on John Locke's theoretical justifications of the dispossession of indigenous land in seventeenth-century America, ${ }^{13}$ Arneil summarizes the three principles that characterized colonialism as an ideology: 'segregation, improvement and - above all - agrarian labour'. These same principles were used, she shows, by nineteenth- and twentieth-century domestic colonialists, 'but often married to either a utilitarian or consequentialist understanding of happiness'. She notes that it is striking how often justifications for nineteenth-century labour or home colonies for the idle poor used happiness to describe the goal of the colony juxtaposed against the misery of both their current state of unemployment, alcoholism, corruption or criminality as well as the life they would face in alternative institutions such as prisons, workhouses or emigration'. For example, she demonstrates that Robert Owen's attempts to promote home colonies were striking in their emphasis on happiness as the end of such colonies - and as justifying the argument of another scholar quoted by Arneil that 'Utility or the pursuit of happiness' was the starting point of Owenite philanthropy. Happiness was also the explicit aim of the labour colony created in Lindfield, Sussex, by the Quaker William Allen in 1823. As Arneil explains, besides being initially closely allied to Robert Owen, Allen was also a close associate of James Mill and Jeremy Bentham. The imaginative parallel between the aspirations of internal colonization and those of colonization by European settlers overseas is made remarkably clear in the episodes Arneil discusses, with Allen's Lindfield colony being persistently referred to as 'America' or 'new America'. As she pointedly puts it, 'Locke's famous words "all the world was America" take on a new meaning here.'

The most influential domestic colonialist of the late nineteenth century was the founder of the Salvation Army, William Booth. The urbanbased centres for which the Salvation Army is known today - revealingly 
called 'city colonies' by their founder - were seen by him 'as mere conduits to the central feature of his plan': the domestic farm colony. The explicit association between domestic and overseas colonialism is again highlighted by Arneil's analysis of Booth's direct parallel between 'darkest Africa' and 'the "submerged tenth" or idle poor of "darkest England" in his characteristically entitled book In Darkest England: The Way Out (1890). Booth emphasized the connection between domestic and overseas colonialism by presenting the domestic colonies and part of the preparation needed for the Salvation Army eventually to send colonists to an overseas colony owned by it. But, like the Jewish migrants who were to be sent to Palestine by the Zionist movement in the twentieth century, they needed to be prepared and experienced in cultivating the land before going to overseas colonies. As with Owen and Allen, 'happiness' is also ubiquitous in Booth's writings quoted here by Arneil.

In her conclusion, Arneil assesses the various explanations proffered to account for the rapid and spectacular failure of the various projects discussed in her chapter and rejects them. Instead she argues that their failure rather lies 'in the ideology of colonialism itself - namely, the central principle that it is possible to engineer the happiness of the poor through detailed plans based on the principles of segregation and engagement in agrarian labour and spade husbandry'. Arneil's essay establishes an important link between domestic settler colonialism and ideologies of imperialism in British political thought. ${ }^{14}$

The mention of Palestine and Zionism above leads us to Samuel Hollander's Chapter 13, on 'John Stuart Mill and the Jewish Question'. Hollander takes as his starting point the argument by Edward Alexander to the effect that 'John Stuart Mill was neither anti-Semite nor philo-Semite, but a tertium quid foreshadowing a political type' that Alexander went on to describe as modern-day Israel's 'ideological enemies ... [who] have long done battle with that straw man they call "Zionists who want to silence all criticism of Israel", mythical creatures nobody has ever been able to identify ... '. ${ }^{15}$ Hollander takes issue with the implications of Alexander's classification of Mill and the modern-day lineage implied for him by that classification. Hollander sets out to show that Mill was not prey to anti-Jewish prejudice and, instead, 'that honest critics [of Israeli policies] may rest assured that they are following in Mill's footsteps'. ${ }^{16}$ Hollander first assesses the evidence on Mill's historical evaluation of the Old Testament and Jewish morals - which, he convincingly shows, evolved through his reading of particular works of biblical scholarship, especially Joseph Salvador's Histoire des Institutions de Moïse et du People Hébreu (1828) some time around 1840. He shows that Mill's overall assessment was far from negative, by drawing attention 
to Mill's evaluation of the contribution of Judaism to the rise of monotheism and, not least, his extraordinarily high evaluation of the importance of the Jewish prophets as being conducive to progress not just for the Jews but in terms of universal history. That he put the Jews on the same league in terms of conduciveness to progress as his notoriously beloved Greeks speaks for itself. ${ }^{17}$ Hollander brilliantly captures the importance of this argument and in the end comes back to build his conclusion on its importance and contemporary implications.

Hollander then moves to contextualize Mill's comments on the 'primitive' nature of Old Testament ethics by focusing on some of Mill's related comments on Christian ethics, showing that Mill's 'animus is directed not against Judaism but primarily against Christianity for its lack of social content, including "duty to the State", thereby falling short of the morality even of "of the best Pagan nations". ${ }^{18}$ That is followed by an analysis of the concrete positions Mill took on a number of contemporary issues and policy debates involving the status of Jews in the United Kingdom - including Mill's staunch support for the removal of Jewish political disabilities, neutrality in education and, most interestingly, Mill's support for Saturday as the day of rest for Jews on the grounds of their religious obligation, while he was against compulsory Christian observance of Sunday. On all of these issues Hollander shows Mill staunchly defending the principles of 'civil equality and religious liberty'. And Hollander emphasizes the importance Mill attributed to insisting on principles for the promotion of a society's happiness.

The papers in this collection include a group that focus in various ways on the issue of how we should understand the central idea of the utilitarian tradition - happiness. This is a complex matter that raises questions both about how to interpret the classical texts of the tradition, and how to understand the idea itself. Jonathan Riley, for example, focuses in Chapter 10 on Fred Rosen's suggestion that J. S. Mill builds a degree of distance from Bentham's position by engrafting elements of the Stoic tradition into his understanding of happiness - enabling him to claim that it is better to be Socrates dissatisfied than a fool satisfied, which, on the face of it, puts happiness second to a story of the intrinsic merits of the virtuous life (which derives from the Stoic account). Riley's argument involves two distinct moves, both of which merit further work: one dealing with the way in which we should read Bentham's account of the variety and commensurability of the pleasures; and the other concerning whether or not it is necessary to include Stoic elements in the base of Epicureanism in utilitarianism in order to create a place for virtue. Mill clearly felt Bentham's account was lacking in certain ways, in particular with reference to the 
idea of higher pleasures and their commensurability, although it is moot as to whether his understanding of Bentham actually does justice to the now extensive published oeuvre of Bentham. But it is also contentious that Mill needs Stoicism for his own account - and that he sought to engraft it. Riley gives us good reasons to rethink what have been two long-standing traditions: one started by Mill in faulting Bentham over happiness and its relationship to virtue and the higher, more abstract, forms of motivation that go beyond the bare pursuit of pleasure; and the other thinking that Mill is in an important respect conditioning and modifying the central formula of utilitarianism, the pursuit of happiness.

John Charvet raises a similarly vexed issue in Chapter 11 with regard to Mill's utilitarianism, focusing on the question of whether the aim of maximizing total utility/pleasure/happiness comes with any necessary commitment to equality in the distribution of that good. One principal concern is whether, if we assume the validity of an ideal account of utility, it could be legitimate to sacrifice the many lower pleasures of the majority, so as to safeguard the few higher pleasures of the few. He demonstrates that at least some philosophers, such as Hastings Rashdall, have been prepared to advocate the legitimacy of that sacrifice. But the question in relation to Mill is whether the same holds true, and if it does not, does that involve appealing to something other than the perspective of someone trying to achieve the greatest overall utility? One possible alternative source of appeal is to the rules of justice, as discussed in Mill's Utilitarianism. But Charvet shows that while this is a more attractive line than that of the direct maximizing perspective, it is not something that can be justified by that latter perspective. One plausible conclusion from this is that this maximizing perspective is one that we cannot plausibly adopt, and that we ought instead to take a stand on the equal interests of all members of the community. However, the fact that there remains an irresolvable tension between the two perspectives seems to point to a major challenge to utilitarianism.

The issue of the nature of virtue and its relationship to happiness in the development of an ideal utilitarianism is picked up and developed by David Weinstein in Chapter 15, in an essay that explores late nineteenth- and early twentieth-century discussions of the utilitarian legacy, focusing in particular on the attempt to vindicate a form of ideal utilitarianism from both the utilitarian writings of Henry Sidgwick and the idealism of T. H. Green. What Weinstein shows is that some of the attacks made on idealism and classical utilitarianism by G. E. Moore rely on very flawed interpretations of the texts he criticizes - particularly those of T. H. Green - so that the development of a form of ideal utilitarianism 
(identified by Moore but only later named by Hastings Rashdall) is driven by an imperfect understanding of the doctrines against which he believed himself to be reacting. What we learn from this is that the contrast between ideal utilitarianism and idealism - which is drawn so strongly in standard accounts of the debates of the late nineteenth century - actually obscures considerable affinities between these thinkers and the way they understand the good and the ideal in terms of their relationship to pleasure.

The importance of attending to what theorists of the past say is underlined also by Michael Quinn's careful discussion of Bentham's account of happiness in Chapter 7. His starting point is Amartya Sen's development of the capabilities approach as a way of resisting utilitarianism. Sen is hardly alone among modern political philosophers in thinking that neither a doctrine of rights, nor a version of welfare utilitarianism, can generate a sufficiently attractive account of how we should think about the appropriate metric for distribution in a modern society. What Quinn shows, however, is that there is little in the capabilities account to which Bentham did not in fact commit - and that Bentham's thinking is poorly understood if we do not recognize his commitment to the importance of freedom, and his recognition of the significance of equality within a society. Quinn demonstrates, as do so many of the papers in this collection, the importance of attending with great care to the founders of the utilitarian tradition, whose thinking is often hugely more sophisticated and subtler than either they acknowledged in their criticisms of each other, or than we recognize in the construction of the Western canon of political thought.

This is not to say that Bentham and Mill are uncriticizable. As Alan Ryan shows in Chapter 12, while there is much to admire in John Stuart Mill, there are also problems. As an early and enthusiastic reader of Tocqueville, Mill should have been keenly aware of the difference between the social dimension of democracy and its political dimension. Moreover, his enthusiasm for ancient Greek politics, which led him to anticipate a body of citizens devoted to the public good, also fuelled his dislike of professional politicians and bureaucrats. But, according to Ryan, he failed to give serious attention to the problem of which social conditions could systematically generate the kind of enthusiasm for citizen politics necessary to keep the government of a society out of the hands of experts, politicians and bureaucrats. When we look at the challenge faced by modern democracies, we seem to have little choice but to accept a political order we might hope to hold to account on some points, but which is not going to be dominated by an active citizen body. And we face this problem 
because that kind of politics demands a kind of society that is unlikely to be attractive to the vast majority of its members. Tocqueville worried away at this problem in the course of his life; however, argues Ryan, Mill seems to have been curiously reticent about the problem, and curiously confident that active citizen involvement could provide an adequate form of political accountability for the elite. As Ryan shows, one of the things we can learn from this is the importance of asking what the conditions of feasibility are for particular conceptions of the political order, and how far the way in which modernity has developed simultaneously realizes elements of Mill's vision in terms of a plurality of ways of life, while rendering some of his other aspirations hopelessly impractical.

The papers in this collection draw on a variety of disciplinary perspectives and methodological approaches. Individually, they raise important questions on how to think about some of the core issues in the utilitarian tradition, and particularly in the work of its three seminal figures: Jeremy Bentham, James Mill and John Stuart Mill. They help us to appreciate some of the sources and debates from which the golden age of utilitarian thinking developed, and they demonstrate some of the complexities and subtleties of these writers' thinking. They also help us see how the utilitarian tradition developed subsequently and raise issues about its continuing relevance. In doing so, for all their critical engagement with his work, they necessarily pay homage to the work of Fred Rosen, who has spanned precisely this broad range of concerns in his long engagement with the political theory of utilitarianism, its ancient roots and its continuing significance.

\section{Notes}

1. Quoted in: Emmanuelle de Champs, 'Happiness and Interests in Politics: A Late-Enlightenment Debate', Chapter 2 in this volume. The translation is de Champs's from a Bentham manuscript at UCL Library.

2. John Stuart Mill, 'Utilitarianism', in The Collected Works of John Stuart Mill, ed. F. E. L. Priestley (subsequently by John M. Robson), Vol. X, Essays on Ethics, Religion and Society (Toronto: University of Toronto Press, 33 vols, 1963-1991), 212.

3. Aristotle's eudaemonia, for example, is one account of the telos of human existence in terms of happiness, but it is one that does not sit naturally with later tendencies to understand happiness largely in terms of pleasures that are rooted in human physiology.

4. Mill, 'Utilitarianism', in The Collected Works of John Stuart Mill, Vol. X, 207.

5. Antis Loizides, 'Taking Their Cue from Plato: James and John Stuart Mill', History of European Ideas 39/1 (2013): 121-40.

6. See in particular Roger Crisp, 'Shaftesbury, Hutcheson and Mill on Pleasure and Virtue'.

7. See Jeremy Bentham, 'Letter to the Portugueze Nation, on Antiquated Constitutions; on the Spanish Constitution Considered as a Whole, and on Certain Defects Observable in it' (1821), in On the Liberty of the Press, and Public Discussion and Other Legal and Political Writings for Spain and Portugal (The Collected Works of Jeremy Bentham, UCL Bentham Project edition), ed. Catherine Peace-Watkin and Philip Schofield (Oxford: Oxford University Press, 2012), 101-8. 
8. See Jeremy Bentham, Securities Against Misrule and Other Constitutional Writings for Tripoli and Greece, ed. Philip Schofield (Oxford: Clarendon Press, 1990).

9. See Jeremy Bentham, Colonies, Commerce, and Constitutional Law: Rid Yourselves of Ultramaria and Other Writings on Spain and Spanish America, ed. Philip Schofield (Oxford: Oxford University Press, 1995).

10. Jeremy Bentham, On the Liberty of the Press.

11. See Jeremy Bentham, 'Emancipate Your Colonies! Addressed to the National Convention of France, 1793, Shewing the Uselessness and Mischievousness of Distant Dependencies to an European State', in Rights, Representation and Reform: Nonsense upon Stilts and Other Writings on the French Revolution (part of: The Collected Works of Jeremy Bentham), ed. Philip Schofield, Catherine Pease-Watkin and Cyprian Blamires (Oxford: Clarendon Press, 2002), 289-315.

12. For some examples among many, see: Jennifer Pitts, A Turn to Empire: The Rise of Imperial Liberalism in Britain and France (Princeton: Princeton University Press, 2005); Jennifer Pitts, “"Great and Distant Crimes": Empire in Bentham's Thought', in Jeremy Bentham: Selected Writings, ed. Stephen G. Engelmann (New Haven and London: Yale University Press, 2011), 478-99; Donald Winch, Classical Political Economy and Colonies (London: The London School of Economics and Political Science - G. Bell and Sons, 1965); Donald Winch, 'Bentham on Colonies and Empire', Utilitas 9/1 (1997): 147-54; Philip Schofield, Utility and Democracy: The Political Thought of Jeremy Bentham (Oxford: Oxford University Press, 2006); Peter Cain, 'Bentham and the Development of the British Critique of Colonialism', Utilitas 23/1 (2011): $1-24$.

13. Barbara Arneil, John Locke and America: A Defense of English Colonialism (Oxford: Oxford University Press, 1996).

14. For recent work on the latter, see Duncan Bell, Reordering the World: Essays on Liberalism and Empire (Princeton: Princeton University Press, 2016).

15. Hollander quotes from Edward Alexander, The State of the Jews: A Critical Appraisal (London and New York, Routledge: 2012), xiv.

16. Mill has been - very briefly - treated as closer to philo-Semite than in Alexander's book. See Gertrude Himmelfarb, The People of the Book: Philosemitism in England, from Cromwell to Churchill (New York and London: Encounter Books, 2011), p. 77fn. Himmelfarb does not offer anything like a full assessment. She only draws attention to Mill's strikingly positive evaluation of the role of ancient Jewish prophets - which Hollander discusses extensively in the chapter here.

17. The Collected Works of John Stuart Mill, XIX, 396-7. These arguments about which societies become stagnant and which remain continuously progressive, and the reasons that account for each of the two outcomes, are strikingly reminiscent of Mill's writing in many other works and letters. Mill found this idea (and adopted it enthusiastically) in François Guizot's Histoire de la Civilisation en Europe (1828). From some time in the early to mid-1830s when he read that work, Mill started talking of the paramount importance of diversity and struggle, and the need to keep up an 'organized antagonism' in society if progressiveness were to be preserved and stagnation avoided. See Georgios Varouxakis, 'Guizot's Historical Works and J. S. Mill's Reception of Tocqueville', History of Political Thought 20/2 (1999): 292-312.

18. Thus, arguably something similar to what was the case with Voltaire's (much more extensive and much harsher) comments on Judaism in his attempts to discredit Christian-centred universal histories might be said to have been at work in the few cases where Mill commented on Old Testament morality. Cf. Adam Sutcliffe, Judaism and the Enlightenment (Cambridge: Cambridge University Press, 2003), 231-46.

\section{Bibliography}

Alexander, Edward. The State of the Jews: A Critical Appraisal. London and New York: Routledge, 2012.

Arneil, Barbara. John Locke and America: A Defense of English Colonialism. Oxford: Oxford University Press, 1996.

Bell, Duncan. Reordering the World: Essays on Liberalism and Empire. Princeton: Princeton University Press, 2016. 
Bentham, Jeremy. Colonies, Commerce, and Constitutional Law: Rid Yourselves of Ultramaria and Other Writings on Spain and Spanish America (part of: The Collected Works of Jeremy Bentham, UCL Bentham Project edition), edited by Philip Schofield. Oxford: Oxford University Press, 1995.

Bentham, Jeremy. 'Emancipate Your Colonies! Addressed to the National Convention of France, 1793, Shewing the Uselessness and Mischievousness of Distant Dependencies to an European State'. In Rights, Representation and Reform: Nonsense upon Stilts and Other Writings on the French Revolution (The Collected Works of Jeremy Bentham), edited by Philip Schofield, Catherine Pease-Watkin and Cyprian Blamires, 289-315. Oxford: Clarendon Press, 2002.

Bentham, Jeremy. 'Letter to the Portugueze Nation, on Antiquated Constitutions; on the Spanish Constitution Considered as a Whole, and on Certain Defects Observable in it' (1821). In On the Liberty of the Press, and Public Discussion and Other Legal and Political Writings for Spain and Portugal (The Collected Works of Jeremy Bentham, UCL Bentham Project edition), edited by Catherine Peace-Watkin and Philip Schofield, 101-8. Oxford: Oxford University Press, 2012.

Bentham, Jeremy. On the Liberty of the Press, and Public Discussion and Other Legal and Political Writings for Spain and Portugal, edited by Catherine Peace-Watkin and Philip Schofield. Oxford: Oxford University Press, 2012.

Bentham, Jeremy. Securities Against Misrule and Other Constitutional Writings for Tripoli and Greece, edited by Philip Schofield. Oxford: Clarendon Press, 1990.

Cain, Peter. 'Bentham and the Development of the British Critique of Colonialism', Utilitas 23/1 (2011): 1-24.

Himmelfarb, Gertrude. The People of the Book: Philosemitism in England, from Cromwell to Churchill. New York and London: Encounter Books, 2011.

Loizides, Antis. 'Taking Their Cue from Plato: James and John Stuart Mill', History of European Ideas 39/1 (2013): 121-40.

Mill, John Stuart. 'Utilitarianism'. In The Collected Works of John Stuart Mill, edited by F. E. L. Priestley (subsequently by John M. Robson), Vol. X, Essays on Ethics, Religion and Society, 203-59. Toronto: University of Toronto Press, 33 vols, 1963-1991.

Pitts, Jennifer. A Turn to Empire: The Rise of Imperial Liberalism in Britain and France. Princeton: Princeton University Press, 2005.

Pitts, Jennifer. “'Great and Distant Crimes”: Empire in Bentham's Thought'. In Jeremy Bentham: Selected Writings, edited by Stephen G. Engelmann, 478-99. New Haven and London: Yale University Press, 2011.

Schofield, Philip. Utility and Democracy: The Political Thought of Jeremy Bentham. Oxford: Oxford University Press, 2006.

Sutcliffe, Adam. Judaism and the Enlightenment. Cambridge: Cambridge University Press, 2003.

Varouxakis, Georgios. 'Guizot's Historical Works and J. S. Mill's Reception of Tocqueville', History of Political Thought 20/2 (1999): 292-312.

Winch, Donald. 'Bentham on Colonies and Empire', Utilitas 9/1 (1997): 147-54.

Winch, Donald. Classical Political Economy and Colonies. London: The London School of Economics and Political Science-G. Bell and Sons, 1965. 


\title{
Happiness and Interests in Politics: A Late-Enlightenment Debate
}

\author{
Emmanuelle de Champs
}

In The Growth of Philosophic Radicalism (Le Radicalisme philosophique, 1904), Élie Halévy presented Bentham's principle of utility as the founding doctrine of the British industrial revolution in contrast to France, where the revolution had taken place not in economics but in politics and had been driven by the rhetoric of rights. In contrast, British classical utilitarianism had chosen interests over rights and freedom. ${ }^{1}$ A century later, John Rawls echoed and revised this seminal opposition when he contrasted two traditions within liberalism, one that used rights to secure liberties, and one that focused on promoting happiness:

The tradition of the liberalism of freedom started at least with the Reformation and gives special priority to certain basic liberties: liberty of conscience and freedom of thought, liberties of persons and the free choice of vocation - liberty from slavery and serfdom - to mention several basic cases. Political liberalism is also a liberalism of freedom. Moreover, it assures all citizens adequate all-purpose means (primary goods) so that they can make intelligent use of the exercise of their freedom. Their happiness, though, is not guaranteed, for that is a matter for citizens themselves. The liberalism of the (classical) Utilitarians - Bentham, James Mill, and Sidgwick - is distinct from the liberalism of freedom. Its first principle is that of the greatest happiness summed over all individuals. If it confirms the liberal freedoms, it is a liberalism of happiness, yet if it doesn't confirm these freedoms, it is not a liberalism at all. Since the basic ideal is that of maximizing happiness, it is a contingent matter whether doing this will secure the basic freedoms. ${ }^{2}$ 
Rawls's choice of Bentham as emblematic of the second option coincides with a long tradition that has classical utilitarianism seeing human beings exclusively as rational agents motivated primarily by self-interest. Historically, against the figure of Bentham, the names of Paine and Condorcet have been put forward to represent the defence of rights and the fight for freedom. ${ }^{3}$ In fact, in a recent contribution to the World Happiness Report, scholars called economists to move away from individualistic Benthamite utilitarianism and to reclaim a fuller tradition of 'public happiness', which they associated with Genovesi in Italy and Condorcet in France. ${ }^{4}$ Such a blunt characterization, which pits an aggregative view of 'the greatest happiness of the greatest number' against a concern for 'public happiness', freedom and rights does not do justice to the work of two influential authors of the late Enlightenment.

By studying the notions of 'happiness' and 'rights' in the writings of Condorcet and Bentham, this paper shows that it is necessary to move beyond the commonly accepted opposition between rights-based discourse and utilitarian reasoning to understand the specificity of late eighteenth-century political thought. Built around the vocabulary of 'happiness' in the early thought of the two authors, the paper first makes a historical case for studying them 'side by side', echoing Fred Rosen's approach to Hume and Smith..$^{5}$ It then locates their respective positions on happiness in the wake of the writings of Claude Adrien Helvétius, who provided an influential framework for the political and moral discussion of happiness in politics in the second half of the eighteenth century. Finally, it examines the positions of Bentham and Condorcet on a series of issues directly related to public happiness in the early years of the French Revolution, up until the end of 1791. In fact, the debate over the political means to happiness cannot be reduced to one that pits utility against rights or the well-being of the majority against that of the individual.

\section{Two philosophers in politics}

Bentham and Condorcet provide rare examples of established Enlightenment thinkers who embraced revolutionary ideas and became, with time, increasingly radical in national politics. Though they were near contemporaries (Condorcet being born five years earlier than Bentham), the two authors' public positions in the 1770s and 1780s differed starkly. A protégé of d'Alembert and a correspondent of Voltaire from the 1770s, Condorcet was at the heart of Enlightenment circles and obtained an 
institutional position at the French Academy of Sciences. From 1774 to 1776, he also gained practical experience of politics during Turgot's tenure as Finance minister (1774-1776). In comparison, the first decades of Bentham's life were spent in relative obscurity. His letter to d'Alembert received only a polite answer and Voltaire never knew that the Englishman had translated one of his philosophical tales. ${ }^{6}$ Only in 1781 , when he obtained the patronage of Lord Shelburne, could Bentham access the kind of inside information on English and French politics that Condorcet had heard directly. Bentham, moreover, remained in the background during Shelburne's eight months in office in 1782-1783.

The 1780s was a formative decade for both men, as they both felt the need for reform in Europe. Bentham embarked on an ambitious scheme to present his ideas to a European audience by producing a work in French while Condorcet worked out the principles of social mathematics. ${ }^{8}$ When over a decade of reforms and revolution began in France in 1788, the events aroused great interest in progressive British political circles such as Shelburne's while in Paris Condorcet took part in the political agitation as a prominent pamphleteer. As early as 1789 , in his draft of an open letter to Mirabeau, Bentham could write of Condorcet as one of the ablest political advisers in the country and asked his French friends to forward him a copy of Le Panoptique to him. ${ }^{9}$ Condorcet mentioned Bentham's name in print only once, even though the Genevan Etienne Dumont, who was conveying Bentham's ideas to France, frequented Condorcet and his wife during the same period..$^{10}$ Their different institutional positions during their formative years thus account for the unbalanced number of cross-references.

The year 1791 marked a divide for Bentham and Condorcet. After the arrest of the royal family at Varennes in June, the political climate changed markedly in France. Condorcet's subsequent defiance towards the king led to his estrangement from the circles that still supported a constitutional monarchy. ${ }^{11}$ From that period, Bentham's interest in French issues waned and he became more critical of the republican turn that Condorcet, among others, had embraced. By 1794, when Condorcet was found dead following his proscription under the Terror, Bentham no longer set his hopes on France. He was in fact at work on Nonsense upon Stilts, an extensive attack on ideas that Condorcet had done his utmost to defend: the existence of natural rights and the necessity to enshrine them in a Declaration.

Despite those differences, their writings of the 1770s and 1780s show that Bentham and Condorcet shared philosophical references and sought to intervene in the same debates in European reform politics. ${ }^{12} \mathrm{On}$ 
the place of happiness in politics, their writings of the pre-revolutionary and revolutionary period introduced themes that continue to shape our understanding of the issue.

\section{Happiness, interests and politics - the legacy of Helvétius}

By the end of the eighteenth century, happiness was well established in political vocabulary. Increasing public happiness should be the object of every philosopher and scientist, as Condorcet told the members of the Academy of Sciences: 'Use the talents and energy Nature has bestowed on you to foster public happiness. Should you receive nothing for your pains but torments and even contempt, should your endeavours be useless, remain certain that you chose right. ${ }^{13}$ As for Bentham, the phrase 'it is the greatest happiness of the greatest number that is the measure of right and wrong' defined a political and philosophical programme that unfolded throughout his life. ${ }^{14}$ The phrase 'the principle of utility', which superseded that of 'the greatest happiness of the greatest number' until the 1810s, is not to be understood as a renunciation of happiness as a political programme, for Bentham consistently defined utility as 'the property of an action to increase happiness.'. ${ }^{15}$

To understand what was at stake in laying down happiness as a political programme in the 1770s and 1780s, it is useful to turn to the writings of Claude Adrien Helvétius. In De l'esprit and De l'homme, he repeatedly and interchangeably appealed to 'utility', 'interest' and 'happiness' to describe the force that motivated human beings to act in private and public affairs. This force was the quest for pleasure and the avoidance of pain. As an anthropological concept, 'interest' referred to how humans apprehended objects external to them, with reason taming the passions in an attempt to improve their condition. ${ }^{16}$ Interest was thus an operating principle in morals and in politics:

In this discourse, one sets out to demonstrate that the same interest which presides over the judgement we pass on actions and makes us consider them as virtuous, vicious, or allowed depending on whether they are useful, harmful or indifferent to the public, presides in the same way over the judgement we pass on ideas. Therefore, in morals as well as in understanding, interest alone dictates all our judgements. One can only perceive the extent of this truth by considering probity and understanding in relation to 1. an individual, 2. a small community, 
3. a nation, 4. the different centuries and different countries, and 5. the universe. ${ }^{17}$

For Helvétius, who built on the core of Epicurean epistemology, interest was not only an axiomatic principle describing the mechanisms of human action, it also laid the foundations for a critical approach that could be applied on different scales, from the individual to 'the universe'.

The sensualist foundations of Helvétius's philosophy were debated in philosophical circles. He had argued that 'every time one bothers to break up the vague sentiment of the love of happiness into its parts, one will find physical pleasure at the bottom of the melting-pot'. ${ }^{18}$ In 1773 , as De l'homme was starting to be read and discussed in French literary circles, Condorcet exchanged a series of letters on the subject with Turgot, who maintained that Helvétius's insistence on the pleasures of the senses made a mockery of private virtue. In his reply, Condorcet did not question the idea that self-interest was a powerful source of action, though he believed Helvétius had failed to recognize the role of sympathy in moral action. ${ }^{19}$ But the desire for reciprocal benevolence was stronger than egotistical self-interest. Throughout his works, and like Sophie de Grouchy who became his wife in 1786 and later translated Smith's Theory of Moral Sentiments into French, Condorcet was keen to distance himself from Helvétius's focus on sensual pleasures and highlighted the force of moral sentiments such as sympathy and pity.

In contrast, Bentham fully accepted the sensualist implications of Helvétius's writings: 'the idea of considering happiness as resolvable into a number of individual pleasures, I took from Helvétius', he maintained. ${ }^{20}$ Contrary to Condorcet, Bentham banished the vocabulary of 'moral sentiment', for he believed that it only thinly concealed arbitrary preferences and personal interests. ${ }^{21}$ But Helvétius and Bentham both pointed out that the definition of self-interest as a source of motivation also encompassed actions usually presented as altruistic or disinterested. Helvétius recognized the joint forces of pity and sympathy as spurs for action: in acting to relieve another human being from pain, people obeyed an impulse that was necessary for their own pleasure and brought them, as a reward, the esteem of others. ${ }^{22}$ Similarly, in An Introduction to the Principles of Morals and Legislation, Bentham made a point of inserting 'the pleasures of sympathy' and those 'of a good name' among the long list of self-regarding pleasures. ${ }^{23}$

Condorcet defended what he called a 'proper sense of interest', one that acknowledged our submission to pain and pleasure but incorporated sympathy for others, the love of virtue and the common good 
and was wary of the power of passions. This did not entail a rejection of interests but a redefinition. 'Is not a mistaken sense of interest the most common cause of actions contrary to the general welfare?' he asked. 'Is not the violence of our passions often the result of habits that we have adopted through miscalculation or of our ignorance of how to restrain them, tame them, deflect them, rule them? ${ }^{24}$ Condorcet's view of interest differed from Bentham's, though they both built on Locke. But both believed that a clear method for assessing and measuring interest could be worked out by reason, thereby allowing people to avoid being lured by false promises. They believed that the vocabulary of interest was an adequate way of understanding the interplay between the individual and political society. In so doing, both distinguished themselves from the position of Rousseau in the Social Contract, according to which, although individual interests played a role in explaining people's wish to enter into a mutual contract, such interests ceased to operate in political society.

For Helvétius, private and public interests could be reconciled and lead to increased happiness for all when a strong and benevolent legislator combined two means. The first was the establishment of good laws backed by sanctions that made obedience in everyone's interest; the second was to promote a clear view of personal interest as coinciding with, not opposed to, public interest, especially through education..$^{25}$ Condorcet embraced this programme in the preparatory manuscripts to his Historical Table of the Progress of the Human Mind. He asked: 'does not the improvement of public laws which follows from the progress of moral and political sciences lead us to identify the common interest of each with the common interest of all? Is not the aim of the social art to destroy this apparent contradiction? ${ }^{26}$ Likewise, Bentham put his faith into the work of a benevolent legislator: 'the business of the government is to promote the happiness of the society, by punishing and rewarding', while also devising ways to improve public debate, public education and morals. ${ }^{27}$

Like Helvétius, Bentham considered individual pains and pleasures as the building blocks of collective happiness:

The happiness of the community is made up of the several happinesses (if one may say so) of the several individuals of which that body is composed - these happinesses are all reducible into such and such pains or evils averted - and such or such pleasures and advantages procured or secured. ${ }^{28}$ 
To calculate whether a measure was good or bad, the legislator should first work out the impact on each individual (attempting to quantify the pleasures according to intensity, duration, proximity and certainty), and then multiply it by the number of persons affected (or its 'extent') - with each person counting as one. ${ }^{29}$ Therefore, in comparing the 'lots of happiness' that some planned measures would create, the legislator should decide in favour of 'the greatest which is partaken of by the greatest number of persons'. ${ }^{30}$ Bentham acknowledged that regarding the precise effects on individuals, the legislator often needed to resort to 'guesswork', but 'as bad as the chance may be which this method gives us of judging right, no other method is there that affords so good an one'. ${ }^{31}$ There is ground for considering Bentham's calculus as an argumentative strategy rather than primarily a mathematical one. ${ }^{32}$

Like Bentham, Condorcet believed that calculus was a valid tool in the hands of the legislator, both to assess specific situations and to evaluate the quality of intended measures. When explaining how social mathematics were to be understood, he had in mind tools that would allow a precise population count and the construction of economic indicators that could serve for mathematical projections. ${ }^{33}$ Would these tools be applicable to the measure of happiness? No: 'being, as a body, an abstract entity, a nation can neither be happy nor unhappy'. ${ }^{34}$ What, then, could the phrase 'the happiness of a nation' mean? While noting that the calculation of averages was a valid tool to be employed by the legislator arbitrating in matters of public policy, ${ }^{35}$ Condorcet excluded it when it came to measuring the happiness of a nation: this would mean 'adopting the maxim ... that the smaller number can legitimately be sacrificed to the greater' ${ }^{36}$

In his early manuscripts, written before he could possibly have read Condorcet's objections, Bentham had also examined the risks of sacrificing the interests of some to maximize those of others when aggregating interests. ${ }^{37}$ Like Helvétius, who believed that forcing people to act against their interest was 'impossible and unnatural', ${ }^{38}$ Bentham understood aggregation as a way to rule out the possibility of private sacrifice:

The question lies not between the Public, on one part, \& himself distinct from the public on the other: but between that part of the public which he is, on the one part, \& the remainder of the persons of which the public is composed, on the other ... . The Salus populi consists not in the sacrificing of private or Public interest, but in the union of both. ${ }^{39}$ 
In this way, Bentham also distanced himself from reason-of-state arguments, making it clear that public interest could not be disconnected from private interests, nor run against them.

If a calculation of averages was to be excluded, which indicators should then be used? Condorcet proposed a list of 'the general means of happiness', which included 'the means of tranquillity and well-being which the land, the laws, industry, the relationships with foreign nations can offer the citizens in general'. ${ }^{40}$ Focusing not on quantities of happiness but on the conditions that made it possible was reminiscent of a similar solution Bentham proposed to bridge the gap between individual and collective happiness in his writings on the civil law of the 1780s:

For a political society to be happy, as much as the human condition allows, four things are needed: subsistence, abundance, equality, safety. The greater the enjoyment of these goods, the greater the sum of happiness, at least that happiness which depends on the laws. Is any of them missing? A proportional share of possible happiness will be missing too. ${ }^{41}$

Condorcet expressed this shift towards indirect means of creating happiness by moving, terminologically, from 'happiness' to 'well-being':

The well-being [of the people], bye the bye, is different from happiness. This well-being consists in not being threatened by poverty, humiliation, oppression. It is this kind of well-being which the government owes the people. It is necessary to happiness but can also be insufficient for it. But it is nature's role to complete it. In improving physics, morals and education, governments may, it is true, correct nature again; but this is not required by justice, only by benevolence. ${ }^{42}$

Likewise, and though Bentham refused to establish such a distinction between well-being and happiness (both being directly derived from the pleasures of the senses), he also distinguished between creating happiness directly, which remained the individual's own responsibility and creating the conditions for happiness, which belonged to the legislator. 'Oh man!' he exclaimed, 'can someone else know what pleases you better than you do?'43

In the 1770 s and 1780s, in different ways, Condorcet and Bentham each developed a theoretical framework for the analysis of political 
issues based on a broader understanding of human nature in political societies, both reinterpreting themes that had been central in the political debates of the late Enlightenment. Who should be in charge of bringing about increased happiness? In the 1770s and early 1780s, at a time when rulers throughout Europe seemed willing to embrace new ideas, both authors had seemed confident that good laws promoted by a monarch could significantly improve the happiness of the people. When they addressed contemporary rulers, Condorcet and Bentham strove to make such a point. 'The happiness of the people,' Condorcet wrote, 'depends more on the enlightenment of their governors than on the shape of political constitutions. ${ }^{44}$ Similar views were to be found in Bentham's writings up until the mid-1780s: 'Let all other laws be good, let the sovereign not oppose their execution, what does it matter in which hands sovereignty is placed?'45

\section{Happiness vs rights? The early years of the French Revolution (1788-1791)}

In the late 1780s, however, Condorcet gradually came to consider that beyond the authority of an enlightened sovereign, popular representation was a necessary condition to improve happiness in a nation. His experience under the Turgot ministry convinced him that representative assemblies had a central role to play in the consolidation of political reform. His increasing interest in the question can be traced from the Essai sur l'application de l'analyse à la probabilité des décisions rendues à la pluralité des voix (1785) through to the Essai sur la constitution et la fonction des assemblées provinciales published in 1788. Compared to this, Bentham's work on political representation before the Revolution was rather limited: for him, the power of the people rested on their collective capacity to set limits to the exercise of sovereign power, not on the direct or even indirect exercise of this power. ${ }^{46}$ It is to be noted, however, that he developed simultaneously an analysis of political powers that made it possible to understand and legitimate various ways of exercising them, regardless of the actual persons, or bodies, that held them. He also addressed the issue of the limits applicable to the exercise of sovereign power. ${ }^{47}$ When the French Estates General were summoned, Bentham did not hesitate to confront the issue of popular representation. In England, he argued, the question could be postponed because public opinion acted as a true check on abuses. In France, on the contrary, the issue had imposed itself and had to be dealt with. ${ }^{48}$ 
Condorcet, like Bentham, couched arguments in favour of political representation in the vocabulary of interests:

A representative assembly cannot be useful if it is not formed in such a way that the wish of the Assembly be in general conformable to the will and the opinion of those which it represents, if the members who compose it do not know the true interest of the nation, and finally if they can be misled by other interests. ${ }^{49}$

However, Condorcet's defiance of unenlightened interests explains why he presented them regularly alongside 'corruption', 'passions' and 'errors', as opposed to the working out of a 'general will'. ${ }^{50}$ He gave representative assemblies two potentially conflicting missions: first, to create the conditions for the expression of a variety of interests; second, to express a general will that included and transcended them. This would be achieved, first, by establishing 'a good method for elections', ${ }^{51}$ the details of which were laid out in mathematical terms in 1785 and worked out practically in 1788, through the ranking of candidates on lists. ${ }^{52}$ This went together with a reshaping of electoral districts according to population: the division of the country would allow the equal weight of local interests. ${ }^{53}$ The second mission would be fulfilled by offering deputies a forum for 'expressing their wills' and 'deliberating on their interests'. ${ }^{54}$ Deliberation on the proposed legislation, for which Condorcet laid out a strict procedure, could counteract 'the balance of opposing passions, of contrary interests, of fighting prejudices'. ${ }^{55}$ Condorcet's search for 'truth' in political decisions did not entail the exclusion of interests from the realm of politics. ${ }^{56}$

Bentham's views in the early years of the French Revolution also included an original attempt to associate the representation of individual interests with the working out of a general decision that expressed and transcended them. The role of an elected assembly was 'to be representative of the people, to try to consult its wills or its interests'. Like Condorcet, Bentham drew up electoral districts in relation to the population. But his view of the role of an assembly was not simply to process individual interests into a national one through aggregation or majority vote. The aim was to ally 'véracité' (i.e. decisions conformable to truth, namely the general interest of the nation) with 'fidélité' (i.e. fidelity to the will and interests expressed by the people). To achieve this, he proposed an original solution, placing individual deputies under the direct control of their electors (who could dismiss them at any time during their oneyear mandate) while asking them to swear 'an oath to prefer the general 
interest to the particular interest, real or imagined, of [their] constituents'. ${ }^{57}$ These seemingly contradictory commitments could be reconciled only by giving deliberation in the assembly a central role. In Political Tactics, Bentham devised strict rules for such deliberation, so that all opinions could be heard and discussed before any vote. ${ }^{58}$ In their speeches, the deputies were bound by nothing but their desire to work out the general interest. After debates held in public and publicized through the press, the deputies were to go back to their constituencies to take the opinion of the people: Bentham hoped that, enlightened by the quality of the debates in the assembly, the deputies would then be ready to revise their original view of their own interest in the light of that of the nation taken together and modify their mandate accordingly. ${ }^{59}$

Condorcet's and Bentham's views on how to combine the expression of interests with the creation of a collective will led them to draw similar conclusions in two other respects: they both justified the inclusion of women among electors, and they refused a bicameral system. ${ }^{60}$ However, major differences of focus persisted, the main one being Condorcet's belief that deputies to a National Assembly should be elected by a two-tiered system (citizens would vote for electors, who would in turn vote for deputies), something that was absent in Bentham. ${ }^{61}$ Both were anxious to check the influence of an unenlightened electorate through a property qualification. But while Condorcet maintained this up until the end of 1791, Bentham changed his views earlier. Like Condorcet, he originally thought that only property owners could be said to have an interest in the security of property, but in the autumn of 1789, he wanted a vote for 'every French citizen, male or female, being of full age, of sound mind, and able to read'. ${ }^{62}$

These extended discussions of the interplay of interests in representative assemblies were also connected to a changing understanding of the place of happiness in politics, especially of the connection between happiness and rights. The preamble to the French Declaration of the Rights of Man and of the Citizen, drafted and adopted in the summer of 1789 , stated that 'the happiness of all' was the final aim of a declaration based on 'the natural, inalienable and sacred rights of man'. ${ }^{63}$ Happiness was the final aim of political association; it was within reach of individuals and of nations when they followed the prescriptions of natural law and natural reason. These views were widely shared, including by materialists such as Helvétius. As Ann Thomson recently explained, they did not exclude appeals to natural law. As they strove 'to reconcile individual happiness and social utility', they held that 'the pursuit of happiness was the basis of natural law and should also be the basis of civil laws'. ${ }^{64}$ Bentham and Condorcet provide good examples of the modifications 
undergone by the discourse on rights by the end of the eighteenth century in enlightened circles.

For Bentham, alongside the rest of 'the works of Grotius, Pufendorf and Burlamaqui', ${ }^{65}$ a right to the pursuit of happiness was nonsensical. Commenting on the American Declaration of Independence in 1776, he had written: 'If the right of pursuit of happiness is a right unalienable, why (how) are thieves restrained from pursuing it by theft, murderers by murder, and rebels by rebellion?' In setting out this right, the Americans 'have out done the utmost extravagance of all former fanatics' ${ }^{66}$ In the years 1789 to 1791, Bentham examined and commented on several projects for a Declaration of Rights drafted in France. No declaration could act as a substitute for the only test of the legitimacy of a law: the will of the legislator. Substituting vague ideas of 'the people's pleasure' would only foster chaos. Methodologically speaking, starting from first principles was a mistake: only after individual laws had been assessed could one decide whether they were good or bad: 'no law is good that does not add more to the general mass of felicity than it takes from it - No law ought to be made that does not add more to the general mass of felicity than it takes from it'. ${ }^{67}$ It was not by holding proposed legislation up to any superior and abstract legal standard that anyone could interpret as they wished that its desirability should be assessed, but by conducting a careful analysis of its expected consequences.

Condorcet never questioned the idea that happiness was the main object towards which legislators and individuals should strive. Indeed, the roots of this lay in the reasons for political association: 'men have no other motives for their action than to avoid pain and look for happiness'. ${ }^{68}$ Their decision to unite in political society derived from this objective and securing 'the free enjoyment of natural rights' was the first general condition for happiness. ${ }^{69}$ Happiness and rights were therefore intrinsically linked because they derived from the nature of man and the genesis of political association. These natural rights were ' 1 . personal security and liberty. 2. security and liberty for one's properties. 3. equality'. ${ }^{70}$ This did not include any right to happiness.

Bentham and Condorcet both considered the rhetorical force of declarations of rights and drew diverging conclusions. Condorcet believed that a declaration of rights would pacify public opinion and increase the people's trust in legislators:

a Declaration of rights has a further advantage in that it ensures general tranquillity. Armed with such a shield, a nation ceases to 
fret about every innovation, it has no pretext to take offence from those which are useful, it is not so easily misled by the defenders of abuses towards which the laws in question are directed, it does not confuse privileges that directly encroach on their rights with rights themselves, nor supports institutions which are directly opposed to its interests. ... a declaration of rights is both the guardian of tranquillity and that of public liberty. ${ }^{71}$

In this, he followed an insight that his mentor Turgot had developed during their correspondence on Helvétius's principles. Turgot had mentioned the effects of political principles on the behaviour of individuals and concluded, against the discourse of interest, that only appeals to rights were able to ensure public safety:

When one wants to attack intolerance and despotism, one must first ground one's ideas upon exact ones, for inquisitors have an interest in being intolerant, and viziers and sub-viziers have an interest in preserving the abuses of government. Because they are the strongest, indiscriminately sounding the alarm bell against them means proving them right. I hate despotism as much as anyone else, but it will not be brought down by declamations, only by demonstrating the rights of man. ${ }^{72}$

Bentham also valued public order, but he believed that appeals to rights inflamed the passions, especially violent ones. Declarations of rights were, according to him, tools for manipulating crowds. Imposing utility meant placing the language of reason above that of passion. Much of his argument against rights-based discourse was therefore grounded in an analysis of their rhetorical appeal. Indeed, in 1789 and 1790, he was still willing to believe that rights and utility could be reconciled, if rhetorical forms were altered:

Change the language and instead of can not put ought no, the case is widely different. The moderate expression of opinion and will intimated by this phrase leads naturally to the inquiry after a reason, and this reason, if there be any at bottom that deserves the name, is always a proposition of fact relative to the question of utility. Such a law ought not to be established, because it is not consistent with the general welfare: its tendency is not to add to the general stock of happiness. ${ }^{73}$ 
Appealing to rights was no different from other types of arguments; it should also be weighed according to utility. In shifting the debate from the existence of natural rights to their efficiency, both Condorcet and Bentham can be seen as heirs to a protracted debate within eighteenthcentury legal and political thought, one that cannot be summed up to an opposition between a priori rights and consequentialist reasoning. ${ }^{74}$

\section{Conclusion}

In many ways, the issues addressed by Condorcet and Bentham until 1791 laid the foundations of recurring debates in early liberal circles. Both authors' pre-revolutionary writings were indeed collected and printed again in the late 1790s and 1800s. Together, they were read by the Idéologues, Benjamin Constant, Madame de Staël, Tocqueville and Jean-Baptiste Say, in post-revolutionary France. ${ }^{75}$ In England, a young utilitarian such as John Stuart Mill presented Condorcet's Life of Turgot as a sort of antidote to Benthamite sectarianism - his own brand of utilitarianism appearing therefore as a kind of synthesis of the two philosophies. ${ }^{76}$ The following generation, both in France and in Britain, provided editions of their works simultaneously: Bentham's Complete Works were published by John Bowring in Edinburgh up to 1843, while the final volume of Condorcet's CEuvres, under the editorship of Arthur O'Connor Condorcet's son-in-law, who, Bentham boasted, had wished to become one of his own 'disciple[s]' - came out in Paris in 1847. ${ }^{77}$

Indeed, their political thought has more in common than has usually been acknowledged. Not only did they start from comparable anthropological foundations, they also recognized a common goal for individual and political achievement, that of happiness, understood as a secular pursuit. Where they differed was not, substantially, in their definition of happiness, nor in the status they ascribed to the individual. In the way they imagined the political and social structures giving rise to maximum happiness, the similarities between their proposals are striking - such are their parallel, if unsynchronized, moves towards democratic and republican government. Many of their conclusions, including a belief in political equality, a view that the state's duty is to secure the conditions for the security and the well-being of individuals, the necessity of fostering a free public opinion and of trusting in the gradual enlightenment of the people, were also similar and would not have surprised readers of Helvétius.

However, the French Revolution deeply polarized contemporary political thought. After that, it is impossible to ignore the divide 
between two types of arguments, one deriving from natural rights (after Condorcet) and the other from utility (after Bentham). As this paper has made clear, the choice of rights over utility (or the other way around) can be understood as a conscious strategy to educate public opinion and to set up a rationale that legitimates reform. There is no doubt that this element has indeed been central in ensuring the success of the rhetoric of rights. It is, however, insufficient to distinguish between two types of liberalism: the two approaches developed historically together and in constant dialogue with one another.

\section{Notes}

1. Élie Halévy, The Growth of Philosophic Radicalism (London: Faber \& Faber, 1952), xvi-xviii. This article is part of a project that has received funding from the European Union's Horizon 2020 research and innovation programme under the Marie Skłodowska-Curie grant agreement No. 665958.

2. John Rawls, Lectures on the History of Moral Philosophy, ed. Barbara Herman (Cambridge, Mass.: Harvard University Press, 2000), 336.

3. Jean-Daniel Boyer and Charlotte Le Chapelain, 'Smith and Condorcet on Instruction and the Rawlsian Opposition', in Freedom and Happiness in Economic Thought and Philosophy: From Clash to Reconciliation, ed. Ragip Ege and Herrade Igersheim (London: Routledge, 2011), $52-66$.

4. Luigino Bruni and Stefano Zamagni, 'The Challenges of Public Happiness: An HistoricalMethodological Reconstruction', in World Happiness Report 2016, Special Rome Edition (Vol. II), eds. Jeffrey Sachs, Leonardo Becchetti and Anthony Annett (New York: Sustainable Development Solutions Network, 2016), 66-86.

5. Frederick Rosen, Classical Utilitarianism from Hume to Mill (London: Routledge, 2003), 83.

6. Emmanuelle de Champs, Enlightenment and Utility. Bentham in France, Bentham in French (Cambridge: Cambridge University Press, 2015), 19-55.

7. See the long letter in which Bentham repeats conversations in Shelburne's salon about the fall of the Turgot ministry, The Correspondence of Jeremy Bentham, Vol. 3, 1781-1788, ed. Ian R. Christie (London: Athlone Press, 1971), 59-67. The English translation of Life of Turgot (1787) was sponsored by Shelburne. Bentham received it from him in 1789; see The Correspondence of Jeremy Bentham, Vol. 4, 1788-1793, ed. A. T. Milne (London: Athlone Press, 1981), 73.

8. de Champs, Enlightenment and Utility, 55-92; Keith Michael Baker, Condorcet: From Natural Philosophy to Social Mathematics (Chicago: University of Chicago Press, 1975), 197-263.

9. Jeremy Bentham, Rights, Representation, and Reform: Nonsense upon Stilts and Other Writings on the French Revolution, ed. Philip Schofield, Catherine Pease-Watkin and Cyprian Blamires (Oxford: Oxford University Press, 2002), 95, 378; Bentham, Correspondence, Vol. 4, 50n. Condorcet does not seem to have acknowledged reception of the work; see Bentham, Correspondence, Vol. 4, 352 and note For a later reference, see Bentham, The Book of Fallacies, ed. Philip Schofield (Oxford: Oxford University Press, 2015), 215.

10. Nicolas de Condorcet, 'Révision des travaux de la Première Législature', in CEuvres de Condorcet, eds. Arthur Condorcet O'Connor and M. F. Arago (Paris: Firmin Didot Frères, 1847), X, 379; for Dumont's contacts with the Condorcets, see Etienne Dumont, Souvenirs sur Mirabeau et sur les deux premières assemblées législatives (Paris: Charles Gosselin, Hector Bossange, 1832).

11. The issue of Condorcet's 'conversion' to republicanism has long been debated. For a recent assessment, see Alberto Petix, 'Vers le républicanisme: l'évolution de la pensée politique de Condorcet à la lumière de sa correspondance inédite avec Brissot', in La Correspondance de Condorcet. Documents inédits, nouveaux éclairages. Engagements politiques, 1775-1792, eds. Nicolas Rieucau, Annie Chassagne and Christian Gilain (Ferney-Voltaire: Centre international d'études du XVIIIe siècle, 2014), 63-81. 
12. For a comparison of their writings on penal reform, see Emmanuelle de Champs, 'Réforme juridique, réforme politique, le jury populaire chez Beccaria, Condorcet et Bentham', in Le moment Beccaria. Les origines intellectuelles du droit pénal modern (1764-1810), eds. Philippe Audegean and Luigi Delia (Oxford: Voltaire Foundation, 2018), 133-42.

13. Condorcet, OEuvres III, 564.

14. Jeremy Bentham, A Comment on the Commentaries and A Fragment on Government, eds. James H. Burns and Herbert L. A. Hart (London: Athlone Press, 1977), 393; for the origin of this phrase, see James H. Burns, 'Happiness and Utility: Jeremy Bentham's Equation', Utilitas 17/1 (2005): 46-61.

15. Jeremy Bentham, Preparatory Principles, eds. Douglas G. Long and Philip Schofield (Oxford: Oxford University Press, 2016), 130. For early explorations of happiness in manuscripts, see for instance Bentham Papers, University College London 27, f. 22-40 (hereafter UC, box, folio).

16. Albert O. Hirschman, The Passions and the Interests. Political Arguments for Capitalism before Its Triumph (Princeton: Princeton University Press, 1977).

17. Claude Adrien Helvétius, De l'esprit, eds. Gerhard Stenger and Jonas Steffen (Paris: Champion, 2016), 36-7. Italics in original.

18. Helvétius, De l'esprit, 262.

19. Nicolas de Condorcet and Anne-Robert-Jacques Turgot, Correspondance inédite de Condorcet et de Turgot: 1770-1779, ed. Charles Henry (Geneva: Slatkine Reprints, 1970), 140-55.

20. UC 27, 34. For Bentham's debt to Helvétius, see Douglas Long, "Utility" and the "Utility Principle”: Hume, Smith, Bentham, Mill', Utilitas 2 (1990): 12-39; Frederick Rosen, 'Helvétius, the Scottish Enlightenment, and Bentham's Idea of Utility', in Classical Utilitarianism, 82-96; de Champs, Enlightenment and Utility, 42-5.

21. Jeremy Bentham, An Introduction to the Principles of Morals and Legislation, eds. James H. Burns, Herbert L. A. Hart and Frederick Rosen (Oxford: Clarendon Press, 1996), 17-33; Frederick Rosen, 'Utility and Justice: Epicurus and the Epicurean Tradition', in Classical Utilitarianism, 15-28. On this topic, see Chapter 4 in this volume by James Moore.

22. Helvétius, De l'esprit, 84-5.

23. Bentham, An Introduction, 42-6.

24. Nicolas de Condorcet, Tableau historique des progrès de l'esprit humain. Projets, esquisse, fragments et notes (1772-1793), ed. Groupe Condorcet (Paris: INED, 2004), 813-14; Baker, Condorcet, 282. From Constant to Tocqueville, the phrase 'intérêt bien entendu' was to have a long legacy in French political thought.

25. Sophie Audidière, 'Helvétius: Introduction', in Matérialistes français du XVIIIe siècle, eds. Sophie Audidière et al. (Paris: Presses Universitaires de France, 2006), 193-214.

26. Condorcet, Tableau historique, 449.

27. Bentham, An Introduction, 74; Bentham's interest in education developed much later and he never envisaged any scheme on the scale of Condorcet's national system of public education; see Jeremy Bentham, Chrestomathia, eds. M. J. Smith and W. H. Burston (Oxford: Clarendon Press, 1983). On improving public education and morals, see 'Indirect Legislation', in Jeremy Bentham, Selected Writings, ed. Stephen G. Engelmann (New Haven and London: Yale University Press, 2011), 152-214.

28. Bentham, Correspondence, Vol. 3, 28-9. See Helvétius, De l'homme, ed. Gerhard Stenger et al. (Paris: Champion, 2011), 387.

29. Bentham, An Introduction, 38-41.

30. UC 27, f. 23 and 29.

31. Bentham, Preparatory Principles, 327.

32. Bentham, An Introduction, 40; for recent studies on calculation in Bentham's works, see JeanPierre Cléro, 'Le calcul benthamien des plaisirs et des peines', Archives de Philosophie 78/2 (2015): 229-58; Michael Quinn, 'Bentham on Mensuration: Calculation and Moral Reasoning', Utilitas 26/1 (2014): 61-104.

33. Nicolas de Condorcet, 'Tableau général de la science qui a pour objet l'application du calcul aux sciences politiques et morales', in CEuvres de Condorcet, 539-73; on Condorcet's method, see Pierre Crépel and Jean-Nicolas Rieucau, 'Condorcet's Social Mathematics. A Few Tables', Social Choice and Welfare 25/2/3 (2003): 243-85.

34. Nicolas de Condorcet, 'De l'influence de la Révolution d'Amérique sur l'Europe', in OEuvres VIII, 4-5.

35. Condorcet, 'Tableau général'. 
36. Condorcet, 'De l'influence', 5.

37. Frederick Rosen, 'Individual Sacrifice and the Greatest Happiness: Bentham on Utility and Rights', Utilitas, 10/2 (1998) 129-43.

38. Helvétius, De l'homme, 448.

39. UC 70(a), f. 17.

40. Condorcet, 'De l'influence', 4-5.

41. UC 33, f. 102 (original in French). On this topic, see Paul J. Kelly, Utilitarianism and Distributive Justice: Jeremy Bentham and the Civil Law (Oxford: Clarendon Press, 1990).

42. Nicolas de Condorcet, 'Réflexions sur le commerce des blés', in CEuvres, XI, 155n.

43. UC 100, f. 49.

44. Petix, 'Vers le républicanisme', 66.

45. UC 170, f. 201.

46. The 'popular sanction' was described as 'the grand préservatif to abuses of power; see UC 170, f. 199. In that period, Bentham placed more emphasis on structuring a free public opinion through a free press and free speech than on constitutional reform.

47. UC 30, f. 73-80; Jeremy Bentham, Of the Limits of the Penal Branch of Jurisprudence, ed. Philip Schofield (Oxford: Oxford University Press, 2010).

48. Bentham, Rights, Representation, and Reform, 7. The comparison of Bentham's and Condorcet's voting systems has attracted attention; see Marco E. L. Guidi, 'Jeremy Bentham, the French Revolution, and the Political Economy of Representation (1788 to 1789)', European Journal of the History of Economic Thought 17/4 (2010): 579-605; Jon Elster, Securities against Misrule: Juries, Assemblies, Elections (Cambridge University Press, 2013).

49. Nicolas de Condorcet, Vie de M. Turgot (London, 1786), 112.

50. Nicolas de Condorcet, 'Lettres d'un bourgeois de New-Haven à un citoyen de Virginie sur l'inutilité de partager le pouvoir législatif en plusieurs corps', in CEuvres, IX, 5.

51. Nicolas de Condorcet, 'Sur la forme des élections', in OEuvres, IX, 289.

52. Nicolas de Condorcet, Essai sur l'application de l'analyse à la probabilité des décisions rendues à la pluralité des voix (Paris: Imprimerie Royale, 1785); Essai sur la constitution et la fonction des assemblées provinciales, in OEuvres, VIII, 115-659.

53. Condorcet, 'Lettres d'un bourgeois de New Haven', 22.

54. Nicolas de Condorcet, 'Réflexions sur les pouvoirs et instructions à donner par les provinces à leurs députés aux Etats-Généraux', in OEuvres, IX, 272.

55. Condorcet, 'Sur la forme des élections', 288.

56. David Williams, Condorcet and Modernity (Cambridge: Cambridge University Press, 2004), 195-224.

57. Bentham, Rights, Representation, and Reform, 21, 243, 35, 51.

58. Jeremy Bentham, Political Tactics, eds. Michael James, Cyprian Blamires and Catherine Pease-Watkin (Oxford: Clarendon Press, 1999).

59. Bentham, Rights, Representation, and Reform, 51-3; Emmanuelle de Champs, 'La déontologie politique' (Geneva: Droz, 2008), 182-91; Peter Niesen, 'Une petite mappemonde du chaos: la délibération parlementaire chez Bentham et Dumont', in Bentham et la France. Fortune et infortunes de l'utilitarisme, eds. Emmanuelle de Champs and Jean-Pierre Cléro (Oxford: SVEC, 2009), 129-41.

60. On women's suffrage, see Condorcet, 'De l'admission des femmes au droit de cité', in OEuvres, X, 119-130; Bentham, Rights, Representation, and Reform, 246-48. Though their reasonings are contemporary and strikingly similar, there is a significant difference between publishing them, as Condorcet did, and keeping them buried in manuscripts as Bentham did (he also later excluded women from the electorate in Constitutional Code).

61. Condorcet, 'Sur la forme des élections', 290.

62. Compare Bentham, Rights, Representation, and Reform, 81 and 231; Condorcet, 'Sur la forme des élections', 290.

63. 'Déclaration des droits de l'homme et du citoyen de 1789', in Stéphane Rials, La déclaration des droits de l'homme et du citoyen (Paris: Hachette, 1989), 21.

64. Ann Thomson, 'French Eighteenth-Century Materialists and Natural Law', History of European Ideas 42/2 (2016): 243-55, 255.

65. Bentham, An Introduction, 298n.

66. The Correspondence of Jeremy Bentham, Vol. 1, 1752-1776, ed. T. L. S. Sprigge (London: Athlone Press, 1968), 343-4.

67. Bentham, Rights, Representation, and Reform, 183, 185. 
68. Condorcet, 'Réflexions sur les pouvoirs', 270.

69. Condorcet, 'De l'influence', 5.

70. Nicolas de Condorcet, 'Idées sur le despotisme, à l'usage de ceux qui prononcent ce mot sans l'entendre', in OEuvres, IX, 166. Condorcet explicitly excluded equality of property: 'inequality of wealth is not contrary to natural rights, it is a necessary consequence of the right to property'.

71. Condorcet, 'Idées sur le despotisme', 172-73.

72. Condorcet and Turgot, Correspondance inédite, 145. A similar argument was later used by Constant: 'Tell a man: you have the right not to be put to death or despoiled arbitrarily: you give him a much greater feeling of security and certainty than if you tell him: it is not useful that you be put to death or despoiled arbitrarily. ... By using the language of right, you present an idea that is independent of all calculation. By using the language of utility, you invite to question the thing itself by submitting it to further verification.' See de Champs, Enlightenment and Utility, 190.

73. Bentham, Rights, Representation, and Reform, 189. See also in the same work, 'What one calls natural law' can have no other meaning than 'the clearest dictates of utility', 18. In the mid1790 s, when he wrote Nonsense upon Stilts, he abandoned this conciliatory attitude and highlighted the 'anarchical' consequences of all declarations of rights.

74. For a similar insight from a different perspective, see Knud Haakonssen, 'Protestant Natural Law Theory. A General Interpretation', in New Essays on the History of Autonomy. A Collection Honoring J. B. Schneewind, eds. Natalie Brender and Larry Krasnoff (Cambridge: Cambridge University Press, 2004), 92-109.

75. de Champs, Enlightenment and Utility, 161-99.

76. John Stuart Mill, Autobiography and Literary Essays, eds. John Robson and Jack Stillinger (Toronto: University of Toronto Press, 1981), 115-16.

77. Jeremy Bentham, The Works of Jeremy Bentham, ed. John Bowring (Edinburgh: William Tait, 1843); Condorcet, CEuvres (1847). In the 1820s, Bentham wrote to Jean-Baptiste Say that he had been shown a letter 'the purport of which was that [Arthur O'Connor] was in a way to salvation, as numbering himself among my disciples: though it does not appear that as yet "he has left all to follow me"'. Bibliothèque Nationale de France, Jean-Baptiste Say manuscripts, NAF 26252, f.69-71 (9 September 1828) .

\section{Bibliography}

Audidière, Sophie. 'Helvétius: Introduction'. In Matérialistes Français du XVIIIe siècle, edited by Sophie Audidière, Jean-Claude Bourdin, Jean-Marie Lardic, Francine Markovits and Yves Charles Zarka, 193-214. Paris: Presses Universitaires de France, 2006.

Baker, Keith Michael. Condorcet: From Natural Philosophy to Social Mathematics. Chicago: University of Chicago Press, 1975.

Bentham, Jeremy. A Comment on the Commentaries and A Fragment on Government. Edited by J. H. Burns and H. L. A. Hart. London: Athlone Press, 1977.

Bentham, Jeremy. An Introduction to the Principles of Morals and Legislation. Edited by James H. Burns, H. L. A. Hart and Frederick Rosen. Oxford: Clarendon Press, 1996.

Bentham, Jeremy. Chrestomathia. Edited by M. J. Smith and W. H. Burston. Oxford: Clarendon Press, 1983.

Bentham, Jeremy. Of the Limits of the Penal Branch of Jurisprudence. Edited by Philip Schofield. Oxford: Oxford University Press, 2010.

Bentham, Jeremy. Political Tactics. Edited by Michael James, Cyprian Blamires and Catherine Pease-Watkin. Oxford: Clarendon Press, 1999.

Bentham, Jeremy. Preparatory Principles. Edited by Douglas G. Long and Philip Schofield. Oxford: Oxford University Press, 2016.

Bentham, Jeremy. Rights, Representation, and Reform: Nonsense upon Stilts and Other Writings on the French Revolution. Edited by Philip Schofield, Catherine Pease-Watkin and Cyprian Blamires. Oxford: Oxford University Press, 2002.

Bentham, Jeremy. Selected Writings. Edited by Stephen G. Engelmann. New Haven and London: Yale University Press, 2011.

Bentham, Jeremy. The Book of Fallacies. Edited by Philip Schofield. Oxford: Oxford University Press, 2015. 
Bentham, Jeremy. The Correspondence of Jeremy Bentham, Vol. 1, 1752-1776. Edited by T. L. S. Sprigge. London: Athlone Press, 1968.

Bentham, Jeremy. The Correspondence of Jeremy Bentham, Vol. 3, 1781-1788. Edited by Ian R. Christie. London: Athlone Press, 1971.

Bentham, Jeremy. The Correspondence of Jeremy Bentham, Vol. 4, 1788-1793. Edited by A. T. Milne. London: Athlone Press, 1981.

Bentham, Jeremy. The Works of Jeremy Bentham. Edited by John Bowring. Edinburgh: William Tait, 1843.

Boyer, Jean-Daniel and Le Chapelain, Charlotte. 'Smith and Condorcet on Instruction and the Rawlsian Opposition'. In Freedom and Happiness in Economic Thought and Philosophy: From Clash to Reconciliation, edited by Ragip Ege and Herrade Igersheim, 52-66. London: Routledge, 2011.

Bruni, Luigino and Zamagni, Stefano. 'The Challenges of Public Happiness: An Historical-Methodological Reconstruction'. In World Happiness Report 2016, Special Rome Edition (Vol. II), edited by Jeffrey Sachs, Leonardo Becchetti and Anthony Annett, 66-86. New York: Sustainable Development Solutions Network, 2016.

Burns, James H. 'Happiness and Utility: Jeremy Bentham's Equation', Utilitas 17/1 (2005): 46-61.

Champs, Emmanuelle de. Enlightenment and Utility. Bentham in France, Bentham in French. Cambridge: Cambridge University Press, 2015.

Champs, Emmanuelle de. 'La déontologie politique' Ou La pensée constitutionnelle de Jeremy Bentham. Geneva: Droz, 2008.

Champs, Emmanuelle de. 'Réforme juridique, réforme politique. Le jury populaire chez Beccaria, Condorcet et Bentham'. In Le moment Beccaria. Les origines intellectuelles du droit pénal moderne (1764-1810), edited by Philippe Audegean and Luigi Delia, 133-42. Oxford: Voltaire Foundation, 2018.

Cléro, Jean-Pierre. 'Le calcul benthamien des plaisirs et des peines', Archives de Philosophie 78/2 (2015): 229-58.

Condorcet, Jean Antoine Nicolas de Caritat de. Essai sur l'application de l'analyse à la probabilité des décisions rendues à la pluralité des voix. Paris: Imprimerie Royale, 1785.

Condorcet, Jean Antoine Nicolas de Caritat de. OEuvres de Condorcet. Edited by Arthur Condorcet O'Connor and M. F. Arago. Paris: Firmin Didot Frères, 1847.

Condorcet, Jean Antoine Nicolas de Caritat de. 'Tableau général de la science qui a pour objet l'application du calcul aux sciences politiques et morales'. In CEuvres de Condorcet, I, 539-73.

Condorcet, Jean Antoine Nicolas de Caritat de. Tableau historique des progrès de l'esprit humain. Projets, esquisse, fragments et notes (1772-1793). Edited by Groupe Condorcet. Paris: INED, 2004.

Condorcet, Jean Antoine Nicolas de Caritat de. Vie de M. Turgot. London, 1786.

Condorcet, Jean Antoine Nicolas de and Turgot, Anne-Robert-Jacques. Correspondance inédite de Condorcet et de Turgot: 1770-1779. Edited by Charles Henry. Geneva: Slatkine Reprints, 1970.

Crépel, Pierre and Rieucau, Jean-Nicolas. 'Condorcet's Social Mathematics. A Few Tables', Social Choice and Welfare 25/2/3 (2003): 243-85.

Dumont, Etienne. Souvenirs sur Mirabeau et sur les deux premières assemblées législatives. Paris: Charles Gosselin, Hector Bossange, 1832.

Elster, Jon. Securities against Misrule: Juries, Assemblies, Elections. Cambridge: Cambridge University Press, 2013.

Guidi, Marco E. L. 'Jeremy Bentham, the French Revolution, and the Political Economy of Representation (1788 to 1789)', European Journal of the History of Economic Thought 17/4 (2010): 579-605.

Haakonssen, Knud. 'Protestant Natural Law Theory. A General Interpretation'. In New Essays on the History of Autonomy. A Collection Honoring J. B. Schneewind, edited by Natalie Brender and Larry Krasnoff, 92-109. Cambridge: Cambridge University Press, 2004.

Halévy, Elie. The Growth of Philosophic Radicalism. London: Faber \& Faber, 1952.

Helvétius, Claude Adrien. De l'esprit, 36-7. Edited by Gerhard Stenger and Jonas Steffen. Paris: Champion, 2016.

Helvétius, Claude Adrien. De l'homme. Edited by Gerhard Stenger, David Smith, Harold Brathwaite and Jonas Steffen. Paris: Champion, 2011.

Hirschman, Albert O. The Passions and the Interests. Political Arguments for Capitalism before Its Triumph. Princeton: Princeton University Press, 1977.

Kelly, Paul J. Utilitarianism and Distributive Justice: Jeremy Bentham and the Civil Law. Oxford: Clarendon Press, 1990. 
Long, Douglas. "Utility" and the "Utility Principle": Hume, Smith, Bentham, Mill', Utilitas 2 (1990): 12-39.

Mill, John Stuart, Autobiography and Literary Essays. Edited by John Robson and Jack Stillinger. Toronto: University of Toronto Press, 1981.

Niesen, Peter. 'Une petite mappemonde du chaos: la délibération parlementaire chez Bentham et Dumont'. In Bentham et La France. Fortune et Infortunes de l'utilitarisme, edited by Emmanuelle de Champs and Jean-Pierre Cléro. Oxford: SVEC, 2009.

Petix, Calogero Alberto. 'Vers le républicanisme: l'évolution de la pensée politique de Condorcet à la lumière de sa correspondance inédite avec Brissot'. In La Correspondance de Condorcet. Documents inédits, nouveaux éclairages. Engagements politiques, 1775-1792, edited by Nicolas Rieucau, Annie Chassagne and Christian Gilain, 63-81. Ferney-Voltaire: Centre international d'études du XVIIIe siècle, 2014.

Quinn, Michael. 'Bentham on Mensuration: Calculation and Moral Reasoning', Utilitas 26/1 (2014): 61-104.

Rawls, John. Lectures on the History of Moral Philosophy. Edited by Barbara Herman. Cambridge, Mass.: Harvard University Press, 2000.

Rials, Stéphane (ed.). La Déclaration des droits de l'homme et du citoyen. Paris: Hachette, 1989.

Rosen, Frederick. Classical Utilitarianism from Hume to Mill. London: Routledge, 2003.

Rosen, Frederick. 'Individual Sacrifice and the Greatest Happiness: Bentham on Utility and Rights', Utilitas 10/2 (1998): 129-43.

Thomson, Ann. 'French Eighteenth-Century Materialists and Natural Law', History of European Ideas 42/2 (2016): 243-55.

Williams, David. Condorcet and Modernity. Cambridge: Cambridge University Press, 2004. 


\section{Jeremy Bentham and the Spanish Constitution of 1812}

Philip Schofield

An essay on Jeremy Bentham's assessment of the Spanish Constitution of 1812 is particularly apt as a contribution to this volume in honour of Frederick Rosen. In his role as General Editor of the new authoritative edition of The Collected Works of Jeremy Bentham, Fred devoted a great deal of time and energy to encouraging the study of Bentham and John Stuart Mill in Spain and Portugal, and in particular in supporting the work of the late Professor Esperanza Guisán. The establishment of the Ibero-American Society for Utilitarian Studies was just one of the developments that Fred inspired. Such an essay also reflects Fred's interest in Bentham's constitutional theory and his influential rejection of the received view of Bentham as an authoritarian democrat, in favour of an interpretation that emphasized his credentials as a founder of modern liberalism. Indeed, our contemporary usage of the term 'liberal' emerged from the dispute between liberales and serviles that marked the period in Spanish history with which the present essay is concerned. I should add, moreover, that the work I undertook on some of the primary sources drawn on for this essay, and which appear in the volume entitled Colonies, Commerce, and Constitutional Law, ${ }^{1}$ was undertaken under Fred's general editorship and funded by an award from the Economic and Social Research Council under which Fred was Principal Investigator. Speaking on behalf of those of us - as yet far too few - who take a serious interest in Bentham's constitutional theory, I take this opportunity to acknowledge our immense and profound debt to Fred's pioneering scholarship. 
The Spanish Constitution promulgated by the Cortes of Cádiz on 19 March 1812 had been drawn up while much of Spain was occupied by French forces, and while the legitimate Bourbon monarch, Ferdinand VII, ${ }^{2}$ lived in exile at Valençay, in the South of France. Having returned to Spain in March 1814 following the expulsion of the French, Ferdinand VII, by a decree of 4 May 1814, declared all acts of the Cortes null and void, abolished the Constitution, and thereby restored royal absolutism. ${ }^{3}$ In December 1819, an expeditionary force destined for South America was assembled at La Isla de Leon, near Cádiz. On 1 January 1820, Rafael del Riego, an officer in this army, declared in favour of the Constitution of 1812. Such was the dissatisfaction with Ferdinand VII's personal rule that the subsequent revolt met with little opposition. On 6 March 1820, the king was obliged to issue a decree calling the Cortes, and on the following day he consented to the restoration of the Constitution. ${ }^{4}$ On 26 March 1820 he issued a further decree obliging the people to swear an oath of loyalty to the Constitution. ${ }^{5}$ The Constitution remained in force for three years, and this period was regarded at the time, and has been interpreted to be so since, as Spain's liberal triennium. ${ }^{6}$

It was this decree of 26 March 1820 that elicited Bentham's first response to the new liberal regime in Spain: a letter published in the Morning Chronicle on 18 April 1820. Four days later, prompted by a comment in the Morning Chronicle criticizing the lack of a House of Lords in the Spanish Constitution, Bentham composed a second letter intended for the newspaper, expressing his opposition to aristocratic second chambers, but which, in the event, he did not send. For much of the following two years, Bentham's life and work were dominated by the affairs of Spain, and to a lesser extent by those of Portugal, which adopted, for a brief period, a version of the Spanish Constitution. Bentham's writings are now gathered in two volumes, the above-mentioned Colonies, Commerce, and Constitutional Law and On the Liberty of the Press, and Public Discussion. ${ }^{7}$ In the course of these works, and in particular in his most sustained essay, 'Emancipation Spanish', which he began to draft in the summer of 1820 and which he would virtually complete by April 1822 under the revised title of 'Rid Yourselves of Ultramaria', ${ }^{8}$ he focused on the impact that the attempt of Spain's rulers to retain the overseas Empire would have on the viability of the Constitution. He argued that the Constitution was essentially sound because it recognized the greatest happiness of the greatest number as the proper end of government, but that many of its detailed provisions, and especially those concerning the 
colonies, were ill-conceived in that they opened the door for the return of royal despotism. The fundamental principles of the Constitution were announced in Articles 4 and 13, which recognized that 'the felicity of all the individuals of which the nation or political society in question is considered as being composed' was 'the right and proper end of government: object of pursuit to all measures of government'. ${ }^{9}$ In contrast, Article 1, which proclaimed 'The Spanish Nation consists of all Spaniards of both hemispheres', was a source of great danger, since it enshrined the determination to maintain the Empire. ${ }^{10}$ Referring to those elements among Spain's ruling classes who saw an advantage to themselves from maintaining the claim over Ultramaria, Bentham remarked:

Spain is one! such will be their arithmetic. It has its Peninsular part and its Ultramarian part! such will be their geography. As well might it be said - Spain and the Moon are one! it has its earthly part: it has its lunar part. Such ... is the language of your Constitutional Code. But, a body of human law, how well soever arranged in other respects, does not suffice for converting impossibilities into facts. ${ }^{11}$

Spain's rulers recognized that the overseas possessions represented a major source of corruptive influence, which could be used to re-establish royal despotism. Bentham was worried that other parts of the Constitution tended in the same direction. He asked the Spanish people not to be angry with him for pointing out its flaws: 'He who is angry with me, if it has ever happened to him to have received a wound, let him include in his anger the Surgeon by whom the probe, the knife or the needle have been applied to it.' He asked them to accept that 'in this instrument of preponderant good, arrangements of the opposite character are not altogether wanting: arrangements by which a sacrifice is made of the universal interest to this or that particular and sinister interest'. The mixed government established by the Constitution was unstable: it would dissolve into either a pure despotism or a pure representative democracy. Unless it was reformed, it was 'doomed to perish, and to perish by means of corruptive influence'. His efforts, therefore, were directed towards persuading the Spanish people, and thereby the majority of the Cortes, to strengthen the democratic elements in the Constitution against the inevitable encroachments of the king and his supporters. ${ }^{12}$

In Bentham's view, the existence of the overseas colonies was the main threat to Spain's liberal regime. Hence, Spain should grant independence to her colonies, whereupon she would be financially stronger and militarily more secure, but, more importantly, a great deal of the 
corruption that would otherwise impel the country towards royal despotism would be removed. There would be danger from corruptive influence even if Spain had no overseas colonies, but from the existence of the colonies, or even the claim to the colonies, the danger received 'a boundless encrease'. The 'rich compound of official power, and official emolument, and factitious dignity' that the overseas possessions provided for the king and his supporters enormously increased the opportunities for corruption. ${ }^{13}$

In material composed for 'Emancipation Spanish' in the summer of 1820, Bentham argued that the Constitution, at the same time that it asserted the claim over Ultramaria, made the maintenance of Spain's dominion extremely problematic. The increased freedom, and hence the increased knowledge, under the new constitutional regime would undermine the ignorance that, under the old despotism, had encouraged 'blind submission'. The Constitution, for instance, guaranteed the liberty of the press (Article 371) and the right to send a memorial to the king or the Cortes (Article 373). There were many causes of discontent in Spanish America, and the Constitution gave each Spanish American the opportunity to tell every other Spanish American that he was discontented, and, if he thought it worth his while, to make representation of his discontent to the king and Cortes:

With such real, such ample, such universally-applying cause of discontent, pervading the whole of Spanish America, - with such cause of discontent, and at the same time such unprecedented and uncontroulable means of expressing and propagating it, think whether it could be long, ere, through the several stages of disaffection and disobedience, the discontent would have ripened into revolt. ${ }^{14}$

Moreover, the provision in the Constitution requiring all legislation initiated in Ultramaria to be approved by the Cortes would produce significant problems and consequent suffering in Ultramaria. Without its own legislature, it was as impossible for any province in Ultramaria to be well-governed as it would be for Spain itself. On the part of the Ultramarians, the result would be 'a state either of despondency or rage: of despondency if the abuse were regarded as not susceptible, of rage if it were regarded as susceptible, of remedy by insurrection'. The old despotism would be preferred to the new Constitution, since a despotism always had power to act, at least where it saw its interest in doing so, whereas under the new regime matters would stagnate. ${ }^{15}$ 
There were other provisions in the Constitution that would aggravate the discontent in Ultramaria. The right to elect deputies to the Cortes would be of no benefit to the Ultramarians, since the deputies would be corrupted by the rulers in Spain, and thereby induced to sacrifice the universal interests of both the Spanish and Ultramarian people to the sinister interest of Spain's rulers. Moreover, there had been no census of the inhabitants of Ultramaria, and so it would be impossible to organize elections there according to the procedures laid down in the Constitution. Indeed, the Ultramarian members who had sat in the Cortes of 1812 and that of 1820 had not been regularly elected by their alleged constituents, but appointed by rulers in Spain. ${ }^{16}$ The infallibility-assuming clause (Article 375) meant that there would be no remedy for these problems until eight years had passed 'subsequently to the time when the Constitution has been carried into practice in all its parts'. According to Bentham, the Constitution would not be carried into effect 'in all its parts' in two years, 'nor in two hundred years - nor in two thousand years'. The argument in favour of the provision was that it was 'a short method of disposing of all proposals tending to the restoration of the abolished despotism'. Bentham pointed out that if there were a majority in favour of the new order, then each such proposal could be rejected as and when it was brought forward. If there were a majority in favour of the old order, then the infallibility-assuming article would simply be ineffectual. ${ }^{17}$

Bentham expanded on these concerns in 'Rid Yourselves of Ultramaria', where he identified a series of 'anti-constitutional evils' that would arise from the retention of, or even the attempt to retain, the colonies. The first evil was the addition of Ultramarian deputies to the Cortes. These deputies, who were neither chosen nor removable by the Spanish themselves, would in many matters - for instance, in the levying of taxation - have an interest opposite to theirs. According to the Constitution (Art. 1), the Ultramarians and the Peninsular Spanish were all said to be 'Spaniards', yet, noted Bentham, they were in fact 'strangers' to each other. It was not 'in the power of names to change and reverse the state of interests, the relations between interest and interest, or to destroy the influence of interest on conduct'. ${ }^{18}$ If the terms of the Constitution were put into effect, the Ultramarians would form a majority in the Cortes. The Constitution stipulated that there should be one deputy in the Cortes for every 70,000 'souls' - it was unclear whether this meant women as well as men, though Bentham presumed not; it seemed to be generally accepted that there were more Ultramarians than Peninsulars (the population of Spain was around 12 million, and that of Ultramaria had been estimated 
at over 15.5 million) ${ }^{19}$ In fact, no one would benefit from the Ultramarian representation in the Cortes. It would give no security against misrule to the Ultramarians themselves, and so was worthless to them, and yet would be seriously detrimental to the interests of Spain herself. In practice, the so-called Ultramarian representatives had not been elected by the people of Ultramaria, but consisted of 30 'substitutes' who happened to be living in Madrid at the time of the elections, and attended the Cortes until the regularly elected representatives could arrive. Hence, laws were being imposed on the Spanish people that had been made not by genuine, but by spurious, representatives of the Ultramarians. ${ }^{20}$ Bentham suspected that the spurious representatives had been placed in the Cortes by those who had an interest in maintaining Spain's claim over her colonies, whereas genuine representatives would be opposed to that claim. ${ }^{21}$

The second anti-constitutional evil was the addition that the colonies made to the amount of corruptive influence that could be directed towards the members of the Cortes, whether from the Peninsula or from Ultramaria:

Of this corruptive influence the tendency, and to certainty sooner or later the effect, is to give to these representatives of the people on every occasion a particular interest opposite to the universal interest, and to which, in consequence of the power attached to it, the universal interest will on every occasion of conflict be sure to be sacrificed: to produce, in a word, on their part the correspondent corrupt obsequiousness.

The king and his ministers had money and other 'sweets of government' to distribute to the representatives in the Cortes. In return, the representatives were expected to promote the sinister interest of the king and his ministers. Unless the people intervened in some way, warned Bentham, their representatives would be converted into the tools of 'a virtual despotism - of a government in which, not less compleatly than under a despotism governing by force, the universal interest will be made a compleat sacrifice of to that knot of particular and sinister interests'. The people would be left with nothing beyond what was necessary for bare subsistence. $^{22}$

The drafters of the Constitution, noted Bentham, had recognized the danger of corruptive influence, and had introduced arrangements to counteract it. These arrangements were, either through design or accident, completely inadequate. According to Article 129, deputies, during the period of their deputation, were not permitted to receive 
for themselves, nor solicit for someone else, any employment from the king or promotion in rank. The value of an office, explained Bentham, was not destroyed by a delay, especially when the delay was at most two years, and might be as little as one day. The prohibition of solicitation was pointless, since a person did not have to solicit the king in order for the king to understand that he would be grateful if some office were given to a relative of his. 'A female to whom service in that shape in which sexual desire is ministered to is a source of subsistence, does she never employ means of making it known, other than by making the tender of it in express terms?' Rather than acting as a check to corrupt obsequiousness, this provision was a cover for it: 'yielding to prostitution in this shape' was not prohibited, but merely 'the express offer of [the representative's] services to the corruptor's use'. Furthermore, if solicitation made an appointment to office void, then an enemy of a man about to be appointed to an office could simply solicit on his behalf in order to stop the appointment. According to Article 130, the deputies, during their deputation and for a year afterwards, were prohibited from obtaining for themselves or soliciting for another either a pension or dignity conferred by the king. This was in effect to give the deputy permission to obtain or solicit such a pension or dignity a year after the period of his deputation had ended. This clause, like the previous one, pretended to be prohibitive, but in fact it gave licence. Hence, the deputies of the Cortes, the only body that the Constitution had established in order to restrain the nation from 'running full speed into the gulph of despotism', could look forward to receiving in due course lucrative offices and pensions from the king. Once the retired deputy had been 'loaded with pensions and covered with ribbons', he was then eligible to sit in the succeeding Cortes. Within a few years, predicted Bentham, the Cortes would have no deputies who were not king's pensioners, appointable and removable at his pleasure. ${ }^{23}$ Bentham recognized that it was impossible to remove completely the matter of corruptive influence from the executive for distribution among members of the legislature, but it was possible to reduce the number of 'beneficial official situations' to the minimum, and to reduce the pay attached to each to the minimum, 'with the addition of punishment in case of legally proved corrupt obsequiousness, and public reproach in case of corrupt obsequiousness believed though not legally proved'. A deputy might vote for an increase to the corruption fund, and then his son receive a lucrative office, but he could not be legally punished on this score. His constituents, at the next election, could decide, however, 'whether he is the fittest representative they can have'. ${ }^{24}$ 
The third anti-constitutional evil produced by Ultramaria was doubling the period between elections, and thereby adding to the time during which bad deputies were irremovable. Under the Constitution, the duration of the Cortes had been increased from the customary one year to two years, in order to give the Ultramarian deputies time to travel to and from Spain. One means of reducing corrupt obsequiousness was to limit the length of time for which an office could be held: 'The shorter its duration, the less its magnitude: the less its magnitude, the less the marketable value of it in the event of its being on sale.' The shorter the time that the corrupt service could continue, the less the corruptor would be prepared to give for it; and the shorter the time that the official was secured against removal, the less the quantity of evil he could perform before an end was put to it. The existence of Ultramaria, by occasioning biennial instead of annual elections, had, therefore, weakened 'whatever security you had otherwise for the constitutional probity of [the] deputies'. ${ }^{25}$

The fourth anti-constitutional evil consisted in the demands that Ultramaria would place on the time of the Cortes. Were the Cortes to sit for the whole year, it would not have sufficient time to deal with the affairs of Spain. It was, however, expected to deal with the affairs of Ultramaria as well, and the demands of Ultramaria for the attention of the Cortes would exceed that of Spain itself. If this was not serious enough, the Cortes was not allowed to sit for more than four months each year. There would, predicted Bentham, be many complaints from the Ultramarians to the Cortes (as permitted by Art. 373), as well as disputes over the taxation levied by the Cortes on Ultramaria (Art. 131, clauses 13 and 15; Art. 335, clause 1). Furthermore, since the Constitution had failed to establish any subordinate legislatures in the Ultramarian provinces, all proposed legislation for Ultramaria would have to be dealt with by the Cortes. Under the terms of the Constitution, the smallest and most remote town council could not impose a tax upon its inhabitants without the consent of the Cortes. Bentham lamented that the drafters of the Constitution had simply not been able to conceive of the effect that the change in Spain from a pure monarchy to a government that had within it a significant democratic element would have on Ultramaria - 'and with all the aid they had from self-appointed Colleagues, the sham deputies from Ultramaria, [no] much clearer conception do they appear to have formed of themselves of the state of things in Ultramaria, in its thus projected condition, than if, instead of Ultramaria, they had had the moon to deal with'. ${ }^{26}$

The fifth anti-constitutional evil consisted in the introduction into Ultramaria, and from there into Spain, of a 'latent despotism'. A major 
problem for Spain would be extracting taxation from Ultramaria, since the Constitution had provided a variety of 'facilities for evasion'. The Ultramarians would not pay taxes when the money would either be sent to Spain or used to pay the salaries of officials sent from Spain to Ultramaria in order 'to fatten' them. The Provincial Deputations (the ruling authorities in the colonies), of whose members the majority were Ultramarians, had the power to prevent the levying of any tax in the province (Art. 335). Having said that, at the same time the Constitution had established a potential despotism in the powers given, somewhat surreptitiously, to the governor or political chief of the province. Assuming that the Provincial Deputation proved awkward, the governor, who was appointed by the king, would make use of these powers. The governor was president of the Provincial Deputation, which was given authority 'to promote the prosperity' of the province. The executive authority, moreover, which had been placed exclusively in the king, was pronounced to extend to whatever was 'conducive to the preservation of public order in the interior and to the external security of the state, conformable to the Constitution and the laws' (Art. 170). What all this meant in practice, claimed Bentham, was that the governor had a free hand to do as he pleased. All that he needed was sufficient military force at his disposal. In that case, there was nothing in the Constitution that could prevent the king and his ministers from granting unlimited power to the governor. Any judges who might be in a position to restrain the governor would have been sent from Madrid for the same purposes, and have the same interests, as the governor himself:

In case of any act done by him to the prejudice of the person, reputation, property or condition in life of this or that individual, to them [i.e. the judges sent from Madrid] it would belong to determine whether by such act, notwithstanding the private injury done, the general prosperity of the country were not promoted: the money, for example, necessary to the payment of their own salaries, raised.

In short, the judges would be ciphers. The power of the governor was, in effect, unlimited and, therefore, despotic. ${ }^{27}$

Why was the Constitution so incoherent? Bentham explained that its drafters had faced 'a most perplexing' task - to please the Spanish, the Ultramarians had to be placed under subjection, while to please the Ultramarians, they had to be exempt from subjection. 'To the two opposite parties, the same set of arrangements was to present an object altogether opposite.' The Ultramarians were all along to be ruled by the 
rulers of Spain, but were to be given the appearance of a share in the rule over Spain: 'But the subjection was real: the supposed power not effective power: nothing but a mere phantom of it.' Bentham continued:

Without changing the nature of things, to reconcile such incompatibilities was not in the power of omnipotence. What could not but happen has happened: in the endeavours to keep the Ultramarians in subjection and thence subject to taxation, the authors of your Constitutional Code ... have compleatly failed. Requisitions, so they have ordered matters, will be made, but compliance will not follow: for compliance they have provided no motives: and for non-compliance they have furnished not only adequate motives, but obvious and surely effectual means.

The only hope of effecting subjection was through the 'inlets to despotism' that Bentham had identified in the powers given to the governor. In relation to Ultramaria, the Constitution was like the Frenchman's account of the English drink of punch:

There was the brandy to make it strong: there was the water to make it weak: there was the lemon juice to make it sower: there was the sugar to make it sweet: in a word, it was the liquor of contradiction. $^{28}$

\section{III}

In the late summer of 1820 , Bentham became worried by two events in Spain. The first was the arrest of the Spanish liberal José Joaquín Mora on account of an article he had published in his journal El Constitucional, in which he had criticized the local government of Madrid. Bentham claimed that the successful prosecution of Mora would destroy the liberty of the press. The second was a proposal put forward in the Cortes placing restrictions on public meetings. Bentham saw a translation of the proposed measure in The Traveller, 6 October 1820, and began to write the series of letters that was eventually published as On the Liberty of the Press, and Public Discussion in July 1821. His intention was that his essay should be translated into Spanish by Mora and published before the law was passed. By the time the text had reached Mora, however, it was too late: the measure had become law on 21 October $1820 .{ }^{29}$ Bentham, 
nevertheless, went ahead with the publication of the original English version of the Letters on the grounds that:

the more extensive object which they had in view ... was neither at an end, nor in its nature capable of being put to an end. That object was - the rendering it manifest, how indispensable, at all times and every where, those two intimately-connected liberties - the liberty of the press, and the liberty of public discussion by word of mouth - are to every thing that can, with propriety, be termed good government .... ${ }^{30}$

Bentham contrasted the potential situation in Spain with the actual situation in the United States of America, where no one could be prosecuted for anything written against government, and where there were no restrictions on public meetings, and yet where, since independence, 'public tranquillity has not known what disturbance is' ${ }^{31}$ Bentham recommended that, in relation to both liberty of speech and liberty of writing on political matters, Spain should follow the example of the United States. The Cortes should pass a declaration that the people should remain 'at liberty ... to meet, for the purpose of delivering their opinions, in the freest manner, on the conduct and character of their rulers', or at least of their representatives and those subject to them. ${ }^{32}$

First, in relation to the liberty of the press, Bentham noted that criticism of the form of government was inseparable from criticism of the persons exercising the powers of government, in that the form depended upon the persons. Rulers were prepared to punish both sorts of criticism. If the criticism suggested that a ruler had committed an act that was legally punishable, it was regarded as defamation; if the criticism was 'vague and general', it was regarded as vituperation. Both acts were commonly treated as offences. Moreover, it was common to attach greater punishment to the offence as the rank of the person offended rose: the least punishment was attached where the person offended was a private individual, and the most where it was one of the leaders of the government. In Bentham's view, the more elevated the individual criticized, the less, rather than the more, protection should be afforded to that person by law. More powerful individuals had greater means to defend themselves against accusations of wrongdoing, while the greater rewards they enjoyed acted as compensation for any criticism they might receive. Hence, vituperation directed against a government official should not be made subject to punishment, while there should be no punishment for defamation 'unless the imputation be false and groundless: nor even 
then, unless the false assertion, or insinuation, be the result of wilful mendacity, accompanied with the consciousness of its falsity, or else with culpable rashness'. In short, the truth of the accusation should be a sufficient defence. Bentham continued:

For these notions, speaking in general terms, my reason is - that to place, on any more advantageous footing, the official reputation of a public functionary, is, to destroy or proportionably to weaken, that liberty, which, under the name of the liberty of the press, operates as a check upon the conduct of the ruling few; and, in that character, constitutes a controuling power, indispensably necessary to the maintenance of good government.

Whatever evil could be produced by the exercise of this liberty to offended individuals was massively outweighed by the 'infinite' good it produced as a security for good government. ${ }^{33}$

Second, in relation to the liberty of public meetings, Bentham, having seen the proposed measure regulating public meetings and the justifications put forward by the deputy Nicolás María Gareli in a debate in the Cortes, as reported in The Traveller, 21 September 1820, argued that it would have been better termed the 'law for preventing public meetings', and that its object was, in this respect, 'to place the people of Spain exactly upon the same footing as the people of Morocco'. The law stated that public meetings were not to be held without the permission of the local authority. Only those meetings, remarked Bentham, that it suited the relevant official to allow would go ahead, while those he did not like would be banned. The measure constituted an attempt to establish a despotic government. Bentham would propose a test that would allow the Spanish people to distinguish a supporter of despotic government from that of an undespotic one - in other words, to distinguish a hater from a lover of liberty - but before he could do this, some preliminary explanations would be necessary. The characteristic feature of 'an undespotic government', he noted, consisted in 'some eventual faculty of effectual resistance, and consequent change of government, ... purposely left, or rather given, to the people'. To the objection that this was dangerous, Bentham retorted that the subject many - his term for the people in general - always had a 'disposition to obsequiousness', and that nothing 'short of the extremity of misrule' had ever produced revolution. Three 'instruments' were necessary to maintain a disposition to eventual resistance: 
instruction, excitation, correspondence. To the understanding applies instruction; to the will, excitation: both are necessary to appropriate action and correspondent effect: instruction and excitation, in the case of each individual taken separately: correspondence, for the sake of concert amongst the number of individuals requisite and sufficient for the production of the ultimate effect.

All three elements contributed to maintaining 'the national mind' in 'a state of preparation for eventual resistance'. Such a state of preparation both made possible a change in government, if necessary, and in the meantime prevented, or retarded, that necessity by constantly applying a check to misrule:

Necessary to instruction - to excitation - in a word to a state of preparation directed to this purpose, is - (who does not see it?) the perfectly unrestrained communication of ideas on every subject within the field of government: the communication, by vehicles of all sorts - by signs of all sorts: signs to the ear - signs to the eye by spoken language - by written, including printed, language - by the liberty of the tongue, by the liberty of the writing desk, by the liberty of the post office - by the liberty of the press.

This was new neither in theory nor in practice. The principle was openly avowed in the United States Declaration of Independence, which thereby 'laid the foundation of eventual resistance to itself'. While disapproving of the 'logic' of the declaration, Bentham was prepared to admit that there was 'thus much in it of good politics'.

Having explained the distinction between a despotic and undespotic government, Bentham announced his test: the question was whether a person would agree to arrange matters in relation to the liberty of the press and public discussion such that no one should have more to fear from speaking and writing against those exercising the powers of government than from speaking and writing in their favour. If the person answered yes, this was to declare in favour of an undespotic government; if no, in favour of a despotic one. If yes, the person's principles were those of the United States and the Spanish Constitution; if no, they were those of the Emperor of Morocco. On this basis, those who supported the proposed measure to restrict public meetings were supporting the reintroduction of despotism. The Constitution itself prevented political discussion at the parish elective meetings, the first stage of the four-stage electoral process. There was, therefore, no instruction, 
excitation or correspondence among the electors. The proposed measure consummated the process by depriving people 'of all other opportunities of learning the mental exercise; that instrument of independence by which alone man is distinguished from the puppet. ${ }^{34}$

\section{IV}

A third short but insightful commentary on the Spanish Constitution appeared in an essay entitled 'Letter to the Portugueze Nation, on Antiquated Constitutions; on the Spanish Constitution Considered as a Whole, and on Certain Defects Observable in It', which was published in the summer of 1821 as the third of his Three Tracts on Spanish and Portugueze Affairs. ${ }^{35}$ The Portuguese were in the process of adopting a new constitution based on the Spanish model. Bentham's aim was to warn them to avoid certain defects he had identified in the Spanish Constitution, while recommending its overall adoption, since it enshrined the democratic principles that he had himself advocated in Plan of Parliamentary Reform (1817), namely universality, secrecy, equality and annuality of suffrage - albeit elections in Spain would be biennial, and consist in four stages of election, as opposed to Bentham's one. The Spanish Constitution represented a major improvement over Portugal's ancient regime: 'The one thing needful is that by which the interest of the ruler is made the same with that of subject; of representative with that of constituent. This is what the Spanish constitution may be brought to do for you. This is what your old stale constitution never did, nor ever would be brought to do, for any body. ${ }^{36}$

There were, however, four provisions within the Spanish Constitution that Bentham condemned. The first was ' $[\mathrm{t}]$ he immutability-enacting, alias the infallibility-assuming clause' (Art. 375). This clause prohibited any amendment to the Constitution for at least eight years. 'Immutability in the work, assumes infallibility in the workman': such an assumption was impossible to reconcile with sanity, since even if the legislator were infallible today, he would not remain so as time progressed. Bentham recognized that there was some reason for 'this absurdity', namely the fear of a return to despotism. The Portuguese, however, did not need to concern themselves in this regard, since the king was in Brazil. ${ }^{37}$

The second provision in the Spanish Constitution that Bentham encouraged the Portuguese to discard was non-re-eligibility (Arts 108, 110) - that is, preventing the deputies of the first Cortes from sitting in the second. This was to jettison experience, even though, as the English 
proverb maintained, experience was the mother of wisdom. To object that the deputies to the first Cortes might otherwise make their power perpetual was to ignore the fact that they could be removed every two years. If they proved themselves unfit, they would not be re-elected. The non-re-eligibility provision was undiscriminating in its application the most meritorious and the guiltiest representatives were removed together, without any opportunity for constituents to exercise their judgements in each individual case. The representative who had conducted himself well was thereby denied 'the correspondent and natural reward', namely re-election. The fact that the representatives elected to the first Cortes could be elected to the third merely added to the complication. The author of the Constitution, in condemning the whole group of representatives together, assumed that he had greater knowledge of the men elected to the first Cortes, whom he did not know, than their electors did - he might as justifiably have excluded those who sat in the 51st Cortes from the 50th. ${ }^{38}$

By prohibiting legal changes, one of the bad effects of an immutability-enacting clause was to produce 'anti-legal changes'. By prohibiting regular amendment of the law, it encouraged the legislator himself to violate the law, and this in turn would encourage violation of the law throughout the community. An example of this was in relation to the non-re-eligibility clause. Despite the prohibition laid on representatives sitting in two successive Cortes, there were many members in the Cortes of 1820 who had also sat in the previous Cortes of 1812 . Bentham asked: 'In the decree, by which the constitution was established, was any amendment made as to this clause? If yes, then was the immutability clause violated: if no, then was the non-reeligibility clause violated'. Hence, the tendency of an immutability-enacting clause was 'to plant anarchy, and to destroy confidence.'. ${ }^{39}$

The third defect was the sleep-compelling clause (Arts 106-7), which limited the duration of the sitting of the Cortes to three months each year, with the possibility of an extension for a further month. 'If there be one thing more impossible than another, surely it will be - the saying at any time of the year, upon any sure grounds, what time may be requisite and sufficient to the business: to the business that may, in the course of the remainder, happen to require to be done.' If this was the case when everything had long been settled, it was still more so at a time when nearly everything still needed to be settled, and especially when the representatives themselves were new. 'If such be the case, in a nation which (like the French), is more apt to go beyond the proper pace than fall short of it, in how much greater a degree must it not be 
the case in a nation, which, if proverbs are not slanderers, ${ }^{40}$ is so much more apt to fall short of the mark, than to go beyond it?' The supreme power in the state - the king and Cortes - was thereby doomed to impotence for two-thirds of the year, without any reason assigned in justification. ${ }^{41}$ In On the Liberty of the Press, and Public Discussion, Bentham had addressed the same theme: 'By this strange article of the constitutional code, the Cortes, the only assembly in which, should misrule reassume its recent enormity, the voice of complaint can be heard, is laid asleep ... for eight months.' Meanwhile, the powers of government were lodged in the hands of ministers appointed by the king (Art. 171 (5)). At this time, he claimed that he was not so much concerned that the restoration of despotism would be the consequence of the eight months' 'sleep' of the Cortes, since the new ministers had the same interest as the subject many in securing themselves from such an eventuality. However, as he went on, it seems that this was precisely his concern. He was afraid, he noted, that ministers 'will do what all men would be disposed to do in their places: that they will embrace every opportunity for sacrificing the interest of the whole community to their own particular interests', and hence increase to the utmost the number of sinecure offices, increase to the utmost the amount of official pay, dispose of such offices for their own profit without regard to the aptitude of the persons appointed to them, increase the expenditure of government as far as was practicable, and punish all persons who had incurred their displeasure. In order to make this system permanent, they would enter into an alliance with the monarch and aristocracy, and in particular the proprietors of large estates. The measures already taken in the Cortes by ministers 'for the extinction of all power of control in the hands of the people, may, by means of such an alliance, be carried into full execution, and perfected and perpetuated'. Closing the Cortes for eight months was akin to locking up all the sheepdogs for eight months, 'and the sheep committed during that time to the guardianship of the wolves'. ${ }^{42}$

The fourth amendment that Bentham recommended the Portuguese to make to the Spanish Constitution was to replace biennial elections (Art. 108) with annual elections. The reason for the Spanish biennial clause was Ultramaria. If the duration of the Cortes had been but one year, the overseas representatives might have spent most of the year travelling to and from their constituencies. With the biennial clause, only half the time would be wasted in this way. Bentham congratulated the Portuguese on the fact that they had been 'eased of' much of their Ultramaria by John VI's removal to Brazil, and hoped that they would allow him to take the rest of the Portuguese colonies. 
'You will look down with an eye of sympathy on your neighbours the Spaniards, who are still incumbered and drained by the sort of nuisance of which you are rid.' Being rid of their colonies, the Portuguese had removed one of the potential sources of dispute with the Spanish. Bentham advised the Portuguese to 'Unite yourselves to those same neighbours by the closest bonds. ${ }^{24}$

\section{V}

Having pointed out some of the 'imperfections' in the detail of the Constitution, and stating that these were only a small part of those that he had identified, Bentham still referred to it as 'this so extensively beneficent and wonder-working Code' and as 'this momentous work'. Its 'excellence', and hence his approval, was grounded on a small number of clauses: 'the only legitimate end of government' as recognized in Articles 4 and 13; and 'the essential means: the choice of the ruling few placed in the hands of the subject many: to the exercise of a man's share in this choice, no bar opposed but that which it is in a man's own power to remove' as recognized in Articles 34-5. Other nations were well advised to adopt the Spanish Constitution: 'To each of these nations, what a treasure was this which their good fortune had thus placed in their hands!' It was no good destroying an existing government unless there was some other to put in its place, and the Spanish Constitution was the best available. ${ }^{44}$

Bentham did his best to keep up with developments in Spain, and with organizing translations of his works. Despite his efforts, he always seemed to be overtaken by events. Just as he had identified the distance between Spain and her overseas colonies as a major impediment to effective governance, the relatively much shorter distance between Spain and England, and the difficulty of receiving accurate and reliable information, meant that, even if there had been an audience for Bentham's works, they were unlikely to have a significant impact. Yet having said that, what is striking is just how well grounded were Bentham's fears concerning the re-establishment of royal despotism. He argued that a mixed constitution was essentially unstable and would inevitably move towards despotism or democracy. The tendency of measures passed by the Cortes, in Bentham's view, was moving Spain back towards despotism. His fears were realized: the Spanish liberals were either not able or not willing to introduce more robust measures of democratic reform into the Constitution and the political system, and thereby prevent the restoration in 1823 of Ferdinand VII's personal rule. 


\section{Notes}

1. Jeremy Bentham, Colonies, Commerce, and Constitutional Law: Rid Yourselves of Ultramaria and Other Writings on Spain and Spanish America, ed. P. Schofield (Oxford: Clarendon, 1995).

2. Ferdinand VII had succeeded to the throne in 1808 , but had been forced to abdicate by Napoleon, who had installed his brother Joseph Bonaparte, previously King of Naples, in his place.

3. Decretos del Rey Don Fernando VII, 18 vols (Madrid, 1818-1834), i. 1.

4. J. Muñiz Miranda, Coleccion Oficial de las Leyes, Reales disposiciones, y Circulares de interés general, espedidas por el rey don Fernando VII y por las Córtes en el año de 1820 (Madrid, 1853), 24-5.

5. Miranda, Coleccion Oficial, 77.

6. See C. W. Fehrenbach, 'Moderados and Exaltados: The Liberal Opposition to Ferdinand VII, 1814-23', Hispanic American Historical Review 50 (1970): 52-69.

7. Jeremy Bentham, On the Liberty of the Press, and Public Discussion and other Legal and Political Writings for Spain and Portugal, eds. C. Pease-Watkin and P. Schofield (Oxford: Clarendon, 2012).

8. Bentham coined the term 'Ultramaria' from the Spanish word ultramar, i.e. overseas, to refer to the colonies of Spain.

9. Bentham, Colonies, 31.

10. For the lack of any significant opposition to the retention of the colonies on the part of both liberales and serviles in Spain, see M. P. Costeloe, Response to Revolution: Imperial Spain and the Spanish American Revolutions, 1810-1840 (Cambridge: Cambridge University Press, 1986).

11. Bentham, Colonies, 52-3.

12. Bentham, Colonies, 28-9, 86.

13. Bentham, Colonies, 23-4.

14. Bentham, Colonies, 155-6.

15. Bentham, Colonies, 162-6.

16. Bentham, Colonies, 166-9.

17. Bentham, Colonies, 183-4.

18. Bentham, Colonies, 76-7.

19. Bentham, Colonies, 77-8.

20. Bentham, Colonies, 81-2.

21. Bentham, Colonies, 84-5.

22. Bentham, Colonies, 85-6.

23. Bentham, Colonies, 86-9.

24. Bentham, Colonies, 92.

25. Bentham, Colonies, 93-4.

26. Bentham, Colonies, 94-100.

27. Bentham, Colonies, 101-11.

28. Bentham, Colonies, 188-90.

29. Bentham, Liberty of the Press, Editorial introduction, xvii-xviii.

30. Bentham, Liberty of the Press, 4.

31. Bentham, Liberty of the Press, 8.

32. Bentham, Liberty of the Press, 16-17.

33. Bentham, Liberty of the Press, 11-13.

34. Bentham, Liberty of the Press, 23-34.

35. The work is reproduced in Liberty of the Press, 53-111.

36. Bentham, Liberty of the Press, 101-2.

37. Bentham, Liberty of the Press, 102-3.

38. Bentham, Liberty of the Press, 103-6.

39. Bentham, Liberty of the Press, 107-8.

40. For the reputation of the Spanish for being slow, see Francis Bacon, The Essayes or Counsels, Civill and Morall, ed. M. Kiernan (Oxford: Clarendon, 1985; first published 1597-1625), Essay XXV, 'Of Dispatch', 77: 'The Spartans, and Spaniards, have been noted to be of Small dispatch; Mi venga la Muerte de Spagna; Let my Death come from Spaine; For then it will be sure to be long in comming'.

41. Bentham, Liberty of the Press, 106.

42. Bentham, Liberty of the Press, 18-21.

43. Bentham, Liberty of the Press, 106-7.

44. Bentham, Colonies, 190-2. 


\section{Bibliography}

Bacon, Francis. The Essayes or Counsels, Civill and Morall. Edited by M. Kiernan. Oxford: Clarendon, 1985.

Bentham, Jeremy. Colonies, Commerce, and Constitutional Law: Rid Yourselves of Ultramaria and Other Writings on Spain and Spanish America. Edited by P. Schofield. Oxford: Clarendon, 1995.

Bentham, Jeremy. On the Liberty of the Press, and Public Discussion and Other Legal and Political Writings for Spain and Portugal. Edited by C. Pease-Watkin and P. Schofield. Oxford: Clarendon, 2012.

Costeloe, M. P. Response to Revolution: Imperial Spain and the Spanish American Revolutions, 1810-1840. Cambridge: Cambridge University Press, 1986.

Decretos del Rey Don Fernando VII, 18 vols. Madrid, 1818-1834.

Fehrenbach, C. W. 'Moderados and Exaltados: The Liberal Opposition to Ferdinand VII, 1814-23', Hispanic American Historical Review 50 (1970): 52-69.

Muñiz Miranda, J. Coleccion Oficial de las Leyes, Reales disposiciones, y Circulares de interés general, espedidas por el rey don Fernando VII y por las Córtes en el año de 1820. Madrid, 1853. 


\section{4 \\ Scepticism and Epicureanism: From David Hume to J. S. Mill}

James Moore

It was a source of acute and persistent irritation to David Hume that his Scottish critics directed their criticisms of his philosophy against $A$ Treatise of Human Nature, published in 1739-1740, when they should have focused their attention upon An Enquiry Concerning Human Understanding and An Enquiry Concerning the Principles of Morals, published in 1748 and 1751 and reprinted together eight times, including the posthumously published edition of 1777. In an advertisement prefaced to the 1777 edition, Hume described the Treatise as a juvenile work which the Author never acknowledged ...', which was 'projected before he left College and which he wrote and published not long after'. He advised his readers that: 'Henceforth, the Author desires, that the following pieces may alone be regarded as containing his philosophical sentiments and principles. ${ }^{1}$ Hume described his advertisement, in a letter to his publisher, William Strahan, as 'a compleat Answer to Dr. Reid and to that bigoted silly Fellow, Beattie'. ${ }^{2}$

Hume's advice to his readers was not followed by his Scottish critics, by Thomas Reid or by Hume's friend, Adam Ferguson, or by Jeremy Bentham, James Mill and John Stuart Mill: all of them continued to focus their attention on the Treatise. They read the Treatise as a work that brought together extreme or Pyrrhonian scepticism and Epicureanism. This was an association that had been elaborated at length by Jean-Pierre de Crousaz, in his Examen du Pyrrhonisme, ancien et moderne, published in 1733, in a single double-columned volume of 776 pages. Crousaz found this combination of Pyrrhonian scepticism and Epicureanism in the work of Pierre Bayle. As a Pyrrhonian sceptic, Bayle 
ought to have been indifferent in his moral and political judgements; instead, he endorsed the moral principles of Epicureans, the principles of utility and agreeableness. He reproduced a character sketch in which Bayle was described as:

a genius capable of understanding anything, no matter how profound, but he wrote sometimes in haste, and enjoyed making light of serious matters. Besides, one cannot justify the excess of love this author had for the desolate obscurity of Pyrrhonism. ${ }^{3}$

Crousaz was reproducing a description of Bayle's intellectual character written by the Chevalier Andrew Michael Ramsay, Hume's host in France, where Hume wrote and refined the Treatise in Rheims and in La Flèche from 1734 to 1737. Hume advised a fellow Scot, also named Michael Ramsay, of what he should read to understand the argument of the Treatise: he should read the works of Malebranche, Berkeley, Bayle and Descartes. Hume was calling attention principally to Book I, Parts II and IV of the Treatise, on the ideas of space and time and on the sceptical and other systems of philosophy. Pyrrhonian scepticism is also evident in other parts of the Treatise, in Book II, on the passions, and Book III on justice and the natural virtues.

Crousaz had much to say on the subject of the passions in his Examen du Pyrrhonism. He had also outlined a review of the passions in his Logique translated in 1724 as A New Treatise on the Art of Thinking. He explained that it was entirely appropriate to discuss the passions in a work on logic, inasmuch as the passions, particularly the more violent passions, make it difficult to think logically and rationally. He considered the most violent passions to be self-love, love of sensual pleasure, love of fame and love of riches. It is remarkable that these were the passions that Hume considered indispensable for life in society. And love of fame and esteem for the rich and powerful prompted Hume to introduce the concept of 'sympathy' in the Treatise to reinforce his explanation of the passions by the association of ideas and impressions.

Hume declared, in An Abstract of a Treatise of Human Nature, published in 1740 , 'if anything can intitle the author to so glorious a name as that of an inventor, 'tis the use he makes of the principle of the association of ideas'. The association of ideas, related in the imagination, judgement and reasoning by their resemblance contiguity and causation, enlivens ideas, imparting to those ideas the vivacity of impressions. In his application of the association of ideas to the passions, and the reinforcement of those associations by sympathy, Hume was providing a defence of the 
moral psychology identified by Crousaz, Chevalier Ramsay and others as Pyrrhonian scepticism.

In Book III, Parts II and III, Hume continued his defence of Pyrrhonian scepticism in opposition to the most distinguished natural rights theorist of the early eighteenth century, Jean Barbeyrac, who had aligned himself with Grotius, Pufendorf and Locke and the Stoic tradition of natural law against the Pyrrhonism of Bayle. Hume argued that property could not be considered a natural right, as Locke had argued, because one can always imagine that a man may be separated from his possessions. Property is a species of causation, and in any causal relation, the cause may be separated from the effect. The imagination and the self-love of men must be regulated by an agreement of judgements or conventional restraints upon avarice and ambition. It is another association of ideas that provides the source of allegiance to government, which provides a remedy for the absence of proximity or contiguity as societies increase in size and in numbers. And, finally, Hume argued that rules of politeness provide a remedy for the resemblance of proud men who cannot fail to provoke one another by their vainglory and self-conceit. In all of these exercises of imagination and judgement, Hume was employing the association of ideas against the Stoic theories advocated by, among others, Barbeyrac and Crousaz. ${ }^{4}$ This was the understanding of Hume's philosophy, at once sceptical and Epicurean, that engaged the attention of Scottish and English readers from Reid and Ferguson to Bentham, James and John Stuart Mill.

II

In An Abstract of the Inquiry into the Human Mind on the Principles of Common Sense, Thomas Reid wrote:

Ever since the Treatise of Human Nature was published, I respected Mr. Hume as the greatest metaphysician of the age, and have learned more from his writings in matters of that kind than from all others put together. I read that treatise over and over with great care, made an abstract of it and wrote my observations upon it. I perceived that his system is all founded upon one principle, from which his conclusions, however extraordinary, are deduced with irresistible evidence. The principle I mean is, that all objects of human thought are either impressions or ideas; which I was very much disposed to believe until I read that treatise; but finding that if this is true I must be an absolute sceptic, I thought that it deserved a careful examination. ${ }^{5}$ 
In Essays on the Active Powers of Man, Book V, Chapter V, Reid offered an appraisal of Hume's theory of morals. He chose to bring together for the purposes of this exercise Book III of the Treatise and An Enquiry Concerning the Principles of Morals: 'In these two works on morals the system is the same ... in both systems, pleasure is the only end, the only thing that is good in itself, and desirable for its own sake.' ${ }^{6}$ In Hume's systems, the proper object of moral approbation is not actions or any voluntary exertion but qualities of mind: natural affections or passions, which are involuntary and common to us and even to brute animals. In Reid's judgement, Hume's moral philosophy was clearly Epicurean. Hume's system differed from Epicureans in one thing: it allowed for disinterested affections, such as benevolence and other natural virtues that are always agreeable. There are other qualities of character that are not always agreeable, but they are useful to ourselves and to others. But, Reid declared: 'Agreeableness and utility are not moral conceptions, nor have they any connection with morality." Hume's system, in short, was directly contrary to the account Reid had given of the active power of the human mind: 'If God has given to man a power which we call conscience, the moral faculty, the sense of duty, then Hume's theory must be false."

Reid also rejected Hume's argument that there must be a motive to be virtuous, distinct from a love of virtue. Reid remarked:

This maxim of Mr. Hume, that no action can be morally good, unless there be some motive to produce it distinct from its morality, is so far from being undoubtedly true, that it must be undoubtedly false. It was never, so far as I know, maintained by any moralist, but by the Epicureans; and it savours of the very dregs of that sect. ${ }^{9}$

It was not only the Epicureans who thought that the Stoic virtue lacked a motive; this problem with Stoic virtue had also been remarked on by Cicero, as Hume had reminded Hutcheson. It was a problem for Hume that in Hutcheson's moral sense theory, virtue (benevolence) should be sought for its own sake. Hume referred Hutcheson to Cicero, De Finibus Bonorum et Malorum, Book IV, where Cicero, writing as a sceptic, opposed the Stoics for failing to recognize that there must be a motive to be virtuous distinct from the love of virtue: 'You [Cato], who have no other standard in view but abstract right and morality will not be able to find a source and starting point for duty and for conduct.' Cicero charged the Stoics with inconsistency in proceeding first to ascertain the supreme good and only then searching the natural desires and instincts to discover a motive; they should have included these desires and motives from the 
beginning of their reasoning, for 'it is these things which excite desire and give motives to conduct'. ${ }^{10}$

As Hume read Cicero, he must have found a similar line of reasoning in De Officiis: that the way to the honestum, to that which would be worthy of praise and honour even if no one made it an object of praise or honour, must be through utilitas, which Cicero represented typically as love of fame. The fame must be deserved, it must be consistent with the honestum, which is the standard or foundation of morality, but in the absence of the passions, of the love of fame, of desire for esteem, of interest, there would be no motive to be virtuous.

\section{III}

On 12 April 1759, Hume told Adam Smith of a manuscript he had received from Ferguson entitled $A$ Treatise of Refinement. Hume liked what he read. He remarked on this manuscript that 'with some amendment, it will make an admirable book and discovers an elegant and singular genius'. ${ }^{11}$ Some years later, he read what appears to have been a revised and expanded version of this manuscript, now entitled An Essay on the History of Civil Society. Hume now disagreed with basically everything. He told Hugh Blair:

I have perus'd Ferguson's papers more than once ... I am sorry to say it ... I do not think them fit to be given to the Public, neither on account of the Style nor the Reasoning: the Form nor the Matter ... It is needless to enter into a Detail, where almost everything seems to me exceptionable. ${ }^{12}$

Hume's disagreement with Ferguson's An Essay on the History of Civil Society (1767) can be explained in part, perhaps, by the repeated challenges to Hume's political ideas that appear in the Essay. I would suggest that the Essay can be read as a dialogue with Hume, that in this light, their disagreement may be considered an episode in the ongoing early modern debate between Stoics and Epicureans. ${ }^{13}$

Ferguson described the respective characters of Epicureans and Stoics in the Principles of Moral and Political Science:

The Epicurean was a deserter from the cause of his fellow-creatures, and might justly be reckoned a traitor to the community of nature, of mankind, and even of his country, to which he owed his protection. 
The Stoic was a man of a different character:

The Stoic enlisted himself as a willing instrument in the hand of God, for the good of his fellow-creatures. For himself, the cares and attentions which their object required were his pleasures; and the continued exertion of a beneficent affection, his welfare and his posterity. ${ }^{14}$

The reader is left in no doubt where Ferguson stood in the debate between Epicureans and Stoics. Hume had caricatured the Epicurean philosophy in his essay 'The Epicurean', when he characterized the Epicurean as a man interested only in the pursuit of pleasure: this was the frivolous philosophy of Aristippus and the Cyrenaics. ${ }^{15}$ In An Enquiry Concerning the Principles of Morals, Hume dissociated himself from philosophers who would reduce all passions to modifications of self-love: he included Hobbes and Locke in this company. ${ }^{16}$ But there were other themes in Hume's moral and political writings, principally in the Treatise, that reflect the principles of modern Epicureans: Gassendi, Bayle, the Baron des Coustures and St Evremond: (1) his depiction of the state of nature as a condition of poverty, weakness and insecurity; (2) his insistence that justice and the institutions of society are artificial; (3) his argument that justice has its origin in a convention of abstaining from the possessions of others; and (4) his conviction that the happiest societies are modern commercial and polite societies.

Ferguson, in the Essay, challenged each of these propositions. (1) In Part I, Section I of the Essay, he replied to the question: 'Where is the state of nature to be found?' He answered this question (as Hutcheson did in his inaugural lecture) that the state of nature is found whenever men act in a manner consistent with their own nature: in Ferguson's judgement, this happens whenever men exercise their minds as active, intelligent beings. 'While this active being is in the train of employing his talents and of operating on the subjects around him, all situations are equally natural. ${ }^{17}$ (2) Ferguson rejected the distinction between natural and artificial, as Hutcheson did, but in an idiom distinctively his own: 'We speak of art as distinguished from nature; but art itself is natural to man ... If the palace be unnatural, the cottage is so no less; and the highest refinements of political and moral apprehension are not artificial in their kind, than the first operations of sentiment and reason.' ${ }^{18}$ (3) Whereas Hume had discovered the origin of justice in a convention of abstinence and thought that the rules of justice were mutually supporting, like stones in an arch, Ferguson discovered the origin of justice in the principle of 
virtue that Montesquieu considered the animating spirit of the laws in republican governments: the love of equality. ${ }^{19}$ It is a principle, Ferguson remarked, that may be forgotten by those accustomed to unequal distribution of goods and subordination of ranks. He considered the relations of men in society 'not merely, like stones in a wall or an arch, that of relative position and place, but of activity and of co-operation in different functions, or of balance, counterpoise and mutual creation ... ${ }^{20}$ (4) Ferguson was appreciative of the benefits that follow from commerce, as Hume described them: refinement of the arts, politeness, regular administration of the laws and of justice. But, Ferguson countered, unless one also cultivates the virtues of rude and barbarian societies, courage and fortitude, one may find that civil liberty has been lost. If one lacks the courage to protest when prisoners are held interminably without trial or are tortured to produce evidence that can be used against them, then governments, whether monarchical or republican, will lapse into despotism. Here one may recognize Montesquieu's analysis of the three forms of government transposed by Ferguson on a historical trajectory:

We must admire as the key-stone of civil liberty, the statute which forces the secrets of every prison to be revealed, the cause of every commitment to be declared, and the person of the accused to be produced, that he may claim his enlargement or his trial within a limited time. No wiser form was ever opposed to the abuses of power. But it requires a fabric no less than the whole constitution of Great Britain, a spirit no less than the refractory zeal of this fortunate people to secure its effects. ${ }^{21}$

Hume was generally sceptical of the virtues of the active citizens of ancient Greece and Rome. His preference was for the polite societies of modern Great Britain and France. He had reason to be sceptical of the politics and manners of the ancient world, and was convinced that the most important virtue, the sentiment of humanity, the foundation of morality, was to be found more often in modern polite and commercial societies. In a section of the Essay, 'Of the Corruption Incident to Polished Nations', Ferguson expressed concern about the indifference to objects of a public nature in polished societies, that men were more inclined to value their private ease and tranquillity, that:

in this condition the mind becomes enfeebled and men generally flatter their own imbecility under the name of politeness. They are persuaded that the celebrated ardour, generosity and fortitude of 
former ages, bordered on frenzy, or were the mere effects of necessity ... . They congratulate themselves on having escaped the storm which required the exercise of such arduous virtues; $\ldots . .{ }^{22}$

One may ask whether Hume ever responded to Ferguson's sallies against his moral and political ideas. There is an account, written by John Home, a mutual friend of Ferguson and Hume, of a journey to Bath, taken in April or May 1776, the last year of Hume's life:

Nothing occurred worthy the writing down, except Mr. David's plan of managing his kingdom, in case Ferguson and I had been princes of the adjacent states. He knew very well, he said (having often disputed the point with us) the great opinion we had of military virtues as essential to every state; that from those sentiments rooted in us, he was certain he would be attacked and interrupted in his projects of cultivating, improving and civilizing mankind by the arts of peace; that he comforted himself with reflecting, that from our want of economy and order in our affairs, we should be continually in want of money; whilst he would have his finances in excellent condition, his magazines well filled, and his naval stores in abundance; but that his final stroke of policy, upon which he depended, was to give one of us a large subsidy to fall upon the other, which would infallibly secure to him peace and quiet, and after a long war, would probably terminate in his being master of all three kingdoms. ${ }^{23}$

\section{IV}

In a lengthy note to $A$ Fragment on Government, Jeremy Bentham recalled the delight he experienced upon reading Book III of $A$ Treatise of Human Nature: 'I felt as if scales had fallen from my eyes. I then, for the first time, learnt to call the cause of the people the cause of virtue.' He discovered not only that the theory of the original contract, a staple of the early modern natural law tradition (endorsed by Hutcheson and by Reid), 'had been effectually demolished by Mr. Hume', he also found 'that the foundations of all virtue are laid in utility is there demonstrated..${ }^{24}$ Bentham meant by the principle of utility 'that principle which approves or disapproves of every action whatsoever, according to the tendency which it appears to have to augment or diminish the happiness of the party whose interest is 
in question'. He made it clear that the party whose interest is in question should always be understood to refer to an individual: 'It is in vain to talk of the interest of the community without understanding what is in the interest of the individual ... The community is a fictitious body, composed of the individual persons who are considered as constituting as it were its members. ${ }^{25}$

Thus far, Bentham's formulation of the principle of utility and its application to society is consistent with Hume's understanding of society and the individuals who comprise it. Hume thought of society as an artificial institution that had its origin in an agreement of judgements made by individuals who understood that it was in their interest to live in society. This was 'the natural obligation', the original motive that restrained the avarice and ambition of individuals and prompted them to believe that life in society was in their interest.

In his celebration of the Treatise, Bentham confined his praise to Book III. He thought that Books I and II might be passed over, that Hume himself would not be 'ill disposed, at present, to join with those who are of opinion that they might, without any great loss to the science of Human Nature, be dispensed with. The like might be said, perhaps, of a considerable part, even of this. ${ }^{26}$ It should be said at once that the Treatise made a greater and more lasting impression on Bentham than any other work of Hume's. But he may have been prepared to write dismissively of Books I and II because he had discovered in the writings of other philosophers an understanding of experimental reasoning more congenial for his own project of censorial jurisprudence and reform. He had learned from Claude Adrien Helvétius that pains and pleasures could be measured as units of sensation. And he had learned that Cesare Beccaria that the criteria for such calculations could be reduced to a formula or felicific calculus that considered the intensity, duration, propinquity and fecundity of pleasures and pains. ${ }^{27}$

These men were also the authors in whose writings Bentham found the phrase 'the greatest happiness of the greatest number'; he sometimes also included Joseph Priestley in this list. He made no mention of Francis Hutcheson in this connection. Hutcheson had used the same phrase in An Inquiry into the Original of Our Ideas of Beauty and Virtue (1725). ${ }^{28}$ And it is possible that any one of Helvétius, Beccaria or Priestley may have taken over the 'greatest happiness' phrase from Hutcheson's work; but, like Bentham, not one of them mentioned Hutcheson in this connection. Two fine scholars, W. R. Scott, the biographer of Hutcheson, and Robert Shackleton, the biographer of Montesquieu, have attempted 
to trace indirect connections between Hutcheson and the authors cited by Bentham, ${ }^{29}$ but a consideration that may prompt some scepticism of this scholarly enterprise is that Hutcheson did not have the interests of individuals in mind when he wrote about happiness. He maintained that happiness, true happiness, could be found only in virtue. And he had his own felicific calculus that allowed him to measure the momentum of virtue in any act or character. His formula was $\mathrm{M}$ (for momentum of virtue $)=\mathrm{B}$ (for benevolence) - (minus) $\mathrm{I}$ (for interest).$^{30} \mathrm{He}$ would subtract motivation derived from interest from the benevolent motivation of the act or character to discover the virtue of the person or the deed. Hutcheson's formula is not what Bentham or Helvétius or Beccaria had in mind when they wrote of the greatest happiness of the greatest number. They believed, as did Hume, that societies and governments must assume that individuals will pursue their own interests and take such interested behaviour into account in determining the laws and rights of individuals.

It may be instructive, in this context, to compare Hume and Bentham in their respective treatments of the right of property. Élie Halévy thought Bentham owed his theory of the right of property to Hume. ${ }^{31}$ And Hume's discussion of the origin of justice and property and the rules that determine property may have been Bentham's point of departure. There are at least three aspects of Bentham's theory of property that may be indebted to Hume. First, Bentham followed Hume in rejecting the justification of private ownership on the grounds of natural law or natural right. In A Fragment on Government, Bentham characterized all such approaches as absurd, on the basis that they ascribed legal relationships to a condition, the state of nature, whose very meaning depended upon the assumption that law in such a state did not exist. ${ }^{32}$ In the most systematic of his discussions of property, in the 'Principles of the Civil Code', Bentham unequivocally insisted on the dependence of the institution of property upon positive or human law: 'Property and law are born together and die together. Before laws were made there was no property; take away laws, and property ceases. ${ }^{33}$ But if Bentham was indebted to Hume in this matter, the differences in the manner in which they worked out their theories are no less remarkable. For law, in Bentham's thought, was never merely convention: in the absence of a command given by a superior person or persons (governors) to others (subjects) who are in the habit of obeying those commands, there was no law, and indeed no society, properly speaking. ${ }^{34}$ Thus, rights, including the right of property, were never understood by Bentham as merely the use and enjoyment of objects acknowledged as the property of individuals by the conventional 
abstinence of others from those possessions. Rights, for Bentham, did not exist, until they were legislated into existence by the commands of governments in the form of statute law, or by the quasi-commands of judges in courts of common law.

Second, the institution of property, for Bentham as for Hume, was the best means of providing security for individuals, and security in Bentham's scheme of things, was 'the principle object of law', and 'the distinctive index of civilization' ${ }^{35}$ Without security, the condition of human beings would be like that of savages or animals, limited to the present, without anticipation of future experience, and therefore without expectations. But, unlike Hume, for whom the insecurity and the uncertainty of the future could be remedied only by conventional or social behaviour, the anticipation of future consequences was for Bentham the very object of the human capacity for calculation. And the kind of pain that a legislator would endeavour to avoid by providing security for rational or calculating individuals was the pain of frustrated expectation, or the 'pain of disappointment'. ${ }^{36}$ The best insurance against that 'distinct and special evil' was the institution of property.

Third, it is remarkable that in his guidance to legislators regarding the rules that should be followed in determining the rights of property ownership, Bentham once again followed the criteria set out by Hume. Both followed Roman private law in their specification of the rules of ownership: actual or present possession, which Bentham included with occupation, prescription, accession and succession. But each rule, in Bentham's formulation, was based upon a calculation of the disappointments that would be avoided by following a particular rule and the pleasures of satisfied expectation or pleasures of wealth, as he more directly refers to it on occasion, ${ }^{37}$ which would follow from applications of the rule. As such, he rejected Hume's view that the rules of ownership derived from nothing other than the principles of the imagination. Bentham's campaign to rid the law of fictions made that kind of justification unacceptable. And his confidence in the capacity of legislators and judges to calculate the consequences of the applications of particular rules of laws made it possible for him to believe that a judge might weigh the pleasures and pains of two claimants to a certain property and award an appropriate amount to each:

Civil judges, who ... are obliged to give a decisive sentence on some one side, are often at a loss how to determine, and are necessitated to proceed on the most frivolous reasons in the world. ${ }^{38}$ 
Bentham's view was that the principle of utility, as he understood it, enabled a judge to weigh the pleasures and pains of both parties, and arrive at a more just distribution of goods:

the principle of caprice, without regard to the comparative amount of pains and pleasures, gives everything to one of the parties without paying any attention to the other. The principle of utility, anxious to reduce to the least term an inevitable inconvenience, weighs the two interests, seeks the means of reconciling them, and directs indemnities. $^{39}$

In his endeavour to complement justice as security with another dimension of justice, in the form of equity, Bentham may have drawn attention to a facet of Hume's theory that required amendment. But it must also be recognized that Hume's insistence upon the obligation to adhere to a conventional or uniform manner of implementing rules of law derived from an understanding of the problem of contingency or unpredictability in human affairs, which Bentham tended to ignore. Ultimately, there was something paradoxical in Bentham's insistence that although security was the end of law, the anguish of insecurity must be weighed by a legislator or judge in any given case - against the claims of other sources of pain and pleasure. The assumption of that capacity to calculate, given the limits of human reason, and the unpredictability of human affairs, could have no other effect, Hume would have said, than to reintroduce through the judiciary, conditions of insecurity that could have been avoided by adherence to a conventional form of behaviour.

Bentham considered sympathy to be a misleading principle inasmuch as it substituted the internal and subjective feelings or sentiments of individuals for the external and objective standard of utility. The principles of sympathy and antipathy fuel resentment and lead to punishments of greater severity than is warranted, necessary or useful. ${ }^{40}$ It is a question of whether this criticism of sympathy applies to Hume, for whom justice was an artificial not a natural virtue. Bentham's case against sympathy may apply more directly to Adam Smith's theory that justice has a natural origin in the resentment felt by the victim of injustice and in the sympathy felt by others that retaliation is appropriate.

Finally, Bentham, like Hume, was opposed to appeals to particular faculties of human nature to explain and justify human conduct. In An Introduction to the Principles of Morals and Legislation, Chapter 2, 
'of Principles Adverse to Utility', Bentham compiled a list of turns of phrase that:

consist all of them in so many contrivances for avoiding the obligation of appealing to an external standard, and for prevailing upon the reader to accept the author's sentiment or opinion as a reason and that a sufficient one for itself, the phrases different, but the principle the same. ${ }^{41}$

His list consisted of the following phrases: moral sense, common sense; understanding; rule of right; fitness of things; law of nature; law of reason, right reason, natural justice, natural equity, good order; truth; doctrine of election; repugnancy of nature. Most of these phrases, if not all, designate faculties or powers of the mind of the sort that Hume had dismissed as 'illusions' characteristic of 'the ancient philosophy'. Bentham's dismissal of these phrases and the internal monitors signified by them was in this respect consistent with Hume's treatment of the understanding and the passions.

V

Unlike Jeremy Bentham, James Mill had read Books I and II of Hume's Treatise with an appreciation for what he took to be Hume's originality. In his article 'Education', published in 1819 as a supplement to the Encyclopaedia Britannica, Mill wrote:

Mr. Hume perceived, much more distinctly than any of the philosophers who had gone before him, that to philosophize concerning the human mind was to trace the order of succession among the elementary feelings of man. He pointed out three great laws or comprehensive sequences, which he thought included the whole. Ideas followed one another, he said, according to resemblance, contiguity in time and place, and cause and effect. ${ }^{42}$

Mill also reserved for Hume the 'great discovery' that what are called our complex ideas are only a particular class of cases belonging to the same law - namely that of the succession of ideas; every complex idea being only a certain number of simple ideas that succeed each other so rapidly as not to be 'distinguished' without an effort of thought. 
Mill thought that Hume was much indebted to Hobbes's work on human nature; that it was Hobbes who had theorized the correspondence between ideas and impressions and the order in which they come to mind. Mill did not remark the distinctive character of Hume's theory of belief in this connection that the credibility of ideas depends upon the manner in which ideas make an impression on the mind. He allowed that Hume had 'made some brilliant developments in the philosophy of mind, but he did not advance very far in the general object'. ${ }^{43}$ The general object James Mill had in mind was education and how it could be made to contribute to human happiness. Fortunately, Hume was succeeded by Condillac and by Hartley, although Mill doubted either of them had read Hume's Treatise.

Mill would work up his own theory of the association of ideas in his Analysis of the Phenomena of the Human Mind (1829). His Analysis is notable for its reduction of mental phenomena to the simplest principles he could conceive. He reduced Hume's principles of the association of ideas and impressions to one principle: contiguity in place and time. ${ }^{44}$ Unlike Hartley, Mill had no theory of the 'vibratiuncles' or nerve endings that connect sensations or feelings: Mill retained Hume's theory that connections of ideas and impressions are marked by the vividness and frequency of the associations.

Later in the Analysis, Mill would explain: 'The Phenomena which have been classed under the titles of Moral Sense, Moral Faculty, Sense of Right and Wrong, Moral Affection, Love of Virtue, and so on, which are all names of similar import. ${ }^{45}$ As he explained these terms, they stand for nothing more than the pleasures or pains associated with acts of our own and of others. It is remarkable that what Mill described as acts prudence, bravery, justice and beneficence - Hume would have called qualities of character, virtues useful and agreeable to ourselves and others. Mill retained the categories of usefulness to ourselves and others: prudence and bravery are useful to ourselves, justice and benevolence are useful to others.

Mill was determined to reduce mental phenomena to the simplest explanations he could imagine: his reduction of virtues to acts useful to ourselves and others is a case in point. But one may recognize that he was employing categories of moral life that had been used by Hume. Opposite the title page of the Analysis, there are two epigraphs drawn from the writings of Dugald Stewart, which recommended the scientific study of human nature. Mill's work, however, has little in common with the philosophy of Dugald Stewart or with Thomas Reid or the editor of the works of Stewart and Reid, Sir William Hamilton. James McCosh, in 
The Scottish Philosophy, put it succinctly in his discussion of James Mill: 'Dugald Stewart's teaching seems to have exercised little influence in his mind except to suggest the order in which he takes up his topics. I suspect he derived more from Hume than from Stewart. ${ }^{36}$

Stewart had another pupil who remained much closer to him, personally and intellectually, than James Mill. Sir James Mackintosh (17651832) was one of several students of Dugald Stewart who wrote for The Edinburgh Review. ${ }^{47}$ In 1816 and in 1821, Sir James Mackintosh wrote reviews of the first and second parts of Stewart's Dissertation: Exhibiting the Progress of Metaphysical, Ethical and Political Philosophy. In Part II (1821), he reflected on the sceptical disposition of Hume:

the same character which disposes men to scepticism, may dispose them also to acquiesce in considerable abuses, ... ; they hope for little from human wisdom and virtue, and are rather secretly prone to that indolence and indifference which forbade the Epicurean sage to hazard his quiet for the doubtful interests of a contemptible race .... The sceptical temper of Mr. Hume may have thus insensibly moulded his political opinions. ${ }^{48}$

In 1830, Mackintosh published a sequel to Stewart's Dissertation, in which he considered the progress of ethical philosophy in the seventeenth and eighteenth centuries. He was not impressed by the progress made by moral philosophers in modern times; all, or almost all, had overlooked an important distinction between the object of moral judgement and the subjective feelings that prompt us to approve or disapprove the conduct of others and ourselves. It is a distinction, he said, that:

has seldom been made by moral philosophers; the difference between the two problems has never been uniformly observed by any of them; and it will appear in the sequel, that they have been not rarely altogether confounded by very eminent men, to the destruction of all just conception and of all correct reasoning in this most important, and, perhaps most difficult of all sciences. ${ }^{49}$

One would not be wrong in supposing that this was a fairly rash assertion on the part of Mackintosh; that a critic, predisposed to differ with him, might well fix upon it and produce citations from the writings of early modern moral philosophers where the distinction is very clearly and explicitly made. Such a critic would have a greater motive to do so if he found himself characterized as an unreflective follower of the 
master of a school where this important distinction had been neglected or suppressed. This confusion of the rightness or wrongness of actions with the feelings or motives that prompt us to approve or disapprove of those actions had its origins, Mackintosh believed, in the debates between Stoics and Epicureans in ancient times. It was not the Stoics who were guilty of this confusion, as Hume had advised Hutcheson, citing Cicero's sceptical reply to Cato in De Finibus, Book IV; in Mackintosh's mind, it was the Epicureans, who thought that utility or the happiness of oneself and others was both the object and the motive of moral action:

It may be said, indeed, that the Epicurean doctrine has continued with little change to the present day; at least it is certain that no other ancient doctrine has proved so capable of being restored in the same form among the moderns: and it may be added, that Hobbes and Gassendi, as well as some of our own contemporaries are as confident in their opinions, and as intolerant of scepticism as the old Epicureans. ${ }^{50}$

The contemporaries to whom Mackintosh alluded were Jeremy Bentham and his school: 'The disciples of Mr. Bentham are more like the hearers of an Athenian philosopher than the pupils of a modern professor ....' He said, 'They derive their opinions not so much from the cold perusal of his writings, as from familiar converse with a master from whose lips these opinions are recommended by simplicity, disinterestedness, originality and vivacity. ${ }^{51}$ Mackintosh was describing conversations of which he had no direct acquaintance; this was not the way Bentham talked, as those who knew Bentham more intimately would be quick to point out.

James Mill's A Fragment on Mackintosh: Being Strictures on Some Passages in the Dissertation by Sir James Mackintosh was published in 1835. It has been described as a work that is hypercritical and vituperative. John Stuart Mill was embarrassed by it, but thought that the substance of his father's arguments was basically sound. ${ }^{52}$ James Mill described his disposition as he wrote it in prefatory remarks to the reader. It was originally written, he said, in the form of letters to the author: 'And they were written with that severity of reprehension which the first feelings of indignation against an evil-doer inspire. ${ }^{53}$

It is remarkable that nowhere in a book of over 400 pages does Mill ever challenge Mackintosh's repeated characterization of Bentham and his school as Epicureans. 'Epicurean', it seems, was a term that did not present a problem for James Mill. He was more than ready to defend particular philosophers whom Mackintosh had described as Epicureans or 
worse. Mill devoted a chapter of his work to a defence of Hobbes on human nature. He took offence at Sir James's portrayal of Bernard Mandeville as 'the buffoon and sophister of the ale-house'. For Mill, Mandeville was describing human nature with candour and the conditions of economic flourishing in a commercial society with accuracy and with penetration. ${ }^{54}$ Helvétius was not as profound a philosopher as one might have wished, but he had made an important contribution to education. ${ }^{55}$ And James Mill thought that Hume was surely right when he wrote that:

Political writers have established it as a maxim, that in contriving any system of government, and fixing the several checks and controls of the constitution, every man ought to be supposed a knave, and to have no other end, in all his actions, than private interest. ${ }^{56}$

This was an insight that the framers of the American constitution, Hamilton and Madison, had very much in mind when they insisted upon an electoral college that would ensure presidents would be elected by those with some experience of government; unhappily, this arrangement has been modified over the centuries and decades in a manner that has produced a different, more controversial result.

\section{VI}

It must surely be the case that John Stuart Mill had Hume, among others, in mind, when he declared, memorably, that:

Those who know anything about the matter are aware that every writer, from Epicurus to Bentham, who maintained the theory of utility, meant by it, not something to be contradistinguished from pleasure, but pleasure itself, together with exemption from pain; and instead of opposing the useful to the agreeable or the ornamental, have always declared that the useful means these, among other things. $^{57}$

Hume could not have enunciated what is meant by the principle of utility in morals more clearly or more persuasively: this is what utility meant for Hume in the Treatise, Book III, and in An Enquiry Concerning the Principles of Morals, Section V: 'Why Utility Pleases'. And there are other contexts where, as Frederick Rosen has observed, J. S. Mill appears to have taken over arguments from Hume and Smith on the principles of political 
economy; on the logic of the sciences, where 'Mill uses some elements of Hume's approach (emphasis on liberty, moderation and character)', but with a different 'emphasis on social science rather than political science' and on national character; and, more generally, on the formation of Mill's conception of modern utilitarianism. ${ }^{58}$ But the differences in philosophical outlook between Hume and J. S. Mill remained remarkable; those differences turn on the character and consequences of scepticism.

In what must have been one of his earliest publications, a review of George Brodie's examination of Hume's History of England in The Westminster Review (October 1824, Volume II, 346-402), Mill perceived Hume to have been a romantic, who attached more importance to the pains and pleasures of a particular individual, Charles I, than to the greatest happiness of the greatest number. In his speculative reasoning, Hume had attempted to demonstrate that truth was unattainable and that, accordingly, entertainment could be the only object of writing. Consequently, Hume adopted an approach calculated to excite the emotions of his readers and, for this purpose, lingered over the misfortunes of a hero with whom the public could readily identify. And to this end, Hume falsified the historical evidence. He cultivated sympathy for the character of Charles I, while he denigrated the character of his parliamentary opponents. A more sympathetic reader of Hume's History might have answered that in the first edition of his History of Great Britain, under the House of Stuart, Hume was very critical of the arbitrary government of Charles. It was only after he discovered the still more arbitrary exercise of power by the Tudor monarchs that Hume judged that Charles had not departed from the customary behaviour of his predecessors.

In the first version of Mill's essay on Bentham in the Westminster Review (1838), Hume is described as 'the prince of dilettanti'; ;9 his scepticism naturally led him into Toryism in practice. If truth is unattainable, and thought is capable only of balancing one order of things against another, equally unsatisfactory, then the mind will prefer that order which has hitherto been compatible with private comfort. But in the reprint of the Bentham essay in Dissertations and Discussions (1859), this description of Hume is entirely deleted and, in its place, Hume is described as 'the profoundest negative thinker on record'. Mill continues:

the peculiarities of whose mind qualified him to detect failure of proof, and want of logical consistency, at a depth which French sceptics, with their comparatively feeble power of analysis and distraction stopt far short of, and which German subtlety alone could thoroughly appreciate, or hope to rival. ${ }^{60}$ 
Mill's appreciation of Hume's scepticism may have been brought to mind as he exercised his own talent for scepticism upon the philosophy of Sir William Hamilton. His pejorative characterization of French scepticism may reflect his increasing disenchantment with the philosophy of August Comte.

It is also worth remarking that Mill, like Hume, celebrated the virtue of humanity. But whereas Hume took the sentiment of humanity to be the foundation of morality in his An Enquiry Concerning the Principles of Morals, Mill took humanity to be the proper object of a religion. In his essay on 'Theism', Mill considered it highly appropriate that Christ had been chosen as 'a standard of excellence and a model of emulation ... as the pattern of perfection for humanity' ${ }^{61}$ Mill would place 'the Prophet of Nazareth ... in the very first rank of the men of whom our species can boast'. He thought that 'religion cannot be said to have made a bad choice in pitching upon this man as the ideal representative and guide of humanity'. ${ }^{62}$

Hume never expressed himself in this way. If there was a model of human nature to which he aspired, it was exemplified by Cicero in his relations with friends with whom he disagreed. Hume wrote to a Scottish critic of An Enquiry Concerning the Principles of Morals, James Balfour: 'Let us revive the happy times, when Atticus and Cassius the Epicureans, Cicero the Academic, and Brutus the Stoic, could all of them live in unreserved friendship together, and were insensible to all those distinctions, except so far as they furnished agreeable matter to discourse and conversation. ${ }^{63}$ Hume had composed, in the early 1750s, Dialogues Concerning Natural Religion. ${ }^{64}$ It was a work modelled on Cicero's On the Nature of the Gods: Hume's sceptic, Philo, was the teacher of Cotta, Cicero's sceptic; Hume's Stoic, Cleanthes, was the teacher of Balbus, Cicero's Stoic. The allusions would have been evident to Hume's readers. Hume withheld the book from publication in deference to the wishes of his friends, Adam Smith and Adam Ferguson, but he made provision to ensure its publication through his nephew, after Hume's death. James Boswell suggested to Hume that he would surely be happy to continue conversations with his friends in the afterlife. Hume replied that there is nothing he would enjoy more. The difficulty was that they, like Hume, did not believe in an afterlife.

\section{Notes}

1. David Hume, Enquiries Concerning Human Understanding and Concerning the Principles of Morals, reprinted from the 1777 edition with an Introduction and Analytical Index by L. A. Selby-Bigge (Oxford: Clarendon Press, 1975), 2.

2. David Hume, The Letters of David Hume, ed. J. Y. T. Greig (Oxford, 1932), Vol. II, 301. 
3. 'Un génie capable de tout approfondir, mais il écrivoit quelquefois a la hâte, et se contentoit d'effleurer les matières les plus graves. D 'ailleurs, on ne peut justifier cet Auteur d 'avoir trop aimé l'obscurité désolante du Pyrrhonisme': Jean-Pierre de Crousaz, Examen du Pyrrhonisme ancien et moderne (The Hague, 1733), 341; citing Chevalier Ramsay, Les Voyages de Cyrus, avec un discours sur la mythologie (1728), 9.

4. James Moore, 'Natural Law and the Pyrrhonian Controversy', in Philosophy and Science in the Scottish Enlightenment, ed. Peter Jones (Edinburgh: John Donald, 1988), 20-38.

5. Aberdeen University Library Mss 2131/2/III, 1-7: in David Fate Norton, 'Reid's Abstract of the Inquiry into the Human Mind', Philosophical Monographs 3 (1976): 125-32.

6. Thomas Reid, Essays on the Active Powers of Man, eds. Knud Haakonssen and James Harris (Edinburgh University Press, 2010), 301.

7. Reid, Essays on the Active Powers, 302.

8. Reid, Essays on the Active Powers, 304.

9. Reid, Essays on the Active Powers, 337.

10. Cicero, De Finibus Bonorum et Malorum, English trans. Horace Rackham (Cambridge, Mass.: Harvard University Press, 1921), IV, Ch. 17, 351-3.

11. Hume, Letters of David Hume, Vol. I, 304.

12. Hume, Letters of David Hume, Vol. II, 12.

13. See Christopher Brooke, Philosophic Pride: Stoicism in Early Modern Political Thought from Lipsius to Rousseau (Princeton University Press, 2012) for a lucid and even-handed narrative of this debate.

14. Adam Ferguson, Principles of Morals and Political Science (Edinburgh, 1792), Vol. II, 5.

15. David Hume, 'The Epicurean', in Essays, Moral, Political and Literary, ed. Eugene Miller (Indianapolis: Liberty Fund, 1985), 198.

16. Hume, Concerning the Principles of Morals, Appendix II: Of Self-Love.

17. Adam Ferguson, An Essay on the History of Civil Society, ed. Duncan Forbes (Edinburgh University Press, 1967), 13.

18. Ferguson, An Essay on the History of Civil Society, 13.

19. Ferguson, An Essay on the History of Civil Society, 13.

20. Ferguson, Principles, Vol. II, 511-12.

21. Ferguson, Essay on the History of Civil Society, 160.

22. Ferguson, Essay on the History of Civil Society, 242-3, 256.

23. John Hill Burton, Life and Correspondence of David Hume (Edinburgh, 1846), Vol. II, 503-4.

24. Jeremy Bentham, A Comment on the Commentaries and A Fragment on Government, eds. J. H. Burns and H. L. A. Hart (University of London: The Athlone Press, 1977), 440.

25. Jeremy Bentham, An Introduction to the Principles of Morals and Legislation, eds. J. H. Burns and H. L. A. Hart (Oxford: Clarendon Press, 1996), 12.

26. Bentham, A Fragment on Government, 440.

27. See the early mss: 'Pleasures and Pains. How measured', UC xxvii, 34: 'The idea of considering happiness as resolvable into a number of individual pleasures, I took from Helvétius; ... . The idea of estimating the value of each sensation by analyzing it into ... four ingredients I took from M. Beccaria: ... .', cited by Douglas Long, 'Utility and the Utility Principle', Utilitas 2/1 (1990): 20.

28. Francis Hutcheson, An Inquiry into the Original of Our Ideas of Beauty and Virtue in Two Treatises, ed. Wolfgang Leidhold (Indianapolis: Liberty Fund, 2008), Section 3, Article VIII, 164.

29. W. R. Scott, Francis Hutcheson: His Life, Teaching and Position in the History of Philosophy (Cambridge University Press, 1900, 272ff.; Robert Shackleton, 'The Greatest Happiness of the Greatest Number: The History of Bentham's Phrase', Studies in Voltaire and the Eighteenth Century, 90 (1972): 1461-82.

30. Hutcheson, Inquiry, Section 3, Article XI, 170.

31. Élie Halévy, The Growth of Philosophic Radicalism (Boston: Beacon Press, 1955), 52: 'although it is to Helvétius and Beccaria that Bentham owes ... his theory of penal law, it is undeniably to Hume that he owes the criticism of the notion of contract and the theory of the right of property'.

32. Bentham, A Fragment on Government, 426-38.

33. Bentham, 'Principles of the Civil Code', in The Theory of Legislation, ed. C. K. Ogden (London: Kegan Paul, 1931), 113.

34. Bentham, A Fragment on Government, 428-9.

35. Bentham, 'Principles of the Civil Code', in Theory of Legislation, 109.

36. Bentham, 'Principles of the Civil Code', in Theory of Legislation, 111. 
37. Bentham, Introduction to the Principles of Morals and Legislation, 43.

38. David Hume, A Treatise of Human Nature, eds. David Fate Norton and Mary J. Norton (Oxford: Oxford University Press, 2000), Bk 3, Pt 2, Ch. 6, Sect. 2, 340.

39. Bentham, 'Principles of the Civil Code', in Theory of Legislation, 163.

40. Bentham, Introduction to the Principles of Morals and Legislation, 29, 31.

41. Bentham, Introduction to the Principles of Morals and Legislation, 25-9.

42. James Mill, 'Education' (1819), in A Textbook for Utilitarians: James Mill: Articles in the Encyclopaedia Britannica: 1816-1823, ed. R. A. Fenn (Toronto, 1991), 222.

43. James Mill, 'Education', in Textbook for Utilitarians, 228.

44. James Mill, Analysis of the Phenomena of the Human Mind [originally 1829], with notes illustrative and critical by Alexander Bain, Andrew Findlater and George Grote, ed. with additional notes John Stuart Mill: in two volumes (London: 1878; reprinted New York: Augustus M. Kelley, 1967), 106-14.

45. James Mill, Analysis, Vol. II, 280.

46. James McCosh, The Scottish Philosophy (1875; reprinted Hildesheim: Georg Olms, 1966), 395.

47. Donald Winch, 'The System of the North: Dugald Stewart and His Pupils', in That Noble Science of Politics, Stefan Collini, Donald Winch and John Burrow (Cambridge University Press, 1983), 45-7.

48. Sir James Mackintosh, 'Stewart's Introduction to the Encyclopaedia', Edinburgh Review 36/71 (1821: October): 260.

49. Sir James Mackintosh, The Miscellaneous Works of the Right Honourable Sir James Mackintosh (Boston, 1854), 87.

50. Mackintosh, Miscellaneous Works, 104.

51. Mackintosh, Miscellaneous Works, 87.

52. John Stuart Mill, Autobiography (London: Oxford University Press, 1958), 171.

53. James Mill, A Fragment on Mackintosh: Being Strictures on Some Passages in the Dissertation by Sir James Mackintosh (London, 1870), iii.

54. James Mill, Fragment on Mackintosh, 58-63.

55. James Mill, Fragment on Mackintosh, 63-8.

56. Hume, 'Of the Independence of Parliament', in Essays, Moral, Political and Literary, cited by James Mill, Fragment on Mackintosh, 279-81.

57. John Stuart Mill, 'Utilitarianism', in Essays on Ethics, Religion and Society, ed. J. M. Robson (Toronto: University of Toronto Press, 1969).

58. Frederick Rosen, Mill (Oxford University Press, 2013), 151, 259, 264, 266.

59. J. S. Mill, Collected Works of John Stuart Mill, 33 vols, gen. ed. J. M. Robson (London/Toronto: Routledge and Kegan Paul/University of Toronto Press, 1963-1991), X, 80 variant $q-q 38$.

60. J. S. Mill, Dissertations and Discussions: Political, Philosophical, and Historical, Reprinted Chiefly from the Edinburgh and Westminster Reviews, 2 vols (London: J. W. Parker and Son, 1859), 335.

61. J. S. Mill, 'Three Essays on Religion', in Collected Works, X, 487.

62. Mill, 'Three Essays on Religion', X, 488.

63. Hume, Letters of David Hume, Vol. I, 173

64. David Hume, Dialogues Concerning Natural Religion (Edinburgh, 1779).

\section{Bibliography}

Bentham, Jeremy. A Comment on the Commentaries and A Fragment on Government. Edited by J. H. Burns and H. L. A. Hart. University of London: The Athlone Press, 1977.

Bentham, Jeremy. An Introduction to the Principles of Morals and Legislation. Edited by J. H. Burns and H. L. A. Hart. Oxford: Clarendon Press, 1966.

Bentham, Jeremy. The Theory of Legislation. Edited with an introduction and notes by C. K. Ogden. London: Kegan Paul, 1931.

Brooke, Christopher. Philosophic Pride: Stoicism in Early Modern Political Thought from Lipsius to Rousseau. Princeton University Press, 2012.

Burton, John Hill. Life and Correspondence of David Hume. Edinburgh: 1846.

Cicero. De Finibus Bonorum et Malorum. English translation by Horace Rackham. Cambridge, Mass.: Harvard University Press, 1921.

Collini, Stefan, Winch, Donald and Burrow, John. That Noble Science of Politics. Cambridge University Press, 1983. 
Crousaz, Jean-Pierre de. Examen du Pyrrhonisme, ancien et moderne. The Hague, 1733.

Fenn, Robert A. (ed.). A Textbook for Utilitarians: James Mill: Articles in the Encyclopedia Britannica: 1816-1823. Toronto: 1991.

Ferguson, Adam. An Essay on the History of Civil Society. Edited by Duncan Forbes. Edinburgh University Press, 1967.

Ferguson, Adam. Principles of Moral and Political Science. Edinburgh: 1792.

Halévy, Élie. The Growth of Philosphic Radicalism. Boston: Beacon Press, 1955.

Hume, David. Dialogues Concerning Natural Religion. Edinburgh, 1779.

Hume, David. Enquiries Concerning Human Understanding and Concerning the Principles of Morals. Edited with an Introduction and Analytical Index by L. A. Selby-Bigge. Oxford: Clarendon Press, 1975.

Hume, David. Essays, Moral, Political and Literary. Edited by Eugene F. Miller. Indianapolis: Liberty Fund, 1985.

Hume, David. The Letters of David Hume. Edited by J. Y. T. Greig. Oxford: Clarendon Press, 1932.

Hume, David. A Treatise of Human Nature. Edited by David Fate Norton and Mary J Norton. Oxford: Oxford University Press, 2000.

Hutcheson, Francis. An Inquiry into the Original of Our Ideas of Beauty and Virtue in Two Treatises. Edited with an Introduction by Wolfgang Leidhold. Indianapolis: Liberty Fund, 2008.

Long, Douglas. 'Utility and the Utility Principle', Utilitas 2/1, 1990.

Mackintosh, Sir James. The Miscellaneous Works of the Right Honourable Sir James Mackintosh. Boston, 1854.

Mackintosh, Sir James. 'Stewart's Introduction to the Encyclopedia', Edinburgh Review 36/71 (1821): 260.

McCosh, James. The Scottish Philosophy. London, 1875.

Mill, James. A Fragment on Mackintosh: Being Strictures on Some Passages in the Dissertation by Sir James Mackintosh. London, 1870 [original 1835].

Mill James. Analysis of the Phenomena of the Human Mind, in two volumes. London, 1878 [1829].

Mill, John Stuart. Autobiography. London: Oxford University Press, 1958.

Mill, John Stuart. Collected Works of John Stuart Mill, 33 vols. General editor J. M. Robson. London/ Toronto: Routledge and Kegan Paul/University of Toronto Press, 1963-1991.

Mill, John Stuart. Dissertations and Discussions: Political, Philosophical, and Historical, Reprinted Chiefly from the Edinburgh and Westminster Reviews, 2 vols. London, J. W. Parker and Son, 1859.

Mill, John Stuart. 'Utilitarianism'. In Essays on Ethics, Religion and Society, edited by J. M. Robson. Toronto: University of Toronto Press, 1969.

Moore, James. 'Natural Law and the Pyrrhonian Controversy'. In Philosophy and Science in the Scottish Enlightenment, edited by Peter Jones. Edinburgh: John Donald, 1988.

Norton, David Fate. 'Reid's Abstract of the Inquiry into the Human Mind', Philosophical Monographs, 3, 1976.

Reid, Thomas, Essays on the Active Powers of Man. Edited by Knud Haakonssen and James Harris. Edinburgh University Press, 2010.

Rosen, Frederick, Classical Utilitarianism from Hume to Mill. London: Routledge, 2003.

Rosen, Frederick, Mill. Oxford University Press, 2013.

Scott, W. R. Francis Hutcheson: His Life, Teaching and Position in the History of Philosophy. Cambridge University Press, 1900.

Shackleton, Robert. 'The Greatest Happiness of the Greatest Number: The History of Bentham's Phrase', Studies in Voltaire and the Eighteenth Century, 90 (1972): 1461-82 


\section{5 \\ Bentham on 'Hume's Virtues'}

José L. Tasset

\section{Introduction}

Among scholars of utilitarianism, it is quite common to discuss Hume's influence on Bentham. It is also often argued that the founder of classical utilitarianism's admiration for the Scottish thinker diminished over time, mainly due to Bentham's tendency to believe that Hume was not clearly or completely a utilitarian.

A detailed and comprehensive study of the relationship between the two thinkers has yet to be made. Nor has there been as an exhaustive analysis of the possible role played by David Hume in what has been referred to as 'The Invention of Utilitarianism'. ${ }^{1}$

This paper focuses on a specific aspect of the relationship between Hume and Bentham: the critical reading that Bentham carries out of the theory of virtues proposed by David Hume from Bentham's classical utilitarianism assumptions.

After providing an overview of the basic elements comprising David Hume's theory of virtues, this paper analyses Bentham's criticisms. In its conclusion, it defends the compatibility of Hume's theory with some of the essential assumptions of classical utilitarianism - as well as the broad impact that Hume's position might have had on the development of classical utilitarianism. 


\section{A scheme of Hume's theory of virtues}

\section{Aims of the theory}

David Hume formulated his theory of the virtues both in his Treatise of Human Nature ${ }^{2}$ and in the Enquiry Concerning the Principles of Morals. ${ }^{3}$ Further considerations are also found in some of his essays. ${ }^{4}$

I argue that the ultimate goal of this theory is to construct an explanation of the way in which the social and political institutions that make human social life possible have emerged, been maintained and gradually developed. In Hume's theory, the distinction between natural and artificial virtues occupies a crucial place. ${ }^{5}$ Moreover, I believe that the idea of the different role utility plays in the genesis and justification of both types of virtue is fundamental to his theory.

\section{The definition of virtue}

A virtue in Hume's words is a character or action (object) that demands approval.

In Section 9 of the Enquiry Concerning the Principles of Morals, under the general title of 'personal merit', Hume succinctly defines a virtue as: '.. the possession of mental qualities, useful or agreeable to the person himself, or to others'. ${ }^{6}$

On the other hand, a key thesis of Hume's ethics is that morality is determined by sentiment. Later, in the same work, Hume adds a complementary definition of virtue by insisting on its emotional aspects: ' ... whatever mental action or quality gives a spectator the pleasing sentiment of approval...'?

Vice would simply be that which offers the opposite feeling. ${ }^{8}$

The description offered in the Treatise is consistent with this, although more developed in its link to feelings of pleasure and pain: 'Every quality of the mind is denominated virtuous which gives pleasure by the mere survey, as every quality which produces pain, is called vicious. ${ }^{9}$

According to this explanation by Hume, virtues or vices will be those qualities and tendencies (of action) that usually give rise to pleasure or pain in the observer, without having a relationship between them that could alter objective judgement.

Together with this, Hume adds that there are a number of characteristics or criteria that lead us to recognize something as a virtue. In particular, he speaks of 'four different sources' (or foundations) ${ }^{10}$ of virtue. ${ }^{11}$ 
A trait of character or, indirectly, an action, can be considered virtuous or vicious, by considering whether it is:

\begin{tabular}{llll}
\hline Qualities & Agreeable & To ourselves & EPM: 3 \& 5 \\
& & To others & EPM: 6 \\
& Useful & To ourselves & EPM: 8 \\
& To others & EPM: 7 \\
\hline
\end{tabular}

Throughout Hume's work, we can find many and varied lists of these four kinds of virtues. For example, they are specified in the Treatise: (a) 'useful to others': generosity, humanity, bravery, beneficence; (b) 'useful to oneself': good sense, prudence, temperance, frugality, industry, assiduity, enterprise, dexterity; ${ }^{12}$ (c) 'agreeable to others': scalability, wit, ingenuity, cheerfulness; and (d) 'agreeable to oneself': courage, good humour and philosophical tranquillity. Some virtues fall into several categories. For example, 'Benevolence' is both 'useful to others' and 'agreeable to oneself'. Others are both 'useful' and 'agreeable to ourselves': courage, intrepidity, ambition, love of glory; ${ }^{13}$ and constancy, fortitude and magnanimity. ${ }^{14}$ Finally, there are virtues that are both 'useful' and 'agreeable to others': generosity, humanity, compassion, friendship, fidelity, zeal, disinterestedness and liberality. ${ }^{15}$

Scholars' attention is usually focused on the qualities useful to others, since these would include artificial virtues - that is, justice and everything that Hume called 'social virtues'.

It should be noted here that moral approval clearly takes into account actions and their practical consequences, but only to the extent that they reveal the motives that direct and lead to them, which will be the direct objects of evaluation in reality. ${ }^{16}$

And here, in the motives for action, is where natural and artificial virtues differ.

\section{Natural or artificial virtues and utility}

In the case of a natural virtue, there are in us (a) natural dispositions of behaviour towards them, and (b) natural tendencies towards the related approval of these same dispositions and their objective, the natural virtues. ${ }^{17}$

In contrast, artificial virtues do not possess natural motives, predispositions or tendencies, either towards their fulfilment or towards their approval. ${ }^{18}$ 
The solution to the very complex problem of the motive for justice (as an artificial virtue) will require a special analysis of Hume. An evolutionary dimension must be introduced to explain the genesis and approval of this virtue.

Although this is perhaps the richest and most innovative element of Hume's entire theory of virtues, we are not going to dwell specifically on it. ${ }^{19}$ We are more interested, at this moment, to show only that there are two types of virtues in Hume and that these originate from distinct passions as well as from a different perception of their utility, as we shall see from this point on.

Without going into detail, Hume's conclusion about the process leading to the recognition of an object (of the mind) as a virtue (or vice) will be that a natural virtue comes from a natural motive, while an artificial virtue comes from an artificial motive. This is a conventional process that will generate, through education and above all through the experience of its beneficial consequences or its utility, a feeling and inclination (motive) favourable to its practice and approval.

In the case of natural virtues, utility is also present, but it is always direct, the product of a simple action. It can thus be the object of a natural, direct passion, produced by a pattern of simple behaviour. ${ }^{20}$

An example may serve to clarify the foundation of natural passions. We do not need conventions that generate in us favourable motives to help our direct relatives. And if we do not need or demonstrate them, we all immediately know - because the direct passion of love is lacking - that our behaviour reveals an evident vice of 'ingratitude' or 'disloyalty'. ${ }^{21}$

On the other hand, the utility of an artificial virtue is always indirect. Furthermore, it usually entails accomplishing complex actions, generally of a collective nature. Thus, the motive for its realization and approval cannot come from a simple, and in that sense 'natural', provision. It will require a complex pattern of action, most likely of a collective, and not an individual, character. For the sake of simplicity, it will need an artificial pattern of behaviour. ${ }^{22}$

Thus, the natural virtues have a direct utility, and the artificial ones an indirect utility.

\section{How must we interpret the Humean distinction between natural and artificial virtues?}

Here we come to a central issue in interpreting Hume. Can it simply be held that this distinction between the two kinds of virtue and their different types of utility can correspond to the contemporary distinction 
between act utilitarianism and rule utilitarianism? My general opinion on this crucial issue is that it is problematic to attribute to Hume a clear and conclusive form of twentieth-century ethics.

As Roger Crisp rightly points out, in order to understand Hume's response, we have to ask the questions that he asked himself and in the terms in which he asked them. ${ }^{23}$ We must focus, therefore, on Hume's problem, which is the slow and complex emergence of artificial structures and institutions (institutional evolution) based on natural motives that allow human beings, first of all, to survive and then to make progress. In that way, we will understand his theory and clarify his position in a more suitable way than if we try to make them correspond exactly to some contemporary form of utilitarianism.

Even so, this distinction between natural and artificial virtues comes not only from the fact that the utility of the former is direct, whereas that of the latter is indirect. It also comes from the way the former functions only in the immediate social sphere, while the latter establishes itself and is formed mainly in relation to the distant (and so not immediate) social context.

Because of the importance Hume gives to artificial virtues, he may at times seem to underestimate the importance of the natural virtues. He seems to forget his project of articulating the natural and artificial-conventional form of virtue. In fact, this is not so, despite the dominant tone of Hume's exposition. Hume does not really hold the view that there is no such thing as a 'natural morality'. In his opinion, this kind of morality does exist. This morality would entail directly approving of certain qualities or actions. The problem is that these qualities all refer to the 'near dominion'. Outside of this, they lose all of their meaning; their strength and influence are greatly dissipated. Now, since a large part of a person's life develops outside of this immediate realm, the so-called 'natural morality' will explain only a small part of the 'moral phenomenon'. It will need an extension of its limits that can no longer be as 'natural' as in its application to immediate behaviour.

In this respect, Hume's conclusion, therefore, seems to be that, given the mental and passionate nature of the human constitution, the virtues will not be able to fulfil their role of establishing social order, once societies become more complex, if they do not transform their natural bases through an artificial process. They must be adjusted to new exigencies and necessities.

In summary, it may be said that, according to Hume, the natural and artificial virtues are distinguished, first, by the different type of utility that forms the basis for their approval and practical realization. 
Second, they will be distinguished by the different social environments in which they are exercised and in relation to which they have influence and validity. For the next level, we need no more than the natural virtues, and the extension of human life. Social policy must generate artificial virtues, the main one being justice. Natural virtues form the basis for their artificial counterparts, which in turn develop these natural virtues in a progressive and complex way. ${ }^{24}$

\section{Bentham's criticism of the Humean theory of virtues}

Bentham formulated the basis of his position on Hume's theory of virtues, and then dealt with the place of utility within it, in a well-known fragment of his first published work, A Fragment on Government (1776).

Bentham begins this text by pointing out the decisive character of the Humean critique of contractualism. This is crucial for understanding his reception of Hume's thought:

As to the Original Contract ..., a few pages, perhaps, may not be ill bestowed in endeavoring to come to a precise notion about its reality and use. The stress laid on it formerly, and still, perhaps, by some, is such as renders it an object not undeserving of attention. I was in hope, however ..., that this chimera had been effectually demolished by Mr HUME ... I think we hear not so much of it now as formerly. The indestructible prerogatives of mankind have no need to be supported upon the sandy foundation of a fiction. ${ }^{25}$

Bentham then gives a detailed account of his views on the different aspects of Humean thought, making them correspond to the three books of the Treatise (knowledge, passions and morality). He shows himself as being very critical about Hume, especially with what he considers the radical sceptical implications of his epistemology, contained in Book I of the Treatise: ${ }^{26}$

Our Author [Bentham is criticizing the legal ideas by Sir William Blackstone, JLT], one would think, had never so much as opened that celebrated book: of which the criminality in the eyes of some, and the merits in the eyes of others, have since been almost effaced by the splendour of more recent productions of the same pen. The magnanimity of our Author scorned, perhaps, or his circumspection feared, to derive instruction from an enemy: or, what is still more 
probable, he knew not that the subject had been so much as touched upon by that penetrating and acute metaphysician, whose works lie so much out of the beaten track of Academic reading. But here, as it happens, there is no matter for such fears. Those men, who are most alarmed at the dangers of a free enquiry; those who are most intimately convinced that the surest way to truth is by hearing nothing but on one side, will, I dare answer almost, find nothing that which they deem poison in this third volume. I would not wish to send the Reader to any other than this, which, if I recollect alright, stands clear of the objections that have of late been urged, with so much vehemence, against the work in general. [By Dr BEATTIE, in his Essay on the Immutability of Truth. Note by Bentham.]. As to the two first [Books I and II from Treatise, JLT], the Author himself, I am inclined to think, is not ill disposed, at present, to join with those who are of opinion, that they might, without any great loss to the science of Human Nature, be dispensed with. ${ }^{27}$ The like might be said, perhaps, of a considerable part, even of this [Book III of Treatise, JLT]. But, after all retrenchments, there will still remain enough to have laid mankind under indelible obligations. ${ }^{28}$

Hume's Benthamite evaluation ends with a critique of Hume from Helvétius and the well-known quotation about the profound impact that Hume's theory of justice had on Bentham:

That the foundations of all virtue are laid in utility, is there demonstrated, after a few exceptions made, with the strongest force of evidence: but I see not, any more than Helvétius saw, what need there was for the exceptions. ${ }^{29}$... For my own part, I well remember, no sooner had I read that part of the work which touches on this subject, than I felt as if scales had fallen from my eyes. I then, for the first time, learnt to call the cause of the people the cause of Virtue. ${ }^{30}$

Subsequently, this criticism is further developed in Appendix ' $\mathrm{C}$ ' from Bentham's Deontology, entitled 'Hume's Virtues' ${ }^{31}$ as well as in his article 'Utilitarianism'. ${ }^{32}$

When he analyses Humean thought in all of these texts, Bentham's position is ambivalent. This is particularly clear in the extensive appendix of Deontology. Hume is harshly criticized, but at the same time, Bentham also expresses admiration for Hume's distinction between impressions and ideas. ${ }^{33}$ 
In the general version of his criticism, Bentham suggests that Hume is ambiguous about the concept of utility. ${ }^{34} \mathrm{He}$ sometimes considered it to be synonymous with 'conducive to happiness' ${ }^{35}$ and, on other occasions, as 'conduciveness to the end or purpose proposed', "whatsoever may happen to be that same end or purpose'. ${ }^{37}$

As a result of this overall discrepancy (Frederick Rosen has shown that this does not affect the clear utilitarian character of Hume's ethic), ${ }^{38}$ Bentham suggests the following major problems in Hume's virtue theory.

First, Hume does not properly define what virtue is, ${ }^{39}$ so that it may not be distinguished from other, related mental contents: ${ }^{40}$

Pleasures, pains, desires, emotions, affections, passions, interests, virtues, vices, talents and other psychological entities are brought together ... but the whole group in a state of the most perfect confusion and without any attempt to show in what relationship they stand to one another. ${ }^{41}$

The second of Bentham's criticisms of Hume has two parts, though they are interrelated: (a) by not properly defining virtue, Bentham accuses Hume of confusing natural talents with virtues; and (b) to the extent that Hume's view assimilates virtues and natural talents, it tends to forget that virtues are not related to intelligence, but to will, thus failing this condition. In the case of natural virtues, Hume's theory would collapse because of its starting point. ${ }^{42}$

Before evaluating this critique, it is necessary to have an overview of the technical terminology used by Hume. Bentham believes that Hume is incorrect in conceiving virtues as being related to intelligence, since, in his judgement, a virtue is always related to will. Bentham misunderstands Hume's use of 'mind', which refers to the whole set of mental acts. It is not limited to intelligence. From a Humean point of view, the will forms part of the structure of our 'mind', just as much as any feeling or passion.

Beyond this, the overall understanding of Hume's purpose seems to be far too restricted. The general title that appears next to some pages of the original manuscript of this work by Bentham, 'Hume's Virtues and J. Bentham's Intellectual Faculties', ${ }^{43}$ offers us a clue about what concerned Bentham. This is clearly different from what concerned Hume. Bentham thought about the possible relationship, distinction and/or confusion between Hume's virtues and what Bentham simply considered to be natural intellectual faculties.

This marginal note shows that Bentham does not perceive the central importance of Hume's distinction between the natural and the 
artificial, to the extent that, to face Hume and reveal his own originality, for Bentham, virtue comes to oppose any kind of natural quality: " "Virtue" ... denotes a factitious quality [caused by the subject, produced, JLT], in contradiction to a natural one'; ${ }^{44}$ and 'In so far as factitious, it is the result of will, an exercise of the attention fixed upon the subject, and having an end in view. In the first instance, requiring a sacrifice of present to future contingent good is required and is accompanied with self-denial, which supposes more or less uneasiness. ${ }^{45}$

Later, as if this were not sufficiently clear, he insists: ' ... there is no virtue where there is no struggle. Virtue implies a victory over something. ${ }^{46}$

Along with the denial of their possible natural character, Bentham also fully denies their potentially intellectual nature:

Every virtue is a moral quality in contradistinction to an intellectual; i.e. a quality that belongs to the volitional, not to the intellectual department of the human frame: a quality which is the result of the exercise given to the will, not of the state and condition of the understanding ...47

Finally, and most importantly, since Hume does not ascribe a foundational character to utility, Bentham considered his overall thesis on virtues to be contradictory. It first connected virtues with utility, and subsequently suggested ('a few exceptions made') that not all virtues derive their value and approval from utility. ${ }^{48}$

\section{Beyond Bentham: utility, virtue and morality}

The criticism of Bentham from the previous section mainly focuses on the fact that utility is not the only basis in considering a quality of character (of the mind, remember what Hume says), or, through an extension of actions derived from it, as constituting a virtue or deserving the label 'virtuous' (or vicious). ${ }^{49}$

Bentham also seems to reject the possible natural character of some virtues, and also their hypothetical and sometimes predominantly involuntary character. In a somewhat confused way, he indicates that they are not related to the intellect (apparently involuntary, for him a mere state), but rather, to the will itself (a process, an activity). ${ }^{50}$

We shall briefly discuss a possible answer to these two minor accusations in Humean terms. Then, in a necessarily brief manner, we shall 
confront the Humean arguments with the somewhat peculiar main accusation that Hume is utilitarian in his theory of virtues, but not sufficiently rigorous or consistent.

Other critiques against attributing a utilitarian position to Hume are imaginable and have been formulated from contemporary ethics. However, the global question of whether Hume's ethics and political philosophy can be linked to or disassociated from classical utilitarianism is a different and broader question from the one I raise here: How weighty are the criticisms that Bentham directed to him? And, therefore, is it possible to read, or not, a utilitarian basis in Hume's theory of virtues?

From the exposition we have made in the previous section, it seems correct to infer that, together with the crucial fact that utility in Hume is not the sole foundation of virtue, Bentham argues against Hume that a virtue can ever be natural or involuntary.

It is true that Hume does not establish a clear difference between natural capacities and moral virtues, which would be a logical consequence of his definition of virtue. Moreover, Hume would refuse to distinguish between them based on whether his/her possessor holds them voluntarily or not. ${ }^{51}$

Against Bentham's view, Hume might simply have argued, for example, in the first place, that many virtues, such as strength of mind, are involuntary. ${ }^{52}$

On the other hand, the Epicurean root thesis, which links virtue or vice with pleasure or pain, felt from 'the general consideration of any quality or character' (or its derived actions, I add), may cause many virtues to be involuntary. These could cause pain or pleasure regardless of whether they are voluntary or not.

In view of this fact, it is necessary to ask what the key element is in evaluating something as a virtue, if it is not its voluntary character (which, on the other hand, as a freedom of absolute indeterminacy, Hume thought did not exist). Nor, of course, is it its natural character. As Roger Crisp rightly points out: 'It is, then, the durability or the steadiness of moral qualities that leads to their being the primary concern of ethical judgements. ${ }^{53}$

Having established this, from Hume's point of view we are already in a suitable position to answer the key question about any theory of virtue: 'What qualities should we possess?' Or even 'Into what kind of person (from our qualities) should we develop?' Here, we believe, Hume's proposal is totally compatible with utilitarianism. Moral qualities are justified, regardless of whether they are natural or artificial, voluntary or not. That is, we can certainly establish that we must possess them, insofar as they promote utility. 
And this is what can be said in Humean terms concerning the first part of Bentham's criticism - the one in which he stated emphatically that a virtue could only be artificial and voluntary.

More complex is the answer to the other Benthamite critique, namely, that utility does not have a foundational role in David Hume's theory of virtues.

It might be appropriate, however, to point out that, even though Bentham had specific criticisms of certain ideas contained in Hume's theory of virtue, we could still say that Bentham would accept the thesis in which Hume turns utility into the foundation of virtue as social practice. ${ }^{54}$

Bentham could really only agree in a general way with Hume when he says in the Enquiry:

It appears to be matter of fact, that the circumstance of utility, in all subjects, is a source of praise and approbation: That it is constantly appealed to in all moral decisions concerning the merit and demerit of actions: That it is the sole source of that high regard paid to justice, fidelity, honour, allegiance, and chastity: That it is inseparable from all the other social virtues, humanity, generosity, charity, affability, lenity, mercy, and moderation: And, in a word, that it is a foundation of the chief part of morals, which has a reference to mankind and our fellow creatures. ${ }^{55}$

Regardless of Hume's specific meaning of utility, which Bentham considers, as we have seen, to be essentially ambiguous, we must analyse here the question of the role that Hume gives it in his foundation of virtue. That, it seems, is the central point of discrepancy between Hume and Bentham. If we go back to Hume's text, we see two things clearly: (a) on the one hand, he asserts that utility is always a source of approval; and (b), on the other hand, he also asserts that not all approval comes from utility.

Let us analyse the first thesis, which, though it seems obvious, is of a deep transcendence. As Fred Rosen points out from the commentary on an anonymous review of Hume's arguments - published in 1753, before Bentham's criticism - Hume explained moral approval as a bond between utility and pleasure, that is, precisely in the same terms found in the basic thesis of classical utilitarianism. ${ }^{56}$

Now, as Bentham will do later, the anonymous 1753 reviewer draws attention to the fact that, although utility is the foundation for much of virtue, it does not embrace everything that Hume regards as virtue.

That is to say, on the one hand, Hume would be embracing, from his Epicurean roots (shared with Bentham), the basic thesis of what will later 
be defined as classical utilitarianism (utility $\Rightarrow$ approbation $\Rightarrow$ pleasure). Nevertheless, he would as well be proposing an implicit criticism of this same principle: there are also sources of approval connected with pleasure, which are different from utility.

Thus, Hume's own fundamental text quoted at the beginning of this section serves to connect Hume to Jeremy Bentham. It also serves to separate them, since it clearly shows that Hume always avoids falling into what might be called a utilitarian monism.

In that text, we see that Hume says utility is ' $a$ source' but not 'the only source' of moral approval. It is true that he goes on to say it is 'the sole source ...' ' with respect to virtues such as justice (and others). Not all virtues are included here, although justice occupies a central place in Hume's theory of virtues. Consistent with its non-reductive or pluralistic approach, the text also points out that it is 'inseparable from all other social virtues'. However, it is not dominant or exclusive to other possible factors of approval. Finally, while the text clearly states that 'it is [a] foundation of most morals', in no place does it say it is 'the sole foundation'. We must realize that he does not say 'of all morals', but, certainly, of most: those that are related to humanity, that is, to interaction with others.

In the end, the pertinent question is why Hume introduces all of these limiting considerations to utility's role, if the novel approach in Inquiry comes precisely from the fact that he has first linked moral approval with pleasure, and then pleasure with utility. In my view, Hume is here applying his famous argument about the limited possibilities of reason in ethics and the predominant, non-exclusive and non-excluding role of passions within the domain of morality.

In this way, Hume would be refraining from asserting, I think consciously, that utility (in his theory, in fact, reason or what is sometimes called 'considerations of utility') is the sole foundation of all morality; that morality can be a simple calculation of the utility of motives, of character and even, finally, and in a derivative way, of actions. This aspect of morality is crucial, necessary or fundamental, but it is not the only one, and should not be, at least from the point of view of Hume's consideration of the facts about morality.

I believe, therefore, that Jeremy Bentham's rejection, though moderated, of Hume's theory of virtues (probably the origin of Bentham's estrangement from Humean views) can be explained by how Bentham perceived Hume's rejection of utility as the sole foundation of our sentiment of approval. However, I also feel that Bentham was mistaken in 
confronting Hume's position in a tangential way by insisting on the fact that its details were confused, or subject to criticism. At the same time, Bentham avoids entering into a direct discussion with Hume's possible central assumption that there is a discrepancy with classical utilitarianism. He asserted that morality is a complex phenomenon in which considerations of utility are crucial. Nevertheless, other considerations, such as other sources of value, are not excluded. These can be as broad as the complex phenomenon of human morality.

\section{Notes}

1. Stephen L. Darwall, 'Hume and the Invention of Utilitarianism', in Hume and Hume's Connexions, eds. M. A. Stewart and John P. Wright (Edinburgh: Edinburgh University Press, 1994), $58-82$.

2. In what follows I will quote the Treatise using the standard abbreviation T.book.section.paragraph; the text is taken from David Hume, A Treatise of Human Nature, eds. David Fate Norton and Mary J. Norton, Oxford Philosophical Texts (Oxford: Oxford University Press, 2000).

3. In what follows I will quote from the Enquiry Concerning the Principles of Morals using the standard abbreviation EPM, part.section.paragraph; when necessary, I have taken texts from David Hume, An Enquiry Concerning the Principles of Morals, a Critical Edition, in The Clarendon Edition of the Works of David Hume, ed. Tom L. Beauchamp (Oxford: Oxford University Press, 1998). Although differences exist between Treatise and Enquiry, the general approach taken by Hume, in my opinion, remains constant. However, the details of the theory are discussed with much greater precision in the Treatise.

4. He also discussed the question of different classical models of virtue in the famous 'Four Essays on Happiness' ('The Sceptic', 'The Platonist', 'The Epicurean', 'The Stoic'), although there he assesses not only the ethical merits of models, but also the theoretical ones. My study of these four essays is found in José L. Tasset, David Hume: Disertación sobre las pasiones y otros ensayos morales (Barcelona: Anthropos, 2004), and the corrected reprint of my critical Spanish edition of these four essays in José L. Tasset, Hume: Obras (Madrid: Editorial Gredos, 2012).

5. For a simple statement of the general features of Hume's theory of virtues, see Kenneth R. Merrill, Historical Dictionary of Hume's Philosophy, Historical Dictionaries of Religions, Philosophies, and Movements (Lanham, Md., [etc.]: Scarecrow Press, 2008), 269ff. There is a huge amount of literature on the theory of virtues by Hume: for example, Dan O'Brien, 'Hume and the Virtues', in The Continuum Companion to Hume, eds. Alan Bailey and Dan O'Brien (London: Continuum, 2012), 288-302. However, as noted in the introduction, the aim of this paper is not to provide a detailed discussion of this theory and all its intermediary theses, but, rather, to review its schematic presentation to contrast it with its reading by Jeremy Bentham, so that the latter can be assessed.

6. EPM.9.1.1.

7. EPM.app.1.10.

8. Also in EPM.app.1.10. When Hume talks about 'mere survey' or 'mere contemplation' as a characteristic element of moral judgement, I interpret it as Hume wanting to emphasize that moral judgement has another basis aside from judgement that is based merely on self-interest, a selfish view. Mere contemplation leads us to judge from an impartial point of view, since our interests are not at stake. However, Hume never said that impartiality was completely opposed to interests - although he did recognize that interests at stake are a controllable element for generating or producing a fair judgement. In any case, the absence of initial interested involvement facilitates impartiality. On the possible differences between Humean and utilitarian impartiality, see Roger Crisp, 'Hume on Virtue, Utility, and Morality', in Virtue Ethics, Old and New, ed. Stephen Mark Gardiner (Ithaca, N.Y.: Cornell University Press, 2005), $175 \mathrm{ff}$.

9. T.3.3.1.30. 
10. Here Hume is no longer speaking about the psychological process that leads to the approval of an object and, therefore, to its recognition as a virtue. Instead, he is referring to the existing moral foundation for attributing it.

11. T.3.3.1.30.

12. T.3.3.1.24

13. T.3.3.2.13

14. T.3.3.4.3.

15. T.3.3.3.3. For a detailed study of the entire specific list of virtues, which are complex and perhaps even heterogeneous, in Hume, see O'Brien, 'Hume and the Virtues'.

16. Geoffrey Sayre-McCord (ed.), in David Hume: Moral Philosophy (Indianapolis: Hackett, 2006), xviii, argues that Hume has no link to utilitarianism. For him, actions are never the objects of our moral evaluation. In my view, this author, a point of reference for many anti-utilitarian scholars on Hume, makes the simple mistake of reading a text by Hume (T.3.3.1.4.) in a very partial way. Hume seems to deny that actions are subject to evaluation. In fact, he says they will be only insofar as they are linked to character. Thus, if an action that can be evaluated must come from a quality (virtue) or from character itself, it has to be an indication of a stable and lasting principle of the mind. These therefore can be extended to individual behaviour and can form that character precisely. Certainly, for that reason, if an action does not fulfil any of these requirements, it will not be taken into account in morality. Nevertheless, the interesting question is really the opposite: whether an action fulfils those requirements. Will the action count from the moral point of view? Nowhere does Hume say the contrary. This is also logical, since actions are the only external features of character, the sole way of making its evaluation accessible. How, if not from courageous acts, can we evaluate the value of someone, as well as the person's justice and benevolence? There is no other way than through the direct or indirect usefulness of these acts and corresponding character. These are examples, signs, external testing: the only ones that we have. The influential position of this author, contrary to the ties Hume has with utilitarianism, was originally formulated in Geoffrey Sayre-McCord, 'Hume and the Bauhaus Theory of Ethics', Midwest Studies in Philosophy (1996): for example, on page 280.

17. The natural virtues are those that: ' ... have no dependence on the artifice and contrivance of men' (T.3.3.1.1). Hume widely exemplifies what he means by natural virtues in T.3.3.3.4.

18. J. L. Mackie, Hume's Moral Theory, International Library of Philosophy (London: Routledge and Kegan Paul, 1980) 76-7.

19. I have done this before, especially in José L. Tasset, La ética y las pasiones: un estudio de la filosofía moral y política de David Hume (A Coruña: Universidade da Coruña, 1999), Chapter 6.

20. Based on the idea that virtue brings pleasure (and if it does not produce pleasure, it is not a virtue, although not all pleasure is associated with virtue, as is logical), Hume indicates that the natural virtues (e.g. an act of benevolent character) produce good from every particular individual or case, in every event connected with them (for example, all benevolent acts are virtuous and always produce good in a direct way). However, the artificial virtues (mainly justice) and the acts derived from them generate good as part of 'a general scheme or system of action' (T.3.3.1.12).

21. The appealing Humean discussion on the degree of stability-universality or modifiability (cultural-relativity) of these motives cannot be addressed here, despite being one of the most interesting aspects of Hume's approach in terms of contemporary ethics. See on this point, José L. Tasset, 'El relativismo ético: su naturaleza y sus problemas', Direito-USF (Universidade Sâo Francisco, Brasil), 17/2 (2000): 63-85.

22. See Mackie, Hume's Moral Theory, 81. Conversely, as we can deduct from Humean argument, there may be specific acts resulting from these artificial virtues that do not produce good directly. They may do so in an indirect, global or medium- to long-term way, in the context of the overall scheme. Hume develops this idea in a surprising and, in some sense, an unpredictable way at the end of the Enquiry through the so-called problem of the 'Sensible Knave'; see on this subject, José L. Tasset, 'De ladrones y reglas. (Una visión del problema del "Sensible Knave" desde un utilitarismo de la regla atemperado)', Daimon. Revista Internacional de Filosofía 52 (enero-abril 2011): 117-40.

23. Crisp, 'Hume on Virtue, Utility, and Morality', 159-60.

24. Merrill, Historical Dictionary of Hume's Philosophy, 271, suggests that this distinction loses strength and importance in EPM: ' ... he pretty much abandons the terminology of natural vs. artificial, but he continues to maintain that justice counts as a virtue only by reason of convention or artifice'. My view is that, in EPM, Hume clearly focuses on developing his theory of ar- 
tificial virtues, especially as it relates to justice. He does not abandon the distinction, on recognizing that utility of natural virtues is direct, not requiring much proof or analysis. In general, I feel that there is a decreased value or importance of the 'natural' and 'artificial' terms and not of the distinction between justice and the other virtues. The theory is maintained as a whole, but Hume avoids that purely terminological discussion. He overly focuses on the themes of 'artificiality' of justice and property, which had caused him so many problems. Thus, although the manner of developing this distinction between natural and artificial virtues changes from the Treatise to the Enquiry, that conceptual difference continued to be one of the most original points of Hume's moral and political theory. It is precisely the clue to the crucial link between utilitarianism and naturalism.

25. Bentham, A Comment on the Commentaries and A Fragment on Government, 439.

26. This sceptical interpretation, derived from Hume's reading made by the majority of his contemporaries, was first proposed as a standard by James Beattie and after by Hume's works published by Green \& Grose. It was assumed, I think without criticism, by Jeremy Bentham and later also by John Stuart Mill, and even by Bertrand Russell. It is only after the decisive work by Norman Kemp Smith - The Philosophy of David Hume: A Critical Study of Its Origins and Central Doctrines ([s.l.]: Macmillan, 1941) - was published that this radically sceptical interpretation of Hume's thought will begin to be revised in the twentieth century. My specific thesis is that a great part of the rejection that David Hume's ethics and political philosophy arouses among classical utilitarians stems from the presumption of scepticism that they uncritically attributed to Hume's thought. Even if this view is reconsidered and overcome, it obviously cannot be guaranteed that Hume's relationship with utilitarianism would be less difficult to understand. Nevertheless, it can be viewed in a more objective way.

27. This text leaves no room for doubt about Bentham's negative opinion of Humean epistemology and its implications; it is striking. However, in this judgement, Hume's entire theory of passions is also included and is far from being interpreted as simply sceptical. In fact, the Slave Passage, in which reason is subdued to the non-tyrannical government of passions, recalls in many respects the beginning of Bentham's Inquiry Concerning the Principles of Morals and Legislation. It describes the behaviour of human beings as being subjected to the domain of pleasure and pain, 'passions' in Hume's terms.

28. Bentham, A Comment on the Commentaries and A Fragment on Government, 439-40.

29. This last sentence is the ultimate clue to Bentham's dispute with Hume in regard to the concept of virtue and what makes him sceptical about the possible role of Humean ethical and political theory in how the utilitarian paradigm of rationality developed. I sincerely believe that Hume's resistance to converting utility into the sole explanatory element or the one-and-only cause of morality (and what it can entail, a complete primacy of action over motives or character, as well as an excessive focus on rationality over feelings) is one of the greatest successes of Hume's ethical theory. Utility and the consequent utilitarianism would explain to Hume a very important part of this moral experience, but they would not exhaust it.

30. Bentham, A Comment on the Commentaries and A Fragment on Government, 439-40.

31. Bentham's text, included in his Deontology, comes from the manuscript UC xiv, 297-301 and 303-5, June 1828; the first edition of this work was: Deontology: Or, the Science of Morality, two volumes, edited by John Bowring (London: Longman, Rees, Orme, Brown, Green \& Longman, 1834). A critical edition of this work is in Jeremy Bentham, Deontology; Together with A Table of the Springs of Action; and Article on Utilitarianism (Oxford: Clarendon Press, 1983). Hereafter I will quote this volume from Bentham's works in an abbreviated form as (CW [Collected Works], V [Volume V], plus the relevant page), for example, CW, V, 350.

32. The article by Bentham entitled 'Utilitarianism' was written for the editor of The Westminster Review in 1829 , but it was never published. There is a long version and a shorter one. Both are included in Bentham, CW, V.

33. The services of Hume, in much of the field of moral and mental philosophy, were immense. He first drew a clear distinction between impressions and ideas. Without this distinction, it is hardly possible to grasp many topics of great importance. The distinction is obvious when pointed out: '-I see a man-it is a perception: I close my eyes, but imagine myself to see him still—it is an idea.' Bentham, Deontology: Or, the Science of Morality (1834), 257 note. In the critical edition of Deontology, this note is much more extensive and even Bentham maintains that he does not understand how people could philosophize prior to this distinction: 'I do not know what people did before this distinction. It was a great discovery.' (CW, V, 350) Along with this, Jeremy Bentham cites this idea, the foundation of 'empiricist criterion of meaning' and its anti-metaphysical predominant use, as the basis of 'physical phraseology' (also CW, V, 
350), central to his theory of 'fictitious entities'. This is one of the great and profound influences of Hume's thought in Bentham. Its importance is such that it requires study apart from the issue of virtues, in order to be addressed in depth and precisely. This point is argued at the beginning of the work in regard to Hume's influence on Bentham.

34. This critique of Hume and others scattered throughout the vast work of Bentham have led Philip Schofield, in Bentham: A Guide for the Perplexed (London: Continuum, 2009), 3, for example, to consider how Bentham's opinion of Hume changed from his initial admiration in $A$ Fragment on Government. Schofield refers to this shift in a discussion contained in Bentham, Deontology; Together with A Table of the Springs of Action; and Article on Utilitarianism, 289-90, 322-84. Fred Rosen points out, rightly to my view, that if we read the famous Bentham text on Hume (see above) in its entirety, we find that Bentham was already very critical about Hume in that text and from that date on. However, this is not unusual in Bentham; he tended to introduce highly censorious comments about all of the authors whom he also praises. Apparently, it was not clear that his position on Hume changed so considerably over time.

35. CW, V, 322.

36. CW, V, 323.

37. CW, V, 323. It is later repeated, almost in the same words, in Deontology (CW, V, 357).

38. This is not a suitable place to analyse the different meanings of utility employed by Hume, Smith, Bentham and Mill. Nevertheless, Fred Rosen points out how the Humean use is compatible with classic utilitarianism. See Frederick Rosen, 'Reading Hume Backwards (Utility as the Foundation of Morals)', in Classical Utilitarianism from Hume to Mill (London; New York: Routledge, 2003), 29ff., in which the 'strong' thesis is not only (a) that utility is prime in Hume's thought, but (b) that it influenced how Bentham formulated the principle of utility.

39. This particular criticism seems especially unfair because the most original element of Hume's approach is the definition of virtue (see above), and not the resulting classification of virtues, on which Bentham concentrated.

40. In general terms, Bentham asserted that Hume's theory of virtues is incorrect because his theory of passions is also wrong.

41. CW, V, 323. In this respect, we may not fail to note that Bentham seems to focus on Book I of Treatise (which contains the theory of ideas that he so admires) and then on the third book (in which Hume is concerned with justice). However, the manner in which all concepts are linked with mental contents is found in Book II of Treatise, 'Of the Passions', later summarized in Dissertation on the Passions, which Bentham apparently overlooks; on the relevance of theory of passions for the correct understanding of Hume's moral and political philosophy, see Tasset, La ética y las pasiones, and Tasset, Disertación sobre las pasiones.

42. Bentham further notes that no normative consequence or even a purely practical one is derived from Hume's approach (recently, this has been brilliantly refuted in Rachel Cohon, 'Criticizing Hume's List of Virtues and Vices', in Hume's Morality (Oxford: Oxford University Press, 2008). Thus, according to Bentham, what Hume said, 'consists of mere speculation; no part of it has been applied by him, or is capable of being applied, in such sort as to be of use to practice' (CW, V, 324). This accusation of concealed conservatism runs parallel and is linked to the sceptical interpretation of Hume that was dominant at the time of Bentham and John Stuart Mill. It began to change only well into the twentieth century.

43. See UCL Benthamite Collection of Manuscripts, xiv, 300, 301 and 303-5 (written in June 1828), bearing the marginal title 'Hume's Virtues and J. Bentham's Intellectual Faculties'.

44. CW, V, 347.

45. CW, V, 347.

46. CW, V, 359.

47. CW, V, 347.

48. See note 36 .

49. The criticism concerning the Humean indefiniteness of virtue runs counter to the fact that, probably, the most original feature of Humean theory is the definition of virtue. In fact, it obviously does not coincide with Bentham's definition. In his explanation of the virtues, their potential natural dimension and their involuntary character or their possible relation to the intellect are completely excluded. All virtue seems to be, for Bentham, by exclusion, artificially and exclusively volitional.

50. See above, CW, V, 347. It is evident that a trait of the will can have a basis that is 'natural' and 'involuntary' as well as 'intelligent'.

51. See T.3.3.4.3-4. 
52. In fact, a significant number of the elements of character forming almost any virtue, or vice, are not completely voluntary. Any process of conception, deliberation and moral action has its basis, necessary but not sufficient, on certain cognitive-developmental structures (the 'qualities of the mind' by Hume). They are not entirely 'natural' because they are developed, but are rooted in a minimum endowment of natural character. If this is absent, it precludes both feeling and moral reasoning and, therefore, also parallel ethical conduct. Once again, the evolutionary and gradual perspective is decisive in understanding Humean views.

53. Crisp, 'Hume on Virtue, Utility, and Morality', 168.

54. Rosen,'Reading Hume Backwards', 49.

55. EPM.5.44.

56. Rosen, 'Reading Hume Backwards', 33.

\section{Bibliography}

Bentham, Jeremy. Deontology: Or, the Science of Morality, two volumes. Edited by John Bowring. London: Longman, Rees, Orme, Brown, Green \& Longman, 1834.

Bentham, Jeremy. Deontology; Together with A Table of the Springs of Action; and Article on Utilitarianism. Oxford: Clarendon Press, 1983.

Bentham, Jeremy. A Comment on the Commentaries and A Fragment on Government, The Collected Works of Jeremy Bentham. Edited by J. H. Burns and H. L. A. Hart. Oxford: Oxford University Press, 2008.

Cohon, Rachel. 'Criticizing Hume's List of Virtues and Vices'. In Hume's Morality. Oxford: Oxford University Press, 2008.

Crisp, Roger. 'Hume on Virtue, Utility, and Morality'. In Virtue Ethics, Old and New, edited by Stephen Mark Gardiner, 159-78. Ithaca, N.Y.: Cornell University Press, 2005.

Darwall, Stephen L. 'Hume and the Invention of Utilitarianism'. In Hume and Hume's Connexions, edited by M. A. Stewart and John P. Wright, 58-82. Edinburgh: Edinburgh University Press, 1994.

Hume, David. An Enquiry Concerning the Principles of Morals, a Critical Edition. In The Clarendon Edition of the Works of David Hume, edited by Tom L. Beauchamp. Oxford: Oxford University Press, 1998.

Hume, David. A Treatise of Human Nature. Edited by David Fate Norton and Mary J Norton, Oxford Philosophical Texts. Oxford: Oxford University Press, 2000.

Mackie, J. L. Hume's Moral Theory, International Library of Philosophy. London: Routledge and Kegan Paul, 1980.

Merrill, Kenneth R. Historical Dictionary of Hume's Philosophy. Historical Dictionaries of Religions, Philosophies, and Movements. Lanham, Md., [etc.]: Scarecrow Press, 2008.

O'Brien, Dan. 'Hume and the Virtues'. In The Continuum Companion to Hume, edited by Alan Bailey and Dan O'Brien, 288-302. London: Continuum, 2012.

Rosen, Frederick. 'Reading Hume Backwards (Utility as the Foundation of Morals)'. In Classical Utilitarianism from Hume to Mill, 29-57. London; New York: Routledge, 2003.

Sayre-McCord, Geoffrey (ed.). David Hume: Moral Philosophy. Indianapolis: Hackett, 2006.

Sayre-McCord, Geoffrey. 'Hume and the Bauhaus Theory of Ethics', Midwest Studies in Philosophy (1996): 280-98.

Schofield, Philip. Bentham: A Guide for the Perplexed. London: Continuum, 2009.

Smith, Norman Kemp. The Philosophy of David Hume: A Critical Study of Its Origins and Central Doctrines. [s.l.]: Macmillan, 1941.

Tasset, José L. David Hume: Disertación sobre las pasiones y otros ensayos morales (Dissertation on the Passions and Other Moral Essays), bilingual edn, 2nd edn. Barcelona: Anthropos, 2004.

Tasset, José L. 'De ladrones y reglas. (Una visión del problema del "Sensible Knave" desde un utilitarismo de la regla atemperado)', Daimon. Revista Internacional de Filosofía 52 (enero-abril 2011): 117-40.

Tasset, José L. 'El relativismo ético: su naturaleza y sus problemas', Direito-USF (Universidade Sâo Francisco, Brasil) 17/2 (2000): 63-85.

Tasset, José L. Hume: Obras. Madrid: Editorial Gredos, 2012.

Tasset, José L. La ética y las pasiones: un estudio de la filosofía moral y política de David Hume. A Coruña: Universidade da Coruña, 1999. 


\section{6 \\ Shaftesbury, Hutcheson and Mill on Pleasure and Virtue}

Roger Crisp

John Stuart Mill's hedonism - in particular, his arguments for a qualitative distinction between pleasures and for virtue as a constituent of happiness understood hedonistically - has been subjected to a huge amount of scrutiny, especially since the publication of the monumental Toronto edition of his works under the general editorship of John Robson. ${ }^{1}$ I have already contributed a few pebbles to this mountain of scholarly exegesis, and do not intend to add to it in this paper. Rather, I propose to focus on two British moral philosophers whose works in the eighteenth century could be described as broadly hedonist and who, like Mill, engaged closely with the questions of the relation of virtue and pleasure, and the roles of each in human happiness or well-being. Especially significant, perhaps, is the fact that both distinguished between higher and lower pleasures, placed virtue in the former category, and saw it as an important constituent of happiness. ${ }^{2}$

\section{Shaftesbury}

Anthony Ashley Cooper (1671-1713), 3rd Earl of Shaftesbury, was extremely influential on eighteenth-century thought, both philosophical and non-philosophical, in Britain and abroad. In philosophy, his impact on the sentimentalism of Hutcheson, Hume and others is often noted, though his own meta-ethics was a version of rationalist realism. That meta-ethics itself emerged from a broadly Platonic metaphysics, in which the potential for conflict between self and others was resolved through the postulation of a divinely created, ordered and governed universe, the 
mind of each individual being seen as part of a general mind or nature, divinely construed (e.g. 21 ; R 14-17, 138-9). ${ }^{3}$

Shaftesbury's early education was overseen by John Locke, who was a member of the 1st Earl's household. Shaftesbury remained deeply attached to Locke, but was critical of many of his views, including some of those in ethics and political theory. ${ }^{4}$ Shaftesbury saw the attempt to understand society and social morality as developing out of a pre-social state of nature as deeply mistaken, since human beings are naturally social (e.g. 51). Shaftesbury also disliked the voluntarist and divine command elements in Locke's thought and, in particular, the importance attributed to reward and punishment in the afterlife. In his earliest publication, a preface to an edition of sermons by the Cambridge Platonist Benjamin Whichcote, Shaftesbury allows that Christianity is the 'greatest Blessing imaginable', partly because of the excellence of its precepts and its enforcement of moral duties, and that without it morality would collapse entirely (P iii-iv). But he believed that virtue was a good in itself for the agent and that virtuous motivation did not need to, indeed could not, depend on goods or bads external to virtue, so that reference to divine punishment is required only when the non-instrumental arguments for virtue have failed (269; NL 11-12). Shaftesbury's theism is as rooted in ancient as in Christian thought, and his discomfort with the notion of a hell created by a benevolent and merciful God was clearly shared by Whichcote himself, who claims that, though God has indeed arranged matters so that vice leads to unhappiness, this punishment is inflicted internally and by the sinner himself, not by God (P xiii). ${ }^{5}$

Most of Shaftesbury's works were written in the five or six years leading up to their being published together in his Characteristics of Men, Manners, Opinions, Times in 1711. Shaftesbury revised the work over the two remaining years of his life, and a new edition was published in 1714 . This book, which went through eleven editions between 1711 and 1790, will be my main focus, ${ }^{6}$ but it is also important to consider other writings, in particular the highly personal and revealing Philosophical Regimen, a collection of Shaftesbury's personal notebooks, apparently written only for himself and not published until 1900.?

Let us turn to pleasure. Shaftesbury frequently appears staunchly opposed to evaluative hedonism. He criticizes the philosophical and theological orthodoxy of his day, according to which we should 'rate life by the number and exquisiteness of the pleasing sensations' and so 'learn virtue by usury', valuing it for the pleasure it can produce (and presumably the pain it can prevent) (57; also NL 19). Shaftesbury also finds problems internal to hedonism itself. First, pleasure cannot be the foundation 
of a 'rule of good', since those who aim at unrestricted pleasure are constantly changing their minds about what is and is not pleasurable (138; also 151-2, 252-3, R 50). Consistency can be found only through aiming at virtue: 'if honesty be my delight, I know no other consequence from indulging such a passion than that of growing better natured, and enjoying more and more the pleasures of society' (138-9; also R 54-5). Second, and relatedly, any evaluative claim must be universally true (R 56-7). To be happy requires contentment, and one can be content without unrestricted pleasure, just as one can without fame or power. Further, pain cannot be said to be evil, since some people can tolerate it.

These arguments, it has to be admitted, are somewhat weak. If aiming for unrestricted pleasure and avoidance of pain produces a lower balance of pleasure over pain than some other strategy, then an evaluative hedonist can recommend that alternative. Further, even though it is true that hedonic value can diminish marginally, there seems to be no reason why an evaluative hedonist should not take this into account in his/ her calculations, shifting to a new source at the optimum level to maximize the overall balance of pleasure over the pains of disappointment and boredom. Nor need the hedonist reject the universality claim. S/he can insist that the greatest balance of unrestricted pleasure over pain is universally good, and note that, since contentment is a kind of pleasure, Shaftesbury's own view can be understood as hedonist. ${ }^{8}$

As we might expect, given his Stoic views on desire, Shaftesbury puts a very high value on contentment or tranquillity: one moment of it is more valuable than a lifetime of the 'tumultuous joy' of friendship ( $R$ 116). It is stable, does not lead to disgust, and is immune to the vicissitudes of fortune (R 151-2, 208). It is 'nothing else than the good ordering of the mind', ${ }^{9}$ and Shaftesbury describes its absence, and indulgence in the passions, as 'near to real madness' (R 160).

Shaftesbury's main argument against unrestricted hedonism is again solidly Aristotelian. According to Aristotle, since all animals, including the intelligent ones, aim at pleasure, it would be absurd to claim that it is not a good. ${ }^{10}$ But not all pleasures are worthy of choice, so unrestricted hedonism is mistaken. ${ }^{11}$ The pleasure of virtuous actions is good, while that of vicious ones is bad, and the virtuous person is the touchstone of which pleasures are and are not valuable. ${ }^{12}$ And these are primarily the pleasures really characteristic of a human being - that is, the pleasures of virtuous action itself..$^{13}$ Shaftesbury is in broad agreement with Aristotle. Just as a man of 'breeding and politeness' will take care to develop his taste by focusing on the best architecture and paintings, so all of us should have 'the same regard to a right taste in life and 
manners' (150-1; also e.g. 335). Shaftesbury's objection, then, is not to hedonism, but to unrestricted hedonism (250-1).

This brings us to the question of how Shaftesbury views the value of virtue to the virtuous agent him/herself. In his earliest publication, Shaftesbury drew a distinction between a justification of virtue grounded on the intrinsic 'Pleasure and Contentment in Works of Goodness and Bounty' (which were also experienced by God) ${ }^{14}$ and one that appealed to 'some Advantage of a different Sort from what attends the Actions themselves' (P 10). Further, as one would expect, he accepts reasons of self-interest: 'we should all agree - that happiness was to be pursued and in fact was always sought after' (56; also 170).

Shaftesbury is most plausibly understood as a substantive hedonist about well-being, insofar as he believes that happiness consists in pleasurable experiences arising from valuable objects, and in particular the state of mental contentment arising from virtue and virtuous activity. ${ }^{15}$ Again, this position is close to that of Aristotle, though Aristotle is most plausibly read as claiming that happiness consists only in (pleasurable) excellent or virtuous activity, ${ }^{16}$ and, as we shall see, Shaftesbury reverses Aristotle's order of priority of intellectual activity over the exercise of the virtues of character. ${ }^{17}$ Shaftesbury is clearly not committed to explanatory hedonism, according to which the only good-making property is pleasantness. Pleasure in worthless objects is itself worthless. The fact that an experience is one of taking pleasure in a valuable object is itself good-making, but the explanatory account of goodness here is complex and must include reference to Shaftesbury's views on God, nature and perfection.

Shaftesbury's view on the content of morality is, in many respects, close to that of common sense. He is committed to many standard virtues, and appears to accept certain standard deontological views on justice, promising and other issues. There is a strong welfarist element in Shaftesbury's thinking - e.g. virtue aims at 'the general good' (230) and 'the good of mankind' (244) - but his frequent mention of values such as justice alongside the promotion of overall good (e.g. R 71-2) suggests that we should not interpret him as any kind of utilitarian. When he says that making the most of life consists in doing the most good (R 346), he has in mind avoiding selfishness and living virtuously. Nevertheless, Shaftesbury's insistence on impartiality and the promotion of the good of the whole does introduce a consequentialist element into his normative ethics. It seems that he believes, like many pure consequentialists, that following the partial principles of common-sense morality will in most cases promote the overall good, though he may well accept that there are 
non-consequentialist reasons for so doing (e.g. 255-6). So the practical implications of his impartiality principle are relevant only in those probably rare cases in which one is required to sacrifice the interests of those close to one for the sake of the overall good (see e.g. 205-7; R 6, 97). Further, there is no hint in Shaftesbury of the idea that one should adopt anything like Sidgwick's 'point of view of the universe', from which one's own good matters, as far as one's own practice is concerned, only as much as that of anyone else's. Some degree of partiality towards oneself is natural, and hence good and required. But there is no tension between the promotion of my good and the promotion of the overall good, since my good itself consists in the promotion of the overall good, as Shaftesbury conceives it. That is to say, the overall good does not consist in an overall sum of individual utilities, themselves calculated independently of that overall good. The overall good consists in the world's operating as it should, with each agent's following common-sense morality modified by the principle of impartiality.

Shaftesbury puts forward a series of suggestive and interrelated arguments to the conclusion that the life of the virtuous person is the happiest: ${ }^{18}$

(i) Natural affections. To lack 'honesty', that is, virtue, would be to lack the natural social affections, a life without which is wretched (56). When we consider some creature void of such affections, we suppose it will feel little pleasure and be inclined to moroseness and distress (194-5, 215-16, 431-2). The reason for its state, though we tend not fully to recognize it, is disharmony. If we 'strain' some affection, or act on some wrong passion, this will upset the balance of our mind, causing deep and lasting distress. Our dependence on society is greater than that of any other animal, and we all strongly desire to be in friendly relations with others. Suppressing that desire will lead to disharmony, discontent and unhappiness.

Shaftesbury's focus here, like that of Plato's in the Republic, is on the life of the entirely vicious person. Confronted by, say, some gangster, who appears to have genuine love and concern for his family and friends, Shaftesbury can only doubt that genuineness, or insist that such partial concern anyway puts the individual into a position of conflict with the good of the whole, which itself will result in discontent (the gangster's denial of that must again be taken to be disingenuous or the consequence of self-deceit) (194, 205-6; also Irwin, 360)..$^{19}$

(ii) Identity and character. In the Regimen, Shaftesbury appears to believe that continuity of correct moral opinion is required for identity over time. In the Characteristics, he makes the weaker claim that what a 
person is - i.e. we must assume, what kind of person he is - depends on the person's character and affections, so that if 'he loses what is manly and worthy in these, he is as much lost to himself as when he loses his memory and understanding' (56).

In both cases, Shaftesbury appears to be speaking of moral decline. It is not clear why someone whose opinions and character have been continuously villainous from the start should be denied the self of identity or of character required to ground any notion of self-interest.

(iii) Activity. It might be claimed that the highest pleasure is that of passive freedom from any kind of distress (142). But this life is equivalent to being asleep. True happiness consists in 'action and employment'.

In following Aristotle here, who also stressed the importance of activity as opposed to the mere possession of virtuous dispositions, ${ }^{20}$ Shaftesbury's position is plausible enough. But he fails to address the position of those who advocate a life of wakeful disengagement and, of course, those who press the claims of the life of vice tend to be recommending the life of vicious activity. Naturally, Shaftesbury will argue that luxury, like all vices, results in disharmony and hence discontent. But this is again an empirical claim, and it will be difficult for Shaftesbury plausibly to debunk apparent counterexamples. A more fruitful approach would be to accept the possibility of idle or vicious contentment but to question its value.

(iv) Perfectionism. Our own good or interest is itself the result of nature, and that good consists in fulfilling or perfecting our own nature $(167,205,428 ; R 257)$. As we have seen, Shaftesbury sees each individual as having a role to play in the promotion of cosmic order. Our playing that role itself constitutes our good; if we do not, our relation to the cosmos is like that of an unhealthy part of the body that grows unnaturally to the detriment of the body as a whole (R 49; 193). Our social affections are to promote not our own interest, but that of our species (R 3). However:

for a creature whose natural end is society, to operate as is by nature appointed him towards the good of such his society or whole is in reality to pursue his own natural and proper good. (432)

This order is clearly the result of design by a 'universal mind' (276), and this provides Shaftesbury with the material for a second perfectionist argument, independent of the claim that the good of an individual constituent consists in it fulfilling its natural role in promoting the good of the whole. For there to be a tension between the good of the part and 
the good of the whole, or between the self-interest of the individual and virtue, would itself be 'a blot and imperfection in the general constitution of things' (190).

Like most perfectionist arguments, Shaftesbury's can be accused of assuming what it is intended to prove. Shaftesbury himself accepts the naturalness of self-interest and the rationality of its pursuit, and so it is open to an egoist to argue that the perfection of any individual lies solely in promoting its own good. It is also possible to drive a wedge between the notions of perfection and well-being. ${ }^{21}$ An egoist may accept that my living virtuously and so promoting the overall good will perfect my human nature, but deny that this will advance my own good. Now this will, of course, introduce the kind of tension into the cosmos that Shaftesbury's second argument denies. But competition between individuals is fairly obviously part of the natural order, and the claim that the hierarchical order that results from competition is any less the result of divine intention than that which arises through cooperation is not well grounded.

(v) Higher pleasures. Shaftesbury claims that the pleasures (or perhaps rather 'enjoyments', 252) of virtue are superior to bodily pleasures. His discussion, in part II of the Inquiry in particular (200-30), is sophisticated and wide-ranging, and further subsections may be helpful.

(a) Mind versus body. Shaftesbury claims that most people will accept that the pleasures of the mind are greater than, and superior to, those of the body (200-2). As evidence, he cites the fact that those who have committed themselves to pursuing some mental pleasure cannot be diverted by bodily pleasures and pains. Even villains, on the basis of some principle of honour, will 'embrace any manner of hardship and defy torments and death'. In contrast, someone currently experiencing pleasures of the senses can easily be distracted by internal pain or distress.

These claims are, at the very least, somewhat hard to believe. But Shaftesbury also offers a dependency argument (211-12). Bodily pleasures depend on those of the mind - in particular, those of the natural affections. The pleasure of eating is insignificant without a table, company and so on; prostitutes know that their clients wish to believe that the pleasure the clients are feeling is mutual.

Besides again relying on dubious empirical premises, this argument brings out two further problems lying behind Shaftesbury's overall position. The first is an equivocation on the notion of 'social affections'. On the one hand, it can refer to the pleasures of virtuous activity; on the other, to the pleasures of company. It is at least arguable that vicious people can enjoy the company of others, even if they have no moral concern for those others and treat them purely as a source of entertainment. 
The second problem is with the very distinction between pleasures of the mind and those of the body. It could be that there is some important difference between, say, the pleasures of working through some elegant mathematical proof, and those resulting from a massage. Here we might have a real contrast between the intellectual and the sensual or physical. But the pleasure of refined eating may involve a good deal of reflective thought on the nature and origin of the foods in question; and the pleasures taken in the company of others are sometimes sexual and, to that extent, bodily.

(b) The Informed Preference Test. As Mill was later to do, ${ }^{22}$ Shaftesbury revives one of Plato's arguments for the superiority of mental over bodily pleasures in the Republic ${ }^{23}$ (202). To judge the relative value of two categories of pleasure adequately requires experience of each. The virtuous person understands sensual pleasure, while the vicious person cannot grasp social pleasure.

One worry here is again over whether there is empirical support for Shaftesbury's claim. Consider the objection as raised by Alan Ryan against Mill's argument in favour of mental over bodily pleasures: 'The philosopher who is a half-hearted sensualist cannot estimate the attractions of a debauched existence, any more than the sensualist flicking through the pages of Hume can estimate the pleasures of philosophy'. ${ }^{24}$ We might, however, allow Shaftesbury that at least some ordinarily virtuous people do seem capable of wholeheartedly enjoying sensual pleasures. A more serious problem is whether those virtuous people who, in certain circumstances, choose the pleasures of virtue over those of sensuality are doing so on the basis that the pleasures of virtue are more pleasant than those of the body. We might expect many of them to say that they prefer virtue, rather than the pleasures of virtue in particular, to bodily pleasure; that their own virtue would anyway decrease the amount of pleasure available to them from sensuality, if non-virtuous; and that their reasons for preferring virtue are moral rather than self-regarding. We can be sure that the judgements of some virtuous people would fit Shaftesbury's description; but there would be many that did not.

(c) Virtuous activity versus contemplation. Earlier in this paper, I noted various ways in which Aristotle's ethics appears to have influenced Shaftesbury, either directly or through the development of his ideas by Hellenistic philosophers. Notoriously, at the end of the Nicomachean Ethics, Aristotle ranks the intellectual activity of contemplation above that of practically virtuous activity. Here, Shaftesbury does not follow him (202-3). Shaftesbury is prepared to accept that intellectual pleasures are superior to those of sense. Those who apply their understanding 
of mathematical principles, for example, will experience an especially deep enjoyment resulting from 'love of truth, proportion, order and symmetry'. But even this pleasure is 'far surpassed by virtuous motion and the exercise of benignity and goodness ... For where is there on earth a fairer matter of speculation, a goodlier view or contemplation, than that of a beautiful, proportioned and becoming action?'.

Shaftesbury's ethical aestheticism again seems to involve reliance on empirically doubtful premises. Compare, for example, the pleasure Archimedes felt when he discovered the relation between volume and the displacement of water with that experienced by someone fulfilling a promise to a friend to post a letter for him/her on the way home.

(d) Consequences. Shaftesbury is prepared to identify the natural affections with mental enjoyments. But he also argues that certain mental enjoyments flow from those affections, in two ways (204-5). First, one is able sympathetically to experience a second-order, sympathetic enjoyment in the pleasure of others. Second, one can enjoy the admiration and esteem of others.

We have already seen the problems arising out of Shaftesbury's equivocation concerning the natural or social affections. A benevolent person will indeed take vicarious pleasure in the happiness of others, and may well enjoy his/her reputation. But the same will be true of at least some vicious people. The most that Shaftesbury can offer is an enticement to virtue for someone already attracted to it and the particular reputation that it will bring with it. It also has to be admitted that there is a tension between the argument from esteem and Shaftesbury's arguments elsewhere against attributing any great significance to reputation.

(e) Self-review. According to Shaftesbury, anyone who introspects will find that the pleasures he experiences alone or with others are 'wholly founded in an easy temper, free of harshness, bitterness or distaste, and in a mind or reason well composed, quiet, easy within itself and such as can freely bear its own inspection and review' (206, 208-10). By 'anyone' here, Shaftesbury must mean 'anyone virtuous', since he goes on to insist that the pleasures he has in mind are the result of the natural affections.

Some will wish to object that such self-review exemplifies a form of vanity or self-indulgence; but against this, it can plausibly be said that the absence of any kind of review is a sign of complacency. The problem is that many vicious people will also be able to bear or even enjoy this kind of self-review, in part because often the values against which they are assessing their own characters are themselves vicious (so while a virtuous person may be tormented by a single, uncharacteristically ruthless 
action, a vicious person may reflect on his/her ruthlessness with pride). Shaftesbury insists that all rational creatures will feel shame or regret at doing what is hateful (209). But unless he is building a capacity to feel such emotions into his account of rationality itself, Shaftesbury's confident generalization again seems open to doubt. Many psychopaths seem perfectly rational, in the procedural sense, and yet they feel little or no shame. It is true, of course, that wrongdoers are often tormented by guilt; one way to avoid that is to refrain from action one knows is likely to cause guilt. But another is to adopt strategies to weaken one's own proneness towards such negative emotions, as Nazis involved in the holocaust were encouraged to do.

(f) Excessive self-love and the unnatural affections. Shaftesbury analyses several self-regarding affections, including love of life (which can lead to a miserable fear of death, for example), anger, luxury, sexual desire, love of wealth, pride, and love of ease, along with certain 'unnatural' affections such as sadism (216-29). He argues plausibly enough that such affections, especially if excessive, can cause distress to their subject.

But the truth is significantly more complex than Shaftesbury allows, and depends on the existing nature and situation of the person in question. Some vicious people appear to enjoy excessive indulgence in luxury, pride or sadism, and even possibly intrinsically unpleasant emotions, such as anger, may have instrumental benefits for the vicious agent who can use them, for example, to extort goods from others.

The upshot of the above is we cannot accept that Shaftesbury has shown 'every vicious action must be self-injurious and ill', on the ground that such actions encourage and strengthen vicious traits. In some cases, virtue will be more advantageous than vice in hedonistic terms; but in others it will not (for example, in the case of the person morally required to allow him/herself to be tortured). Further, Shaftesbury will face objections to his account of well-being from two opposed directions. On the one hand, unrestricted hedonists will insist that the contentment on which Shaftesbury places so much weight is only one kind of enjoyment among others, all of which should be brought into the discussion; on the other, non-hedonists may insist that Shaftesbury should have gone further in the direction of the ancient view that virtue, or virtuous activity, matters independently of its hedonistic effects on the agent. Despite Aristotle's influence on him, and his rejection of various Lockean views, and of course his own inventiveness, Shaftesbury seems unable to shake off the egoism and hedonism that dominated British moral philosophy after Hobbes. 


\section{Hutcheson}

Francis Hutcheson (1694-1746) was born in Northern Ireland and educated at the University of Glasgow, where he took up the chair of Moral Philosophy in 1729. His work played a significant role in the Scottish Enlightenment, influencing Hume, Smith and Reid, as well as many thinkers beyond Scotland. ${ }^{25}$ Hutcheson himself was modest about his own originality (S 1.xlvii: 'All who have looked into such subjects know that the general doctrine and foundation of morals may be found in the antients ... [Plato, Aristotle, Xenophon, Cicero], and in Dr. Cumberland, and in Lord Shaftesbury' (SI 5). ${ }^{26}$ It is true that his views in general have a good deal in common with these predecessors, but also that the detailed and powerful statement of those views, including not only his theory of moral sense but also his position on morality and self-interest, is imaginative, historically significant, and highly suggestive. Given our focus on Hutcheson as a precursor to Mill, it is worth noting that Hutcheson sees more deeply than Cumberland into the true nature of broadly utilitarian impartiality, while usually avoiding Shaftesbury's equivocation between genuine impartiality and the pleasures of partial friendship. Further, although he is a devout Christian, and his ethics is theistic in certain important respects, unlike Shaftesbury he tends to maintain a clear distinction between religious and moral experience. Hutcheson is in this respect strongly committed to the idea of natural law, seeing the aim of moral philosophy as being to demonstrate to each person, with reference to nature rather than the supernatural, that their individual greatest happiness lies in virtue (I 179; E 174-5; S 1.1). ${ }^{27}$

Hutcheson was, for most intents and purposes, an evaluative hedonist, at least at the substantive level, and held also that pleasure is the sole object of the will (LM 126). ${ }^{28}$ The happiness of any individual is identical with 'pleasant perceptions', and public happiness is merely the aggregate of such perceptions (RL 42). These perceptions give us our first idea of natural goodness, and we attribute immediate goodness to those objects likely to produce such perceptions, such as drink or harmony, and mediate goodness to objects instrumental to immediate goodness, such as wealth (I 86). The same relations, of course, hold between pain and badness, and lead to aversion rather than positive desire (e.g. S 1.4; I 26). Hutcheson's definitions of happiness are less precise than those of his successors in the hedonist tradition. For example, he defines happiness as 'a state wherein there is plenty of such things as excite these general sensations or one kind or another, and we are free from pain', and misery as 'frequent and lasting sensations of the painful and disagreeable sorts, 
excluding all grateful sensations'. Further, like Mill, ${ }^{29}$ he did not sustain a clear distinction between happiness as pleasure, and happiness as the greatest balance of pleasure over pain within a life. But it is clear that he recognizes that pleasures and pains can be weighed against one another, and his advocacy of maximization at both the intra- and interpersonal levels suggests that he would have accepted a conception of well-being according to which it consists in the greatest balance of pleasure over pain. Degrees of pleasantness and painfulness depend entirely on their intensity and duration (e.g. E 37).

Often (e.g. E 9), Hutcheson appears to mean by 'intensity' degree of pleasurableness. At times he appears to distinguish between intensity and dignity. For example, the earlier statement of the seventh axiom of calm desire is: 'In computing the Quantities of Good or Evil, which we pursue or shun, either for our selves or others, when the Durations are equal, the Moment is as the Intenseness' (E 37). Hutcheson later added 'or Dignity of the Enjoyment' (E 210). Indeed, he allows that the dignity of certain individuals can justify choosing an outcome in which they benefit over another of equal hedonic value (E 39). At SI 9, he claims that we should compare enjoyments according to their dignity and duration, making no mention of intensity. And at SI 54, dignity appears to be equivalent to value at a time: the dignity of the sensual pleasures consists only in the 'intenseness of the pleasure in the sensation'; the superior pleasures have their own 'excellence'. Hutcheson does believe that dignity - understood as something like 'excellence' - can increase pleasurableness, because of the pleasure taken in dignity, claiming: 'These moral Pleasures do some way more nearly affect us than any other: They make us delight in our selves, and relish our very Nature. By these we perceive an internal Dignity and Worth; and seem to have a Pleasure like to that ascribed often to the Deity, by which we enjoy our own Perfection, and that of every other Being' (E 107; also S 1.132). But it is tempting to think that, like Mill, Hutcheson at least comes close to allowing that non-hedonic properties of experiences can increase a person's well-being directly, as well as indirectly through increasing pleasurableness. In other words, Hutcheson is a substantive but not an explanatory hedonist. The moral pleasures are best for us, but not merely because of their greater pleasurableness: their dignity also matters. Consider also S 1.117: 'By this intimate feeling of dignity, enjoyments and exercises of some kinds, tho' not of the highest degree of those kinds, are incomparably more excellent and beatifick than the most intense and lasting enjoyments of the lower kinds' (also I 4, 77; E 94-5; S 1.29, 117, 129, 2.380; SI 40, 56-7). ${ }^{30}$ And, of course, there is a corresponding indignity in vice, which makes it the 
greatest evil (S 1.139-40). Nevertheless, it would certainly be fair to say that the dominant idea emerging from Hutcheson's ethics is that the balance of pleasure over pain should be maximized at both individual and social levels, and that pleasantness and painfulness are the most significant good- and bad-making properties respectively.

As is standard in philosophical discussions of pleasures and pains, Hutcheson divides each into various different categories (SI 55-62, 70; also $S$ 1.116-39). The most basic are bodily or sensual pleasures, which are felt when we satisfy those appetites we share with non-human animals. They have 'none of that dignity which is the object of praise'. Next are those pleasures that emerge from the 'elegance and grandeur of life', as well as those of the arts, sciences and intellectual activity in general. These pleasures are 'purer ... more honourable and joyful', and yet not absolutely the highest. The next highest are those of sympathy, as we can see from the fact that we will not envy a person with profuse bodily and intellectual pleasures, but no social pleasures. Unlike Shaftesbury, Hutcheson distinguishes clearly between these pleasures and those of the conscience or moral sense, which arise through reflection on one's own character and actions. And it is in the pleasures of virtue - in particular, acting virtuously - that we find the 'highest happiness'. Hutcheson's detailed arguments for this broadly hedonistic view are perhaps the most developed in the history of philosophy, though as with Shaftesbury some of them depend on dubious empirical claims.

Hutcheson takes care to reject those versions of Stoicism according to which what is central is making oneself immune to contingent harms (E 83). That would involve a failure of compassion for the suffering of others, an excessive focus on the self rather than others, and a move towards passive retreat from the world rather than active engagement with it (also $S$ 1.132). Such a position is in effect inconsistent with true human nature, which reveals itself when the agent is calm - and hence impartially benevolent (I 164). Our benevolent nature is of course the result of benevolent design (RL 53; E 8; S 1.1.75; SI 23, 40), and so we should not be surprised to find that our moral sense is itself designed to give its possessors pleasure (I 100). ${ }^{31}$ Hutcheson also locates himself within the perfectionist Aristotelian tradition, according to which happiness itself consists in the perfection of one's nature (S 1.29). This general position resonates with his revival of the Shaftesburian argument that, since the self is independent of the body, the bodily pleasures are in that sense alien and inferior (E 107; $S$ 1.147).

As we have seen, pleasures are of different kinds. How should we compare them? Referring appropriately to Plato and Shaftesbury, and 
anticipating Mill, ${ }^{32}$ Hutcheson advocates reliance on the verdicts of a competent judge, rather than on each individual's position (rather than a pig, Hutcheson imagines a fly or maggot judging its pleasures to be superior to all others) (E 88-9; also S 1.120-1; SI 57). According to such a judge, there is no doubt that the pleasures of virtue are the highest. These include the pleasures of benevolence (I 134; S 1.140-1, 147), but also those of piety, which Hutcheson tends to classify independently and as the very highest (S 1.222, 234; SI 87).

As far as benevolence is concerned, pleasantness increases with impartiality (S 1.132). As we might expect, this pleasantness is at least to some extent aesthetic: 'in some extensive Principles of Action', as in certain theorems, we perceive a beauty analogous to that in sensible objects (I 24). ${ }^{33}$ The approving awareness of one's own virtue is a great joy (SI 40-1), while vice brings with it the pains of guilt, regret and remorse (SI 40, 66, 145, 147), and of reproach by others (SI 148). These pains are themselves distracting, making it impossible for the subject to focus on the sources of external, or bodily, pleasure (SI 63). Remorse also often arises after indulgence in the bodily or sensual pleasures (SI 56, 126), whereas reflection on past virtuous deeds is deeply pleasurable (RL 45; SI 61) and the development of a virtuous habit increases pleasure even further (S 1.133). Even in the absence of such remorse, reflection on past external pleasures is hedonically neutral, and such pleasures are brief and transient, producing nauseous satiety and languor (I 164; E 105-8; S 1.124, 132, SI 56, 88-9). Just as the pleasures of virtue have the greatest duration, the same is true of those of vice (E 108; SI 66): unlike Mill, Hutcheson allows for different qualities of pain as well as pleasure (SI 100, 139).

The pleasures of virtue, unlike even those of the imagination, are a support in difficult times (E 105-6), and the virtuous can even rise above physical pain (RL 46; S 1.151-2). Further, if pain is an obstacle to a virtuous action, that of course only increases its value (I 165). The virtuous can enjoy the external pleasures, and do not need them in excess: a simple life is sufficient (I 1.106; S 1.127). In general, 'external' goods such as wealth are required for 'complete' happiness (SI 64, 222), but the virtuous gain more from them (E 104). Their moderation increases pleasures from such sources (SI 58), while unmoderated indulgence itself causes vexation. Further the virtuous, because others will feel affection for them, are more likely to be beneficiaries as well as benefactors.

The emotions of the vicious - anger, malice, and so on - make them miserable even when opportunities for external pleasure are open to them (I 164). In response to the objection that the vicious clearly do experience some valuable external pleasures, Hutcheson can respond 
that this is true only of the majority of the vicious who are in a way partly virtuous (S 1.153, 191-2). Virtue consists in benevolent affections, and most of the vicious have some social affections, which are valuable in themselves and may make it possible for the vicious to gain some value also from external pleasures (SI 57).

These points are part of the explanation of why virtue is necessary for other goods to be valuable (I 165-7; S 1.126). But there is another component to this explanation. Consider the Roman Regulus who, set free by the Carthaginians on condition that he would return, did so only to be tortured. We might wish that he had not been tortured; but none of us would wish, for his sake, that he had broken his promise. This is a very clear example of the work being done by dignity in Hutcheson's account. Only pleasures are valuable, but their value depends not only on their being pleasant, but on their dignity. In this respect, then, Hutcheson, as Mill was tempted to do, moves away from a pure explanatory hedonism to allow in non-hedonic good-making properties. Many have wondered why Mill did not go the whole way, and move beyond substantive hedonism altogether, perhaps even allowing happiness to consist in more than subjective states - in particular, in virtuous actions. The same question arises for Hutcheson, as does the question of whether the approval we feel for Regulus's behaviour may be grounded in our view of the morality of his actions rather than whether he himself benefited from them.

We can now grasp the main outlines of Hutcheson's conception of the role of virtue in happiness. In general, his view is that the pleasures of impartial benevolence, combined with piety, are discontinuously more valuable than others, and for that reason virtue guarantees the best outcome for the agent, usually in terms of positive happiness but sometimes only in the diminution of misery (S 1.178; SI 78, 249). In certain passages, however, Hutcheson appears to accept weaker views. He allows that death may be preferable for a person 'under grievous bodily pain' (SI 65), implying that the exercise of courage in such circumstances is insufficient for happiness. At E 97-8, his argument for the superiority of virtue over the avoidance of bodily pain explicitly appeals to actions of great virtue, when his stated position elsewhere appears to be that all virtuous pleasure is superior to the avoidance of bodily pain of any kind. At E 143, he claims that the reasonable person will examine the tendencies of the various types of action s/he considers doing, and that the pursuit of the public good is the most probable route to the greatest happiness. These and other passages, though in a minority, suggest a certain - quite justifiable - reluctance on Hutcheson's part to accept the strong Stoic thesis that virtue guarantees the greatest happiness and hence immunity to 
fortune. That reluctance may be explained partly by his commitment to substantive hedonism. It may be somewhat implausible to claim that the virtuous person who chooses to die in agony on the rack has lived the happiest or even the best life possible for him/her; but to claim that $\mathrm{s} /$ he has experienced the most pleasurable life is even harder to believe.

\section{Shaftesbury, Hutcheson and Mill}

There is no doubt that John Stuart Mill was familiar with the works of both Shaftesbury and Hutcheson. Although he does not explicitly mention either as direct influences, it is instructive to consider the parallels between their work and his, and to reflect upon the standard questions, and range of answers, constituting the philosophical background against which all three philosophers were working. All were substantive hedonists about well-being, believing human happiness to consist only in pleasures. Shaftesbury is not an explanatory hedonist, but the role Hutcheson placed on dignity, and Mill on nobility in his own account of higher pleasures, is evidence that at the very least they were tempted by an Aristotelian, non-hedonist position. Shaftesbury's view is not a form of utilitarianism, but it is theoretically and practically close to it. All three philosophers distinguish between higher and lower pleasures, using, among others, the Socratic appeal to the experienced judge. All see virtue as a central component in happiness, though here we do see a contrast between Mill and his two predecessors. Mill's attempt to close the apparent gap between self-interest consists in the very brief second stage of his famous proof in the fourth chapter of Utilitarianism, along with a somewhat vague and optimistic appeal to the potential of moral education in the third chapter. Unlike Shaftesbury and Hutcheson, Mill had to work hard to defend hedonism, and the opposition to utilitarianism was in Mill's day a good deal more developed than that faced by Hutcheson. Given the weakness of any hedonist defence of a complete overlap between happiness and virtue, which he may well have noted in Shaftesbury and Hutcheson, Mill may have decided to focus on battles he had a better chance of winning. ${ }^{34}$

\section{Notes}

1. This paper uses material from chapters 7 and 9 of my book Sacrifice Regained: Morality and Self-Interest in British Moral Philosophy from Hobbes to Bentham (Oxford: Clarendon Press, 2019). I am grateful to Oxford University Press for permission. 
2. The J. S. Mill library at Somerville College, Oxford, contains the 4th edition of Shaftesbury's Characteristicks of Men, Manners, Opinions, Times (1727) and a 1st edition of Hutcheson's System of Moral Philosophy (1755). Both contain annotations in Mill's hand, along with textual side-markings. Some of these concern happiness and virtue. For example, at the very end of the second volume of the System, Mill includes the following notes (Mill, 2018): '25 Approbation from others, excites pleasurable feelings; disapprobation painful. Again; why stop short? These feelings, not the idea of the good the man who approves may do us. True; but they are the train of pleasurable ideas (a much richer collection) of all the advantages which the favour of mankind yields to them who obtain it'; ' 42 Acts good for others done by us for the good they will do to us, not virtuous. True, in the sense you now use the phrase, "good to us". But an act done by us, to produce a good to others which calls up all the train of pleasurable ideas which spring from the idea of good acts done mutually by men to one another is virtuous'; ' 100 The value of pains + pleasures measured, by intensity + durability'.

3. All unattributed page references are to Shaftesbury, Characteristics of Men, Manners, Opinions, Times, ed. L. Klein (Cambridge: Cambridge University Press, 1999). Other Shaftesbury abbreviations used in the text are as follows: 'Preface' to Select Sermons of Dr Whichcot [P]; Several Letters Written by a Noble Lord to a Young Man at the University [NL]; The Life, Unpublished Letters, and Philosophical Regimen of Anthony, Earl of Shaftesbury [R]; Second Characters or the Language of Forms [SC].

4. At SC 178, for example, Locke and Hobbes are classed together - apparently as 'barbarians' for their denial of ethical aestheticism.

5. Shaftesbury describes such punishment as 'inherent', which it insofar as the painfulness is a property of the vicious action itself. But it is not clear (pace M. Gill, The British Moralists on Human Nature and the Birth of Secular Ethics [Cambridge: Cambridge University Press, 2006], 79) that this conception of inherent punishment (and reward) entitles Whichcote or Shaftesbury to the claim that we should care about virtue for its own sake, rather than for its inherent benefits.

6. The Inquiry, included in the Characteristics, has usually been seen as Shaftesbury's most significant contribution to philosophical ethics. As noted by I. Rivers, Reason, Grace, and Sentiment: A Study of the Language of Religion and Ethics in England, 1660-1780, vol. 2: Shaftesbury to Hume (Cambridge: Cambridge University Press, 2000), 108, also 111, it is unwise to read the Inquiry independently of The Moralists (note especially her quotation from Leibniz at 108n108).

7. That edition itself is problematic: see R. Voitle, The Third Earl of Shaftesbury, 1671-1713 (Baton Rouge: Louisiana State University Press, 1984), 354. An annotated version of the manuscripts is now available in Shaftesbury, Standard Edition II, 6: Askêmata, eds. W. Benda et al. (Stuttgart and Bad Cannstatt: Frommann-Holzboog, 2011). Many themes are common between the Characteristics and the Regimen. The overlap is most noticeable in the Soliloquy and The Moralists, both of which are printed in the Characteristics (see J. Sellars, 'Shaftesbury, Stoicism, and Philosophy as a Way of Life', Sophia, 2015, 7-8. DOI: 10.1007/s11841-015-0483-z).

8. H. Sidgwick, Outlines of the History of Ethics, 5th edn (London: Macmillan, 1902), 185n1.

9. Marcus Aurelius, Meditations, Books 1-6, tr. C. Gill (Oxford: Oxford University Press, 2013), 20.

10. Aristotle, Nicomachean Ethics, trans. R. Crisp, 2nd edn (Cambridge: Cambridge University Press, 2014), 1172b35-1173a1.

11. Aristotle, Nicomachean Ethics, 1174a8-11.

12. Aristotle, Nicomachean Ethics, 1176a15-16.

13. Aristotle, Nicomachean Ethics, 1176a22-9; see 1198a16-17.

14. Shaftesbury's point here is reminiscent of Aristotle's suggestion that we ought to 'take on immortality as much as possible, and do all that we can to live in accordance with the highest element within us' (Aristotle, Nicomachean Ethics, 1177b33-4).

15. Shaftesbury's aim in Pt. 2 of the Inquiry is to show that having the natural affections is to have 'the chief means and power of self-enjoyment', and that having excessive private affections, or having unnatural affections, leads to misery; he notes that happiness is 'generally computed' from 'pleasures or satisfactions' (200-1, 216). T. Irwin, The Development of Ethics, vol. 2: From Suarez to Rousseau (Oxford: Clarendon Press, 2008), 358 - see S. Grean, Shaftesbury's Philosophy of Religion and Ethics: A Study in Enthusiasm (Athens, Ohio: Ohio University Press, 1967), 229-32 - referring to 250-1, claims that, according to Shaftesbury, the pleasant is merely what we think eligible. But Shaftesbury can be understood here to be objecting to a particular 
version of unrestricted hedonism. Seeing will and pleasure as 'synonymous' is equivalent to calling everything that pleases us 'pleasure'.

16. R. Crisp, 'Aristotle's Inclusivism', Oxford Studies in Ancient Philosophy 12 (2004): 111-36.

17. Aristotle, Nicomachean Ethics, 10.7-8.

18. Gill, The British Moralists, Ch. 9, finds in Shaftesbury a separate teleological argument for virtue, independent of the 'mental enjoyment' account, and argues for tensions between the two. I read Shaftesbury's teleology as supporting the mental enjoyment account (if anything, Gill sees the relation running the other way: see Shaftesbury, Standard Edition, sect. 4, penult. para.; also E. Albee, 'The Relation of Shaftesbury and Hutcheson to Utilitarianism', Philosophical Review 5 (1896): 29). In outlining the teleological argument, Gill (120) quotes the question Shaftesbury suggests asking one of the 'sportly gentlemen' about a bitch who eats her puppies: 'whether he thinks the unnatural creature who acts thus, or the natural one who does otherwise, is best in its kind and enjoys itself the most' (430) [my italics].

19. Irwin, The Development of Ethics, 360.

20. Aristotle, Nicomachean Ethics, 1095b30-1096a2; 1098b18-20.

21. P. Glassen, 'A Fallacy in Aristotle's Argument about the Good', Philosophical Quarterly 7 (1957): 319-22.

22. J. S. Mill, Utilitarianism, ed. R. Crisp (Oxford: Oxford University Press, 1998), 2.5.

23. Plato, Respublica, ed. S. R. Slings (Oxford: Oxford University Press, 2003), 581e-583a.

24. A. Ryan, J. S. Mill (London: Routledge and Kegan Paul, 1974), 111.

25. See, for example, T. Campbell, 'Francis Hutcheson: "Father" of the Scottish Enlightenment', in The Origins and Nature of the Scottish Enlightenment, eds. R. Campbell and A. Skinner (Edinburgh: John Donald, 1982), 167-8.

26. Hutcheson abbreviations used in the text are as follows: Reflections upon Laughter and Remarks upon the Fable of the Bees [RL]; A System of Moral Philosophy [S]; An Essay on the Nature and Conduct of the Passions and Affections, with Illustrations on the Moral Sense [E]; Logic, Metaphysics, and the Natural Sociability of Mankind [LM]; Philosophiae Moralis Institutio Compendiaria, with A Short Introduction to Moral Philosophy [SI]; and An Inquiry into the Original of Our Ideas of Beauty and Virtue [I].

27. Hutcheson's central ethical texts fall into three broad groups. The fundamentals of his ethics were stated in the four influential treatises in I and E. Twenty or so years later, the Institutio appeared, to be translated into English as SI in 1747. In the meantime, Hutcheson had been working on S, which was published posthumously by his son. His views did change, but in general on the nature of morality and self-interest they remained largely consistent (see L. Stephen, History of English Thought in the Eighteenth Century, 2 vols (London: Smith, Elder, 1876), 2.57). For helpful discussions of the development, or lack of it, in Hutcheson's views, see W. R. Scott, Francis Hutcheson: His Life, Teaching and Position in the History of Philosophy (Cambridge: Cambridge University Press, 1900), Chs 9, 10, 11 (1), 12; J. Moore, 'The Two Systems of Francis Hutcheson: On the Origins of the Scottish Enlightenment', in Studies in the Philosophy of the Scottish Enlightenment, ed. M. A. Stewart (Oxford: Clarendon Press, 1990), 37-59; S. Darwall, The British Moralists and the Internal 'Ought' (Cambridge: Cambridge University Press, 1995), Ch. 8; J. Bishop, 'Moral Motivation and the Development of Francis Hutcheson's Philosophy', Journal of the History of Ideas 57 (1996): 277-95. Note that the Liberty Fund prints, in a revised edition, the second edition of I, but with complete textual notes of variations in the other three significant editions.

28. In his later writings (e.g. SI 48), Hutcheson spoke of the love of virtue itself, which may be taken as a source of non-hedonic motivation independent of both self-interest and morality: see Bishop, 'Moral Motivation', 289-91.

29. Mill, Utilitarianism, 2.2.

30. For an interpretation of Hutcheson as a purely 'quantitative' hedonist, see D. Dorsey, 'Hutcheson's Deceptive Hedonism', Journal of the History of Philosophy 48 (2010): 445-67. By quantitative hedonism, Dorsey means the view that the welfare value of a pleasure is simply a function of its pleasurableness (446). He later cites the link made by Hutcheson at S 100 between 'supreme happiness' and 'the most intense and durable pleasures' as evidence for a quantitative interpretation (Dorsey, in fact, says 'qualititative', but he has confirmed to me that this is a typographical error). But if by 'intensity' Hutcheson means degree of pleasurableness-at-a-time, the passage seems consistent with forms of qualitative hedonism according to which pleasurableness depends partly on dignity and/or welfare consists in the greatest pleasures, the welfare value of which depends at least partly on dignity as well as pleasura- 
bleness. M. Strasser, 'Hutcheson on the Higher and Lower Pleasures', Journal of the History of Philosophy 25 (1987): 521-2, suggests that Hutcheson is not open to Moore's objection to Mill that allowing quality as well as quantity of pleasure to count commits Mill to a non-hedonist position, because 'Hutcheson does not believe in the intrinsic moral worth of happiness or pleasure'. But, as Strasser himself notes, Hutcheson does believe in the intrinsic natural value of pleasure, and Moore's argument - for what is it is worth - could be directed against that position.

31. This teleological element in Hutcheson's thought is a problem for any account of the role of the moral sense in the origin of our moral distinctions that rules out teleology (e.g. Gill, The British Moralists, 177-8).

32. Mill, Utilitarianism, 2.5-8.

33. Hutcheson almost certainly has impartial benevolence in mind here; see e.g. the reference to 'extensive affections' at S 1.59-60. In a later edition, Hutcheson stated that the purpose of geometry is to show how what is true of one figure is also true of others; from the practical perspective, he may have in mind the extension of the scope of practical principles from egoism, through partial benevolence, to impartial benevolence.

34. This essay is dedicated to Fred Rosen, in admiration of his scholarship and in gratitude for his guidance, support and friendship over many years. I wish also to thank the editors for their invitation to present an earlier version at a symposium in honour of Fred, held at the Royal Historical Society in October 2017, and the audience for discussion and comments.

\section{Bibliography}

Albee, E. 'The Relation of Shaftesbury and Hutcheson to Utilitarianism', Philosophical Review 5 (1896): 24-35.

Aristotle, Nicomachean Ethics. Translated by R. Crisp, 2nd edn. Cambridge: Cambridge University Press, 2014.

Bishop, J. 'Moral Motivation and the Development of Francis Hutcheson's Philosophy', Journal of the History of Ideas 57 (1996): 277-95.

Campbell, T. 'Francis Hutcheson: "Father" of the Scottish Enlightenment'. In The Origins and Nature of the Scottish Enlightenment, edited by R. Campbell and A. Skinner, 167-85. Edinburgh: John Donald, 1982.

Crisp, R. 'Aristotle's Inclusivism', Oxford Studies in Ancient Philosophy 12 (2004): 111-36.

Crisp, R. Sacrifice Regained: Morality and Self-Interest in British Moral Philosophy from Hobbes to Bentham. Oxford: Clarendon Press, 2019.

Darwall, S. The British Moralists and the Internal 'Ought'. Cambridge: Cambridge University Press, 1995.

Dorsey, D. 'Hutcheson's Deceptive Hedonism', Journal of the History of Philosophy 48 (2010): 445-67.

Gill, M. The British Moralists on Human Nature and the Birth of Secular Ethics. Cambridge: Cambridge University Press, 2006.

Glassen, P. 'A Fallacy in Aristotle's Argument about the Good', Philosophical Quarterly 7 (1957): 319-22.

Grean, S. Shaftesbury's Philosophy of Religion and Ethics: A Study in Enthusiasm. Athens, Ohio: Ohio University Press, 1967.

Hutcheson, F. [1725]. An Essay on the Nature and Conduct of the Passions and Affections, with Illustrations on the Moral Sense [E]. Edited by A. Garrett. Indianapolis: Liberty Fund, 2002.

Hutcheson, F. [1725]. An Inquiry into the Original of Our Ideas of Beauty and Virtue [I], rev. edn. Edited by W. Leidhold. Indianapolis: Liberty Fund, 2008.

Hutcheson, F. [1756/1749/1730, Latin]. Logic, Metaphysics, and the Natural Sociability of Mankind [LM]. Edited by J. Moore and M. Silverthorne, translated by M. Silverthorne. Indianapolis: Liberty Fund, 2006.

Hutcheson, F. [1745, Latin]. Philosophiae Moralis Institutio Compendiaria, with A Short Introduction to Moral Philosophy [English tr., 1747] [SI]. Edited by L. Turco. Indianapolis: Liberty Fund, 2007. 
Hutcheson, F. Reflections upon Laughter and Remarks upon the Fable of the Bees [RL]. Glasgow: R. Urie, 1750.

Hutcheson, F. A System of Moral Philosophy [S], 2 vols. Edited by F. Hutcheson. Glasgow: R. and A. Foulis, 1755.

Irwin, T. The Development of Ethics, vol. 2: From Suarez to Rousseau. Oxford: Clarendon Press, 2008. Marcus Aurelius. Meditations, Books 1-6. Translated by C. Gill. Oxford: Oxford University Press, 2013.

Mill, J. S. Utilitarianism. Edited by R. Crisp. Oxford: Oxford University Press, 1998.

Mill, J. S. 'Verbal Marginalia in Francis Hutcheson's A System of Moral Philosophy'. Edited by A. D. Pionke and E. A. Wilson. 25 September 2018. http://millmarginalia.org (accessed 19 March 2019).

Moore, J. 'The Two Systems of Francis Hutcheson: On the Origins of the Scottish Enlightenment'. In Studies in the Philosophy of the Scottish Enlightenment, edited by M. A. Stewart, 37-59. Oxford: Clarendon Press, 1990.

Plato. Respublica. Edited by S. R. Slings. Oxford: Oxford University Press, 2003.

Rivers, I. Reason, Grace, and Sentiment: A Study of the Language of Religion and Ethics in England, 1660-1780, vol. 2: Shaftesbury to Hume. Cambridge: Cambridge University Press, 2000.

Ryan, A. J. S. Mill. London: Routledge and Kegan Paul, 1974.

Scott, W. R. Francis Hutcheson: His Life, Teaching and Position in the History of Philosophy. Cambridge: Cambridge University Press, 1900.

Sellars, J. 'Shaftesbury, Stoicism, and Philosophy as a Way of Life', Sophia, 2015. DOI: 0.1007/ s11841-015-0483-z (online first).

Shaftesbury, 3rd Earl of. [1711]. Characteristics of Men, Manners, Opinions, Times. Edited by L. Klein. Cambridge: Cambridge University Press, 1999.

Shaftesbury, 3rd Earl of. 'Preface' to B. Whichcote, Select Sermons of Dr Whichcot [P], 1.[i-xviii]. London: Awnsham and John Churchill, 1698.

Shaftesbury, 3rd Earl of. Second Characters or the Language of Forms [SC]. Edited by B. Rand. Cambridge: Cambridge University Press, 1914.

Shaftesbury, 3rd Earl of. Several Letters Written by a Noble Lord to a Young Man at the University [NL]. London: J. Roberts, 1716.

Shaftesbury, 3rd Earl of. Standard Edition II, 6: Askêmata. Edited by W. Benda, C. Jackson-Holzberg, P. Müller and F. Uehlein. Stuttgart and Bad Cannstatt: Frommann-Holzboog, 2011.

Shaftesbury, 3rd Earl of. The Life, Unpublished Letters, and Philosophical Regimen of Anthony, Earl of Shaftesbury [R]. Edited by B. Rand. London: Swan Sonnenschein, 1900.

Sidgwick, H. Outlines of the History of Ethics, 5th edn. London: Macmillan, 1902.

Stephen, L. History of English Thought in the Eighteenth Century, 2 vols. London: Smith, Elder, 1876.

Strasser, M. 'Hutcheson on the Higher and Lower Pleasures', Journal of the History of Philosophy 25 (1987): 517-31.

Voitle, R. The Third Earl of Shaftesbury, 1671-1713. Baton Rouge: Louisiana State University Press, 1984. 
7

\section{'The First Article to Look to is Power': Bentham, Happiness and the Capability Approach}

Michael Quinn

Since its inception by Amartya Sen, the capability approach has become a major perspective from which to discuss well-being, development and social justice, and thus an attractive alternative utilitarianism. Sen famously rejects utilitarianism, and devotes few words, mostly negative, to Jeremy Bentham. ${ }^{1}$ Several attempts have been made to rescue John Stuart Mill from Sen's indictment, ${ }^{2}$ but little rehabilitative attention has been paid to Bentham. This discussion will argue first that Bentham anticipated some of the insights of the capability approach, and that both his discussions of the necessary and sufficient conditions for voluntary action, and his proposal that public policy address 'circumstances influencing sensibility', reveal a sensitivity to the determinants of 'effective liberty' of which proponents of the capability approach might approve. For reasons of space, neither a detailed exposition nor a critique of the capability approach is attempted, beyond a thumbnail sketch of Sen's initial presentation of functions and capabilities, and of his increasing focus on liberty. The paper attempts to respond to two criticisms levelled by Sen and Martha Nussbaum. First, that utilitarianism's exclusive focus on consequences in terms of utility overlooks the value of agency, and thereby overlooks both systematic violations of basic liberties and the demands of equality. ${ }^{3}$ Second, that evaluation exclusively in terms of subjective reports of affective mental states overlooks the phenomenon of 'adaptation', that is the reining-in of aspirations to avoid unhappiness, in background circumstances that themselves appear unjust. ${ }^{4}$ 


\section{Bentham and Sen on happiness and well-being}

Bentham never deviated from the view that the end of human life was happiness, ${ }^{5}$ and that happiness consisted in a net balance of pleasures over pains. ${ }^{6}$ The positive elements of experience were pleasures, the negative elements pains:

In vain, indeed, would the appellation matter of happiness be denied to the word pleasure, for in the pursuit of pleasure, accompanied all along with the avoidance of pain, will not man alone, but every sensitive being whatsoever, be at all times ... occupied.... Such is the fact ... : nor can any intelligible reason be assigned for so much as a wish that it were otherwise. ${ }^{7}$

Happiness or well-being - Bentham usually treats the expressions as synonymous $^{8}$ - was a property of the aggregate of sensations experienced by human beings, which sensations were the crucial variable in moral and political evaluation:

The feelings of individuals, sole elements of public happiness, these, and these only, are the considerations that have here been exclusively consulted, and their suggestions undeviatingly adhered to; human feelings, the only true standards of right and wrong in the business of legislation, not lawyers' quibbles, nor reasons of other times, that have vanished with the times. ${ }^{9}$

Bentham thus equates well-being with happiness, and proposes an entirely hedonistic view of the elements of happiness: 'Happiness is a vain word - a word void of meaning - to him to whose mind it does not explain itself by its reference to human feelings - feelings painful and pleasurable - pains and pleasures. ${ }^{10}$ A happy human being experiences more valuable agreeable sensations (pleasures) than disagreeable ones (pains), so that the value of the sum of the person's pleasures is greater than that of the sum of his/her pains. If the reverse is true, the person's condition is one of unhappiness, or ill-being. ${ }^{11}$ Current sensations vary in degree (intensity) and duration, their value being the product of the two variables (allowance made for fecundity and purity, or their tendency to foster further pleasures or pains); while in evaluating future sensations, a rational agent discounts their value according to their uncertainty and temporal distance. Insofar as the agent is a utilitarian (and Bentham's default perspective is that of the utilitarian legislator), s/he repeats the 
calculation for all sentient beings affected by an action, which Bentham calls the dimension of extent. ${ }^{12}$ Rational decision-making - including moral or legal decision-making - depended upon calculation, on the determination of quantities:

According to the principle of utility, taking in its entirety the whole mass of pleasure in question - presence or, in case of absence, propinquity and certainty, i.e. probability, being given or out of the question - quantity is the sole measure of value: ${ }^{13}$

For Sen, this approach is altogether too reductionist. ${ }^{14} \mathrm{He}$ does not assert that happiness is unimportant, but he rejects the claim that it is the only morally significant variable. ${ }^{15}$ According to Sen, utilitarianism asserts an identity between valuing and desiring, but there are more sources of value than the delivery of agreeable sensations or avoidance of disagreeable ones. Faced with the assertion that the evaluation of human lives must look more broadly than at the level of happiness they contain, Bentham might be left at a loss. What else could conceivably be relevant?

Sen's first presentation of the capability approach was in answer to the question "Equality of What? ${ }^{16}$ Capabilities and functionings were introduced as central variables in an effort to capture the strengths and avoid the weaknesses of 'welfare' and 'resources' respectively. Functionings are 'parts of the state of a person - in particular the various things he or she manages to do or to be in leading a life, ${ }^{17}$ while a person's capability is constituted by 'the alternative combinations of functionings the person can achieve, and from which she can choose one collection'. ${ }^{18}$ The core assertion of the approach is that 'the central feature of well-being is the ability to achieve valuable functionings'. ${ }^{19}$ Capability sets of possible 'functionings' were presented both as a more plausible criterion of 'well-being' than either utility or resources, ${ }^{20}$ and as the focus of investigation for egalitarian justice. More recently, Sen explicitly rejects both the characterization of the approach as a theory of justice, and the pursuit of 'equality of opportunity for well-being', ${ }^{21}$ describing his approach as 'no more than a perspective in terms of which the advantages and disadvantages of a person can be reasonably assessed'. ${ }^{22}$ In Sen's hands, the capability approach adopts a broadly consequentialist focus, but has self-consciously limited aspirations, and remains a partial moral theory. ${ }^{23}$ Over time, Sen has increasingly emphasized the centrality of liberty, describing his perspective as 'the freedom-based capability approach'. ${ }^{24}$ The focus on freedom shifts the emphasis from achievement (functionings) to opportunity (capabilities): the issue is not 'what I have been or done', but 'what I could reasonably have been or done'. ${ }^{25}$ 


\section{II.i. Capabilities and conditions for voluntary action}

In discussing the difficulties facing the poor man seeking to save his surplus income, Bentham commented 'the first article to look to is power'. ${ }^{26}$ The triad of knowledge, power and inclination, which Stark called Bentham's 'subjective' factors of production, ${ }^{27}$ constitute the necessary and sufficient conditions for voluntary action. ${ }^{28}$ To do something deliberately, I must want to do it, know how to do it, and be able - that is, have the power or capacity - to do it. Bentham's poor man might know about the benefits of postponing pleasures so that temporally distant pains could be avoided, and might exhibit an appropriate inclination to accumulate surplus earnings against the exigencies of old age, but, in the absence of accessible banking services, he also knows that he cannot secure his nest egg, and might as well return to the pub. ${ }^{29}$

Since the capability approach focuses on effective freedom, on what people are able to do, it is worth translating Bentham's conditions into the language of capability. The first condition for voluntary action is knowledge, which Bentham divides into knowledge of inducements and of means, or answers to the questions 'Why should I do this?' and 'How do I do this'. ${ }^{30}$ Knowledge is a source of power, since I cannot voluntarily perform an action unless I know how to do it. Knowledge is also a necessary condition for many of Sen's 'functionings'. In general, Bentham advocates the widest possible dissemination of knowledge. In 'Indirect Legislation', he dismisses the argument that such dissemination fosters criminality, countering that violent crimes of ignorance are more harmful than deceptive crimes involving differential knowledge, and arguing that, for instance, maintaining the poor in contented illiteracy would lead to loss of pleasure: ${ }^{31}$ 'in taking a fair estimate of the ballance of its [i.e. knowledge's] effects, the former [abuse of knowledge] ... is as much to be taken into account as the latter [use of knowledge]: but ... the former is occasional and confined: the latter is boundless and continual. ${ }^{32}$ Ceteris paribus, happiness increases with knowledge. ${ }^{33}$

Broadly, knowledge for Bentham means true belief (i.e. belief in accordance with the actual state of things), the product of experience, observation and reflection. ${ }^{34}$ For Bentham, the attraction of utilitarianism consisted in rendering moral discourse a matter of evidence, of investigation of facts. ${ }^{35}$ However, human beings are capable of believing in the existence of things that are not true (do not exist), and of disbelieving things that are true (do exist). He terms the former 'false consciousness' and the latter 'unconsciousness'. ${ }^{36}$ An individual's self-report of contentment with limited opportunities to exercise many functionings dependent 
on education or good health may be partly explained by 'lack of medical knowledge and by inadequate familiarity of comparative information', ${ }^{37}$ but such self-assessments are likely to be altered by gains in knowledge. Further, if self-assessment is underpinned by a misplaced conviction that prevailing arrangements are justified or immutable, false consciousness may contribute significantly to the phenomenon of adaptation.

Bentham divides the second condition, power, into power $a b$ intra - the range of actions a person might undertake leaving aside the influence of factors outside his/her person - and power $a b$ extra - determined by 'the condition and situation of the persons and things he has to do with'. ${ }^{38}$ Power $a b$ intra may be enhanced by knowledge, which is itself enhanced by education. In discussing the poor's disinclination to save, Bentham draws a close connection between power and inclination: 'Oftentimes where inclination appears wanting, and perhaps really is wanting, it is only because opportunity is wanting - that power, and consciousness of power, without which inclination can not so much as bring itself into life'. ${ }^{39}$

Power $a b$ extra has several varieties, namely physical, legal and intellectual. Physical power is given by control over resources, in particular, the all-purpose resource of money or wealth. Legal power is given either by threatening punishment against those who interfere with the exercise of power $a b$ intra, in which case 'power is no more than liberty', ${ }^{40}$ or by 'compelling [others] to afford assistance' - that is, by threatening punishment against those who fail to do so. ${ }^{41}$ Legal powers thus confer increased capacity either by providing protection from interference, or by using law to add the powers of others to those of the power-holder. Since human beings inhabit contexts replete with other human beings, their ability to order the actions of others in accordance with their will is a significant determinant of their power. Wealth enhances power by allowing the purchase of others' services or their obedience.

In one sense, Bentham's power simply is capacity, is effective freedom: my power comprises the complete range of actions between which I may choose. ${ }^{42}$ Again, ceteris paribus, happiness increases with power. Initially, Sen seemed to favour 'basic capability equality' as the goal of egalitarian justice. ${ }^{43}$ For his part, Bentham rejected the notion of equality of power as a goal of policy, arguing that it was incompatible with organized political life. ${ }^{44}$ Sen's increasing focus on capability as against functioning, on opportunity as against achievement, is intended to capture the conviction that 'the good life is inter alia a life of freedom'. ${ }^{45}$ As Rosen has done much to establish, Bentham was sensitive to the importance of liberty to human lives. Here, a single reason will be noted, namely the 
pain of being deterred by threat of punishment from doing whatever it might be I want to do: 'The whole course of legislation, though a necessary evil, is still an evil: the legislator can not stir, but what he does is felt in the shape of hardship and coercion somewhere. ${ }^{46}$

The third of Bentham's conditions, inclination, fits less easily with the terminology of capabilities. Inclination is will or desire. My desires do not coincide exactly with my capabilities, since there are activities or functionings that I might easily undertake but do not wish to, and others that I might very much wish to undertake but cannot. Bentham could hardly overlook inclination, since voluntary action definitionally involves exercise of will. In this connection, Sen advances another criticism, namely that utilitarianism shares (indeed, was largely responsible for) the assumption of modern economics that rational behaviour is self-interested. For Bentham, the goal of the prudentially rational agent is to maximize his/her net balance of pleasure over pain. Insofar as homo oeconomicus is a self-interested utility maximizer, Bentham would recognize his own characterization of typical human motivation. However, he did not assume that all motivation was egoistic. He recognized that sympathy for others, understood as desire for their well-being, could provide a motive for action, insisting only that since the pleasure I derive from awareness of their well-being is mine, the desire to promote that well-being is motivated by the prospect of a pleasure that is likewise mine. ${ }^{47}$

Sen rejects any notion of rationality which, by explaining sympathy in reference to the effect of others' well-being on my own, makes the operation of sympathy compatible with self-interest. ${ }^{48} \mathrm{He}$ concedes that 'the effect of "other-regarding" concerns on one's well-being has to operate through some feature of the person's own being, ${ }^{49}$ but insists that to limit evaluation of advantage to assessment of the level of individuals' well-being is to miss much that is of value. In particular, it is to overlook the difference between well-being and agency, the latter of which encompasses all goals adopted by an individual, and extends well beyond her well-being understood as a positive net balance of pleasure over pain..$^{50}$ This is a serious indictment, to which a possible Benthamic response, deploying the subordinate end of security, will be considered in Section III.

Sen joins many critics who have noted that not all human actions aim directly at happiness: some are done out of duty, some for other goals, some without any thought for the consequences. Bentham himself recognized many actions as the unreflective product of habit, or a desire to follow the herd, or not to think too hard, ${ }^{51}$ but such actions are hardly products of rational reflection. In responding directly, Bentham 
might argue that the analysis finishes too quickly. If I am motivated by the desire to 'do the right thing' though the heavens fall, he might ask how I would feel if I acted otherwise, and hypothesize that I would feel pain, and that it is in order to avoid this sensation that I so act. He also recognized that, especially when an action did not impact directly on the well-being of an individual or on those close to him/her, that individual's share in the universal interest could motivate actions from 'public spirit'. Insofar as public spirit and individual interest pulled in the same direction, actions often arose 'from a little of the one and a little of the other put together'. ${ }^{52}$ Finally, he discussed cases of heroic self-sacrifice, in which individuals subjected themselves to great pain or death in order to benefit others. ${ }^{53}$ In such cases, he would have to argue that the pains such individuals would feel in consequence of not making the sacrifice would be worse than death, but he would also doubtless point out that such cases were extraordinarily rare. ${ }^{54}$

\section{II.ii Conversion factors: circumstances influencing sensibility}

The exercise of many of Sen's capabilities - that is, many of his functionings - are mediated by 'conversion factors' that occupy the space between consumption of resources and experience of sensations. ${ }^{55}$ Sen's critique of 'equality of resources' rests on the latter's incapacity to take account of such factors, but Bentham's utilitarianism appears immune to this criticism. Bentham categorized conversion factors as 'circumstances influencing sensibility'. ${ }^{56}$ Almost every adducible fact about individuals is capable of acting as such a circumstance. Bentham listed 32 of them, ranging from internal physical or mental states, such as health, knowledge and bent of inclination, to external but still personal factors, such as connections in the way of sympathy and antipathy and pecuniary circumstances, to very broad factors like climate and form of government. ${ }^{57}$ If, through the influence of these circumstances, people differ in their capacities for deriving well-being, how should moral theories take account of the variations?

On one hand, insofar as circumstances influencing sensibility alter the value of sensations, an accurate calculation of that value must take them into account. On the other, not only can no general rule take cognizance of all differences in individual sensibility, but the legislator is in no position to garner the data necessary to reveal those differences. Bentham begins with a presumption of equality in sensibility, itself 
derived from lack of particular knowledge: 'Of individuals it is clear that the legislator can know nothing: concerning those points of conduct which depend upon the particular circumstances of each individual ... he can determine nothing to advantage. ${ }^{58}$ Bentham's legislator commences by setting conversion factors aside altogether, and presuming that individuals have an equal capacity for happiness. ${ }^{59}$ However, he envisaged that some circumstances which 'apply indiscriminately' to discrete categories of persons could be 'directly and pretty fully provided for by the legislator'. ${ }^{60}$ His list of such circumstances included bodily imperfection, insanity, sex, rank, climate, lineage, religion and age.

In regard to other circumstances, which admitted 'an infinite variety of degrees', the legislator was at a stand. However, Bentham contrasted the generic knowledge available to the legislator with the detailed familiarity with the circumstances influencing particular sensibilities achievable by the judge, who was given responsibility for fine-tuning the application of the penal-code according to circumstances that:

cannot be fully provided for by the legislator; but, as ... the degree in which they take place is capable of being measured, provision may be made for them by the judge, or other executive magistrate, to whom the several individuals that happened to be concerned may be made known. ${ }^{61}$

It is tempting to assume that public officials, or 'executive magistrates', in a position, like the judge, to acquire knowledge of individual circumstances, might be equally obliged to make provision for the impact of such circumstances in applying public policy.

\section{The subordinate ends of legislation and capabilities}

For Rosen, Bentham's pursuit of utility was largely indirect. ${ }^{62}$ The legislator achieves the maximum of happiness, the 'paramount end', by directly pursuing instead four subordinate ends - subsistence, security, abundance and equality: 'The superior end consists in the maximum of all four put together. ${ }^{163}$ The achievement of discrete subordinate ends might be traded off, but only against the greater achievement of the others: 'No sacrifice to be made of any one but in subserviency to some other of the four. ${ }^{64}$

In contrast to Bentham's theory of punishment - which concerns partly the direct infliction of the real entities (pains) and partly their 
indirect infliction through the proxy of financial penalties - his discussion of distributive justice focuses on the distribution of fictitious entities, that is, rights and obligations. ${ }^{65}$ In terms of the distinction between welfare and resources, the latter discussion is entirely resourcist, in that the rights in question are rights to things or services, or, in short, to property, while rights and obligations are also fictitious proxies for real sensations. ${ }^{66}$ As Bentham noted, three of his subordinate ends - subsistence, abundance and equality - 'are conversant with the same matter; to wit, the matter of wealth', ${ }^{67}$ that is resources: 'all these subject-matters are, with reference to the individual in question, distinct from him, and exterior to him'. The fourth end, security, deals partly with similar subject matter, but also includes the individual's body (the site of experience of pain and pleasure), reputation and condition in life. ${ }^{68}$

When Nussbaum describes the task of politics as 'distributing the conditions for a good life', ${ }^{69}$ she is echoing Bentham's description of the task of the civil law. The coincidence is not accidental, insofar as Bentham's subordinate ends constitute his enumeration of objective human interests. In Postema's words, the subordinate ends 'are the universal goods each member needs whatever her (other) interests are. ${ }^{70}$ Despite his subjectivist epistemology, Bentham believes that human beings share universal interests. Although human tastes are idiosyncratic, 'the feelings of men are sufficiently regular to become the object of a science or an art'..$^{7}$

There are similarities between Nussbaum's use of a substantive conception of human nature to ground a list of objectively valuable capabilities, and Bentham's list of subordinate ends. Bentham might endorse Nussbaum's defence of 'essentialism', and the effort 'to begin by considering certain perfectly general conditions of human life that appear to be common to all human societies. ${ }^{72}$ Of course, the general condition crucial for Bentham was the capacity to experience pain and pleasure. Although Nussbaum dismisses 'a life organized around the activity of sense-perception' as 'merely animal', ${ }^{73}$ not only did she recognize in an early article that 'the aversion to pain as a fundamental evil is a primitive ... unlearned part of being a human animal', but included 'being able to avoid unnecessary and nonbeneficial pain and to have pleasurable experiences' in her list of 'Basic Human Functional Capabilities', though it disappears in later versions. ${ }^{74}$

Bentham's subordinate ends, however, constitute neither 'a thick vague theory of the good', ${ }^{75}$ nor even a 'thin theory of the good', ${ }^{76}$ but rather, perhaps, a thin theory of the bad. Rosen consistently underlines the negative nature of the legislator's task: 'To have security is to 
be free from something, for instance invasion, illness, or interference. ${ }^{77}$ For Bentham, 'The care of providing for his enjoyments ought to be left almost entirely to each individual; the principal function of government being to protect him from sufferings. ${ }^{78}$ Similarly, in describing the maximum happiness under the perfection of laws, Bentham asked: 'To what will the happiness arising from all this amount? It may be described as the absence of a certain quantity of evil. It will arise from the absence of a part of the different evils to which human nature is subject. ${ }^{79}$

Such an approach opens a line of response to the criticism that utilitarianism's commitment to direct maximization of happiness comes at the cost of a disregard for individual entitlements. Bentham's security might loosely be described as liberty under law. A charge made by commentators on Adam Smith is that Benthamite utilitarianism's error lies in its positive pursuit of the maximum happiness, as contrasted with Smith's 'negative utilitarianism'. ${ }^{80}$ In fact, Bentham and Smith entirely agree on the primarily negative task of law: to protect each against depredation by our fellows. For Bentham, offences against individuals involve damage to their person, property, reputation or condition in life - that is, to their security. Government protects individuals 'by creating rights which it confers upon individuals: rights of personal security; rights of protection for honour; rights of property; rights of receiving assistance in case of need'. ${ }^{81}$

Thanks to Rosen, Kelly and Dube, ${ }^{82}$ it is no longer plausible to assert that Bentham lacks appreciation of the value to human lives (and human happiness) of liberty. Bentham would agree with Sen that the ability to walk the streets without fear of being mugged was a good thing, and further that 'we are looking for effective power', rather than direct control over the prevention of mugging. ${ }^{83} \mathrm{He}$ might object to Sen's description of the benefit in terms of 'our freedom being well served', since it is the coercive restraint of the mugger's freedom that serves our security. Rosen provided a magisterial analysis of Bentham's understanding of liberty, and of his argument that erecting political systems on the basis of a principle of liberty was an incoherent enterprise, since liberty - that is, the absence of coercion - and government - that is, coercion - are mutually exclusive concepts. ${ }^{84}$

Sen objects to utilitarianism for its disregard of agency: 'A person's "agency freedom" refers to what a person is free to do and achieve in pursuit of whatever goals or values he or she regards as important. ${ }^{85}$ The poverty of the exclusive utilitarian focus on welfare is allegedly revealed in its failure to enquire after the capability of individuals to pursue anything beyond their own well-being. ${ }^{86}$ Since other goals and values matter, 
'neither justice, nor political or moral evaluation, can be concerned only with the overall opportunities and advantages of individuals in a society'. ${ }^{87}$ For Bentham, well-being is indeed the sole ultimate end of action. However, the primarily negative focus of the legislator's task accommodates agency goals and values as central elements of individual security, provided only that their pursuit does not violate the security of others. If my agency goals do involve threatening that security, my agency freedom will rightly be restrained by coercive law. In short, for Bentham, a considerable degree of 'agency freedom' is a central element of well-being. Given the importance that he ascribed to security in all its manifestations, the Rawlsian liberties of person, expression and association would be guaranteed by Bentham's codes, as would freedom of the press, a necessary condition of security against misrule.

Rosen argues that security is by far the most important subordinate end ${ }^{88}$ and Bentham himself often says similar things. ${ }^{89}$ Sometimes, however, he accords this accolade to subsistence. ${ }^{90}$ These two primary subordinate ends both encompass many different functionings. Thus, subsistence refers not simply to the functioning of being well-nourished (where 'well' means 'sufficient to maintain health'), ${ }^{91}$ but also - at a minimum - to those of being well-housed and well-clothed. For Bentham, the brute fact is that most of humanity will spend their lives in a condition not far elevated above subsistence level:

Impossibility of raising the wages of ordinary labour beyond mere subsistence. The state of the poorest is an acquisition in comparison of the savage state, which is the natural state. Equality is procured: 1. By raising up. 2. By pulling down. 1. Raising the bulk higher than they are is impossible. 2. Pulling down others is mischievous. ${ }^{92}$

Most of us will therefore never, in Aristotelian terms, be liberated from the kingdom of necessity. The better news for the legislator is that if $s /$ he provides a conditional guarantee of subsistence to all, s/he will have broken the back of the task, because the most fruitful sources of pleasure the pleasures of eating, drinking, sex and rest, and the vicarious pleasure of knowing those we love are enjoying such pleasures - are enjoyed by all whose subsistence is secure. ${ }^{93}$ Further, notwithstanding the fact that wealth is an all-purpose tool for acquiring instruments of pleasure, once subsistence is secured, wealth itself is characterized by rapidly diminishing marginal utility. ${ }^{94}$

The third subordinate end, abundance, consists in the social surplus existing after the demands of subsistence have been satisfied. Although 
Bentham cautions against mistaking wealth for happiness, ${ }^{95}$ abundance qualifies as a subordinate end by virtue of its status as the source of funds for the institutions necessary to maintaining security on the one hand, and those necessary to maintaining the conditional assurance of subsistence on the other: 'the manufactories of luxury are offices of insurance against want'. ${ }^{96}$

The final subordinate end, equality, enters Bentham's theory in at least two ways. The first concerns the implications for the distribution of any good of diminishing marginal utility, which indicate that, ceteris paribus, an equal distribution will maximize happiness. The second involves what Postema calls Bentham's 'individualist conception' of happiness. The feelings of human beings matter because they are felt by people attempting to live their lives: 'If these experiences are abstracted from the meaning they have within the lives of individual human beings they lose utterly their moral significance. ${ }^{97}$ From the legislator's perspective, to paraphrase Dworkin, human lives matter, and matter equally. ${ }^{98}$ It is true that both abundance and equality are, for Bentham, outranked in direct competition with either subsistence or security. Both, however, are properly understood as ends of legislation. Without abundance, there are no resources to meet either the demands of security or to offer security of subsistence for more than the shortest periods. Without an explicit recognition of equality of claim to consideration in public policy, what follows? Not only the likelihood of significant social conflict and consequent unhappiness, but the closure of the only route to generalization of moral claims. No claim to systematic priority for my happiness over that of others can be generalized, but a claim to equal priority can be. With Rosen, 'the only interests that can be maximized for everyone are those that everyone shares', hence the 'greatest happiness in politics and legislation effectively means the maximization of equal security to all members of society'. ${ }^{99}$

\section{Bentham and adaptation}

For both Sen and Nussbaum, one major weakness of utilitarianism involves the way in which subjective assessments of happiness are influenced (perhaps even determined) by existing social expectations of the sorts of lives appropriate to particular subgroups of the population:

Desires and satisfactions are highly malleable. ... The poor and deprived frequently adjust their expectations and aspirations to the low level of life they have known; thus their failure to express 
dissatisfaction can often be a sign that they really do have enough. This is all the more true when the deprivations in question include deprivation of education and other information about alternative ways of life. ${ }^{100}$

The limited opportunities available in many countries to women make it prudentially rational for them to cut their cloth in accordance with those limits, avoiding the pain of disappointment by adopting a sort of self-denying ordinance. Accepting reports of contentment from such groups is endorsing the perpetuation of injustice, but utilitarianism 'is bound by its very commitments to an uncritical validation of the status quo', ${ }^{101}$ especially since consciousness-raising measures intended to facilitate demands for change will necessarily lead to an increase in dissatisfaction:

People who ... become aware of the variety of human societies and lose the isolation of ... their 'encapsulated' condition frequently feel pain: both the pain of a new dissatisfaction with current arrangements and the pain of reflection itself. If one is committed to measuring development in terms of utility ... one will be bound to judge that self-understanding is inimical to development, in such cases. ${ }^{102}$

Now, Bentham was perfectly aware of the effects of lived experience and social referents on aspiration. In his poor law writings, he distinguished the category 'Past prosperity hands' and, in recognition of their habituation to comparative luxury, sought to lighten their load in the workhouse. ${ }^{103}$ Elsewhere, he appealed to the influence of relative deprivation in limiting the aspirations of the poor, thereby reducing the pains they might feel in comparing their life chances with those of the rich. To those at the bottom of the scale, its summit was too remote to be relevant to their prospects: 'So far from making these comparisons, they do not dream of them; they are not tormented with impossibilities. ${ }^{104}$

Since pleasure and pain are sensations, we are each the authority on our own perception of them. Bentham makes the adaptation point in reverse in his discussion of slavery: 'It is absurd to reason as to the happiness of men, otherwise than with a reference to their own desires and feelings. It is absurd to seek to prove by calculation, that a man ought to be happy when he finds himself miserable. ${ }^{105}$ In relation to Nussbaum's argument that measures to change self-perceptions of disadvantaged groups will increase their pain, Bentham would admit the likelihood, and agree that such pains, in and of themselves, count against justification of the 
measures, as would the pains - felt by those favoured by current orthodoxies - likely to ensue from a post-consciousness-raising demand for reform. Pain, regardless of prejudicial origin, is pain, and as such is relevant to utilitarian calculation.

However, two different (and not necessarily consistent) responses might be made. First, insofar as the Rosen-Kelly interpretation is correct, since Bentham is interested in distributing equally the conditions of happy lives (without prejudicing security), the pains reflected in a decrease in satisfaction levels are themselves strictly irrelevant. Further, if Bentham is interested in the conditions of interest-formation, as well as those of interest-pursuit, there may well be a case for taking educative measures to combat the self-limitation of aspiration, by increasing knowledge, thus reducing both 'false-consciousness' and 'unconsciousness', and thereby increasing power and changing inclinations.

Alternatively, if the legislator is committed to direct utility calculations, it is nevertheless incorrect to assert that s/he 'will be bound' therefore to eschew efforts to change attitudes, since, as Bentham might say, the calculation remains incomplete. If consciousness-raising measures have costs, they also have benefits - increased knowledge and self-confidence, and, in time, increased happiness. ${ }^{106}$ As ever, the correct choice depends upon the net balance of probable pains and pleasures consequent upon the choice, or, with Bentham: 'The clear utility of the law will be as its abstract utility, deduction made of the dissatisfaction and other inconvenience occasioned by it. ${ }^{107}$ Now, some of Bentham's examples of variations from abstract utility that might be viewed as 'indifferent' - as having no net effect on happiness - are rebarbative. ${ }^{108}$ As argued elsewhere, given his seeming endorsement of cultural practices that, for men's convenience, severely curtailed the options of women, just what it takes to render any practice clearly mischievous is less than clear. ${ }^{109}$ The point, however, is that it is wrong to conclude that Bentham must uncritically accept prevailing opinion, regardless of content. It was always a matter of doing the sum, and setting the benefits of a policy against the costs, including those of a collision with prevailing beliefs.

Where the costs of challenging adaptive preferences are high, the balance of utilities might forbid reform. ${ }^{110}$ However, in 'Place and Time', Bentham concluded that if popular opinion was unremittingly hostile to a reform that promised a clear gain in human well-being, the legislator must override it: 'The welfare of all must not be sacrificed to the obstinacy of a few; nor the happiness of ages to the quiet of the day. ${ }^{111}$ After all, as Bentham noted, the dissatisfaction consequent upon change was likely to 
be temporary, the benefit permanent. For a legislator adopting any more than the shortest time horizon, the benefits had every chance of exceeding the costs.

It is not the case that, for Bentham, all preferences or judgements of value are equally worthy of respect: 'what matters it whether a practice be originally prevalent, or at this time prevalent, when by considerations drawn from the influence of it on human feelings it can be shewn to be proper, indifferent or improper?"112 He notes that, 'Every nation is liable to have its prejudices and its caprices, which it is the business of the legislator to look out for, to study, and to cure. ${ }^{113}$ If the legislator believes that prevailing beliefs are mistaken, $\mathrm{s} /$ he has no ultimate recourse but to appeal to evidence. In so doing, Bentham himself recommends a cautious approach, avoiding, if possible, head-on attacks on prejudice. ${ }^{114}$ Prejudicial judgements, judgements made without evidence, are exposed by examination of their rationale. As Bentham noted, in admitting that the pain suffered by homophobes at the thought of pleasure derived from consensual homosexual sex acts was 'unquestionably to be placed to the account of the mischief of the offence, and this is one reason for the punishing of it', such pain might be 'assuaged and reduced to such a measure as to be no longer painful only in bringing to view the considerations which shew it to be ill-grounded'. ${ }^{115}$

Since Sen concedes that individual valuations depend partly on social valuations, implementation of the capability approach will also be 'culture-dependent, especially in the weighting of different capabilities'. ${ }^{116}$ As Sumner notes, the subjectivity of cultural judgements threatens to hoist the approach on an adaptation petard of its own making. ${ }^{117}$ Sen's resolution involves appeal to collective discussion, and collective political judgement. Such collective evaluation involves deliberative exchange of reasons in an avowedly pluralistic democratic public sphere, informed by plural bases of information, and modelled on Smith's impartial spectator. ${ }^{118}$ Bentham would dissent from neither the demand for reasoned assessment, nor its location in the free exchange of opinions in a democracy. Without endorsing the indictment that the capability approach legitimizes sacrificing individual preferences to socially imposed values, ${ }^{119}$ sympathetic commentators question the methods for making public judgements. ${ }^{120}$ While the early Bentham assumed that the motivation of political power-holders was appropriately utilitarian, the later radical democrat Bentham explicitly viewed the interest of the governing few as diametrically opposed to that of the governed many, ${ }^{121}$ and spent a decade designing an institutional blueprint capable of resolving 
this conflict, central to which were institutions by which 'minimal standards of representation' and thereby 'public reasoning and democracy' might be guaranteed. ${ }^{122}$

In part, Sen's hostility to utilitarianism is traceable to his own moral pluralism. ${ }^{123}$ Of course, Bentham would view the admission of value pluralism as destructive of objectivity in morals, as the upshot of an unreflective intuitionism he called the principle of sympathy and antipathy. While all human experience was inescapably subjective, Bentham's claim was that the principle of utility, through its connection with the real entities of pleasure and pain, offers an objective criterion for the evaluation of moral claims. Moral engagement on any other basis was reducible to the bare statement of subjective preference. ${ }^{124}$ It might be argued in response that moral pluralism does not of itself rule out consensus on, for instance, the idea that unnecessary pain is a significant harm, and that harm should be avoided wherever consistent with whatever balancing of plural values constitutes doing the right thing in particular cases. Bentham might repeat that moral pluralism cannot provide consistent, empirically accessible and objective decision-making criteria, but, as Crisp notes in a sympathetic and nuanced discussion, utilitarianism itself is hardly free from ad hoc judgements in calculating incommensurable variables, and it remains open to the pluralist 'to appeal to the necessity for judgement in any reasonable form of theoretical ethics'. ${ }^{125}$

Value pluralist or not, Sen commits himself to a limited form of objectivity in moral evaluation. He praises Smith's device of the impartial spectator for widening moral horizons by bringing reasoned assessment to bear on unreflective, parochial preferences. One example to which Sen appeals is Smith's condemnation of the role of custom in legitimizing infanticide in ancient Greece. ${ }^{126}$ For Smith, such practices 'shock the plainest principles of right and wrong', and could be explained only by the barbarity of the times. Smith dismissed philosophical defences of infanticide as 'far-fetched considerations of public utility', and concluded, 'When custom can give sanction to so dreadful a violation of humanity, we may well imagine that there is scarce any particular practice so gross which it cannot authorize. ${ }^{127}$ Bentham would dissent from the idea that infanticide was necessarily a heinous crime, and defended it, particularly in circumstances of population pressure, and specifically on the part of unmarried mothers faced with forfeiture of reputation and consequent destruction of future happiness. His utilitarian rationale contrasted the probable consequences to the mother of attempting to rear a child alone with the absence of expectation on the infant's part or alarm on the part of other infants. ${ }^{128}$ For present purposes, the crux is not 
the moral status of neonates, but the way in which Sen's example of the impartial spectator perspective as the corrector of localism's errors seems peculiarly ill-chosen, since the 'enlightened' attitude endorsed by Smith and Sen is itself open to criticism for its parochialism. As Singer notes, infanticide has been a relatively common and accepted practice across cultures and across history: 'from a cross-cultural perspective it is our tradition ... that is unusual in its official morality about infanticide'. ${ }^{129}$ Bentham would recognize the utility of cross-cultural comparisons in extending our moral horizons, but might argue that Smith's impartial spectator, unless informed by the principle of utility, was likely to issue the wrong prescriptions.

Sen seeks a middle route between 'the Charybdis of [objectivist] overrigidity' and the 'Scylla of subjectivist variability'. ${ }^{130}$ Although Bentham's epistemology was subjectivist, he too sought an objective basis for a moral discourse conducted on the basis of empirically verifiable assertions about the experience of pain or pleasure by sentient beings. Like Sen and Nussbaum, he recognized choice as a constitutive element of well-being, and would baulk only at ascribing intrinsic value to anything but pleasure. Like Sen and Nussbaum, Bentham was committed to widespread publicity of both public policy and its rationale. Sen's reliance on public evaluation of capabilities provides some defence against the charge that his approach is one more variant of sympathy and antipathy, a bare statement of approbation coupled with a demand that others' attitudes should accord with our own, and that where they do not, coercive public power should ensure that their behaviours at least do so accord. Bentham too sought to subject the exercise of public power to continuous reflective assessment by public opinion. For Sen, 'reasoned valuation' insures the capability agenda against hijack by oppressive social consensus. Bentham might counter that only discussion conducted in terms of the real entities of pleasure and pain can offer an objective basis for rational consensus, and that, thanks to human idiosyncrasy, any conceivable functioning might be vital to the life plan of particular individuals. He might argue that the subordinate ends of legislation, on the one hand, and their foundation in human feelings on the other, offer a simpler, more universal formula for capturing the essential building blocks of human welfare (or, more accurately, essential ramparts against human ill-fare). A final hope, the fulfilment of which would make Fred Rosen very happy, is that contemporary philosophers might be prompted to return to the sources of classical utilitarianism (and to Bentham in particular), and that engagement with those sources in context might not only confound some preconceptions 
but deliver additional insights. Crisp notes that while utilitarianism and 'reflective non-egoistic pluralism' seem alike incapable of refuting the other, 'it is not entirely vain to hope that, if we understood ourselves and our history much better, there would be greater agreement in ethics, nor for the utilitarian to believe that there would be greater convergence on utilitarianism itself' ${ }^{131}$

\section{Notes}

1. See, for instance, Amartya Sen, 'Reason, Freedom and Well-being', Utilitas 18 (2006), 82; Amartya Sen, The Idea of Justice (London: Penguin, 2009), 275n, 361-3, 367. Sen does, however (Idea of Justice, xvi), identify Bentham with a tradition of social choice theory of which he approves, and which rejected the search for 'perfectly just social arrangements' in favour of 'making comparisons between different ways in which people's lives may be led'.

2. See, for instance, Leonard W. Sumner, 'Utility and Capability', Utilitas 18 (2006): 1-19; Mozaffar Qizilbash, 'Capability, Happiness and Adaptation in Sen and J. S. Mill', Utilitas 18 (2006): 20-32; Mozaffar Qizilbash, ‘Amartya Sen's Capability View: Insightful Sketch or Distorted Picture?', in The Capability Approach: Concepts, Measures and Applications, eds. F. Comin, M. Qizilbash and S. Alkire (Cambridge: Cambridge University Press, 2008), 56-62; Robert Sugden, 'What We Desire, What We Have Reason to Desire, Whatever We Might Desire: Mill and Sen on the Value of Opportunity', Utilitas 18 (2006): 33-51; Jonathan Riley, 'Liberal Rights in a Pareto-optimal Code', Utilitas 18 (2006): 61-79.

3. See, for instance, Sen, Idea of Justice, 218-9; Amartya Sen, 'Well-Being, Agency and Freedom', Journal of Philosophy 82 (1985): 192-5; see also Martha C. Nussbaum, Frontiers of Justice: Disability, Nationality, Species Membership (Cambridge, Mass.: Harvard University Press, 2006), 71-4.

4. See Amartya Sen, 'Equality of What?', in The Tanner Lectures on Human Values: I (Cambridge: Cambridge University Press, 1980), 217; Sen, Idea of Justice, 274-6, 282-3; Martha C. Nussbaum, Sex and Social Justice (New York: Oxford University Press, 1999), 149-52; Nussbaum, Frontiers of Justice, 73-4, 282-3.

5. See, for instance, Jeremy Bentham, 'A Comment on the Commentaries', in A Comment on the Commentaries and A Fragment on Government, eds. J. H. Burns and H. L. A. Hart (London: Athlone, 1977), 67; Jeremy Bentham, 'Deontology', in Deontology, Together with A Table of the Springs of Action and Article on Utilitarianism, ed. A. Goldworth (Oxford: Clarendon Press, 1983), 125.

6. See Jeremy Bentham, Preparatory Principles, eds. D. G. Long and P. Schofield (Oxford: Clarendon Press, 2016), 130-1; Bentham, 'Deontology', 147-8.

7. Jeremy Bentham, 'Not Paul, but Jesus: Vol. III. Doctrine', University College London collection of Bentham manuscripts (henceforth UC), clxi, 224. http://discovery.ucl.ac.uk/1392179/3/ npbj.pdf (accessed 19 March 2019).

8. See Bentham, 'Not Paul, but Jesus', UC, clxi, 218: 'By the ... principle of utility - is designated that doctrine by which endeavours are used to engage men on every occasion to pursue that course of action by which, in so far as happiness is concerned, the greatest quantity of happiness, say or well-being, will be produced.' A rare discussion in which Bentham distinguishes happiness from well-being occurs in 'Deontology', 130, where he notes that in common language the word 'happiness' appears less appropriate than the word 'well-being' to indicate a net balance of pleasure over pain because 'it seems not only to lay pain in all its shapes altogether out of the account', but to assume pleasures to have been experienced in 'superlative degree'.

9. Jeremy Bentham, Supply without Burthen; or Escheat vice Taxation (London: J. Debrett, 1795), 78 (Jeremy Bentham, Jeremy Bentham's Economic Writings, 3 vols, ed. W. Stark (London: Allen \& Unwin, 1952-4), i, 305-6). See also Jeremy Bentham, 'A Protest against Law Taxes', in Writings on Political Economy: Vol. I, ed. M. Quinn (Oxford: Clarendon Press, 2016), 290.

10. Bentham, 'Method of an Institute of Political Economy', UC, xvii, 175 (Jeremy Bentham's Economic Writings, iii, 308). 
11. See Bentham, 'Deontology', 130-5.

12. See Jeremy Bentham, An Introduction to the Principles of Morals and Legislation, eds. J. H. Burns and H. L. A. Hart (Oxford: Clarendon Press, 1996) (henceforth IPML), 39-41.

13. Bentham, 'Not Paul, but Jesus: Vol. III', 245.

14. See Amartya Sen, Commodities and Capabilities (New Delhi: Oxford University Press, 1999), 14-5, 17-21; Sen, 'Well-Being, Agency and Freedom', 174-5, 186-200; Sen, Idea of Justice, 282-90.

15. See Sen, 'Well-Being, Agency and Freedom', 186; Sen, Idea of Justice, 273.

16. See Sen, 'Equality of What?'.

17. Amartya Sen, 'Capability and Well-Being', in The Quality of Life, eds. M. C. Nussbaum and A. Sen (Oxford: Clarendon Press, 1994), 31. See also Sen, Commodities and Capabilities, 7; Amartya Sen, 'Human Rights and Capabilities', Journal of Human Development 6 (2005): 154.

18. Sen, 'Capability and Well-Being', 31.

19. Sen, 'Well-Being, Agency and Freedom', 200. See also Sabina Alkire, 'Why the Capability Approach?', Journal of Human Development 6 (2005): 122.

20. See Sen, Commodities and Capabilities, 37-45.

21. See Gerald A. Cohen, 'Equality of What? On Welfare, Goods, and Capabilities', in The Quality of Life, eds. M. C. Nussbaum and A. Sen (Oxford: Clarendon Press, 1994), 9-29. See also Peter Vallentyne, 'Capabilities versus Opportunities for Well-Being', Journal of Political Philosophy 13 (2005): 359-71.

22. Sen, Idea of Justice, 296-7.

23. See Sen, 'Well-Being, Agency and Freedom', 200. Sen argues (Idea of Justice, 240-1) that the approach can deliver substantive judgements, although they remain partial and imperfectly transitive, since not all capacities or functionings are commensurable. For Nussbaum, the approach is simultaneously the core of a 'political' conception of justice, a source of political rights claims, and a guide to public policy: see Nussbaum, Frontiers of Justice, 75-81, 92-5; Martha C. Nussbaum, 'Capabilities as Fundamental Entitlements: Sen and Social Justice', Feminist Economics 9 (2003): 33-59.

24. See Sen, Idea of Justice, 231; Amartya Sen, 'Justice: Means versus Freedoms', Philosophy and Public Affairs 19 (1990): 114.

25. The priority of capability is explicit in Nussbaum: see Martha A. Nussbaum, 'Human Functioning and Social Justice: In Defense of Aristotelian Essentialism', Political Theory 20 (1992): 221; Martha C. Nussbaum, Women and Human Development: The Capabilities Approach (Cambridge: Cambridge University Press, 2000), 87. See also Ingrid Robeyns, 'The Capability Approach: A Theoretical Survey', Journal of Human Development 6 (2005): 101. There is no space to outline the main lines of critique applied to the capability approach, but see, for instance, Robert Sugden, 'Welfare, Resources, and Capabilities: A Review of "Inequality Re-examined" by Amartya Sen,' Journal of Economic Literature 31 (1993): 1947-62; Cohen, 'Equality of What? On Welfare, Goods, and Capabilities', 20-6; Vallentyne, 'Capabilities versus Opportunities for Well-Being'; Sumner, 'Utility and Capability'; Séverine Deneulin, 'Perfectionism, Paternalism and Liberalism in Sen and Nussbaum's Capability Approach', Review of Political Economy 14 (2002): 497-518.

26. See Jeremy Bentham, Writings on the Poor Laws, I, ed. M. Quinn (Oxford: Clarendon Press, 2001), 86.

27. See Werner Stark, 'Jeremy Bentham as an Economist II. Bentham's Influence', Economic Journal 56 (1946): 598-9. See also Marco E. L. Guidi, “Shall the Blind Lead Those Who Can See?" Bentham's Theory of Political Economy', in Perspectives on the History of Economic Thought Volume III, ed. D. E. Moggridge (Aldershot: Edward Elgar, 1990), 15-18.

28. See Jeremy Bentham, 'Indirect Legislation', UC, lxxxvii, 7.

29. See Jeremy Bentham, Writings on the Poor Laws: I, ed. M. Quinn (Oxford: Clarendon Press, 2001), 84-5: 'The more closely we examine ... the circumstances of the Poor, the more thoroughly we shall be satisfied ... that if the poor man is to have a safe, and constant, and ready Banker, it is government that must find him one.'

30. See Bentham, 'Indirect Legislation', UC, lxxxvii, 95.

31. See, for instance, T. Ruggles, The History of the Poor; Their Rights, Duties, and the Laws Respecting Them, 2 vols (London: J. Deighton, 1793-4), ii, 180-1.

32. Bentham, 'Indirect Legislation', UC, lxxxvii, 101.

33. See Jeremy Bentham, Rationale of Judicial Evidence, Specially Applied to English Practice, ed. J. S. Mill, 5 vols (London: Hunt \& Clarke, 1825), i. 209 (Jeremy Bentham, The Works of Jeremy 
Bentham, published under the Superintendence of his Executor, John Bowring, 11 vols [Edinburgh: William Tait, 1843] [henceforth Bowring, vi, 264).

34. See Jeremy Bentham, The Book of Fallacies, ed. P. Schofield (Oxford: Clarendon Press, 2015), 205.

35. See UC, $1 \mathrm{xx}, 22$.

36. See $I P M L, 75$

37. Sen, Idea of Justice, 284

38. Bentham, 'Indirect Legislation', UC, lxxxvii, 89. This division foreshadows that drawn by Nussbaum between 'internal' and 'combined capabilities': see Nussbaum, Sex and Social Justice, 44.

39. Bentham, Writings on the Poor Laws: I, 86. A parallel might be drawn with the position of the poor, and poor women in particular, in developing countries, while the inference that enhancing power is likely to stimulate previously dormant desires is equally applicable to both cases.

40. See Bentham, 'Manual of Political Economy', in Writings on Political Economy: I, 177.

41. See Bentham, 'Manual of Political Economy', 177.

42. See Sen, 'Well-Being, Agency and Freedom', 208: 'A person's freedom may well be assessed in terms of the power to achieve chosen results.'

43. See Sen, 'Equality of What?', 218-20.

44. See, for instance, 'Principles of the Civil Code', Bowring, i, 303: 'The laws never cease establishing inequalities, since they cannot bestow rights upon any, without imposing obligations on others.'

45. Sen, 'Well-Being, Agency and Freedom', 202.

46. Bentham, 'Method of an Institute of Political Economy', UC, xvii, 167 (Jeremy Bentham's Economic Writings, iii, 311).

47. See Bentham, 'A Table of the Springs of Action: Marginals', in Deontology, Together with A Table of the Springs of Action, and Article on Utilitarianism', 36.

48. See Sen, Idea of Justice, 178-93; and Amartya Sen, Rationality and Freedom (Cambridge, Mass.: Harvard University Press, 2002), 22-33.

49. Sen, 'Capability and Well-Being', 36.

50. See Sen, 'Well-Being, Agency and Freedom', 203.

51. See Michael Quinn, 'Jeremy Bentham, "The Psychology of Economic Man”, and Behavioural Economics', OEconomia 6 (2016): 3-32.

52. UC, iii, 397. Drafted for 'Observations by Sir Frederick Morton Eden ... on the Annuity Note Plan ... with Counter-Observations by the Author of the Plan'.

53. See Gerald J. Postema, 'Interests Universal and Particular: Bentham's Utilitarian Theory of Value', Utilitas 18 (2006): 124-5.

54. See Jeremy Bentham, 'Greece: Principles of Legislation as to Constitutional Law', in Securities against Misrule and Other Writings for Tripoli and Greece, ed. P. Schofield (Oxford: Clarendon Press, 1990), 185.

55. See Sen, 'Well-Being, Agency and Freedom', 196, 198-9; Sen, Idea of Justice, 254-6.

56. See Bentham, IPML, 51-73.

57. There are similarities between Bentham's discussion and the three-fold division of conversion factors made by Robeyns, 'The Capability Approach', 99. It is worth noting that all three of Bentham's conditions for voluntary action appear in some form among the circumstances influencing sensibility. The central difference between his two enumerations relates partly to the distinction between active and passive modes of experience, between doing and being-done-to. As noted, to do something voluntarily I must know how to do it, be able to do it and want to do it, but the extent of my knowledge and power, and the nature of my tastes (my 'bent of inclinations'), impact directly on my experience of sensations in response to particular stimuli.

58. Bentham, IPML, 290.

59. See Jeremy Bentham, 'Considerations d'un Anglois sur la composition des Êtats-Généraux', in Rights, Representation, and Reform: Nonsense on Stilts and Other Writings on the French Revolution, eds. P. Schofield, C. Pease-Watkin and C. Blamires (Oxford: Clarendon Press, 2002), 68.

60. Bentham, IPML, 69.

61. Bentham, IPML, 69-70 (emphasis added).

62. See Frederick Rosen, Jeremy Bentham and Representative Democracy: A Study of the Constitutional Code (Oxford: Clarendon Press, 1983), 200-20; Frederick Rosen, Classical Utilitarianism from Hume to Mill (London: Routledge, 2003), 221-6. 
63. UC, iii, 83, brouillon (initial sketch) for a work entitled 'National Prospects, or a Picture of Futurity'.

64. UC, iii, 83. Whether this statement constitutes renunciation of the direct calculation of pleasures and pains depends on the extent to which the language of subordinate ends is translatable into the language of sensation. If it is not so translatable, Bentham risks forfeiting the connection between moral discourse and real entities, which, for him, constitutes utilitarianism's signal advantage over competing theories.

65. See 'Principles of the Civil Code', Bowring, i, 301.

66. Compare John Rawls's inclusion of rights and liberties among social primary goods in A Theory of Justice (Oxford: Clarendon Press, 1972), 60-3, 92. For Ronald Dworkin, although only resources are distributable by his hypothetical insurance auction, an individual's internal capacities are included in his/her resources, and the equality of certain liberties is presupposed as a baseline condition ensuring the justice of the auction; see Sovereign Virtue: The Theory and Practice of Equality (Cambridge, Mass.: Harvard University Press, 2000), 146.

67. See Jeremy Bentham, 'Pannomial Fragments', in Jeremy Bentham: Selected Writings, ed. Stephen G. Engelmann (New Haven and London: Yale University Press, 2011), 267 (Bowring, iii, at 225).

68. 'Pannomial Fragments', 268 (Bowring, iii, 225).

69. See Martha C. Nussbaum, 'Nature, Function and Capability: Aristotle on Political Distribution', WIDER Working Papers (1986-2000) 1987/031 (Helsinki: UNU-WIDER, 1987), 1.

70. See Postema, 'Interests Universal and Particular', 130.

71. Bentham, 'Principles of the Civil Code', Bowring, i, 304.

72. Nussbaum, 'Nature, Function and Capability', 42.

73. Nussbaum, 'Nature, Function and Capability', 46.

74. Nussbaum, 'Human Functioning and Social Justice', 218, 222. For later iterations of the list, from which this capability is excluded, see Nussbaum, Sex and Social Justice, 41-2, Nussbaum, Frontiers of Justice, 76-8.

75. Nussbaum, 'Human Functioning and Social Justice', 214.

76. See Rawls, Theory of Justice, 397-8.

77. Rosen, Classical Utilitarianism, 234.

78. Bentham, 'Principles of the Civil Code', Bowring, i, 301.

79. Bentham, 'Place and Time', in Jeremy Bentham: Selected Writings, 204 (Bowring, i, 194).

80. See, for instance, Knud Haakonssen, The Science of a Legislator: The Natural Jurisprudence of David Hume and Adam Smith (Cambridge: Cambridge University Press, 1981), 83-4, 99-100; Donald Winch, 'Adam Smith: Scottish Moral Philosopher as Political Economist', Historical Journal 35 (1992): 109-10.

81. Bentham, 'Principles of the Civil Code', Bowring, i, 301-2.

82. See Rosen, Jeremy Bentham and Representative Democracy; Rosen, Classical Utilitarianism; Frederick Rosen, Thinking about Liberty (London: UCL, 1990); Paul Kelly, Utilitarianism and Distributive Justice: Jeremy Bentham and the Civil Law (Oxford: Oxford University Press, 1990); Allison Dube, The Theme of Acquisitiveness in Bentham's Political Thought (New York: Garland, 1991).

83. Sen, 'Well-Being, Agency and Freedom', 210.

84. See Rosen, Thinking about Liberty.

85. Sen, 'Well-Being, Agency and Freedom', 203.

86. Sen, 'Well-Being, Agency and Freedom', 186.

87. Sen, Idea of Justice, 297.

88. See Rosen, Classical Utilitarianism, 250.

89. See UC, $\mathrm{xx}, 180$, drafted for 'Supply without Burthen', comparing the 'inferior interests of extra-security for subsistence, opulence, and equality' with the 'superior interests of security, in comparison of which every other good is but a feather in the political scale'. See also Bentham, Writings on Political Economy: I, 242.

90. See, for instance, UC, xvii, 170, 'Method of an Institute of Political Economy' (Jeremy Bentham's Economic Writings, iii, 309).

91. See Writings on the Poor Laws: I, 10.

92. UC, iii, 83.

93. See 'Constitutional Code', Bowring, ix, 15.

94. See 'Pannomial Fragments', 275 (Bowring, iii, 229). For a fuller discussion, see Quinn, 'Jeremy Bentham, "The Psychology of Economic Man"', 13-17. The presence of subsistence among Bentham's subordinate ends indicates another overlap with the capability approach, 
concerning the importance of the 'basic capabilities' available at the bottom of a distribution: see Sen, 'Capability and Well-Being', 40-1. In Nussbaum's later lists of central human capabilities, the two first - life, and bodily health and integrity - map directly onto Bentham's subsistence (Sex and Social Justice, 41-2).

95. See Bentham, 'Manual of Political Economy', Writings on Political Economy: I, 189: 'Happiness - enjoyment - not money, is or ought to be the ultimate object of the legislator's care.'

96. 'Principles of the Civil Code', Bowring, i, 304.

97. See Postema, 'Interests Universal and Particular', 113.

98. Bentham himself does not stress this aspect of equality in his theory, and occasionally makes statements interpretable as limiting his understanding of 'equality of what' to resources, as, for instance, UC, iii, 83: 'equality: i.e. maximum opulence of the lower classes'.

99. Rosen, Classical Utilitarianism, 235.

100. Nussbaum, 'Human Functioning and Social Justice', 230. See also Sen, 'Equality of What?', 217; Sen, Idea of Justice, 283.

101. Nussbaum, Sex and Social Justice, 33.

102. Martha C. Nussbaum, 'Charles Taylor: Explanation and Practical Reason', in The Quality of Life, eds. M. C. Nussbaum and A. Sen (Oxford: Clarendon Press, 1994), 236 (emphasis added). See also Nussbaum, 'Human Functioning and Social Justice', 230.

103. See Jeremy Bentham, Writings on the Poor Laws: II, ed. M. Quinn (Oxford: Clarendon Press, 2010), 56-7, 648n, 666.

104. 'Principles of the Civil Code', Bowring, i, 309.

105. 'Principles of the Civil Code', Bowring, i, 344.

106. See Alkire, 'Why the Capability Approach?', 118-9; Robeyns, 'The Capability Approach in Practice', 362.

107. Bentham, 'Place and Time', 174 (Bowring, i, 181). Abstract utility was Bentham's shorthand for the balance of pleasures and pains derived from calculation on the basis of 'axioms of mental pathology', psychological propositions about human beings as such.

108. See Bentham, 'Place and Time', 170 (Bowring, i, 178).

109. See Michael Quinn, 'Popular Prejudices, Real Pains: What is the Legislator to Do when the People Err in Assigning Mischief?', in Bentham's Theory of Law and Public Opinion, eds. X. Zhai and M. Quinn (Cambridge: Cambridge University Press, 2014), 74-6.

110. See 'Memoirs and Correspondence', Bowring, $\mathrm{x}, 146-7$.

111. Bentham, 'Place and Time', 175 (Bowring, i, 182) (emphasis added).

112. UC, $\mathrm{xx}, 176$, drafted for 'Supply without Burthen'.

113. Bentham, IPML, 183 (emphasis added).

114. See Bentham, 'Place and Time', 174 (Bowring, i, 181-2).

115. UC, lxxii, 202.

116. Sen, 'Equality of What?', 219.

117. Sumner, 'Utility and Capability', 15.

118. See Sen, 'Human Rights and Capabilities', 160-3; Sen, Idea of Justice, 44-51.

119. See Sugden, 'What We Desire', 45-51; R. Layard, Happiness: Lessons from a New Science (London: Penguin, 2005), 113.

120. See Robeyns, 'The Capability Approach: A Theoretical Survey', 106.

121. See Jeremy Bentham, 'Constitutional Code Rationale', in First Principles Preparatory to Constitutional Code, ed. P. Schofield (Oxford: Clarendon Press, 1989), 232.

122. See Jeremy Bentham, Constitutional Code: I, eds. J. H. Burns and F. Rosen (Oxford: Clarendon Press, 1983).

123. See Sumner, 'Utility and Capability', 3.

124. It is, however, worth noting the role of security in facilitating a pluralistic context of choice wherein individuals are free to pursue any pleasure (and any conception of good) that does not clearly inflict harm by encroaching on the security of their fellows. I owe this point to Angela Marciniak.

125. Roger Crisp, 'Taking Stock of Utilitarianism', Utilitas 26 (2014): 245.

126. See Sen, Idea of Justice, 130, 404, 407.

127. Adam Smith, The Theory of Moral Sentiments, eds. D. D. Raphael and A. L. Macfie (Oxford: Oxford University Press, 1976), 210.

128. See Jeremy Bentham, Of Sexual Irregularities, and Other Writings on Sexual Morality, eds. P. Schofield, C. Pease-Watkin and M. Quinn (Oxford: Clarendon Press, 2014), 26-8, 98-100; Bentham, 'Not Paul, but Jesus, Vol. III', UC, clxi, 315-19. For a contemporary argument, 
see Helga Kuhse and Peter Singer, Should the Baby Live? The Problem of Handicapped Infants (Oxford: Oxford University Press, 1985).

129. P. Singer, Rethinking Life and Death: The Collapse of Our Traditional Ethics (Oxford: Oxford University Press, 1995), 130.

130. Sen, 'Well-Being, Agency and Freedom', 196.

131. Crisp, 'Taking Stock of Utilitarianism', 249.

\section{Bibliography}

Alkire, Sabina. 'Why the Capability Approach?', Journal of Human Development 6 (2005), 115-35. Bentham, Jeremy. The Book of Fallacies. Edited by P. Schofield. Oxford: Clarendon Press, 2015.

Bentham, Jeremy. A Comment on the Commentaries and A Fragment on Government. Edited by J. H. Burns and H. L. A. Hart. London: Athlone, 1977.

Bentham, Jeremy. Constitutional Code: I. Edited by J. H. Burns and F. Rosen. Oxford: Clarendon Press, 1983.

Bentham, Jeremy. Deontology, Together with A Table of the Springs of Action and Article on Utilitarianism. Edited by A. Goldworth. Oxford: Clarendon Press, 1983.

Bentham, Jeremy. First Principles Preparatory to Constitutional Code. Edited by P. Schofield. Oxford: Clarendon Press, 1989.

Bentham, Jeremy. An Introduction to the Principles of Morals and Legislation. Edited by J. H. Burns and H. L. A. Hart. Oxford: Clarendon Press, 1996.

Bentham, Jeremy. Jeremy Bentham's Economic Writings. Edited by W. Stark, 3 vols. London: Allen \& Unwin, 1952-4.

Bentham, Jeremy. Jeremy Bentham: Selected Writings. Edited by S. G. Engelmann. New Haven and London: Yale University Press, 2011.

Bentham, Jeremy. 'Not Paul, but Jesus: Vol. III. Doctrine'. Pre-publication version made available by the Bentham Project [2013]. http://discovery.ucl.ac.uk/1392179/3/npbj.pdf (accessed 19 March 2019)

Bentham, Jeremy. Of Sexual Irregularities, and Other Writings on Sexual Morality. Edited by P. Schofield, C. Pease-Watkin and M. Quinn. Oxford: Clarendon Press, 2014.

Bentham, Jeremy. Preparatory Principles. Edited by D. G. Long and P. Schofield. Oxford: Clarendon Press, 2016.

Bentham, Jeremy. Rationale of Judicial Evidence, Specially Applied to English Practice. Edited by J. S. Mill, 5 vols. London: Hunt \& Clarke, 1825.

Bentham, Jeremy. Rights, Representation, and Reform: Nonsense on Stilts and Other Writings on the French Revolution. Edited by P. Schofield, C. Pease-Watkin and C. Blamires. Oxford: Clarendon Press, 2002.

Bentham, Jeremy. Securities against Misrule and Other Writings for Tripoli and Greece. Edited by P. Schofield. Oxford: Clarendon Press, 1990.

Bentham, Jeremy. Supply without Burthen; or Escheat vice Taxation. London: J. Debrett, 1795.

Bentham, Jeremy. University College London collection of Bentham manuscripts [UC], boxes iclxxvi. Roman numerals refer to the box, Arabic to the folio.

Bentham, Jeremy. The Works of Jeremy Bentham, published under the Superintendence of his Executor, John Bowring, 11 vols. Edinburgh: William Tait, 1843.

Bentham, Jeremy. Writings on Political Economy: I. Edited by M. Quinn. Oxford: Clarendon Press, 2016.

Bentham, Jeremy. Writings on the Poor Laws: I. Edited by M. Quinn. Oxford: Clarendon Press, 2001.

Bentham, Jeremy. Writings on the Poor Laws: II. Edited by M. Quinn. Oxford: Clarendon Press, 2010.

Cohen, Gerald A. 'Equality of What? On Welfare, Goods, and Capabilities'. In The Quality of Life, edited by M. C. Nussbaum and A. Sen, 9-29. Oxford: Clarendon Press, 1994.

Crisp, Roger. 'Taking Stock of Utilitarianism', Utilitas 26 (2014): 231-49.

Deneulin, Séverine. 'Perfectionism, Paternalism and Liberalism in Sen and Nussbaum's Capability Approach', Review of Political Economy 14 (2002): 497-518.

Dube, Allison. The Theme of Acquisitiveness in Bentham's Political Thought. New York: Garland, 1991. 
Dworkin, Ronald. Sovereign Virtue: The Theory and Practice of Equality. Cambridge Mass.: Harvard University Press, 2000.

Guidi, Marco E. L. “'Shall the Blind Lead Those Who Can See?" Bentham's Theory of Political Economy'. In Perspectives on the History of Economic Thought Volume III, edited by D. E. Moggridge, 10-28. Aldershot: Edward Elgar, 1990.

Haakonssen, Knud. The Science of a Legislator: The Natural Jurisprudence of David Hume and Adam Smith. Cambridge: Cambridge University Press, 1981.

Kelly, Paul. Utilitarianism and Distributive Justice: Jeremy Bentham and the Civil Law. Oxford: Oxford University Press 1990.

Kuhse, Helga and Singer, Peter. Should the Baby Live? The Problem of Handicapped Infants. Oxford: Oxford University Press, 1985.

Layard, Richard. Happiness: Lessons from a New Science. London: Penguin, 2005.

Nussbaum, Martha C. 'Capabilities as Fundamental Entitlements: Sen and Social Justice', Feminist Economics 9 (2003): 33-59.

Nussbaum, Martha C. 'Charles Taylor: Explanation and Practical Reason'. In The Quality of Life, edited by M. C. Nussbaum and A. Sen, 232-41. Oxford: Clarendon Press, 1994.

Nussbaum, Martha C. Frontiers of Justice: Disability, Nationality, Species Membership. Cambridge, Mass.: Harvard University Press, 2006.

Nussbaum, Martha C. 'Human Functioning and Social Justice: In Defense of Aristotelian Essentialism', Political Theory 20 (1992): 202-46.

Nussbaum, Martha C. 'Nature, Function and Capability: Aristotle on Political Distribution'. WIDER Working Papers (1986-2000) 1987/031. Helsinki: UNU-WIDER, 1987.

Nussbaum, Martha C. Sex and Social Justice. New York: Oxford University Press, 1999.

Nussbaum, Martha C. Women and Human Development: The Capabilities Approach. Cambridge: Cambridge University Press, 2000.

Nussbaum, Martha C. and Sen, Amartya (eds.). The Quality of Life. Oxford: Clarendon Press, 1994.

Postema, Gerald J. 'Interests Universal and Particular: Bentham's Utilitarian Theory of Value', Utilitas 18 (2006): 109-33.

Qizilbash, Mozaffar. 'Amartya Sen's Capability View: Insightful Sketch or Distorted Picture?'. In The Capability Approach: Concepts, Measures and Applications, edited by F. Comin, M. Qizilbash and S. Alkire. Cambridge: Cambridge University Press, 2008.

Qizilbash, Mozaffar. 'Capability, Happiness and Adaptation in Sen and J. S. Mill', Utilitas 18 (2006): 20-32.

Quinn, Michael. 'Jeremy Bentham, “The Psychology of Economic Man”, and Behavioural Economics', CEconomia 6 (2016): 3-32.

Quinn, Michael. 'Popular Prejudices, Real Pains: What is the Legislator to Do when the People Err in Assigning Mischief?'. In Bentham's Theory of Law and Public Opinion, edited by X. Zhai and M. Quinn, 63-89. Cambridge: Cambridge University Press, 2014.

Rawls, John. A Theory of Justice. Oxford: Clarendon Press, 1972.

Riley, Jonathan. 'Liberal Rights in a Pareto-optimal Code', Utilitas 18 (2006): 61-79.

Robeyns, Ingrid. 'The Capability Approach: A Theoretical Survey', Journal of Human Development 6 (2005): 93-117.

Robeyns, Ingrid. 'The Capability Approach in Practice', Journal of Political Philosophy 14.3 (2006): 351-76.

Rosen, Frederick. Classical Utilitarianism from Hume to Mill. London: Routledge, 2003.

Rosen, Frederick. Jeremy Bentham and Representative Democracy: A Study of the Constitutional Code. Oxford: Clarendon Press, 1983.

Rosen, Frederick. Thinking about Liberty, London: UCL, 1990.

Ruggles, Thomas. The History of the Poor; Their Rights, Duties, and the Laws Respecting Them, 2 vols. London: J. Deighton, 1793-4.

Sen, Amartya. 'Capability and Well-Being'. In The Quality of Life, edited by M. Nussbaum and A. Sen, 30-52. Oxford: Clarendon Press, 1994.

Sen, Amartya. Commodities and Capabilities. New Delhi: Oxford University Press, 1999.

Sen, Amartya. 'Equality of What?'. In The Tanner Lectures on Human Values: I, 197-220. Cambridge: Cambridge University Press, 1980.

Sen, Amartya. 'Human Rights and Capabilities', Journal of Human Development 6 (2005): 151-66.

Sen, Amartya. The Idea of Justice. London: Penguin, 2009.

Sen, Amartya. 'Justice: Means versus Freedoms', Philosophy and Public Affairs 19 (1990): 111-21.

Sen, Amartya. Rationality and Freedom. Cambridge Mass.: Harvard University Press, 2002. 
Sen, Amartya. 'Reason, Freedom and Well-being', Utilitas 18 (2006): 81-96.

Sen, Amartya. 'Well-Being, Agency and Freedom', Journal of Philosophy 82 (1985): 169-221.

Singer, Peter. Rethinking Life and Death: The Collapse of Our Traditional Ethics. Oxford: Oxford University Press, 1995.

Smith, Adam. The Theory of Moral Sentiments. Edited by D. D. Raphael and A. L. Macfie. Oxford: Oxford University Press, 1976.

Stark, Werner. 'Jeremy Bentham as an Economist II. Bentham's Influence', Economic Journal 56 (1946): 583-608.

Sugden, Robert. "Welfare, Resources, and Capabilities: A Review of "Inequality Re-examined" by Amartya Sen', Journal of Economic Literature 31 (1993): 1947-62.

Sugden, Robert. 'What We Desire, What We Have Reason to Desire, Whatever We Might Desire: Mill and Sen on the Value of Opportunity', Utilitas 18 (2006): 33-51.

Sumner, Leonard W. 'Utility and Capability', Utilitas 18 (2006): 1-19.

Vallentyne, Peter. 'Capabilities versus Opportunities for Well-Being', Journal of Political Philosophy 13 (2005): 359-71.

Winch, Donald. 'Adam Smith: Scottish Moral Philosopher as Political Economist', Historical Journal 35 (1992): 91-113. 


\title{
8
}

\section{Jeremy Bentham and President Roosevelt's Four Freedoms}

\author{
Manuel Escamilla-Castillo
}

In this paper ${ }^{1}$ I want to examine and compare what seem, on the face of it at least, to be two very different doctrines: that enunciated by President Franklin D. Roosevelt in his State of the Union Address given in 1941; and that contained in Jeremy Bentham's discussion of natural rights in his Nonsense on Stilts, written in 1791 in response to the French Declaration of the Rights of Man (1789). Roosevelt's speech has come to be known as the Speech of the Four Freedoms. Despite the pressures of the times, it looked forward to the future and set out what it took to be the primary objectives of the new world order that would follow the successful ending of the Second World War. One outcome of the speech was the post-war concern to place human rights at the heart of the international order. Bentham's reflections were also responding to an event at the start of some 25 years of European (and often wider) warfare and they too looked to establish some fundamental principles for the nature of government in the eventual new order. Whereas Roosevelt emphasized freedom and rights, Bentham placed the emphasis on happiness and 'securities against misrule' and, rather than looking for the protection of rights and freedoms antecedent to government, saw the concern of government to pursue the secondary principles or subordinate ends of civil law - subsistence, abundance, equality and security - through which happiness would be attained. Nevertheless, as I shall argue, their two positions are actually closely related - not least in being influenced by the Founding Fathers' recognition of the centrality of the pursuit of 
happiness - and their comparison underlines the continuing relevance of Bentham's thought, and of his understanding of happiness, to discussions of the proper ends of government in the modern world.

On 6 January 1941, President Franklin D. Roosevelt fulfilled the constitutional requirement to deliver the State of the Union Address, a particularly solemn and significant moment in the political year. That speech came to be known as the Speech of the Four Freedoms. He began by referring to the international situation, a situation so extremely difficult that in his opinion he was justified in using the address to set forth the problems of the world and to identify solutions for them. The constitutional mandate for information refers to the problems of the United States, not to the problems of the world. But in 1941, faced with the efforts of many to adhere to the traditional isolationist position of the United States, ${ }^{2}$ he insisted that it was undeniable that the main problem of the Union was the world war currently being waged. For that reason, the speech was dedicated to the analysis of the international situation. Roosevelt was in a special position. The United States was preparing itself to assume the role of one of the great world powers, of which there would be only two by the end of the war. Roosevelt was aware of this, and aware also that it gave him enormous responsibility. It turned him into a world sovereign, a 'Legislator of the world', to use an established expression.

The Second World War (hereafter WWII) represents, in certain relevant respects, a continuation of the First World War (hereafter WWI). Of course, there were new major issues, of which the rise of totalitarianism was the most important. But, inasmuch as WWII was a continuation of WWI, with both wars seeking to solve national growth problems through imperial expansion, to that extent, Roosevelt recognized that WWII could be ended and peace achieved only with a new world order in which empires no longer existed.

This scenario of the historical redundancy of a dominant political model was not new to Roosevelt. On a national scale and, of course, without the bloodthirsty inhumanity of WWI, the Great Depression that began in 1929 also required a search for new models of social and economic organization. The New Deal was Roosevelt's response to that national and world anguish. It does not matter now whether the response was right or not in terms of economic efficiency or effectiveness of rights and freedoms. ${ }^{3}$ What remains important, for the purposes of this paper, is the consistency of New Deal policy with the proposals set out in the Four Freedoms Speech. That speech was Roosevelt's response to a world that had reached, with WWII, a maximum degree of the disruption that had been anticipated by the Great Depression: 'In the future days which 
we seek to make sure, we look forward to a world founded upon four essential human freedoms.' ${ }^{4}$

'The first [of the Four Freedoms] is freedom of speech and expression [...]'. ${ }^{5}$ For Roosevelt, a modern political order could no longer be established on any basis other than the freedom of the person to form independently an image of the world and to publicly express that image. Many fundamental questions are involved here: the sovereignty of the individual conscience, the appeal to the opinion of the enlightened public, a commitment to the pursuit and development of objective truth and to the expression of views that lies at the heart of democracy itself, and so on. That freedom, as against the idea of mere tolerance that preceded it, builds a deeper commitment, indeed a transcendent foundation, into the very core of the new world view: ' $[\mathrm{t}]$ he Second is freedom of every person to worship God in his own way [...]'. ${ }^{6}$ These first two freedoms are considered as encompassing the content of the First Amendment of the United States Constitution: 'Congress shall make no law respecting an establishment of religion, or prohibiting the free exercise thereof; or abridging the freedom of speech, or of the press; or the right of the people peaceably to assemble, and to petition the Government for a redress of grievances.'

Apart from the greater breadth of the First Amendment, a further difference between it and Roosevelt's text is that it speaks of 'freedoms': that is to say, recourse is had to the concept of freedoms of the English tradition, as Edmund Burke theorized. ${ }^{7}$ Old English liberties, according to Burke, are something that we detect a posteriori in the evolution of laws and political institutions, and not as a priori fundamentals of the political order. Burke notes that:

Government is not made in virtue of natural rights, which may and do exist in total independence of it; and exist in much greater clearness, and in a much greater degree of abstract perfection: but their abstract perfection is their practical defect. By having a right to every thing they want every thing. Government is a contrivance of human wisdom to provide for human wants. Men have a right that these wants should be provided for by this wisdom. ${ }^{8}$

Another important difference between the approach of the Speech and that of the First Amendment is that the Constitution sets out the limits of the government in its different branches ('Congress shall make no law ... '); it does not enumerate the rights that define the government. The difference between the points of view in these two texts is remarkable. The Speech lists freedoms that were to structure the world political 
order; the First Amendment, on the other hand, supplementing the Constitution, specifies restrictions on government action. In fact, the Constitution of the United States, in essence, is a list of the tasks that can be undertaken in the country's governance. The idea behind this approach was very popular at the time of the adoption of the Constitution and featured heavily in the debate between supporters of and opponents to the inclusion of a Bill of Rights in it. Those who proposed excluding a statement of rights thought that making a list of rights meant limiting them; for them, citizens have all the rights, not only those that a list would contain even at its widest. Government, on the other hand, in all its branches, would have only those possibilities of action expressly authorized by the Constitution, as exceptions to the general principle of omnicompetence of citizens. ${ }^{9}$

Despite these differences, President Roosevelt's first two freedoms expressed the essential content of the First Amendment by insisting that a central part of the idea of freedom, perhaps the most important part, is religious freedom and freedom of expression. The other two freedoms he lists present a different set of problems. They are freedom from fear and freedom from want. From the theoretical point of view, the main difficulty of these two freedoms is precisely that their definition as liberties clearly exceeds the traditional negative definition of freedom, which characterizes it as an absence of coercion and situates it in the relational sphere: I am free as long as no one else hinders my capacity for action. It is important to clarify whether President Roosevelt's Four Freedoms really refer to freedom or if Roosevelt was using the prestige and the popular acceptance of the word 'freedom' to introduce political objectives other than freedom - or perhaps even contrary to it. This would be the case if the use of the word 'freedom' by Roosevelt in 'freedom from fear' and 'freedom from want' could be said to be what have been called the rhetorical (or poetic) uses of freedom - usage that links freedom, which is a moral notion, to the physical realm. It is a use of the term that is connected with the idea, which Isaiah Berlin subsequently developed, of 'positive liberty'. According to this idea, the achievement of freedom depends not just on others not acting to restrain human behaviour (negative liberty), but requires that they contribute with their own actions to the personal achievements of those who claim freedom. Proponents of negative liberty hold that many of the confusions of political theory in relation to freedom derive from this essentially improper use of language. In fact, it is a matter of introducing the idea of freedom into the field of an antonym, necessity, to which Edmund Burke refers in the passage quoted above. Thus, if Roosevelt's last two freedoms are to be 
understood in terms of Berlin's notion of positive freedom, we would have to conclude that the president had introduced himself into a land very different from that of freedom. This is most clearly so in the case of freedom from want, since this refers to the satisfaction of basic needs. In the case of freedom from fear, the question is more complex, as we shall see in relation to Bentham's theory.

Another interpretation might be to understand these last two freedoms in terms of the capabilities approach of Amartya Sen. Effectively, Sen develops another sense of freedom, building on what John Rawls calls 'primary goods', by speaking of freedom as capacity. This refines the concept of positive freedom: 'Capability is, thus, a set of vectors of functioning, reflecting the person's freedom to lead one type of life or another. ${ }^{10}$ Sen thus places himself within the limits of the concept of freedom. He himself admits as much by including his discussion of freedom as a capacity within a work dedicated to the discussion on equality. Moreover, Sen explicitly refers to the second pair of freedoms identified by Roosevelt: 'Freedom from want, which, translated into world terms, means economic understandings which will secure to every nation a healthy peacetime life for its inhabitants'; ${ }^{11}$ freedom from fear, 'which, translated into world terms, means a world-wide reduction of armaments to such a point and in such a thorough fashion that no nation will be in a position to commit an act of physical aggression against any neighbor. ${ }^{12}$ If these two freedoms are understood, as Sen proposes, as distinct dimensions of freedom, then Roosevelt's proposal would be coherent and could not be interpreted as an attempt to introduce political objectives unrelated to the logic of rights under the pretext of defending freedom.

Understanding freedom as a capability allows us to redirect the idea of positive freedom in a way that is not contrary to that of negative freedom. This means that when Roosevelt speaks of Four Freedoms, he is not making a mistake (as would be the case if we accepted that his last two freedoms leave the real sphere of freedom to enter into that of necessity), but he continues to talk about freedom in its proper sense. Moreover, understanding freedom as capability allows us not to be confined to the merely negative aspect of freedom, while avoiding the self-contradiction that occurs when freedom is extended to include necessity. Sen seeks to escape from the old opposition between formal and material freedom by claiming the material bases that he considers indispensable for the deployment of capabilities as components of freedom. In conclusion, if Sen's proposal is accepted, we should conclude that Roosevelt was talking all the time just about freedom, not about freedom and necessity. 
Roosevelt's explanations of these last two freedoms can be summed up in the value and purpose of a healthy peace, in the case of freedom from want, and in a peace in its original sense of the absence of war, in freedom from fear. The Address is thus situated on a clearly rhetorical ground, which was necessitated by the two major crises facing the presidency of Roosevelt, the Great Depression and WWII. Sen states:

[This] language is not aberrant here. It fits into a broad general concept of freedom, rather than having to be seen as invoking some peculiarly remote idea of freedom.

That is, Roosevelt is talking about freedom:

Freedom as a value demands that certain things be considered seriously for that reason (whether or not it is valued for any other reason as well). The notion of freedom as effective power to achieve what one would choose is an important part of the general idea of freedom. ${ }^{13}$

There is a third way of understanding freedom that is different from the two we have just considered, negative freedom and positive freedom. We can find this in Wilhelm von Humboldt's theory, especially in The Sphere and Duties of Government, which conceptualizes modern freedom as a manifestation and, at the same time, an expression of individuality, which means that freedom must lead to diversity and to variety in its forms. ${ }^{14}$ That diversity is positive. Nothing is more beautiful than the multiplicity of existence produced by the joint action of freedom and individuality. The multiplicity of existence constitutes the fullness of the human being, which is the person's vocation. It is the enthusiastic exaltation of individual freedom characteristic of romanticism, which Humboldt already anticipates:

The true end of Man (...), is the highest and most harmonious development of his powers to a complete and consistent whole. Freedom is the grand and indispensable condition which the possibility of such a development presupposes; but there is besides another essential, - intimately connected with freedom, it is true a variety of situations. Even the most free and self-reliant of men is thwarted and hindered in his development by uniformity of position. But as it is evident, on the one hand, that such a diversity is a constant result of freedom, and on the other, that there is a species 
of oppression which, without imposing restrictions on man himself, gives a peculiar impress of its own to surrounding circumstances; these two conditions, of freedom and variety of situation, may be regarded, in a certain sense, as one and the same. ${ }^{15}$

One might think that this development of the powers of the human being to which Humboldt refers is an idea close to the capacities of which Amartya Sen speaks. But there is a very notable difference - in Humboldt's insistence that the development of human power is possible only on the condition that state intervention in this field is reduced as much as possible. For Humboldt, state intervention could take place only at the expense of a huge, uniform impoverishment of the human:

(...) whatever kind of obstacles the state proposes to remove - in the name of social justice and equality of opportunity - intervention would always be unacceptable because, far from creating better conditions so that all individuals can make use of their freedom of choice, such a state in fact lowers for everybody the possibilities of a self-chosen, self-created life (...).

The dominant reason why the state is not to be entrusted with the task of creating conditions of fairness for all, is a strong dislike of all attempts to put general principles into practice by political and administrative means. And this aversion is characteristic of a liberal disposition for which diversity is the corollary of individual liberty. ${ }^{16}$

According to Humboldt's approach, then, freedom is the starting point of modern society, because it is integral to the very existence of the individual human subject, and is also the sine qua non requirement for the full development of human possibilities and potential, and that will lead to the multiplicity of human ways of living, in the same way that the free expansion of life has led to the variety of plant and animal species. Variety is wealth; uniformity is impoverishment. Public action, being unavoidably uniform, frustrates the humanizing action of freedom. The versions of freedom proposed by Berlin and Sen, while plausible, provide a slide of meaning towards a version of freedom that calls for state intervention, with coercive action that enforces social cooperation, instead of letting this cooperation be produced spontaneously, through voluntary agreements.

Humboldt returns us to the original meaning of freedom and allows us to understand why the freedom of religious beliefs and the manifestation of those beliefs through worship is valuable. Freedom is valuable 
because it allows variety. Variety, in turn, is valuable because it is the only way to approach the truth, a truth that will show itself in that variety or, at least, that will separate us from error. Berlin and Sen's proposals on freedom, by broadening their scope, permit Roosevelt's Four Freedoms to be considered homogeneous. But they are not. To the extent that the first two freedoms of President Roosevelt do not rely on state intervention to produce the freedom of individuals, they are also a coherent expression of Humboldt's vision of freedom as a condition and incentive of individual self-development. ${ }^{17}$ Something different, however, happens with the last two freedoms of President Roosevelt, who thinks of them as correct expressions of freedom.

Roosevelt, faced with the two serious crises that shaped his mandate, was trying to find a way towards the establishment of a lasting world order. He speaks of the fact that these freedoms constitute human rights ('Freedom means the supremacy of human rights everywhere') and he insists every time that the Four Freedoms are explained that they were to be in force 'anywhere in the world'. ${ }^{18}$ Certainly, this recurring expression seeks a rhetorical effect, but it also affirms that isolationism was no longer possible in the world.

The durability and universality of the Four Freedoms became apparent when, in his State of the Union Address of 11 January 1944, Roosevelt announced a Second Bill of Rights. ${ }^{19}$ According to the president, the Bill of Rights had dealt only with 'political rights', which guaranteed life and liberty, but the text of the Declaration of Independence, passed in 1776, further stated that the purpose of governments (which was the only thing that would keep them in power against the right of the people to change or abolish them otherwise) was the guarantee of these rights to life and freedom, and also to one more thing:

We hold these truths to be self-evident, that all men are created equal, that they are endowed by their Creator with certain unalienable Rights, that among these are Life, Liberty and the Pursuit of Happiness.

The history of happiness as a political objective goes back to the Platonic (or Socratic) concept of eudaemonia, and already in Aristotle this is presented not only as linked to the inner world (virtue and wisdom), but also to the possession of goods, whether immaterial (friendship) or material (wealth). In the context of the Declaration of Independence, the immediate antecedents of this idea are those natural rights enumerated by John Locke: life, liberty and goods. The pursuit of happiness would 
replace property in the Lockean trio. All of this enables the notion of the 'pursuit of happiness' to be included (it is not a right to happiness, which would be something more definite). Moreover, that objective gives a material basis for the ends of government, as President Roosevelt does when he concretizes the objectives that the government must guarantee for the fulfilment of its duty to allow the pursuit of happiness in useful and remunerated work; a sufficient profit, also in the case of farmers; a free market, without unfair competition or monopolies; decent housing; the right to medical assistance and health; adequate social security, and good education..$^{20}$

The foundation for the rights set out in the Second Bill of Rights proposed in Roosevelt's 1944 speech is that the pursuit of happiness must be equal. And the scriptural authority for that can be found in the Declaration of Independence, which insisted that 'all men are created equal', and claimed the right to life, liberty and 'the right to "Pursuit of Happiness"'.

By 1944, the United States was already fully involved in the two great arenas of WWII, the Euro-African and the Pacific, and it represented the only world leadership that could rival the Soviet Union. This global role was to be strengthened through India being granted independence from the British Empire and the subsequent decolonization, first in the Muslim countries of North Africa and the Middle East, and later in the rest of Africa and Asia. With the Four Freedoms Speech and the subsequent Atlantic Charter, in which Roosevelt and British premier Winston Churchill agreed that the principles set out there would be the foundation of post-war world order, the Second Bill of Rights was also destined to have a planetary reach.

F. D. Roosevelt did not live to see the promised land of victory over the Axis, but his objectives for world peace were embodied in a series of institutions and norms, such as the institution of the United Nations, and the Universal Declaration of Human Rights (hereafter UDHR). The draft of this Declaration, which was approved by United Nations General Assembly Resolution 217 A (III) on 10 December 1948, was written by an international committee in which the French René Cassin and American Eleanor Roosevelt, widow of the president, played a leading role. ${ }^{21}$ They ensured that the formal and material features of the Universal Declaration would reflect the rights contained in the Declaration of Independence, the Constitution and the Bill of Rights, as well as in the French model of the Declaration of Rights of Man and the Citizen. Two further decisive components were the Four Freedoms and the consequent proposal of a Second Bill of Rights. Thus, while articles 1 to 21 
of UDHR develop the content of the First Bill of Rights, those from 22 to 29 do so with the second. In this way, the Preamble to the Universal Declaration proclaims the aspiration to 'the advent of a world in which human beings shall enjoy freedom of speech and belief and freedom from fear and want'. ${ }^{22}$ The influence of this vision of two Bills of Rights would then be transferred to the two Covenants approved by the United Nations in 1966, the International Covenant on Civil and Political Rights (ICCPR) and the International Covenant on Economic, Social and Cultural Rights (ICESCR). The Preamble to the ICESCR states: 'Recognizing that, in accordance with the Universal Declaration of Human Rights, the ideal of free human beings enjoying freedom from fear and want can only be achieved if conditions are created whereby everyone may enjoy his economic, social and cultural rights, as well as his civil and political rights'. ${ }^{23}$ The whole development of human rights, both at the level of international treaties and that of the constitutions of democratic countries, has subsequently followed this dual structure.

The traditional interpretation of this dual structure of human rights sees it as a reflection of the partition of the world after WWII into a Western and a communist bloc. But we may also understand the international development of human rights following WWII as intended to consolidate the social-democratic political-economic model as a distinctive product of American liberalism, though on the basis of other previous theoretical and practical developments. ${ }^{24}$ F. A. Hayek was already able to argue in The Road to Serfdom, written in the Cambridge exile of the London School of Economics during WWII, that the rule of social-democracy was undisputed in Western political practice, dedicating his book 'To the socialists of all parties'. ${ }^{25}$

\section{II}

One of the hallmarks of Jeremy Bentham's theory was his hostility to the notion of natural rights, which is what human rights were called in his time. He was against not only the idea itself, but equally the practical application that was made of it in the two great revolutionary moments of the eighteenth century, the American and the French revolutions. The basis of Bentham's hostility to the idea of natural rights was that they are grounded on a 'fantastic' or 'capricious' principle, the principle of sympathy and antipathy, which is the principle most opposed to utilitarianism. ${ }^{26}$ The two other reasons why Bentham thought natural rights unacceptable were that they are 'anarchical fallacies' and 'nonsense upon 
stilts'. ${ }^{27}$ They are anarchical fallacies because they are lies elaborated for the purpose of deceiving; where that deceit produces, in addition, an anarchic effect. They are lies because, for Bentham, they only become rights when they are embodied in law. ${ }^{28}$ 'Natural' rights, i.e. rights that would exist in nature, outside the law or before it, could not be such rights; hence the lie. Such lies as natural rights engender anarchy in society by seeming to make the validity of legal rules dependent on their conformity with these prior propositions. In extreme positions, as with the American and French revolutions, they can lead to the overthrow of government and to civil war. They are 'nonsense upon stilts' because they are fictional entities that are placed on a pedestal, so that everyone looks at them in amazement without wondering if there is any solid underpinning: 'Natural rights is simple nonsense: natural and imprescriptible rights, rhetorical nonsense, nonsense upon stilts. ${ }^{29}$ Bentham's criticism of the idea of natural rights marks the beginning of their decline in the field of law and politics. During the rest of the nineteenth century and the first half of the twentieth century, the idea of natural rights disappears from political and legal theory and practice until they were revived, under the name of 'human rights', in the Universal Declaration of $1948 .{ }^{30}$

When Bentham developed his constitutional theory, in the Constitutional Code, he proposed replacing 'natural rights' with the expression 'securities against misrule', guarantees against bad government. ${ }^{31}$ If we were to apply Bentham's proposals to the Four Freedoms, they would be considered not, as President Roosevelt saw them, as a prior matter in respect of legislative action, but rather as the telos or consequence of that action. They would be a device implemented in the laws, and a result directed to prevent rulers from abusing their power by betraying the interests of the governed, interests that would be indirectly confirmed and protected by the content of those guarantees. Legislation would concern itself not with antecedent liberties or rights, which rulers must approve or that policies should promote, but with setting responsibilities, and imposing penalties in their case; and this, expost facto, which is the normal way in which the law acts, as an instrument of political action that is orientated to freedom. From another point of view, using the concept of securities instead of the concept of freedoms, we have an indisputable concrete reference, rather than appealing to metaphysical notions (nature, reason), or to historical conceptions of metaphysical notions (nature of things), or to other contentious notions. Written, fixed and empirically verifiable texts are the sole basis for people's claims. In fact, over time, Bentham relaxed the initial rigidity of his stance and admitted the usefulness of a solemn political statement of objectives, 
although he continued to insist that this should be expressed in guarantees rather than by rights. On the occasion of his attempt to promulgate the Constitution he had drafted for Tripoli, he even proposed that the Pasha address the people by stating that the Prophet Muhammad had in an apparition ordered him to carry out his political reforms. ${ }^{32}$

Bentham's critique of natural rights was central to his theory, but to capture the difference between Bentham's and Roosevelt's proposals, it is more useful to focus on the development by the former of what he called secondary principles, or the subordinate ends of the civil law. As we have seen, Bentham's political-legal proposal is based not on principles or rights but on ends or teleology. The ruler is not to guarantee rights, but to achieve certain goals. We are thus brought into the field of what Burke had called 'needs'. The justification of the institution of the government of some people over others is, from this point of view, that it is necessary to satisfy human needs. For Bentham, the ruler and the law (which is the instrument and at the same time the creator of the ruler), if they are to be as they should be, must satisfy the needs of citizens (or subjects, as the case may be), enabling them to achieve happiness. Taking into account the variety of human aspirations, one must understand 'happiness' in an abstract, broad sense. For that very reason, the Declaration of Independence does not speak of the attainment of happiness, but of the pursuit of happiness. The question, then, is of what the ruler should do for the happiness of citizens.

For Bentham, he must act by means of law: by means of criminal law, to prevent or reduce violations of citizens' rights; by civil law, so that citizens get the goods to which they aspire (satisfy their needs). The main purpose of civil law, in this way, is happiness. The guide to happiness is found in the four secondary ends: subsistence, abundance, equality, security. ${ }^{33}$

Bentham's secondary principles are set out in this way because, according to him, that is the logical order. The first duty of a government is to assure the existence of the essential goods for the life of the people, for one can hardly be happy without the very means of mere subsistence: food, shelter, clothing, etc. People are happier if they are not limited to having just what is strictly necessary, but instead have such goods in abundance and variety. By applying the principle of decreasing marginal utility, an optimal level of happiness is achieved, once the abundance of material goods is obtained, provided that these goods are distributed in conditions of equality among the population. Finally, when all this was achieved, Bentham thought that people would be happier if they could possess and dispose of all of those goods with security. 
Although that is the logical order of secondary principles, according to Bentham, he thinks that it is necessary to take into account - for the ordering of these principles, in addition to logical-formal considerations - other factors of a pragmatic nature: mainly, what the ruler should do to achieve those ends. The collection and supply of the necessary goods to ensure the subsistence of the population (not to mention abundance) depends on the effort of the people in their production. Only by striving as much as possible to assure people of the enjoyment of the product of their efforts is there a way to obtain what is necessary and convenient for life. The Hobbesian background of Bentham's theory arises powerfully in this theme.

For Bentham, freedom and security are deeply and reciprocally involved. You are free only to the extent that the fear of being extorted by anyone stronger than you is absent. Where there is no security, there is no freedom, only the law of the strongest. Even a tyrant is preferable to misrule. In a situation of anarchy, everybody is subjected to a maximal despotism, more fearsome than any tyranny. In fact, government is necessarily exercised by restricting freedom. To speak of 'freedom' as the end of government is to use misleading language. It is better to make clear that the end of government and law is security, rather than freedom. Freedom for Bentham is nothing more than a 'branch' of security, a goal subordinated to it.

Security acts both in the political sphere, in a broad sense, by the elimination of violence, and also in the specifically legal meaning of the guaranty of expectations. Bentham talks of the frustration of expectations as a great evil that would subtract from any act all the good that is expected from it. Moreover, a frustrated rational expectation would mean not only the loss of the expected good but would bring the added harm of a frustrated hope. He speaks in this sense of the 'disappointment-preventing principle'. In legal theory, this set of considerations traditionally receives the denomination of 'legal certainty'. In Bentham's theory, it is the second great set of reasons that supports the thesis of the understanding of freedom as well-understood security.

It should be remembered that this security encompassing freedom occupies the last place in Bentham's logical ordering of what he calls secondary principles to the primary principle of the greatest happiness. It is Bentham himself who clarifies that, if pragmatic considerations were taken into account, this order of priority must be altered so as to obtain the end of the greatest happiness. Without security, the production of goods in such a quantity as to ensure subsistence could not be expected, let alone abundance, thus security becomes the first of the secondary principles: 
Security was associated with having enough subsistence for the present and future and was even associated with equality in so far as a more equal society was also more likely to respect the rules of property and protect individuals from harm. But security was particularly related to law and to that law that protected the individual's person and property from attack by others and by government itself. The enforcement of the law via the courts achieved the former and a system of representative democracy (based on the secret ballot, frequent elections, and numerous checks on the abuse of power) provided security against the latter. ${ }^{34}$

The other secondary principles - subsistence, abundance and equality should be considered exactly in this order and insofar as they do not interfere with the achievement of security; otherwise, inconsistency would be the result: subsistence or equality must be obtained without sacrificing security, because this is the unique basis of them. In any event, in no circumstances should these secondary purposes be understood as rights other than legal rights; not even as moral rights:

But why did Bentham still deny from this perspective that a moral right to security could exist? He did so because society cannot reconcile disparate claims to various rights from the point of view of the individual. The whole point of the utility principle is to provide an external standard with which individual claims can be reconciled. Absolute claims to rights prevent this very reconciliation. ${ }^{35}$

\section{III}

Few things might seem so opposed as President Roosevelt's Four Freedoms and Bentham's secondary principles. But, after careful consideration, there are numerous coincidences that must be emphasized. The starting point in both is a reflection on the reciprocal entailment of freedom and security. In the case of Bentham, general, indeterminate freedom is a branch of security; in that of Roosevelt, the essential freedom is freedom of religion and freedom of expression, corresponding with the American tradition. Bentham and Roosevelt both warn that equality in the pursuit of happiness could not be guaranteed even if, as Tocqueville pointed out, equality is a central value in democratic society. ${ }^{36} \mathrm{As}$ a means to happiness (perhaps as happiness itself), Roosevelt's 'freedom' from fear and necessity and Bentham's security that allows subsistence 
and abundance are essentially the same. Finally, both are trying to define the lines of action to be followed by rulers around the world.

Talking now of differences, we must point out the conceptual and logical rigour of Bentham contrasted with the imprecision and rhetoric of Roosevelt's use of the term 'freedoms', as already mentioned, which makes it difficult to know precisely where he is situated and the consequences of achieving or failing the objectives. Are these rights moral, political or legal? Above all, are the Four Freedoms principles or starting points for political action where non-compliance would cancel the legitimacy of the process? In the case of Bentham's principles, in spite of the name, these are aims and objectives that must be calculated by the effectiveness of the measures adopted, without leaving sharp disqualifications except in extreme cases. It is an appeal to rationality, to complex analysis, to pondering. In the case of the Four Freedoms, the speech is strict, without chiaroscuro. It is true that the times of the Great Depression and, later, of WWII, were enormously difficult. But the times in which Jeremy Bentham lived were also not easy, although there was a clear horizon and confidence in progress. Still, in 1944, or in 1948, when the UDHR was approved, the future was uncertain.

The great difference between the two interventions is undoubtedly the recipe to remedy the shortcomings and to meet people's needs. The remedy is wealth, of course. The question is where that wealth comes from and how it can be increased and made more available. For Roosevelt, and the social-democratic tendency he advocated, there were two major phases about wealth to take into account, phases that are mutually independent: their production and distribution. Both require governing decisions on the part of authority. And that is what Roosevelt did; he established a centralized political direction of the economy, of production and of distribution of wealth. It seemed to be the best idea at a time of serious crisis. But it was an emergency solution, which soon ran out. The formula that was put to work to reverse the Great Depression was running low when the even more serious crisis of war fuelled a new start-up of the productive energies of the United States and also of many countries not directly involved in the conflict. Before this last answer to the crisis was exhausted, the peace model was advocated, although it would reveal itself as a precarious peace.

For peace, Bentham's proposal seems to be better adapted: if we think that everyone is the best judge of his/her own interests and that the production of wealth is not watertight with respect to distribution, then freedom and security mark the secure path to wealth and to the remedy for necessity. 
In the post-WWII world, we have been encumbered with a political rhetoric about rights and freedom that is rarely capable of addressing the ordering of priorities and the distribution of aid and support in regions less wealthy than the West. But in thinking about those priorities, and in taking seriously the obstacles that exist to the realization of happiness in the world, we might find Bentham a more useful tool, even if we fly under the flag of the rhetoric of human rights formulated as ambiguously as Roosevelt did.

\section{Notes}

1. I am grateful for the comments and suggestions of the attendees at the Symposium on Happiness in Political and Moral Thought, organized by Professor Georgios Varouxakis at UCL, in October 2017; especially those of Professor Ellen Kennedy, of the University of Pennsylvania, who also told me about Ursula Vogel's article, which I will quote later. As always, I have discussed this paper with Professor Jiménez-Sánchez, from the University of Granada. Finally, I have included all the many accurate corrections made by Professor Mark Philp, from Warwick University, for whose efforts I am sincerely grateful.

2. In a certain sense, we can say that the United States is constitutively isolationist inasmuch as the colonizing mentality of the Pilgrim Fathers was based on the vision of a land of unlimited promise, for the always possible expansion that allowed the conquest of the West. Subsequently, the Monroe Doctrine (1823) extended the possible limits of the United States to continental scale. Finally, the Hawley-Smoot Tariff Act (19 U.S.C., 4, 1930) legislatively set commercial isolationism against the rest of the world.

3. In fact, the New Deal left practically no trace in the Constitution of the United States itself Akhil R. Amar, America's Constitution. A Biography (New York: Random House, 2006), 475: 'The only textual amendment to be ratified under Franklin Delano Roosevelt was the Twenty-first, repealing Prohibition' (628, n. 8).

4. Franklin D. Roosevelt, 'Message to Congress - The State of the Union' (speech file 1353A), 6 January 1941, in Master Speech File, 1898-1945, Franklin D. Roosevelt, Box 58, Franklin, in Franklin Delano Roosevelt Library and Museum, 20. http://www.fdrlibrary.marist.edu/archives/collections/franklin/index.php? $\mathrm{p}=$ collections/findingaid\&id $=582$ (accessed 14.06.2018).

5. Roosevelt, 'Message to Congress', 20.

6. Roosevelt, 'Message to Congress', 20.

7. Roosevelt, 'Message to Congress', 20.

8. Edmund Burke, Reflections on the Revolution in France, in Select Works of Edmund Burke, a new imprint of the Payne Edition, foreword and biographical note by Francis Canavan (Indianapolis: Liberty Fund, 1999), Vol. 2, 152.

9. A. Hamilton, J. Madison and J. Jay, The Federalist, in The Federalist, with Letters of 'Brutus', ed. T. Ball, Cambridge Texts in the History of Political Thought (Cambridge: Cambridge University Press, 2003), No. 85.

10. Amartya Sen, Inequality Reexamined (Oxford: Clarendon Press, 1992), 40.

11. Roosevelt, 'Message to Congress', 21.

12. Roosevelt, 'Message to Congress', 21.

13. Sen, Inequality Reexamined, 68-9.

14. Wilhelm von Humboldt, The Sphere and Duties of Government, trans. J. Coulthard (London: John Chapman, 1854). http://oll.libertyfund.org/titles/589\#lf0053_head_002 (accessed 15.06.2018).

15. Humboldt, Sphere and Duties of Government, 11.

16. Ursula Vogel, 'Liberty Is Beautiful: Von Humboldt's Gift to Liberalism', History of Political Thought, III/1 (1982): 99.

17. Vogel, 'Liberty Is Beautiful', 81.

18. Roosevelt, 'Message to Congress', 21. 
19. Roger Daniels, Franklin D. Roosevelt: The War Years, 1939-1945 (Urbana, Chicago and Springfield: University of Illinois Press, 2016), 439ff.

20. Franklin D. Roosevelt, 'Radio Address to the Nation - Quoting State of the Union' (speech file 1502), 11 January 1944, in Master Speech File, 1898-1945, Franklin D. Roosevelt, Box 77, Franklin, in Franklin Delano Roosevelt Library and Museum, 19-20. http://www.fdrlibrary. marist.edu/_resources/images/msf/msfb0131 (accessed 17.06.2018).

21. M. G. Johnson, 'Internationalization of Human Rights', in The Eleanor Roosevelt Encyclopedia, eds. Maurine H. Beasley, Holly C. Shulman and Henry R. Beasley (Westport and London: Greenwood Press, 2000), 256-60.

22. United Nations, Universal Declaration of Human Rights, 1948. http://www.un.org/en/universal-declaration-human-rights/ (accessed 16.6.2018).

23. ICESCR, International Covenant on Economic, Social and Cultural Rights, 1966. https://www. un.org/ruleoflaw/files/International $\% 20$ Covenant $\% 20$ on $\% 20$ Economic, $\% 20$ Social $\% 20$ and\%20Cultural\%20Rights.pdf (accessed 23.09.2018).

24. 'Surviving for a generation, too, was the political order fashioned by Franklin Roosevelt. The New Deal itself, as a series of economic and social reform measures, lasted only from 1933 to 1938. But the larger New Deal system of politics lasted until at least until the late 1960s. Through those years the Democratic party was the majority party, and it broadly identified itself with a liberal agenda, if liberalism is defined in its modern sense as a faith in the benign capacity of government, an acceptance of a mixed economy, sympathy for a modest welfare state, and some sensitivity to labour and ethnic constituencies.' Michael J. Heale, Franklin D. Roosevelt: The New Deal and War (London \& New York: Routledge, 1999), 77.

25. Friedrich A. Hayek, The Road to Serfdom, in The Collected Works, Vol. 2 (Chicago: University of Chicago Press, 2007), 7.

26. Frederick Rosen, 'Individual Sacrifice and the Greatest Happiness: Bentham on Utility and Rights', Utilitas 10/2 (1998): 132 and n. 10.

27. Manuel Escamilla-Castillo, Bentham (Barcelona: RBA, 2017), 93-117.

28. Jeremy Bentham, Nonsense upon Stilts, or Pandora's Box Opened, or the French Declaration of Rights Prefixed to the Constitution of 1791 Laid Open and Exposed - with a Comparative Sketch of What Has Been Done on the Same Subject in the Constitution of 1795, and a Sample of Citizen Sieyès, in Rights, Representation and Reform. Nonsense upon Stilts and Other Writings on the French Revolution, The Collected Works of Jeremy Bentham, eds. Philip Schofield, Catherine Pease-Watkin and Cyprian Blamires (Oxford: Clarendon Press, 2002), 229.

29. Bentham, Nonsense upon Stilts, 330.

30. William A. Edmundson, An Introduction to Rights (Cambridge: Cambridge University Press, 2004), 105ff.

31. John R. Dinwiddy, 'Bentham', in Bentham. Selected Writings by John Dinwiddy, ed. William L. Twining (Stanford: Stanford University Press, 2005), 71ff.

32. Philip Schofield, Utility and Democracy. The Political Thought of Jeremy Bentham (Oxford: Oxford University Press, 2006), 72.

33. Jeremy Bentham, Principles of the Civil Code, in The Works of Jeremy Bentham, ed. John Bowring, Vol. 1, 1843, Part I. http://oll.libertyfund.org/titles/bentham-the-works-of-jeremy-bentham-vol-1 (accessed 22.09.2017).

34. Frederick Rosen, Mill. Founders of Modern Political and Social Thought (Oxford: Oxford University Press, 2013), 135.

35. Rosen, 'Individual Sacrifice and the Greatest Happiness', 137.

36. Alexis de Tocqueville, Democracy in America (London: Bradley, 1840), Vol. 2, Pt 2, Chap. 1.

\section{Bibliography}

Amar, Akhil R. America's Constitution. A Biography. New York: Random House, 2006.

Bentham, Jeremy. Nonsense upon Stilts, or Pandora's Box Opened, or the French Declaration of Rights Prefixed to the Constitution of 1791 Laid Open and Exposed - with a Comparative Sketch of What Has Been Done on the Same Subject in the Constitution of 1795, and a Sample of Citizen Sieyès. In Rights, Representation and Reform. Nonsense upon Stilts and other Writings on the French Revolution, The Collected Works of Jeremy Bentham, edited by Philip Schofield, Catherine Pease-Watkin and Cyprian Blamires. Oxford: Clarendon Press, 2002. 
Bentham, Jeremy. Principles of the Civil Code. In The Works of Jeremy Bentham, edited by John Bowring, Vol. 1, 297ff. (1843). http://oll.libertyfund.org/titles/bentham-the-works-of-jeremybentham-vol-1 (accessed 22. 09.2017).

Burke, Edmund. Reflections on the Revolution in France. In Select Works of Edmund Burke. A new imprint of the Payne Edition, foreword and biographical note by Francis Canavan, Vol. 2. Indianapolis: Liberty Fund, 1999. http://oll.libertyfund.org/titles/656\#Burke_0005-02_277 (accessed 23. 09.2018).

Daniels, Roger. Franklin D. Roosevelt: The War Years, 1939-1945. Urbana, Chicago and Springfield: University of Illinois Press, 2016.

Dinwiddy, John R. 'Bentham'. In Bentham. Selected Writings by John Dinwiddy, edited by William L. Twining. Stanford: Stanford University Press, 2005.

Edmundson, William A. An Introduction to Rights. Cambridge: Cambridge University Press, 2004.

Escamilla-Castillo, Manuel. Bentham. Barcelona: RBA, 2017.

Hamilton, A., Madison, J. and Jay, J. The Federalist. In The Federalist, with Letters of 'Brutus', edited by T. Ball. Cambridge Texts in the History of Political Thought. Cambridge: Cambridge University Press, 2003.

Hayek, Friedrich A. The Road to Serfdom. In The Collected Works, Vol. 2. Chicago: University of Chicago Press, 2007.

Heale, Michael J. Franklin D. Roosevelt: The New Deal and War. London \& New York: Routledge, 1999.

Humboldt, Wilhelm von. The Sphere and Duties of Government. Translated by J. Coulthard. London: John Chapman, 1854. http://oll.libertyfund.org/titles/589\#1f0053_head_002 (accessed 15. 06.2018).

ICESCR. International Covenant on Economic, Social and Cultural Rights, 1966. https://www un.org/ruleoflaw/files/International\%20Covenant\%20on\%20Economic, $\% 20$ Social $\% 20$ and\%20Cultural\%20Rights.pdf (accessed 23. 09.2018).

Johnson, M. G. 'Internationalization of Human Rights'. In The Eleanor Roosevelt Encyclopedia, edited by Maurine H. Beasley, Holly C. Shulman and Henry R. Beasley, 256-260. Westport and London: Greenwood Press, 2000.

Rosen, Frederick. 'Individual Sacrifice and the Greatest Happiness: Bentham on Utility and Rights', Utilitas 10/2 (1998): 129-43.

Rosen, Frederick. Mill. Founders of Modern Political and Social Thought. Oxford: Oxford University Press, 2013.

Roosevelt, Franklin D. 'Message to Congress - The State of the Union' (speech file 1353A), 6 January 1941. In Master Speech File, 1898-1945, Franklin D. Roosevelt, Box 58, Franklin, in Franklin Delano Roosevelt Library and Museum. http://www.fdrlibrary.marist.edu/archives/ collections/franklin/index.php? $\mathrm{p}=$ collections/findingaid\&id $=582$ (accessed 14.06.2018).

Roosevelt, Franklin D. 'Radio Address to the Nation - Quoting State of the Union' (speech file 1502), 11 January 1944. In Master Speech File, 1898-1945, Franklin D. Roosevelt, Box 77, Franklin, in Franklin Delano Roosevelt Library and Museum. http://www.fdrlibrary.marist. edu/_resources/images/msf/msfb0131 (accessed 17.06.2018).

Schofield, Philip. Utility and Democracy. The Political Thought of Jeremy Bentham. Oxford: Oxford University Press, 2006.

Sen, Amartya. Inequality Reexamined. Oxford: Clarendon Press, 1992.

Tocqueville, Alexis de. Democracy in America. London: Bradley, 1840.

United Nations. Universal Declaration of Human Rights, 1948. http://www.un.org/en/universal-declaration-human-rights/ (accessed 16. 6.2018).

Vogel, Ursula. 'Liberty Is Beautiful: Von Humboldt's Gift to Liberalism', History of Political Thought III/1 (1982): 77-101. 


\section{9 \\ James Mill on Happiness}

Antis Loizides

James Mill (1773-1836) was the father of John Stuart Mill (1806-1873) and close collaborator of Jeremy Bentham (1748-1832). He was responsible for the education of the former and the propagation of the philosophy of the latter. These two sets of facts account for most of the interest in the elder Mill's works. They are also widely taken to sum up most of what is interesting in them. The truth of the first statement is undeniable; but, as I hope to show in this chapter, the truth of the second does not have to be. Typical as introducing an essay on Mill with reference to his son and Bentham may be, I argue that the elder Mill's conception of happiness was not typically Benthamic.

It is well known that, for James Mill, all the elements of happiness can be reduced to the simple sensations of pleasure and pain. Such a conception of happiness situates him squarely in the modern Epicurean tradition. Yet, on a number of occasions, he seemed to make a different kind of claim: that happiness involves the pursuit of what one 'deliberately approves'. Did he mean it when he pointed out that ideas of (future) pleasures - desires - 'are to be subjected to the sceptre of reason'? The view that a pleasure must be approved by reason - 'as a scene of trial' was Stoic, not Epicurean. In this chapter, I argue that the tension between such heterogeneous elements is more apparent than real: for Mill, the happy life is one in the service of the common good. To substantiate this claim, I bring to the fore the underlying conception of happiness in his arguments in the debates on the education of the poor in the 1810s and parliamentary reform in the 1820s. During these two decades, Mill clearly developed a Benthamic argument for social, educational and political reform. Taking the cue from his classical interests, I try to show that he threw something distinctive into the mix. James Mill was more than just Jeremy Bentham's lieutenant and John Stuart Mill's father. 
James Mill on happiness is a challenging subject - for a number of reasons. He was the author of The History of British India (1817), Elements of Political Economy (1821), Analysis of the Phenomena of the Human Mind (1829) and Fragment on Mackintosh (1835). Between 1806 and 1836, he wrote more than 150 articles in various periodicals and contributed a dozen essays to the Supplement to the Fourth, Fifth and Sixth Editions of the Encyclopaedia Britannica (1824). Prior to those, he made countless contributions to the Literary Journal and St. James's Chronicle, on both of which he served as editor between 1802 and 1806, as well as editing and translating an award-winning French essay in 1805. Never did he write an essay on what makes for a happy life, alas. Moreover, those who are familiar with his son's Autobiography (1873) may recall John Stuart's remark that his father had 'scarcely any belief in pleasure'. Still, as the younger Mill noted, though his father's personal outlook was rather Cynic and Stoic, '[h] is standard of morals was Epicurean, inasmuch as it was utilitarian'. ${ }^{1}$ Curious as it may be, this synthesis of philosophic elements does justice to his life-long interest in the classics, nonetheless.

Should one decide to look past John Stuart's indictment of his father's educational regimen and the famous critique of James Mill's utilitarian logic and politics by Thomas Babington Macaulay (18001859), there is still much need for reconstruction in attempting to extract a notion of happiness from the elder Mill's works. Mill's books, articles and essays were written for different purposes and under widely different circumstances. Not only did he rely on his journalistic activities, especially between 1802 and 1819, for his livelihood, but Mill was engaged in a number of debates throughout his career: writing on education, for example, he took the side of Joseph Lancaster over Andrew Bell; writing on India, he fought hard against the Orientalists; discussing good government, he wrote against both Tories and Whigs; he wrote on the side of associationist psychology, not 'innate-principle metaphysics'; ${ }^{2}$ and he wrote a long, vitriolic book defending Hobbes, Bentham and himself against the common-sense philosophy of James Mackintosh.

A question thus immediately presents itself: since a selection of the sources for the reconstruction is inevitable, what principle should guide it? The methodologically sound thing to do would be to focus on the debates themselves. It is reasonable to wonder whether there is a point in trying to bring statements on happiness together uttered with different aims in mind. The customary response to such concerns is simply to ignore them: Mill's contributions to all of the aforementioned debates are traditionally read through Bentham. As the story goes, Mill parroted Bentham, with the addition of a deductive, rationalistic, dogmatic and, 
simply, too serious frame of mind. Viewing Mill as merely the militant Benthamite, Leslie Stephen (1900) and Élie Halévy (1904) argued that there was an underlying unity in Mill's diverse aims: to propagate Benthamite utilitarianism. Mill stopped short of anything original and advanced little, if at all, beyond Bentham. This estimate has been proved double-edged: if we can make sense of Mill's chaotic writing by postulating a relentless resolve to preach Bentham's gospel, why bother with him at all? Why not go directly to the master himself? Accordingly, only a handful of scholars have seriously studied James Mill's works.

How does one go about addressing these issues? First, paying close attention to Mill's background, Terence Ball and Robert Fenn have dealt with the caricature of Mill as Bentham's mouthpiece decisively. ${ }^{3}$ Any reconstruction and any interpretation of Mill's thought must begin with his Scottish education, particularly his extraordinary classical training. His Commonplace Books showcase an extensive ancient Greek and Roman reading. ${ }^{4}$ Philosophers, orators, poets and historians such as Plato, Aristotle, Isocrates, Demosthenes, Herodotus, Thucydides, Xenophon and Diogenes Laërtius, as well as Cicero, Seneca, Quintilian, Tacitus, Livy, Pliny and Virgil, parade through the massive manuscript material. ${ }^{5}$ Plato's Socrates appears in these pages more frequently than William Paley, or David Hume and Adam Smith. Plato's and Aristotle's works, combined, appear as frequently as Jeremy Bentham's.

Second, most of Mill's utterances on happiness had two related aspects: personal cultivation and public usefulness. Both his numerous contributions on education - either to the Lancaster-Bell controversy (see below) or the debate on the philosophical (and psychological) foundation of education - and his essays arguing for parliamentary reform deserve full treatment; here I try to sketch a conception of happiness pervading these two sets of writings. In short, Mill argued that education was good to the extent that it associated the 'grand purposes' of life with pleasure; education produced those feelings, thoughts and actions that enabled a person to pursue her/his own happiness and the happiness of others. According to Mill, true public spirit, that is, 'a habitual and generous concern for the good of mankind', is the 'finest and rarest of all the fruits of cultivation'. ${ }^{6}$ A cultivated person, as much as a civilized society, Mill believed, acts to promote social happiness.

Third, for Mill, all of the elements of happiness can be reduced to the simple sensations of pleasure and pain. This well-known 'humble' sense of happiness situates Mill squarely in the Epicurean tradition - a tradition that, according to Frederick Rosen (2003), included David Hume, Adam Smith and Jeremy Bentham, among others. However, as I 
aim to show, the fuller picture is more complicated than that. According to Mill: (a) happiness consisted in pleasure and the absence of pain; (b) intellectual pleasures had much higher value than corporeal pleasures; (c) desires - roughly, for Mill, ideas of (future) pleasures - were 'to be subjected to the sceptre of reason'; (d) happiness involved the pursuit of what one 'deliberately approves'; and (e) one's happiness involved the pursuit of others' happiness. The Epicurean pedigree of Mill's conception is called into question when we try to make sense of the fourth claim happiness as the pursuit of what one 'deliberately approves' - in light of the third claim - ideas of pleasure are 'to be subjected to the sceptre of reason'. The view that an idea of a pleasure must be first approved by reason was Stoic in origin. But there is a second complication for Mill's conception of happiness when one understands claim (e) to mean a life of reason, activity and sacrifice, if need may be, in service of the greater good - a position more akin to a particular brand of Stoicism than the standard view of Epicureanism.

Here, I try to show that the contradiction that a mélange of such heterogeneous ideas might suggest, as regards the role of reason, desire and pleasure in Mill's theory, is more apparent than real. First, I present Mill's exposure to the classical tradition in the late eighteenth century, especially its relation to the vita activa. Second, I turn to the constituents of individual happiness as suggested in his educational tracts; and third, I focus on the constituents of social happiness as suggested in his parliamentary reform tracts. In Mill's works, the principle of utility becomes the keystone of the arch, keeping one's duties in proper order, leading one to pursue the higher rather than the lower good.

I

It is no secret that James Mill loved the classics. In his obituary of Mill in The Morning Chronicle in June 1836, John Black recorded that he had heard Mill 'speak with great warmth of the impression which the writings of Plato made on his youth'; leading him to 'regulate his conduct strictly according to an elevated ethical standard'. 7 Mill's fascination with the classics began at Montrose Academy in the 1780s; it remained strong throughout his life. He must have raised some eyebrows at the university library when, as a second-year divinity student, he added Plato to an already unusual reading list. Unsurprisingly in 1818, prior to his employment at the East India Company, Mill contemplated putting himself up for the Greek Chair at Glasgow. ${ }^{8}$ But there is no clearer testimony 
of what Mill thought about the worth of classics than the education of John Stuart Mill.

In his Autobiography, the younger Mill testified of his father's debt to Plato for his 'mental culture'. For John Stuart, both he and his father were Plato's students 'cast in the mould of his dialectics'. ${ }^{9}$ According to James Mill, Socrates never asserted an opinion himself, but always strove to reveal the limitations of popular beliefs. Mill, as with many others, accepted Cicero's verdict that Socrates 'brought philosophy down from heaven to earth', with the discovery of the rules and motives of good conduct contributing more than anything to 'advancement in life'. Mill seemed to believe that it was only through Plato's method that the rules and motives of good conduct could be discovered: Plato's dialectics deconstructed traditional modes of thinking and allowed philosophical enquiries by supposing nothing in advance. Plato's ingenious and eloquent dialogues, according to Mill, were most appropriate for 'sharpening' the 'ingenuity of youth' and 'engendering' 'the love of science and of virtue'. Such an attitude towards Plato was filtered through Cicero, who was an authority 'sufficient to confirm [Mill's] opinion respecting the writings of Plato'. Mill's acceptance of Cicero as an Academic led to a projection of that scepticism to Plato's dialogues; as Mill denied the possibility of Platonic dogmatism, the dialectic method itself was Plato's most valuable contribution. This reading of Plato's dialogues, which proved to be quite influential on John Stuart Mill, ${ }^{10}$ was not standard. James Mill's veneration for Cicero, in contrast, was.

Alexander Bain speculated that Mill remained six or seven years at Montrose Academy; his unusually long training at one of the few grammar schools in Scotland probably amazed his professors at the University of Edinburgh - he went in already an accomplished classical scholar. For example, his Professor of Greek, Andrew Dalzel, and his Professor of Logic, James Finlayson, recommended Mill as a tutor to various aristocratic families. ${ }^{11}$ But from all that time in Edinburgh, Mill held dear the memory of Dugald Stewart's lectures:

[...] for all the years I remained about Edinburgh, I used, as often as I possibly could, to steal into his class to hear a lecture, which always was a high treat. I have heard Pitt and Fox deliver some of their most admired speeches, but I never heard anything nearly so eloquent as some of the lectures of Mr. Stewart. I never heard anything like so fine a speaker. The taste for the studies which have formed my favourite pursuits, and which will be so to the end of my life, I owe to Mr. Stewart. ${ }^{12}$ 
Mill's classical background would prove especially relevant. Stewart's lectures, according to Stewart himself, 'were addressed to young men fresh from the study of the learned languages'; for this reason, he:

attempted often to strengthen and adorn my argument with such passages from Cicero and other ancients as left the deepest impression on my own memory, and which I therefore conceived to be most likely to awaken classical associations in the minds of my hearers, favourable to the truths which I wished to inculcate. ${ }^{13}$

It thus seems important to pause and consider eighteenth-century classical education, even if only briefly.

The 1831 report for the Royal Commission of Inquiry into the State of Universities of Scotland noted as a matter of regret that students engaged but superficially with the classics at the universities. ${ }^{14}$ That was a charge, however, that did not apply to late-eighteenth-century Edinburgh; its most esteemed professors pressed that antiquity had much to offer: Adam Ferguson and Dugald Stewart as Professors of Moral Philosophy, Hugh Blair as Professor of Rhetoric, and Andrew Dalzel as Professor of Greek. For them, classical philosophical, literary and historical works as well as the lives and ideas of seminal figures provided valuable lessons and models of excellence to young scholars.

Beginning from the last, in Dalzel's hands, 'the Greek Chair in Edinburgh was elevated from being the mere schoolmaster's rostrum to a living fountain, whence flowed in abundant streams, not only accurate knowledge of the language of Greece, but enthusiasm for its study all over Scotland' ${ }^{15}$ Like Dalzel, both Ferguson and Stewart shared the goal of 'mould[ing] teenage boys into virtuous, polite, tolerably learned, self-confident, upstanding, patriotic young gentlemen. ${ }^{16}$ Drawing inspiration from the ancients, these professors called their students to get to work for the betterment of society. Ferguson was praised, while still occupying the Chair, for 'taking a route different from his contemporaries'; 'direct[ing] philosophy to the heart', Ferguson had 'endeavoured to animate the coldness of modern times with the ardent spirit of antiquity; and, to a mercenary and luxurious age, has lifted up the voice which called the Greeks and Romans to virtue and glory'. ${ }^{17}$ In his Principles of Moral and Political Science (1792), which was to function as a textbook for his course, Ferguson even took a moment to respond to a charge of being partial to Stoics in some of the sections of that work and went on to list Lord Shaftesbury, Montesquieu and Hutcheson, among others, as admirers of Stoic philosophy, being 'acquainted with its real spirit'. ${ }^{18}$ Stewart succeeded Ferguson in the Moral Philosophy Chair in 1785. It had taken him 
no time at all to earn his students' affection; thanks to Ferguson himself, Stewart had surpassed his teacher's popularity among the students, while staying true to the spirit of Ferguson's teaching method. ${ }^{19}$ Just like Dalzel, Ferguson and Stewart, Blair was trying to inspire his students into virtuous action with eloquence as an effective means to that purpose. In the last lecture for his course on Rhetoric and Belles Lettres, Blair did not fail to offer important advice to his students:

I would thereof advice you to cultivate a taste for Virtue and Religion. This is a duty you owe to your friends, and I believe there is no one thing So favourable to the study of the liberal arts as the cultivation of a manly Spirit of Truth and piety, without this we can never relish the most refined beauty \& pleasure the human Soul is capable of enjoying and Virtuous minds alone are capable of that tender Sensibility which is absolutely necessary for excelling in the fine arts, and especially for the Noble purposes of Life. It is only persons of this temper of mind who can recommend religion \& Virtue with Success to others, and the greatest applause an Orator can receive, is that the Speaker, discovers himself to be a person of a worthy mind and endowed with the Same dispositions with which he endeavours to inspire his hearers. ${ }^{20}$

Hence, the link between education, the cultivation of virtue and activity was as ubiquitous in the classical and rhetorical courses as it was in the moral philosophy course at Edinburgh. The classics served as a bridge between the diverse aims of these courses, and Cicero was the main source. According to Günter Gawlick, Cicero's fame in the eighteenth century reached an astonishing peak: Enlightenment thinkers 'admired the statesman, the orator and the philosopher in him to an extent which, to the twentieth century observer, seems largely unwarranted'. ${ }^{21}$

Mill shared this passion for the classics with many of his contemporaries. And he kept returning to the classics throughout his life, adding to his Commonplace Books 'admirable', 'remarkable', 'good', quotations from Plato, Aristotle and Cicero, among others. Given the centrality of Cicero in classical education, since his works deal extensively with all ancient philosophical schools, Mill's readers would immediately identify the classical pedigree of his statements on happiness and on public duty. As George Nadel pointed out, scholars at times view 'as new and revolutionary certain ideas put forward by men like Bayle and Hume which, in fact, were merely paraphrases or quotations from the classics, drearily familiar to any educated person living between the Renaissance and the nineteenth century. ${ }^{22}$ 
There are many examples of Mill drawing from classical sources to express familiar utilitarian ideas in his manuscript notes. For example, for Mill, the principle of utility was 'founded by Plato', 'the philosopher of the most brilliant imagination', as outlined in three dialogues: Protagoras, Meno and Republic. In Protagoras, both interlocutors agreed that pleasures (and pains) need to be weighed and compared against their short-term and long-term consequences, including attributes such as intensity and quantity. However, such a calculation was not enough, Protagoras and Socrates agreed, as a person needs knowledge, or correct opinion, about the consequences of any given choice; that was the art of measurement - combining calculation with knowledge. As people never knowingly choose the lesser instead of the greater good, possessing this art is the key to a good life, Socrates argued. ${ }^{23}$ Plato's Republic moved the discussion from the individual to society. While Mill identified utilitarian thinking in passages in which calculation and reason appeared as the most important functions of the soul, he also pointed out that, for Plato, justice can make the state happy by uniting interests: the end to be sought was the happiness of all, not the happiness of just one social rank. ${ }^{24}$

In his copy of Cicero's Opera Omnia (Leiden, 1642), Mill marked the passage of Cicero's On Duties (3.11) where Socrates cursed those who first separated utility (utilitas) from justice (honestum). Likewise, Mill took note of Cicero's Letters to Atticus (8.11) on the task of the statesman as defined in On the Commonwealth (Bk 5):

this guide of the commonwealth aims at the blessedness of the life of his citizens, that they should be solid in their resources, rich in property, well endowed with glory, honorable in virtue. I want him to be the person to perfect this task, which is the greatest and best among mankind. ${ }^{25}$

Moreover, Mill cited Cicero's Letters to Quintus (1.24):

that those who govern others must gauge their every act by this one test - the greatest possible happiness of the governed [...]. And indeed it is the duty not only of one who governs allies and citizens, but also of one who governs slaves and dumb animals, to be himself a slave to the interests and well-being of those he governs. ${ }^{26}$

Given the emphasis on rational calculation, the pursuit of virtue and the promotion of social well-being, it does not come as a surprise that, even though Mill welcomed John Mason Good's English edition of Lucretius 
On the Nature of Things (1805), he scolded the translator for adopting the ethics of Epicurus:

What shall we say of a philosophy which accounted it the chief happiness of a being born to activity, and who can procure no happiness either to himself or to others but by action, to pass his life in complete indolence, to be wholly void of care, and to slumber away his existence in profound ease and repose? ${ }^{27}$

Importantly, Mill's verdict echoed Cicero's view on Epicurean $\mu \dot{\eta}$ $\pi o \lambda ı \tau \varepsilon v$ $\varepsilon \sigma \theta \alpha \imath$ (Letters to Atticus, 14.20, and On the Laws I.39). Since human beings are 'born to activity', there was no question more important than how to guide action. And that was primarily a question of education.

\section{II}

James Mill's publication record on education begins around $1806,{ }^{28}$ but his active engagement with public education is usually dated right after he commenced his association with Jeremy Bentham and Francis Place (1771-1854), that is, around 1808. Mill was involved in three different educational projects - an involvement that lasted until the early 1830s: primary education on monitorial educational principles (mainly for the poor); secondary education, that is, trying to establish a chrestomathic school in Bentham's garden (which, to Bentham's relief, was never implemented); ${ }^{29}$ and higher education, the founding of the University of London. Of all three projects, only the last came to fruition. ${ }^{30}$

Mill's writings on education culminated in the 1819 essay 'Education' for the Supplement to the Fourth, Fifth and Sixth Editions of the Encyclopaedia Britannica (1824). The very first sentence defined the end of education as clearly as possible: 'to render the individual, as much as possible, an instrument of happiness, first to himself, and next to other beings'. However, Mill - unexpectedly - shrunk from the task of defining happiness. In Section III, he acknowledged that the definition of happiness was of the highest importance for education, but he seemed to be content focusing on the means rather than the end. He outlined a 'humble', that is, experiential, and a 'higher', that is, transcendental, sense of happiness - the first being reduced in the simple sensations of pleasure and pain; the second drawing from a realm outside human sense-experience, cognizable only to the mind. Even though his analysis throughout the essay on education drew from the first 'school' of philosophers 
(Hobbes, Locke, Hume, Condillac, Helvétius, Hartley, Bentham, etc.), he chose simply to wrap up the discussion on the constituents of happiness as not yet conclusive and highly controversial.

The reason for Mill's argumentative strategy was clear, even if indirectly so. In the 1810s, Mill was engaged in a bitter dispute between the proponents of Lancaster's and Bell's systems as applied in the education of the poor - the former established schools more or less on secular principles, the latter on religious principles; the former featured members of a number of religious denominations in its ranks, the latter were members of the Church of England. All would agree that the best means of rendering the individual 'an instrument of happiness' involved inculcating the cardinal virtues - intelligence, temperance, justice and benevolence ('Education', Section II) - even if they disagreed on what 'happiness' consisted in. Not long before, Mill had argued that 'the moral duties [...] are the very bond of society; the foundation of all the happiness which human beings can enjoy; and on that account so deeply rooted in the affections of mankind, that any doctrine subversive of them would, together with its author, be sure of their detestation'. ${ }^{31}$

The public address to launch the West London Lancasterian Association, delivered on 2 August 1813, put together by James Mill, Francis Place and Edward Wakefield, offers the best summary of Mill's own views on education: '[i]n whatever degree happiness depends upon good conduct, and in whatever degree good conduct depends upon good understanding and good habits, in that same degree do happiness and good conduct depend upon training or education'. ${ }^{32}$ Around the same time, Mill pointed out that 'of all the circumstances which affect the happiness, the beauty, and order, and well-being of society, by far the most important' was character. ${ }^{33}$ Education was indeed the key to 'the greatest happiness of the greatest number'. ${ }^{34}$

In July 1812, writing in Eclectic Review, Mill noted that 'the property of knowledge [is] to elevate and refine our nature, - to enable a man to find satisfaction in his own bosom, - and, not only to produce a taste for intellectual delights, but to destroy the keen relish for gratifications purely sensual'. ${ }^{35}$ A month earlier, in the previous number of the same journal, Mill made a similar claim:

the pursuit of wisdom must mix itself with the pursuit of pleasure; the happiness of others must occupy the wish and prompt the endeavour, as well as the gratification or aggrandizement of self; the mind must be accustomed to consider this world not as a place of rest for the indulgence of irregular desire, but as a scene of trial 
where, by many conflicts and encounters, these desires are to be subjected to the sceptre of reason. The spiritual, in short, must take place of the sensual, and the infinite predominant over the finite. ${ }^{36}$

In Edinburgh Review, in 1813, Mill repeated that 'inward happiness [...] results from a mind lifted somewhat above the objects of mere animal pursuit, - qualified in some degree for the task of reflection, - and open to the innumerable delights which it brings' ${ }^{37}$ In the same year, he repeated that 'a perception of intellectual and moral objects' introduces one to 'other causes of pleasure than merely sensual'. The 'elevation of the people' was quite important in their pursuit of happiness - elevation 'above ignorance, above swinishness, above prostitute servility, above oppression, above delusion religious or political, above grovelling vice, above subjection to the irrational passions'; and the way to achieve it was through education. Mill could not have been clearer than in 1836: 'It is well-known how small is the value of all the merely corporeal pleasures, when taken nakedly by themselves, and without the addition of anything mental. ${ }^{38}$

The problem in Mill's conception of happiness is not the qualitative difference between pleasures. He ultimately resolved the issue as a question of quantity - 'the infinite' ought to be predominant over 'the finite'. The problem arises at the intersection of reason, desire and pleasure. What did Mill mean when he claimed that irregular desires 'are to be subjected to the sceptre of reason'? Does reason have priority or does pleasure have priority in guiding conduct? His 1819 essay on education only slightly improves the picture. Education, Mill argued, ought to furnish:

A perfect command [...] over a man's appetites and desires; the power of restraining them whenever they lead in a hurtful direction; that possession of himself which insures his judgment against the illusions of the passions, and enables him to pursue constantly what he deliberately approves, is indispensably requisite to enable him to produce the greatest possible quantity of happiness. ('Education', II.3)

In 1813, Mill explained the same phenomenon in different words, relegating reason to an instrumental, though still important, role:

Every man is guided by the pursuit of his own interest; and, in the way which he himself approves, endeavours to provide for the supply of his wants. The intelligence which may guide men in this 
process, alters nothing in its necessity. It only renders the quantity of their happiness greater, and that of their misery less. ${ }^{39}$

It seems that Mill's references to 'the sceptre of reason' and the process of deliberation have to do with the way in which one pursues her/his interests. In 1819, Mill was explicitly drawing on the 'temperance of the ancient philosophers' and intelligence, 'the strength which overcomes the misguiding propensities' as regards the best possible means to particular ends (the result of intelligence - knowledge and sagacity), as the constituents of individual happiness ('Education', II.3-4).

As we saw, by the late eighteenth century, there was already an established practice in place of drawing on Cicero in teaching moral philosophy; Cicero's 'modified Stoicism', Gloria Vivenza points out, became 'almost conventional'. ${ }^{40}$ Cicero claimed that for the Stoics, everybody by nature pursues those things that $\mathrm{s} / \mathrm{he}$ thinks to be good and avoids their opposites - when something that has the appearance of a good is presented to us, we naturally move to obtain it (Tusculan Disputations, 4.12). This means action; whether one will act to obtain something good or to avoid something bad depends on opinion and judgement (4.14). Once we assent to their being predicated either as good or bad, we act. But there is a right way and a wrong way to go about pursuing what presents itself as good, that is, the sage and the fool react differently to what seems good. For the wise person, desire is regular and consistent, that is, in accordance with reason; for the fool, it is irregular and unbridled, that is, in opposition to reason. The fool assents rashly to those impressions of the good or, in Zeno's terminology, the imprint - $\tau \dot{v} \pi \omega \sigma l \varsigma$ - on the soul (4.12, $13,15,80)$. Hence, one may be wrong in what $s /$ he comes to consider good either due to intemperance or simply because of ignorance - false information, ineffective comparison, flawed evaluation. It was temperance - self-control - that appeased the desires, making them obey right reason, as Cicero puts it, that is, maintaining the well-weighted judgements of the mind (4.22). Only sages never err in their judgement, since any wish for any object they might have is in accordance with reason (4.12). In Academica (I.42), Cicero noted that Zeno excluded from virtue and wisdom all error, rashness, ignorance, opinion, supposition - that is, everything foreign to stable and consistent assent. For the Stoics, virtue is right reason, Cicero reported; emotions distract, disrupt and disturb the mind; thus, emotions threatened the life of thought and tranquillity (Tus. Dis. 4.34). When something is presented to our senses, either with the appearance of a good or having already been predicated by others 
as good, it is still in the power of the individual to evaluate and choose whether to act on it $(4.65,76)$.

Mill's argument corresponded a great deal with Cicero's sketch of the Stoic theory of emotions. For, Mill, happiness depends upon the actions of individuals, and the actions of individuals depend upon their feelings and thoughts. Education must be structured upon the 'knowledge of the sequences which take place in the human feelings or thought' and aim 'to make certain feelings or thoughts take place instead of others' ('Education', I.19). The kinds of mental succession, upon which education works, make 'all the difference between the extreme of madness and of wickedness, and the greatest attainable heights of wisdom and virtue'. ${ }^{41}$ Since a person's bent of mind was revealed in the sequences of its ideas, the object of education was 'to provide for the constant production of certain sequences, rather than others', either through habit or through association with ideas of pleasure or pain ('Education', I.29).

The question for Mill's (and Cicero's) moral agents, then, turned into an epistemological one: how do they know a true good from a false good? According to Mill, given that 'our opinions are the fathers of our actions' and given that 'the actions of men are governed by their wills, and their wills by their desires', and 'their desires are directed to pleasure and relief from pain', ${ }^{42}$ it was vital for individuals not to take the opinions of others upon trust or let others choose opinions for them about what it is in their interest to pursue. ${ }^{43}$ It was thus quite an important educational end to create habits of examining the evidence that grounds opinions - a habit that begins, Mill maintained, with self-examination. ${ }^{44}$ The reason for this was the danger arising from the possibility of those who 'control' education attempting to form habits or associations that would not enable individuals to pursue their own happiness or, similarly, leading to them forming habits or associations that would enable individuals only to pursue what others think their happiness consists in. ${ }^{45}$ Just as government has the power to do 'good' through education, Mill argued, it also has the power to do 'evil'. Expectedly, Mill concluded that in order for social and political education not to create 'habits of servility and toleration of arbitrary power', it needs to be 'joined to another inestimable blessing': the liberty of the press. Uncensored public discussion, for Mill, had the Socratic function of developing an ability to form one's own own estimate of things. ${ }^{46}$

The 'business of a good education', according to James Mill, 'is to make the associations [of pleasure and pain] and the values [of the act] correspond' - that is, inclucating the cardinal virtues expands the 
associations of narrow interests to include social interests. Education must impart love for the ends of virtue, so that people can care enough to sacrifice 'part of the self which the good of our species requires'. ${ }^{47}$ The crucial distinction in Mill's conception of happiness, and the one that best accounts for the relation between reason, desire and pleasure, was not that of mental/sensual pleasures but that of self-regarding/other-regarding interests. To this question, we now turn.

\section{III}

Notwithstanding the ostensible Benthamite language as regards the simple elements of happiness - that is, the sensations of pleasure and pain Mill's conception of happiness is beginning to appear more distinctively his own. Mill's views in his final years were no different from when he took his first steps on the London scene. Writing in 1805, he argued that 'the business of all men who wish to benefit their species is to cultivate their reason not to listen to their passions, or temper, but to acquire a steady and perfect habit of consulting their reason solely, in a case in which it alone can give proper advice'. ${ }^{48}$ As we saw, the cultivation of knowledge and sagacity as well as temperance and fortitude 'appear to be sufficient for the happiness of the individual himself'. Similarly, justice - abstaining from doing harm - and generosity - doing positive good - suffice for the happiness of the community ('Education', II.4-5).

In an early unpublished piece of writing, Mill had already suggested a rule of thumb 'for fixing the gradation of pleasures, in point of respectability'. Nobler pleasures deserved more esteem; but the suggested rule went further than the simple distinction between the pleasures of the mind and the pleasures of the body: 'May we not reckon that the most important pleasure, by the want of which man would suffer the most?'49 According to Mill, since human beings would suffer most without society, those actions that promote the well-being of society are the most noble and those that hinder the well-being of society the most vicious. The first deserve our approbation; the second our disapprobation. In his magnum opus, Mill argued that, at a higher state of civilization, 'the mind of man is susceptible of pleasure from the approbation, pain from the disapprobation, of his fellow-creatures', which makes human beings 'capable of restraint'. ${ }^{50}$

In a series of essays in the 1820 s, beginning with 'Government' (1820) in the Supplement and culminating in 'Ballot' (1830) in Westminster Review, Mill expanded on the above idea via pushing an agenda of parliamentary reform. According to Mill, 'men, generally taken, will not 
only prefer their own interests to those of other men, but when they can, will sacrifice the interests of other men to their own'. ${ }^{51}$ Good government ensures the greatest sum of the scanty materials of happiness to the members of the community. This is achieved by preventing any group of individuals from making any other member weaker than that group, to have less than one's share of pleasures from one's own labour. However, since government involves transferring to a number of individuals enough power for the protection of all, by the above law of human nature, the same danger that exists outside the political community persists within the political community. Therefore, the community needs to prevent those who hold government power from abusing it. Protective measures included extensive suffrage in combination with frequent elections that would identify the interests of the community with the power-holders social happiness depended upon that identification of interests. ${ }^{52}$ The identification had to include the whole community:

When men are combined into an acting body, and have a kind of principle of unity bestowed upon them, it is universally recognized, that the interest of the body is the ruling principle of action. Their sympathies are with one another, not with those exterior parties whose interests come in competition with theirs. And as for virtue, in their case, who knows not, that in most minds, virtue consists in doing good to those with whom we sympathize? If there is any class of sensitive creatures, totally removed from our sympathies, we little regard the effects which our actions may have upon them. ${ }^{53}$

A review of James Mill's writings on good government throughout his authorial career suggests that he did not consider the identity of interests through representation the sole condition of good government. Even though he referred to other conditions - education, publicity, the 'fear of resistance' - the foundation of his argument in 'Government' and the many essays that followed was the state of interests. ${ }^{54}$

The question then to consider is how to escape 'self-love'. Even though we now move away from Mill's reform tracts, these ideas were embedded in them. In 1814, Mill had identified the reason for the selfish propensities in individuals, namely a bad education:

Under the coarse and unskilful tuition of rude and ignorant ages the dissocial passions are little subject to restraint; the selfish passions are allowed to operate freely and expand themselves; and no pains are employed to cultivate and to strengthen those principles of the 
mind by which we derive pleasure and pain from the happiness and misery of our fellow men. The youth under such a discipline, grows up into a man, having little regard for any other feelings than his own; occupied abundantly with the desire of his own happiness, but seldom troubling himself about the fate of others; little disposed to put himself to any inconvenience for promoting their happiness, or to make any sacrifice for alleviating their misery. ${ }^{55}$

In Analysis, Mill traced how human beings form attachments of friendship, kindness and compassion to others, beginning from family, party, country and mankind. Such relationships evince 'a principle of unity' as we saw, in which the members of a family, party, country and even mankind share in the causes of pleasure and pain - for example, if the well-being of their child does not form the primary concern in a family, it cannot be properly called a 'family'. ${ }^{56}$

The psychological principle involved in relationships was no different from that in other cases: the association of ideas. According to Mill, an association cluster is made up by numerous associations; what makes it a cluster, however, is that the feelings involved (sensations, thoughts, volitions) are so intimately blended 'that they no longer appear many, but one feeling. ${ }^{57}$ Often, however, in such indissoluble associations, the idea of the end drops out of sight, and the individual fixes on the means themselves. For Mill:

Wealth, Power and Dignity afford perhaps the most remarkable of all examples of that extraordinary case of association, where the means to an end, means valuable to us solely on account of their end, not only engross more of our attention than the end itself, but actually supplant it in our affections. ${ }^{58}$

For example, it is 'a vulgar observation, with respect to money', Mill pointed out, 'that, though useful only for obtaining pleasure, or saving from pain, it is often employed for neither purpose, but hugged as a good in itself'. 'Persons have been found', for another example, 'the one of whom could not endure to live without the other. ${ }^{59}$

We have already seen how Mill's educational theory, with direct bearing on individual happiness, expanded on familiar ideas from Cicero: individuals need to pause, consider and approve the course of action that was prompted by ideas of future pleasure (originating in one's own views of what is good or originating in what others denote as good). The preceding discussion, I think, allows us to view the emphasis on the identification of interests in Mill's reform tracts in a different light. 
We began with Mill's view that actions which promote the well-being of society are the most noble. We then moved to consider that while we deliberate on how to act in a given situation, we need to take under consideration how our actions affect 'the fate of others'. But we also saw that only when there is a 'principle of unity' with (some) others can we share in their pleasure and pain. We form some distinctive group of individuals when our actions tend to promote the good of the group. Noble as these actions may be, the most noble are those in which no class of 'sensitive creatures [is] totally removed from our sympathies'.

The cosmopolital ramifications of Mill's conception of happiness were obvious. And, once again, Mill's debt to Cicero manifests itself. As we saw, in his copy of Cicero's Opera Omnia, Mill marked a passage in Cicero's On Duties:

[...] And so, we have heard, Socrates used to pronounce a curse upon those who first drew a conceptual distinction between things naturally inseparable. With this doctrine the Stoics are in agreement in so far as they maintain that if anything is morally right, it is expedient, and if anything is not morally right, it is not expedient (Off. 3.11). ${ }^{60}$

In the third book of On Duties, Cicero brings honestum and utilitas together in a simple rule of conduct (3.19): 'This, then, ought to be the chief end of all men, to make the interest of each individual and of the whole body politic identical. For, if the individual appropriates to selfish ends what should be devoted to the common good, all human fellowship will be destroyed' (3.20). When people fail to recognize that they 'are bound to their fellow-citizens' by mutual obligations, social ties and common interests, 'the whole structure of civil society' falls apart (3.28). Of course, this did not mean that we are 'required to sacrifice our own interests and surrender to others what we need for ourselves, but each one should consider his own interests, as far as he may without injury to his neighbour's' (3.42). The 'good man', Cicero went on, 'will always perform his duty, promoting the general interests of human society' (3.31). The honestum, moral goodness, is what deserves most praise and all honour, even when no one praises or honours it (1.14).

The new element into the mix is thus not so new after all: virtue. According to Mill:

With the idea of our own acts of virtue, there are naturally associated the ideas of all the immense advantages we derive from the virtuous 
acts of our Fellow-creatures. When this association is formed in due strength, which it is the main business of a good education to effect, the motive of virtue becomes paramount in the human breast. ${ }^{61}$

But this is another example of indissoluble association; once the associated cluster becomes a single feeling, the attention moves away from the actual end, that is, pleasure (via praise or individual benefit); hence, Mill pointed out, the 'Praise, which we are never to hear, which will be diffused only when we are dead, and from which no actual effects can ever accrue to us, is often an object of intense affection, and acts as one of the most powerful motives in our nature. ${ }^{62}$ In the process of correcting Adam Smith's account of praiseworthiness, Mill argued that praise and blame 'are the great instruments we possess for ensuring moral acts on the part of our Fellow-creatures'. But we tend to deprive them of 'their useful tendency', by erroneously bestowing them, and thus 'we do what in us lies to lessen the quantity of Virtue, and thence of Felicity, in the world'. ${ }^{63}$

We are now in a position to fully unpack Mill's meaning. Any pursuit of ends is as a matter of suitably making appropriate associations of ideas. Via the example of writing, Mill argued that the end or ends of a discourse cannot be achieved without a proper combination of its many subordinate ideas: '[i]f every thing in the discourse tends to the accomplishment of the end, the Discourse is said to be coherent, appropriate, consistent'. Mill argued that living requires a similar ordering of ideas - some people actually manage to exhibit such 'steady direction of their actions, through the course of their lives, to some general end, or ends'. Happiness is said to predominate and control 'the associations in every part of the process' - as the 'grand suggesting principle' and the 'grand selecting principle', it suggests which trains of ideas are connected with happiness and selects which particular ideas can operate as causes to its attainment. This was what it meant to the elder Mill to have control over one's own ideas and actions. Such a steady pursuit of happiness becomes noble and commendable when the principle of utility keeps one's duties in the 'proper order' and leads one to pursue the higher rather than the lower good. ${ }^{64}$ The higher good is the common good:

When the grand sources of felicity are formed into the leading and governing Ideas, each in its due and relative strength, Education 
has then performed its most perfect work; and thus the individual becomes, to the greatest degree, the source of utility to others, and of happiness to himself. ${ }^{65}$

In his marginalia to Francis Hutcheson's A System of Moral Philosophy (1755), Mill noted that '[h] uman nature [is] not made up solely of desires, and propensities, which it is to obey indiscriminately. It has a principle of selection. That principle its ultimate end. An ultimate end is a thing felt, not reasoned about. ${ }^{166}$

\section{IV}

In April 1854, John Stuart Mill scribbled down in his journal that no longer was it necessary 'to sink altogether earthly happiness as a pursuit'. No puritanism, no asceticism was necessary: 'an earthly life', the younger Mill added, 'both pleasant and innocent can be had by many and might by all'. Instead, '[w] hat is now wanted is the creed of Epicurus warmed by the additional element of an enthusiastic love of the general good'. ${ }^{67}$ In this chapter, I have tried to show that this was exactly the way James Mill thought about happiness. On the one hand, deliberately approving what presents itself to us as a good was more about being able to question, examine and take control of the choice of action itself rather than simply being able to do what seems most expedient or pleasant to us, from the testimony either of our own experience or of others. On the other hand, acquiring the disposition to act virtuously means that the extrinsic worth of virtue, for instance, security and the reciprociation of benefits, has dropped out of sight. For the elder Mill, life in the service of the common good is simply the best kind of life. And that's unsurprisingly familiar. ${ }^{68}$

\section{Notes}

1. J. S. Mill, Autobiography (1873), in Collected Works of John Stuart Mill, 33 vols, gen. ed. J. M. Robson (London/Toronto: Routledge and Kegan Paul/University of Toronto Press, 1963-1991), vol. I, 49, 51. This edition of John Stuart Mill's works is hereafter cited as CW, followed by the volume and page number.

2. For the phrase, see J. S. Mill, Autobiography, CW, I.185, I.233.

3. See e.g. T. Ball, 'Platonism and Penology: James Mill's Attempted Synthesis', Journal of the History of Behavioural Sciences 18/3 (1982): 222-9, and T. Ball, 'Introduction', in James Mill: Political Writings, ed. T. Ball (Cambridge: Cambridge University Press, 1992), xi-xxvii. See also R. A. Fenn, James Mill's Political Thought (New York; London: Garland Publishing, 1987). 
4. Mill's Commonplace Books (hereafter, $\mathrm{CPB}$ ) form a variously organized collection of quotations, ideas and, at times, short drafts - arranged together from as early as his days at the University of Edinburgh - on a number of themes. The only extensive study on Mill's CPB is K. Grint, James Mill's Common Place Books and their Intellectual Context, 1773-1836, PhD Thesis (Sussex: University of Sussex, 2013). Volumes 1 to 4 of Mill's CPB are held at London Library; volume 5 at LSE Library Archives (Mill-Taylor Collection). Volumes 1 to 4, edited by R. A. Fenn and K. Grint, can be accessed at http://www.intellectualhistory.net/mill.

5. R. A. Fenn estimated that a printed edition of Mill's MS would amount to 1,200-1,300 pages (Fenn, Mill's Political Thought, iii).

6. James Mill, 'Schools for All', Philanthropist 4/16 (1814): 327. I follow Fenn's bibliography of Mill's works (Fenn, Mill's Political Thought, Appendix 2).

7. Quoted in A. Bain, James Mill: A Biography (London: Longmans, Green, 1882), 456.

8. Bain, James Mill, 14-5, 18-9, 166.

9. J. S. Mill, Autobiography, CW, I.24-5, I.24nC, I.48-9.

10. James Mill, 'Taylor's Translation of Plato', Literary Journal 3/8 and 10 (1804): 499-50 and 451-4; James Mill, 'Taylor's Plato', Edinburgh Review 14/27 (1809): 188-9, 191, 199-200. See further, A. Loizides, John Stuart Mill's Platonic Heritage: Happiness through Character (Lanham, MD: Lexington Books, 2013), Chs 3, 4, 6.

11. That the Marquis of Tweedale set up a small pension for James Mill, which he continued to receive for the rest of his life, confirms Mill's skills as an educator as well as the worth of the kind of education he offered. See A. L. Lazenby, James Mill: The Formation of a Scottish Émigré Writer, PhD Thesis (Sussex: University of Sussex, 1972), 309n94. The importance of being versed in classics was increasingly being felt at this time. In Loizides, J. S. Mill's Platonic Heritage, Chs 1 and 4, I dealt extensively with how eighteenth- and nineteenth-century debates on the classics served as a proxy for debates on political, social and educational issues.

12. J. Mill to M. Napier, 10 July 1821, in M. Napier (ed.), Selection from the Correspondence of the Late Macvey Napier (London: Macmillan, 1879), 27.

13. W. Hamilton, Collected Works of Dugald Stewart, 11 vols (Edinburgh: Thomas Constable, 1858-1878), Vol. VI, 116n.

14. Commissioners for Visiting the Universities and Colleges of Scotland, Report made to His Majesty by a Royal Commission of Inquiry into the State of Universities of Scotland (London: House of Commons, 7 October 1831), 25-6.

15. Anon., 'Review of History of the University of Edinburgh by A. Dalzel', The Athenaeum 1789 (8 February 1862): 181.

16. R. B. Sher, Church and University in the Scottish Enlightenment: The Moderate Literati of Edinburgh (Edinburgh: Edinburgh University Press, 1990), 118.

17. Cited in Sher, Church and University, 119.

18. A. Ferguson, Principles of Moral and Political Science, 2 vols (Edinburgh: William Creech, 1792), 8.

19. A. Dalzel to R. Liston, 16 February 1779, in C. Innes, Memoir of Andrew Dalzel (Edinburgh: Thomas Constable, 1861), 30-1. For Stewart's debts to Ferguson's mode of teaching, see Sher, Church and University, 124-5.

20. Cited in G. L. Hatch, 'Student Notes of Hugh Blair's Lectures on Rhetoric', in Scottish Rhetoric and its Influences, ed. L. L. Gaillet (London and New York: Routledge, 1998), 88. Mill owned (and took notes in) Blair's textbook on rhetoric.

21. G. Gawlick, 'Cicero and the Enlightenment', Studies on Voltaire and the Eighteenth Century 25 (1963): 657.

22. G. H. Nadel, 'Philosophy of History before Historicism', History and Theory 3/3 (1964): 292.

23. Mill, CPB, V.49r; V.83; V.107; I.52r. See Plato, Protagoras, 351b-9b and Meno, 88a-d.

24. Plato, Republic, 426d-e. See Mill's notes in I. Bekker (1826), Platonis et quae vel Platonis esse feruntur vel Platonica solent comitari scripta Graece omnia, 11 vols (London: A. J. Valpy, 1826), Vol. VI, 467, 601d-3a, 604d (notes in Bekker, Plato, VII.195ff), 351c-d and 462b in CPB, I.165r and I.166v. See also CPB, V.49r, V.107, I.52r on Protagoras, 351b-9b, Meno, 88a-d, and Republic, 420b. See also Mill's notes on Republic, 416a in CPB, I.166r (Bekker, Plato, VI.449); 462a-e at I.166v (Bekker, Plato, VI.527-8); and 412c-d in Bekker, Plato, VI.443. See further, Loizides, J.S. Mill's Platonic Heritage, Ch. 3.

25. CPB, I.168v and V.152v. The translation is from Cicero, On the Commonwealth and on the Laws, ed. and trans. J. E. G. Zetzel (Cambridge: Cambridge University Press, 1999).

26. CPB, I.208r. Translation is from W. G. Williams (trans.), Cicero's Letters to his Friends (Cambridge, MA: Harvard University Press, 1960). 
27. James Mill, 'Good's Lucretius', Literary Journal N.S. 1/1 (1806): 74.

28. E.g. James Mill, 'Lacroix, Essais sur l'Enseignement', Literary Journal N.S. 2/3 (1806): 321-30, and James Mill, 'Colquhoun's System of Education for the Labouring Poor', Literary Journal N.S. 2/5 (1806): 528-38.

29. Bain, James Mill, 86-8; W. H. Burston, James Mill on Philosophy and Education (London: Athlone Press, 1973), 71-2.

30. See further Burston, James Mill, Ch. 2; Bain, James Mill, Ch. 3; É. Halévy, The Growth of Philosophic Radicalism, trans. M. Morris (London: Faber and Faber, 1929 [1904]), 282-96.

31. James Mill, 'Toleration', Philanthropist 2/6 (1812): 108-24.

32. James Mill, Francis Place and Edward Wakefield, 'Report of a Meeting of the West London Lancasterian Association', Philanthropist 3/12 (1813): 359. See also, Burston, James Mill, 68. For accounts of this scheme, see G. Wallas, The Life of Francis Place, revised edn (London: George Allen and Unwin, 1918), Ch. 4; L. Stephen, The English Utilitarians, 3 vols (London: Duckworth, 1900), Vol. II, 21-2.

33. James Mill, 'Essays on the Formation of Human Character', Philanthropist 3/10 (1813): 97.

34. James Mill, 'Cappe on the Charity Schools, and other Important Institutions', Philanthropist 5/17 (1815): 2. See also, Burston, James Mill, 219; W. Thomas, The Philosophic Radicals (Oxford: Clarendon Press, 1979), 120; Fenn, Mill's Political Thought, 82ff.

35. Mill, 'Education of the Poor', Eclectic Review, 652.

36. James Mill, 'Madame Deffand's Correspondence', Eclectic Review 8/1 (1812): 560.

37. James Mill, 'Education of the Poor', Edinburgh Review 21/41 (1813): 209.

38. James Mill, 'Lancasterian Institutions', Philanthropist 3/12 (1813), 345; James Mill, 'Whether Political Economy Is Useful?', London Review 2/4 (1836): 558.

39. Mill, 'Lancasterian Institutions', 347.

40. G. Vivenza, Adam Smith and the Classics: The Classical Heritage in Adam Smith's Thought (Oxford: Oxford University Press, 2001), 42.

41. Mill, 'Formation of Human Character', 98.

42. James Mill, 'Government' (1820), in Essays; Reprinted, by permission, from The Supplement to the Encyclopaedia Britannica (London: J. Innes, n.d. [1828]), 14-15.

43. James Mill, 'Formation of Opinions', Westminster Review 6/2 (1826), 11ff., and James Mill, 'Liberty of the Press, (1821), in Essays, 21, 28-9.

44. Mill, 'Formation of Opinions', 10-11. See also, Mill, CPB, I.15 (on Plato, Gorgias, 480b-d, 521d-22a). Establishing habits of attending to evidence puts one on guard against the rewards of believing in a certain way', which 'makes the understanding, not the regulator of the will; but the pander to all its vices' (CPB, III.101v).

45. As Mill put it in his CPB (I.20r): 'The power of generating opinions by any thing but evidence', he argued, 'a power so useful for wicked purpose, so utterly needless for any good purpose, should be invariably wrested from the hands of the masters, and would-be oppressors of mankind'.

46. Mill, 'Liberty of the Press', 29-30; Mill, 'Education of the Poor', Edinburgh Review, 212. Mill extensively cited Plato's Apology with regard to uncensored discussion. See e.g. CPB, I.8r, 14r, $97 \mathrm{v} ;$ III.142v, 210v.

47. James Mill, Analysis of the Phenomena of the Human Mind, 2 vols (London: Baldwin and Cradock, 1829), Vol. II, 212-13; James Mill, The History of British India, 3rd edn, 6 vols (London: Baldwin, Cradock and Joy, 1826 [1817]), Vol. V, 527; James Mill, 'Fox's History of the Reign of James II', Annual Review and History 7 (1809), 100-3; Mill, 'Formation of Human Character', 111.

48. C. Villers, An Essay on the Spirit and Influence of the Reformation of Luther, ed. and trans. James Mill (London: C. and R. Baldwin, 1805), 35n.

49. Mill, CPB, II.4. In his editorial notes on Mill's CPB, Robert Fenn suggested 1806 as a possible date of this piece of writing.

50. Mill, History, II.433-4.

51. James Mill, 'Constitution; Constitutional Legislation', Parliamentary History and Review 3 (1828): 773 .

52. Mill, 'Government', 4-6.

53. James Mill, 'Constitution; Conduct of the late Parliament', Parliamentary History and Review 2/2 (1827): 773.

54. For a recent discussion, see A. Loizides, James Mill's Utilitarian Logic and Politics (London: Routledge, 2019), Ch. 6.

55. Mill, 'Schools for All', 327. 
56. Mill, Analysis, II.172ff.

57. Mill, Analysis, I.258.

58. Mill, Analysis, II.173.

59. Mill, Analysis, II.146, 177.

60. This translation is from Cicero, De Officiis, trans. W. Miller (Cambridge, MA: Harvard University Press, 1913).

61. Mill, Analysis, II.244-5.

62. Mill, Analysis, II.246-7.

63. Mill, Analysis, II.249-51.

64. Mill, Analysis, II.300ff. and 270.

65. Mill, Analysis, II.303.

66. Note in F. Hutcheson, A System of Moral Philosophy, 2 vols (London: A. Millar, 1755), Vol. I, 38.

67. J. S. Mill, Diary entry, 8 April 1854, CW, XXVII.666.

68. I am grateful to Georgios Varouxakis for reading and making insightful comments on earlier drafts of this chapter. This chapter is part of the dissemination activities of a research project on James Mill's political thought funded by the A. G. Leventis Foundation, Cyprus, 2017-2019.

\section{Bibliography}

Anon. 'Review of History of the University of Edinburgh by A. Dalzel', The Athenaeum 1789 (8 February 1862).

Bain, A. James Mill: A Biography. London: Longmans, Green, 1882.

Ball, T. 'Introduction'. In James Mill: Political Writings, edited by T. Ball, xi-xxvii. Cambridge: Cambridge University Press, 1992.

Ball, T. 'Platonism and Penology: James Mill's Attempted Synthesis', Journal of the History of Behavioural Sciences 18/3 (1982): 222-9.

Bekker, I. Platonis et quae vel Platonis esse feruntur vel Platonica solent comitari scripta Graece omnia, 11 vols. London: A. J. Valpy, 1826.

Burston, W. H. James Mill on Philosophy and Education. London: Athlone Press, 1973.

Cicero. De Officiis. Translated by W. Miller. Cambridge, MA: Harvard University Press, 1913.

Commissioners for Visiting the Universities and Colleges of Scotland. Report made to His Majesty by a Royal Commission of Inquiry into the State of the Universities of Scotland. London: House of Commons, 1831.

Fenn, R. A. James Mill's Political Thought. New York; London: Garland Publishing, 1987.

Ferguson, A. Principles of Moral and Political Science, 2 vols. Edinburgh: William Creech, 1792.

Gawlick, G. 'Cicero and the Enlightenment', Studies on Voltaire and the Eighteenth Century 25 (1963), 657-82.

Grint, K. James Mill's Common Place Books and their Intellectual Context, 1773-1836, PhD Thesis. Sussex: University of Sussex, 2013.

Halévy, É. The Growth of Philosophic Radicalism. Translated by M. Morris, 282-96. London: Faber and Faber, 1929 (1904).

Hamilton, W. Collected Works of Dugald Stewart, 11 vols. Edinburgh: Thomas Constable, 18581878.

Hatch, G. L. 'Student Notes of Hugh Blair's Lectures on Rhetoric. In Scottish Rhetoric and its Influences, edited by L. L. Gaillet. London and New York: Routledge, 1998.

Hutcheson, F. A System of Moral Philosophy, 2 vols. London: A. Millar, 1755.

Innes, C. Memoir of Andrew Dalzel. Edinburgh: Thomas Constable, 1861.

Lazenby, A. L. James Mill: The Formation of a Scottish Émigré Writer, PhD Thesis. Sussex: University of Sussex, 1972.

Loizides, A. James Mill's Utilitarian Logic and Politics. London: Routledge, 2019.

Loizides, A. John Stuart Mill's Platonic Heritage: Happiness through Character. Lanham, MD: Lexington Books, 2013.

Mill, James. Analysis of the Phenomena of the Human Mind, 2 vols. London: Baldwin and Cradock, 1829.

Mill, James. 'Cappe on the Charity Schools, and other Important Institutions', Philanthropist 5/17 (1815): 1-26. 
Mill, James. 'Colquhoun's System of Education for the Labouring Poor', Literary Journal N.S. 2/5 (1806): 528-38.

Mill, James. Commonplace Books, vols 1 to 4. Edited by R. A. Fenn and K. Grint. http://www.intellectualhistory.net/mill.

Mill, James. 'Constitution; Conduct of the late Parliament', Parliamentary History and Review 2/2 (1827): 772-802.

Mill, James. 'Constitution; Constitutional Legislation', Parliamentary History and Review 3 (1828): 335-74.

Mill, James. 'Education of the Poor', Eclectic Review 8/2 (1812): 651-58.

Mill, James. 'Education of the Poor', Edinburgh Review 21/41 (1813): 207-19.

Mill, James. 'Essays on the Formation of Human Character', Philanthropist 3/10 (1813): 93-119.

Mill, James. 'Formation of Opinions', Westminster Review 6/2 (1826): 1-23.

Mill, James. 'Fox's History of the Reign of James II', Annual Review and History 7 (1809): 99-114.

Mill, James. 'Good's Lucretius', Literary Journal N.S. 1/1 (1806): 69-90.

Mill, James. 'Government' (1820). In Essays; Reprinted, by Permission, from The Supplement to the Encyclopaedia Britannica, 14-15. London: J. Innes, n.d. (1828).

Mill, James. The History of British India, 3rd edn, 6 vols. London: Baldwin, Cradock and Joy, 1826 (1817).

Mill, James. 'Lacroix, Essais sur l'Enseignement', Literary Journal N.S. 2/3 (1806): 321-30.

Mill, James. 'Lancasterian Institutions', Philanthropist 3/12 (1813): 344-58.

Mill, James. 'Liberty of the Press' (1821). In 'Essays', 21, 28-9.

Mill, James. 'Madame Deffand's Correspondence', Eclectic Review 8/1 (1812): 547-62.

Mill, James. 'Schools for All', Philanthropist 4/16 (1814) .

Mill, James. 'Taylor's Plato', Edinburgh Review 14/27 (1809): 187-211.

Mill, James. 'Taylor's Translation of Plato', Literary Journal 3/8 and 10 (1804): 449-61 and 577-89.

Mill, James. 'Toleration', Philanthropist 2/6 (1812): 108-24.

Mill, James. 'Whether Political Economy is Useful?', London Review 2/4 (1836): 553-71.

Mill, James, Place, Francis and Wakefield, Edward. 'Report of a Meeting of the West London Lancasterian Association', Philanthropist 3/12 (1813): 358-74.

Mill, J. S. Autobiography (1873). In Collected Works of John Stuart Mill, 33 vols, general editor J. M. Robson, CW I. London/Toronto: Routledge and Kegan Paul/University of Toronto Press, 1963-1991.

Mill, J. S. Diary. CW XXVII.

Nadel, G. H. 'Philosophy of History before Historicism', History and Theory 3/3 (1964): 291-315.

Napier, M. (ed.). Selection from the Correspondence of the Late Macvey Napier. London: Macmillan, 1879.

Plato. Meno. In Platonis et quae vel Platonis esse feruntur vel Platonica solent comitari scripta Graece omnia, edited by I. Bekker, 11 vols. London: A. J. Valpy, 1826.

Plato. Protagoras. In Platonis et quae vel Platonis esse feruntur vel Platonica solent comitari scripta Graece omnia, edited by I. Bekker, 11 vols. London: A. J. Valpy, 1826.

Plato. Republic. In Platonis et quae vel Platonis esse feruntur vel Platonica solent comitari scripta Graece omnia, edited by I. Bekker, 11 vols. London: A. J. Valpy, 1826.

Rosen, Frederick. Classical Utilitarianism from Hume to Mill. London: Routledge, 2003.

Sher, R. B. Church and University in the Scottish Enlightenment: The Moderate Literati of Edinburgh. Edinburgh: Edinburgh University Press, 1990.

Stephen, L. The English Utilitarians, 3 vols. London: Duckworth, 1900.

Thomas, W. The Philosophic Radicals. Oxford: Clarendon Press, 1979.

Villers, C. An Essay on the Spirit and Influence of the Reformation of Luther. Edited and translated by James Mill. London: C. and R. Baldwin, 1805.

Vivenza, G. Adam Smith and the Classics: The Classical Heritage in Adam Smith's Thought. Oxford: Oxford University Press, 2001.

Wallas, G. The Life of Francis Place, revised edn. London: George Allen and Unwin, 1918.

Williams, W. G. (trans.). Cicero's Letters to His Friends. Cambridge, MA: Harvard University Press, 1960. 


\section{0}

\section{Bentham, Mill, Stoicism and Higher Pleasures}

Jonathan Riley

\section{Epicureans, Stoics and classical utilitarians}

I am delighted and honoured to contribute to this volume in celebration of my friend and colleague Frederick Rosen. Fred and I share an interest in classical hedonistic utilitarianism and its relations to ancient Greek philosophy. But whereas he tends to argue that Jeremy Bentham largely anticipates John Stuart Mill's utilitarianism - with the caveat that Mill tries to integrate elements of Stoicism with the Epicurean tradition that is a predominant influence on both of them - I claim that Mill's utilitarianism is a truly novel doctrine that goes beyond Bentham's but does not involve any commitment to Stoicism. Unlike Bentham, Mill conceives of pleasure as a family of higher and lower kinds of feelings that are incommensurable with one another in the sense that a higher pleasure has a superior intrinsic quality of tone as pleasure, regardless of quantity.

I can think of no better way to show my gratitude and respect than to offer a critique of Fred's interpretation of Bentham and Mill with respect to two main points. On the one hand, I will argue against his view that Bentham's account of different sorts and qualities of pleasures shows that Bentham no less than Mill accepts that pleasures may be incommensurable. On the other hand, I will also challenge his reading of the character of Mill's hedonistic account of the virtues, which does not involve an embrace of elements of Stoicism. In combination, these two lines of criticism should help to clarify the deeper issue about how to interpret the differences between Bentham and Mill. 
Rosen argues that Bentham and Mill belong within the Epicurean tradition because, like the Epicureans, they insist that the ultimate human good is happiness in the sense of pleasure and exemption from pain. ${ }^{1}$ They share the Epicureans' commitment to hedonism, even if the utilitarians are concerned with promoting collective happiness whereas the Epicureans focus on the promotion of personal happiness. ${ }^{2}$

However, unlike Bentham, Rosen claims, Mill modified or qualified his hedonism by combining Epicureanism with elements of Stoicism within his version of utilitarianism. Whereas Bentham dismissed the Stoics as ascetics who were opposed to the greatest happiness principle, Mill distinguished between the Stoics and ascetics: the Stoics, unlike the ascetics, who said that 'pain is a good, and pleasure an evil', said only that 'pain is no evil, and pleasure no good'. ${ }^{3}$ As a result, Rosen says, 'Mill tended to treat the Stoics more sympathetically than those he often referred to as "Puritans" or "ascetics". ${ }^{4}$ In particular, when he wrote in Utilitarianism that it was better to be Socrates dissatisfied than a pig or a fool satisfied, Mill's 'agenda ... was to prise elements of Stoicism away from Puritanism and link them to the Epicurean tradition'. ${ }^{5}$

According to Rosen, by linking elements of Stoicism with Epicureanism, Mill made room for an ethics of personal sacrifice within utilitarianism and at the same time mounted a powerful attack against Thomas Carlyle's 'new form of Puritanism', according to which human beings had no right to happiness and ought to renounce it as an unworthy goal:

By taking elements of Stoic thought into his approach ... Mill could juxtapose a new kind of utilitarian hero who embraced sacrifice but, unlike Carlyle, did not renounce happiness. The utilitarian hero (or martyr) could sacrifice his or her own happiness to serve the happiness of others, and Mill considered such a sacrifice to constitute the highest virtue. ${ }^{6}$

For Rosen, it seems, Mill's main purpose when he asserted that it was better to be Socrates dissatisfied was to set the stage for his rejection of 'Carlyle's belief that men lived and could live well without happiness'.'

While Rosen is certainly right that Mill firmly rejected Carlyle's asceticism and love of German metaphysical idealism, ${ }^{8}$ it is not clear how a turn to Stoicism is supposed to help us to understand Mill's claim that it is better to be Socrates dissatisfied or his claim that hedonistic utilitarianism can consistently accommodate the sacrifice of personal happiness. Bentham is correct that the Stoic maxim that 'pain is no evil, and pleasure 
no good' is incompatible with Epicureanism as well as with hedonistic utilitarianism. Indeed, when Mill distinguishes between the Stoics and religious ascetics, he is doing so as part of his general defence of Bentham from William Whewell's charges that Bentham makes absurd assertions about morality. According to Mill, Bentham is right to regard ascetics and Stoics as opponents of hedonism and hedonistic utilitarianism. ${ }^{9}$

Rosen apparently believes that Mill's claim can be justified 'in a straight-forward manner' by using aspects of Stoicism to extend the Epicurean view that prudent egoists can find greater personal happiness than fools can:

Even though happiness, derived from the higher pleasures, might leave the individual subject to acute suffering, and the intelligent person might need more to make him- or herself happy, [Mill] invoked Stoic themes, such as a love of liberty, independence, and a sense of dignity, to give greater force to his view that it was better to be Socrates dissatisfied than a fool satisfied. ${ }^{10}$

But how does this explain that Socrates experiences greater happiness than a fool, especially in light of the admission that Socrates is exposed to more acute pains than the fool is? Socrates is said to be dissatisfied, that is, discontented, which seems to imply that he is unhappy, at least without further explanation. If pleasure is a homogeneous feeling across its various sources, as Bentham and the Epicureans assume, it is undeniable that the dissatisfied Socrates may experience a smaller amount of pleasure and security from pain than the satisfied fool does. Moreover, if it is maintained nonetheless that it is better to be Socrates dissatisfied, the term 'better' must be justified in terms of some value other than happiness in the sense of pleasure and immunity from pain. In short, the turn to Stoicism seems to imply that Mill abandons hedonism, as his critics so often complain.

I will argue against Rosen that Mill never accepts the Stoic maxim that 'pain is no evil, and pleasure no good' and that he does not rely on it to construct his unusual version of hedonistic utilitarianism. In Section II, I maintain that, although neither Bentham nor Mill makes self-interest constitutive of virtue, Bentham's preoccupation with self-interest as a motive leads him to concentrate on the need for external sanctions to make selfish people do right whereas Mill emphasizes that cultivated people also develop higher moral motives that drive them to willingly do right and to pursue ideal ends for their own sake. For Mill, while Bentham acknowledges that one person can sympathize with another, he fails to 
recognize the power of a disinterested conscience to override self-interest in cases of conflict. In Section III, I claim that Bentham's talk of quantities and qualities of pleasure does not anticipate Mill's doctrine of higher pleasures. For Bentham, pleasant feelings are homogeneous and vary only in terms of quantity: the idea of higher kinds of pleasant feelings superior in quality to other kinds is foreign to his thought. In Section IV, I suggest how Mill uses higher pleasures to justify his claim that it is better to be Socrates dissatisfied than a pig or fool satisfied. Section $\mathrm{V}$ concludes with arguments that higher moral pleasures can motivate cultivated people to voluntarily sacrifice self-interest to fulfil their moral duties, and that higher aesthetic pleasures can motivate heroic individuals to willingly go beyond duty by sacrificing even their own lives to promote greater happiness for others.

\section{Between Bentham and Mill}

It might be questioned whether Bentham saw the need for any distinction between rational self-interest and moral virtue since, if we accept Sidgwick's reading, Bentham believes that a person's self-interest, properly calculated, always coincides with the community's greatest total happiness:

in the Deontology ... it is distinctly assumed that, in actual human life as empirically known, the conduct most conducive to general happiness always coincides with that which conduces most to the happiness of the agent; and that 'vice may be defined as a miscalculation of chances' from a purely mundane point of view. ${ }^{11}$

Mill rejects such a reading of Bentham, on the grounds that the Deontology was cobbled together by John Bowring from Bentham's unpublished manuscripts and gives a distorted picture of Bentham's utilitarian theory of morality. ${ }^{12}$

Mill insists that, for Bentham, self-interest is not constitutive of morality or the test of virtue. Rather, Bentham accepts that morality involves an impartial concern for the good of the community (everybody to count for one, nobody for more than one). For him, the test of virtue is promotion of general happiness. As Rosen puts it:

Bentham depicts the 'partisan' of the principle [of utility] not as one who calculates his pleasures and pains from self-interest, but one 
whose 'approbation or disapprobation ... is determined by, and proportioned to the tendency which he conceives it to have to augment or to diminish the happiness of the community'. ${ }^{13}$

But while Bentham does not reduce virtue to self-interest, it seems accurate to say that, for him, self-interest is a predominant motive. True, he also recognizes sympathy for others as a motive. But he 'felt the inadequacy of [it], except in certain limited cases, as a security for virtuous action. ${ }^{14}$ Bentham understood that personal affection is liable to involve antipathy towards third parties and operate to their harm, Mill says, and thus needs to be regulated. In other words, Bentham typically conceives of sympathy as what Mill calls 'sympathetic selfishness', in the sense that self-interested people sympathize only with certain others such as family and friends whom they associate with their own interests. ${ }^{15}$ Such people do not sympathize impartially with their fellow sentient creatures, as a highly cultivated moral agent does. Bentham also understood that 'general philanthropy, considered as a motive influencing mankind in general' is 'the very weakest and most unsteady of all feelings'. ${ }^{16}$ 'There remained, as a motive by which mankind are influenced, and by which they may be guided to their good, only personal interest. ${ }^{17}$ In short, for Bentham, conduct is governed in the main by 'the different modifications of self-interest, and the passions commonly classed as selfish?. ${ }^{18}$

Given his preoccupation with self-interest as a motive, Bentham argues that external sanctions must be deliberately employed by government officials and other agents to bring an individual's self-interest into harmony with the utility principle. As he says: '[W] hatsoever evil it is possible for man to do for the advancement of his own personal and private interest ... at the expense of the public interest - that evil sooner or later, he will do, unless by some means or other ... he be prevented from doing it'. ${ }^{19}$ External sanctions cannot always be effectively employed, however, and Bentham does not assume that rational egoists will choose virtuous actions in the absence of such sanctions.

Bentham's focus on self-interest as a motive and on the need for external sanctions to channel and redirect self-interest for the public good is central to his version of hedonistic utilitarianism. He classifies external sanctions as physical, political, popular or moral, and religious. When he speaks of naked physical sanctions, he is referring to physical sensations of pleasure and pain that are caused in us by natural forces, unaided by the efforts of other people or by the supernatural interventions of gods. These physical or bodily feelings are external in two related senses: they apparently originate in various external natural objects and 
events, and they are conveyed to our consciousness by the nervous system, independently of our will and other higher mental faculties. Such elementary feelings of pleasure and pain are alone what can ultimately make individuals do something, whether they wish to or not: 'there is nothing by which a man can ultimately be made to do [something], but either pain or pleasure'. ${ }^{20}$ They are 'sovereign masters' imposed on us by nature. ${ }^{21}$

The other three sanctions he identifies are parasitic on the physical sanctions:

Of these four sanctions the physical is altogether ... the groundwork of the political and moral [or popular]: so is it also of the religious, in as far as the latter bears relation to the present life [here on earth]. It is included in each of the other three ... In a word, the powers of nature may operate of themselves; but neither the magistrate, nor men at large, can operate, nor is God in the case in question supposed to operate, but through the powers of nature. ${ }^{22}$

The political, popular and religious sanctions are external sanctions employed by other agents as instruments or incentives to make predominantly self-interested individuals do what is just and right as opposed to what is selfish and immoral. Bentham typically conceives of these external sanctions in terms of punishments rather than rewards because he believes (like the Epicureans and Mill, among many others) that sensations of pain are more acute than sensations of pleasure. But he does not assume that these incentives can invariably work to make selfish individuals take the same virtuous actions as would be taken voluntarily by cultivated moral agents.

Mill objects that Bentham 'overlooks ... the moral part of man's nature, in the strict sense of the term - the desire of perfection, or the feeling of an approving or of an accusing conscience':

Man is never recognised by him as a being capable of pursuing spiritual perfection as an end; of desiring, for its own sake, the conformity of his own character to his standard of excellence, without hope of good or fear of evil from other source than his own inward consciousness ... Nothing is more curious than the absence of recognition in any of his writings of the existence of conscience, as a thing distinct from philanthropy, from affection for God or man, and from self-interest in this world or in the next ... If we find the words 'Conscience', 'Principle', 'Moral Rectitude', 'Moral Duty', in his Table 
of the Springs of Action, it is among the synonymes [sic] of the 'love of reputation'; with an intimation as to the two former phrases, that they are also sometimes synonymous with the religious motive, or the motive of sympathy. The feeling of moral approbation or disapprobation properly so called, either towards ourselves or our fellow-creatures, he seems unaware of the existence of. ${ }^{23}$

Not only does he overlook the moral desire to do right for its own sake and associated internal sanctions of guilt and remorse, Mill claims, "he but faintly recognises, as a fact in human nature, the pursuit of any other ideal end for its own sake .... [ [N]o conclusions are ever founded' on the 'sense of honour, and personal dignity - that feeling of personal exaltation and degradation which acts independently of other people's opinion, or even in defiance of it', for example, or 'on the love of beauty, the passion of the artist'. ${ }^{24}$

In Mill's judgement, Bentham works with a simplistic conception of human nature that exaggerates the place of selfish motives to the neglect of 'deeper feelings': 25

If he thought at all of any of the deeper feelings of human nature, it was but as idiosyncracies of taste, with which the moralist no more than the legislator had any concern, further than to prohibit such as were mischievous among the actions to which they might chance to lead. To say either that man should, or that he should not, take pleasure in one thing, displeasure in another, appeared to him as much an act of despotism in the moralist as in the political ruler. ${ }^{26}$

As a result, Bentham's version of utilitarianism is a narrow and impoverished doctrine. In contrast, Mill aims to take account of higher moral and aesthetic feelings of pleasure that can motivate virtuous people to voluntarily sacrifice their own interests and even their lives to promote the collective happiness, without any need for others to employ external sanctions to make them take such sacrifices. In other words, he never rejects hedonistic utilitarianism. Instead, he objects to Bentham's preoccupation with self-interest and neglect of higher moral and aesthetic motives. He seeks to enlarge utilitarianism so that it duly recognizes the importance of the higher pleasant feelings while retaining whatever is valuable in Bentham's philosophy with its focus on self-interest and external sanctions.

Bentham and Mill can both endorse the Epicurean claim that a wise egoist will be happier than a fool. A prudent person can find greater 
personal happiness by sacrificing his/her own immediate pleasures for the sake of greater personal pleasures in the future. Such a person might also prefer a life of relative isolation and tranquillity, if the Epicureans are correct to think that others are likely to cause that person more acute pains than pleasures. But their acceptance of these points does not commit the utilitarians to a belief that a wise egoist will voluntarily sacrifice his/her own pleasure so as to promote the pleasures or mitigate the pains of other people.

Some may argue roughly in the spirit of Epicureanism that wise egoists will consent to adopt social rules of justice and right that protect their own shared vital interests, rules including laws and customs that will be enforced by the wise against any fools who are inclined to cause wrongful harm to others. The social code of rules is for the mutual advantage of the wise, it may be said, and well-designed external sanctions employed by them can force imprudent egoists to fulfil their moral duties to others out of fear of social punishment, including legal penalties and public humiliation and stigma.

But at least three related objections cast severe doubt on this argument. First, rational egoists, and not only fools, have incentives to break the rules and will take immoral and illegal actions when they believe they can do so without detection by others. Second, rational public officials must be compensated to employ external sanctions to prevent or punish wrongdoing, but egoistic taxpayers are unlikely to pay the required total compensation, in which case the sanctions will not be effectively implemented. Third, external sanctions cannot be effectively employed to deter wrongdoing in some situations anyway - for example, confidential private engagements: they cannot always make up for the selfish agent's lack of a strong conscience or lack of disinterested desire to do right for its own sake.

Bentham's narrow utilitarianism is vulnerable to these objections. In light of Mill's considered complaint that higher moral and aesthetic motives play no effective role in it, Bentham's doctrine is unable to overcome this vulnerability by relying on internal sanctions of guilt and dishonour that, when sufficiently powerful, motivate an individual to choose virtuous actions without any need for others to employ external sanctions. In contrast, Mill insists that there are higher kinds of pleasant feelings that are properties of the moral and aesthetic sentiments. His enlarged utilitarianism makes room for cultivated individuals who, after developing their capacities to appreciate the higher pleasures, conscientiously fulfil their moral duties to others whenever possible, even when doing so is contrary to their selfish interests. The threat of self-inflicted 
guilt and shame caused by frustration of their moral desire to do right for its own sake prevents them from acting on their selfish desires. These cultivated individuals may even freely take praiseworthy supererogatory actions that they have no moral duty to take, sacrificing their own lives and property for the sake of others. A lofty aesthetic ideal of personal honour, the disappointment of which is intolerable to them, might prompt them to take such heroic actions.

The moral desire to always fulfil one's duties to one's fellow creatures and the aesthetic desire to take admirable supererogatory actions on their behalf are both inexplicable by hedonists if self-interest is a predominant motive such that a wise individual will refuse to do these things in the absence of external sanctions imposed by others. Hedonists cannot maintain that external sanctions are always effective in enforcing moral duties. Nor can they argue that external sanctions are legitimately employed to force any individual to take admirable supererogatory actions that may severely harm or even kill that person. By emphasizing that the individual can become competently acquainted with the higher pleasures, Mill aims to show that an enlarged hedonistic utilitarianism can accommodate voluntary sacrifices of selfish interests. His utilitarian doctrine endorses even extreme supererogatory sacrifices by virtuous heroes or saints who willingly give up their own lives to promote greater happiness for others.

\section{Higher pleasures}

Bentham apparently conceives of pleasure as a homogeneous positive feeling that varies only in quantity, and of pain as a negative homogeneous feeling that must be deducted from pleasure. In his view, pleasure can be understood to include relief from pain since adding to a sum total of pleasures 'comes to the same thing' as diminishing a sum total of pains. ${ }^{27}$ As pointed out earlier, he focuses attention on physical sensations of pleasure and pain, and urges that these physical sanctions ought to be deployed in political, popular and religious sanctions designed to make selfish people comply to some extent (necessarily imperfect) with reasonable social rules of justice and right. Given that the physical sensations of pleasure and pain are typically experienced as ingredients of mental pleasures and pains, and given that pleasure can be taken to include security from pain, he is preoccupied with one kind of mental pleasures - namely, selfish pleasures that the individual believes (perhaps mistakenly) are expedient in terms of his/ her own interests. It is a sound inference that the intrinsic nature or tone 
of these selfish pleasant feelings is similar across individuals, even though different people may get their pleasure from different objects and events and also experience different amounts of it from any particular object or event. ${ }^{28}$ People who are competently acquainted with these selfish pleasures agree that the feelings comprise a single selfish kind. Any competent individual who has, or once had, a predominantly selfish character recognizes that the feelings feel alike to him/her and infers that the same is true for other competent people.

Sidgwick, Moore and virtually everyone in their trail have argued that hedonism cannot dispense with the assumption that pleasure, including relief from pain, is a homogeneous feeling. Rosen does not dispute this received view. Rather, he emphasizes that Bentham, like Hume, subscribed to 'the Epicurean doctrine of the unity of pleasure', according to which one pleasant feeling feels like any other apart from quantity:

[Hume] never paused to consider different kinds of pleasure and pain. If utility pleased, the pleasure it provided was like any other pleasure. Bentham would fully agree. The various categories depicted in IPML led to no conclusions regarding some pleasures being superior to any others. ${ }^{29}$

As Rosen points out, the unity of pleasant feelings doctrine is compatible with the fact that different sources of this feeling, such as the activities of contemplation and of eating, can produce different amounts of it: 'this is not to deny that one might obtain greater pleasure from contemplation than from eating (from the satisfactions of Socrates as opposed to those of a pig [or fool] ${ }^{30}$

Nevertheless, Rosen also challenges the received view, in particular, with respect to what may be called its decisiveness. In his opinion, Bentham's hedonism involves different kinds of pleasures that have incommensurable qualities so that they cannot be added into a sum total. He emphasizes that Bentham sees a feedback between quality and quantity that makes it difficult if not impossible to disentangle them when measuring pleasure and pain. To support his interpretation, he argues that when 'Bentham listed fourteen kinds of pleasure and twelve kinds of pain, he was referring to different qualities of pleasure and pain, which he had delineated on the basis of careful observation and deduction' ${ }^{31}$ As he elaborates the point:

Hence the pleasures of memory or expectation were different from the pleasures of skill and pleasures of power. For Bentham one 
could not say that the possession of various skills generated more or less pleasure than the possession of power, as they referred to different kinds of pleasures which were not commensurable..${ }^{32}$

Different kinds of pleasures apparently involve different qualities that are non-comparable, where the differences are rooted in the different sources of the pleasures. Distinct sources such as memory and possession of skills result in different kinds and qualities of pleasures. Perhaps multiple pleasures of the same kind and quality can be summed, Rosen seems to believe, but different kinds and qualities of pleasures cannot be summed because they are incommensurable.

However, as Rosen recognizes when discussing the doctrine of the unity of pleasant feelings, Bentham is not denying that the feeling of pleasure itself is homogeneous, though it arises from different sources. He is not saying that the pleasant feelings arising from one source are intrinsically more valuable as pleasure than the pleasant feelings arising from another. For Bentham, pleasant feelings are homogeneous feelings - more specifically, positive self-interested feelings whose intrinsic tone is the same across various sources. What he calls different kinds of pleasures are different manifestations of this homogeneous selfish pleasant feeling, whoever feels it and whatever objects or events are its sources. ${ }^{33}$

Rosen also argues in support of his reading that 'when Bentham listed seven "elements" or "dimensions" of value (intensity, duration, certainty, propinquity, fecundity, purity and extent), he might have been referring to quantitative assessment, but the elements or dimensions comprise different qualities of measurement concerning pleasure and pain'. ${ }^{34}$ He suggests that Bentham does not mean to imply that all of these qualitative dimensions of quantitative measurement can be added together to give a single sum total of pleasure or pain: 'It would be difficult to weigh up the intensity and purity of a pleasure in one sum, though not impossible to suggest that one pleasure was more intense than another or purer [than another, in the sense that the one was mixed up with less pain than the other]'. ${ }^{35}$ But this is incompatible with what Bentham actually says in the fourth chapter of IPML, despite Rosen's attempts to divert attention by stressing the incommensurabilities, the limitations of quantitative measurement, and Bentham's failure to 'provide any mathematical formula' to clarify how to "sum up" first pleasures and then pains. ${ }^{36}$

According to Bentham, the value or quantity of a pleasure or pain per se is measured by considering the four dimensions of intensity, duration, certainty and propinquity. These four dimensions 'are to be considered in estimating a pleasure or a pain considered each of them by 
itself' ${ }^{37}$ In other words: 'To a person considered by himself, the value of a pleasure or pain considered by itself, will be greater or less, according to the four [dimensions]. ${ }^{38}$

Contrary to Rosen, these four 'qualitative' dimensions of quantity can be estimated and then put into a formula to calculate a single total quantity or value of pleasure or pain. Let $x$ be the intensity of a homogeneous pleasant feeling $P$, estimated in terms of a cardinal scale of units of the feeling per period of time, with a larger number of units corresponding to a more intense or stronger feeling; let $y$ be the duration of $P$ measured in terms of periods of time, say, minutes; $w$ be the certainty of $\mathrm{P}$ measured in terms of the probability (on a scale of zero to one) of experiencing it; and $\mathrm{z}$ be the propinquity of $\mathrm{P}$ measured in terms of a discount rate that varies (on a scale of zero to one) depending on how near or distant the pleasant experience is expected to occur. ${ }^{39}$ Assuming for convenience that intensity is constant over the duration of $\mathrm{P}$, we have:

$$
\mathrm{V}(\mathrm{P})=\mathrm{Q}(\mathrm{P})=\mathrm{xywz}(\mathrm{P})
$$

where $\mathrm{V}(\mathrm{P})$ is the value of $\mathrm{P}, \mathrm{Q}(\mathrm{P})$ is the total quantity of $\mathrm{P}$, and $\mathrm{xywz}$ is the product of the four dimensions of quantity. An analogous formula applies to pain.

Bentham tells us that the remaining three dimensions of quantity come into play only in the hedonistic evaluation of actions or events: 'They are in strictness to be deemed properties only of the act, or other event, by which such pleasure or pain has been produced; and accordingly only to be taken into the account of the tendency of such act or such event. ${ }^{30}$ Fecundity and purity must be taken into account even if the action is a 'self-regarding' action that affects only the agent. To measure fecundity, the likelihood that the pleasure or pain that is directly and immediately produced by the action will be followed by other pleasures or pains respectively must be estimated. To measure purity, the likelihood that the pleasure or pain first produced by the action will not be followed by pains or pleasures respectively must be estimated. The total value of the pains can then be deducted from the total value of pleasures so as to estimate the tendency of the action to yield net pleasure or net pain to the agent as the case may be. For Bentham, it seems, competent agents should be free to judge whether they should take a self-regarding action and to decide which of their possible self-regarding actions is best for promoting their own interests.

Extent (in addition to fecundity and purity) must be taken into account if the action, whether by a private individual or by a government 
agent, is a social or 'extra-regarding' action that affects some number of other people by causing them, or those (including non-human sentient creatures) with whom they sympathize, to experience physical sensations of pleasure or pain. Bentham prescribes that such actions should be selected so as to promote the greatest possible degree of general happiness. ${ }^{41}$ Although I cannot argue the point here, he seems to recommend that democratic majorities or their representatives should have the authority to estimate the relevant sum totals of pleasures and pains for the community, and to take whatever social actions (including enacting laws, issuing judicial orders and so forth) are deemed best by them to promote the total collective pleasure net of total collective pain in light of the fact that multiple self-interested people are jointly affected by the measures. ${ }^{42}$ Notice that an action considered to be the best of all feasible social actions for the community can in some situations be an action that produces net collective pain or unhappiness: there is no possible alternative action that results in net collective pleasure.

The upshot is that Bentham does not recognize higher kinds of pleasant feelings that are intrinsically superior as pleasure to lower kinds, regardless of quantity. For him, pleasant feelings, including relief from pain, are homogeneous across their sources such that equal quantities of pleasure are always of equal value. While it can vary in quantity, the quantity of this homogeneous pleasant feeling experienced by any individual from any source can be calculated by considering the four 'qualitative' dimensions of quantity as he recommends. The hedonistic tendency of any action or event can also be estimated by considering the remaining three dimensions of quantity as well. ${ }^{43}$

In contrast, Mill does recognize higher kinds of pleasant feelings that are superior in quality as pleasure to lower kinds of pleasant feelings. This is not the place to discuss in detail his doctrine of higher pleasures. ${ }^{44}$ But he makes clear that by superiority in quality he means unlimited or infinite superiority: a higher kind of pleasant feeling is intrinsically more valuable as pleasure than a lower kind, irrespective of quantity. The test of quality in this sense is the judgement of most if not all people who are competently acquainted with both kinds of pleasures. Such people have cultivated the higher mental faculties required to experience the higher kind. Since human nature is capable of experiencing only finite amounts of any kind of pleasure, the lower pleasure, however large in quantity, can never be equal in value to the higher pleasure, however small in quantity.

The crucial point for our present purposes is that, for Mill, moral and aesthetic kinds of pleasures are superior in quality to selfish and base kinds. People whose characters are predominantly selfish and miserable 
are not competent judges of these higher kinds of pleasures. Rather, competent judges of their quality must have developed moral and noble characters in which the higher mental faculties are cultivated and strengthened through habitual exercise. For most if not all of these individuals, as opposed to the predominantly selfish, the intensity of moral and aesthetic pleasures is raised to such a pitch that they are superior in quality to competing kinds of pleasures. ${ }^{45}$

Mill suggests that the kind of pleasant feeling that is a property of the moral sentiments, of which the sentiment of justice is the most important and sets the tone for the others - such as the sentiment of charity or kindness - is superior in quality as pleasure to any competing kinds of pleasures. ${ }^{46}$ This higher moral kind of pleasure, a feeling of security, grows up around the idea of justice understood as a system of equal rights and duties distributed and sanctioned by a fundamental social code. The code and the political system that facilitate its construction and enforcement are the only source of this pleasant feeling of security. Security, he says, depends on the continuous 'active play' of the institutional 'machinery' of justice. ${ }^{47}$ Most, if not all, individuals who have cultivated their higher faculties will feel that this moral kind of pleasure is superior in quality to any competing selfish kinds, Mill argues. Such highly developed moral agents are competently acquainted with both kinds since the development of a moral character involves progressing beyond the selfish characters typical of uncultivated humans in civil societies. For most of these committed moral agents, the pleasant feelings of security are 'so much more intense than those concerned in any of the more common cases of utility, that the difference in degree (as is often the case in psychology) becomes a real difference in kind'. ${ }^{48}$ The claim we have on others to cooperate 'in making safe for us the very groundwork of our existence' assumes for these people a virtually sacred importance: 'The claim assumes that character of absoluteness, that apparent infinity, and incommensurability with all other considerations, which constitute the distinction between the feeling of right and wrong and that of ordinary expediency and inexpediency. ${ }^{49}$

A key implication is the absolute importance of reasonable social codes of justice within Mill's extraordinary hedonistic utilitarianism. In my view, his utilitarianism is concerned only to aggregate over individuals' various preferences that rank alternative rules which are the possible sources of security. An optimal social code of equal rights and duties is gradually constructed and enforced by suitably competent participants in a democratic decision process. Individuals are free from coercion to pursue any kinds of pleasures (besides security) so long as they act in accordance 
with their recognized rights and duties as the code is established under this process. For general security to be maximized, equal rights and duties of a specific content must be extended impartially to all competent adult members of society and not only to some smaller peer group within society. ${ }^{50}$

In principle, the construction of an optimal social code of justice requires that participants in the democratic decision process should have developed their higher mental faculties. These include their capacities to sympathize impartially with other people and even with other species of animals, to construct and obey reasonable social rules of justice and morality designed to protect any human or other sentient creature from suffering harms that ought to be considered wrongs, to direct resentment and punishment against those who intentionally, knowingly, recklessly or negligently break the rules, and so on. But civil societies cannot wait for this social development process to be completed before establishing a social code of justice, even though any code selected in the meantime is virtually certain to be non-optimal. Mill, unlike Bentham, argues that as long as many if not most people remain predominantly selfish, the democratic decision process must include a liberal system of counter-majoritarian checks and balances designed to discourage the majority oppression of minorities and to inject more expertise into majority decisions. ${ }^{51}$

Another key feature of Mill's doctrine as interpreted follows from the fact that individuals are free to act in pursuit of any kinds of pleasures as long as they act in accord with their recognized rights and duties under the established code of justice. In particular, if genuine aesthetic pleasure does not compete with the moral pleasure of security and is even superior in quality to it, virtuous utilitarian martyrs are free to sacrifice their own lives to avoid the kind of aesthetic suffering that they expect to feel, and cannot tolerate, if they do not promote the general happiness by saving innocent others from severe harm, including death at the hands of third parties or natural forces. Most of us may be incapable of such supererogatory actions, and yet we can appreciate their beauty and sublimity. ${ }^{52}$

\section{Socrates dissatisfied}

To appreciate how the claim that it is better to be Socrates dissatisfied can be compatible with hedonism, it is essential to take seriously Mill's argument that there are higher pleasures whose quality or intrinsic tone is superior to that of lower pleasures, regardless of quantity, and that people who are competently acquainted with both kinds of pleasures recognize this qualitative difference and prefer the higher pleasure, 'even 
though knowing it to be attended with a greater amount of discontent'. ${ }^{53}$ The argument has no logical connection to Stoicism. Nor can Stoicism per se justify Mill's further claims: namely, that a noble individual who appreciates and seeks the higher pleasures will always fulfil his/her moral duties when it is feasible to do so; and that such a person may also take admirable supererogatory actions to promote the greater happiness of others even at the expense of his/her own life. Again, these further claims depend on Mill's argument that there are heterogeneous kinds of pleasant feelings such that higher kinds are superior in quality to lower kinds, regardless of amount. Mill never embraces the Stoic principle that 'pain is no evil, and pleasure no good'.

This is not to say that the elements of Stoicism identified by Rosen exerted no influence whatsoever on Mill's thinking. As a hedonist, however, Mill must provide a hedonistic argument to explain why an individual who is ultimately motivated by pleasure is moved by 'Stoic themes, such as a love of liberty, independence, and a sense of dignity'. ${ }^{54}$ The requisite hedonistic argument is supplied by the higher pleasures doctrine.

\section{Voluntary personal sacrifices}

If cultivated individuals who are competently acquainted with selfish pleasures as well as with the pleasant feelings that are properties of the moral sentiments always prefer in cases of conflict the moral pleasures, regardless of quantity, then hedonism supports the claim that such people will always fulfil their moral duties whenever feasible, even when doing so is contrary to self-interest. Such individuals have developed a powerful will to do right, with disinterested demands always overriding any competing selfish desires. In other words, they have become moral agents with a powerful conscience. They may be said to have acquired a sense of moral dignity. For any such moral agent, the moral kind of pleasure always outweighs any amount of selfish discontent and inconvenience that may result from fulfilling his/her duties to others. There is no suggestion that the selfish pains are not evils. But, for moral agents, the evils are always outweighed by the moral pleasure, including security from moral pain afforded by doing one's duty. In contrast, selfish individuals, who take immoral actions because they have not developed a powerful conscience that overrides their selfish desires in cases of conflict, know only one side of the question. They must cultivate their higher mental faculties before they can give a competent judgement as to whether moral pleasures are superior in quality to selfish ones. 
Now consider a possible hedonistic account of a noble person's supererogatory choice to sacrifice his/her own life to promote the greater happiness of others. Such a person may take a higher aesthetic kind of pleasure, in no way incompatible with the moral pleasure of fulfilling his/her duties to others, in living up to a surpassing ideal of personal honour and dignity that requires giving up his/her life when there is no other way to prevent innocents from losing their lives at the hands of third parties or natural forces. This utilitarian saint makes the ultimate sacrifice so as to avoid the acute personal suffering that s/he knows would ruin his/ her life anyway, and would result from a failure to uphold his/her honour and dignity under these tragic conditions.

Notice that this hero's voluntary sacrifice implies that his/her aesthetic pleasure, including exemption from suffering, exceeds any amount of competing pleasure that the person expects to feel in his/her remaining lifetime. Strictly speaking, s/he is not sacrificing his/her own happiness. Rather, the individual has a sublime idea of what personal happiness consists in. This person is so devoted to others as to be willing to give up his/her own life, although there is no duty to do so. Most of us, however, including committed moral agents as well as predominantly selfish ones, are likely to say that the person has sacrificed his/her personal happiness to promote the greater good of others.

Three further points may help to clarify this Millian hedonistic account of what motivates the cultivated individual to always voluntarily fulfil his/her moral duties and perhaps even to go beyond duty by sacrificing his/her life to promote greater happiness for others. First, it cannot be argued consistently with hedonism that the individual is motivated by a sum total of collective happiness that neither s/he nor anyone else actually experiences or feels. To hold otherwise is just a way of circumventing hedonism.

Second, Mill explains how any competent individual who seeks pleasure can come through experience to desire virtue for its own sake. 'Happiness is not an abstract idea, but a concrete whole,' he insists, and its concrete parts, such as fame, power, money and virtue, which are originally indifferent except as means to pleasure and exemption from pain, become desired for their own sake only once they are desired as a part of happiness:

And the utilitarian standard sanctions and approves their being so. Life would be a poor thing, very ill provided with sources of happiness, if there were not this provision of nature, by which things 
originally indifferent, but conducive to, or otherwise associated with, the satisfaction of our primitive desires [for food, shelter, sex, liberty, and so on], become in themselves sources of pleasure more valuable than the primitive pleasures, both in permanency, in the space of human existence that they are capable of covering, and even in intensity. ${ }^{55}$

Virtue is a very special 'good of this description', he emphasizes, in that it facilitates the attainment of many pleasures not only by ourselves but also by the other members of society, so that it can become strongly associated with both personal happiness and general happiness. Utilitarianism prescribes the cultivation of this association so as to generate a highly intense desire for virtue that will 'surpass in strength all other desires' in noble characters:

There was no original desire of [virtue], or motive to it, save its conduciveness to pleasure, and especially to protection from pain. But through the association thus formed, it may be felt as a good in itself ...; and with this difference between it and the love of money, of power, or of fame, that all of these may, and often do, render the individual noxious to the other members of the society to which he belongs, whereas there is nothing which makes him so much a blessing to them as the cultivation of the disinterested love of virtue. And consequently, the utilitarian standard, while it tolerates and approves those other acquired desires, up to the point beyond which they would be more injurious to the general happiness than promotive of it, enjoins and requires the cultivation of the love of virtue up to the greatest strength possible, as being above all things important to the general happiness. ${ }^{56}$

The desire for moral virtue can and should be cultivated to a point where the moral kind of pleasure, including exemption from guilt and remorse, associated with fulfilling one's duties to others whenever feasible, is felt as superior in quality to competing kinds, regardless of quantity. So too the desire for aesthetic virtue can permissibly be cultivated, consistent with moral duty, to a sublime point where an aesthetic kind of pleasure, including relief from dishonour and suffering, associated with taking supererogatory actions to promote greater happiness for others, is felt by utilitarian heroes or martyrs as superior in quality even to moral pleasures alone. 
Mill makes it clear in the course of his hedonistic explanation of spontaneous virtue that he does not rely on the Stoic view that 'pain is no evil, and pleasure no good'. As he emphasizes:

Those who desire virtue for its own sake, desire it either because the consciousness of it is a pleasure, or the consciousness of being without it is a pain, or for both reasons united; as in truth the pleasure and pain seldom exist separately, but almost always together, the same person feeling pleasure in the degree of virtue attained, and pain in not having attained more. If one of these gave him no pleasure, and the other no pain, he would not love or desire virtue [for its own sake as a part of his happiness]. ${ }^{57}$

Third, certain nuances are involved in Mill's claim that his enlarged hedonistic utilitarianism makes room for martyrs who sacrifice even their lives to promote the greater happiness of others. For example, should a noble individual really sacrifice his/her life to save those of a large group of narrowly selfish individuals who are incapable of feeling guilt for violating others' moral rights or of feeling gratitude for a supererogatory action that is likely to strike them as insane? If my reading is correct, it seems that Mill must concede that a person of noble character, who appreciates that moral and aesthetic pleasures are more desirable as pleasures than selfish pleasures, regardless of quantity, should not make such a sacrifice to promote the purely selfish happiness of others, regardless of how much aggregate selfish pleasure including relief from pain can be promoted by that sacrifice.

Much more needs to be said to elucidate Mill's hedonistic conception of human happiness. He clearly prescribes that competent individuals can and should cultivate their higher faculties so as to pursue a life comprised of higher moral and aesthetic pleasures: 'According to the Greatest Happiness Principle,' he says, 'the ultimate end, with reference to and for the sake of which all other things are desirable (whether we are considering our own good or that of other people), is an existence exempt as far as possible from pain, and as rich as possible in enjoyments, both in point of quantity and quality. ${ }^{58}$ In other words, happiness approaches as nearly as possible what he calls in On Liberty a 'Greek ideal' of self-development, that is, a noble personal character or individuality. ${ }^{59}$ Unfortunately, tragic situations can arise in which innocent individuals are confronted with grave harms from unjust people or natural 
calamities. True, cultivated people voluntarily recognize their moral duties to provide reasonable help, but such duties do not demand that they sacrifice their own lives. Even so, Mill's hedonism accommodates his claim that a saintly individual can freely take supererogatory actions by waiving his/her moral rights, including the right to life, to promote the happiness of others in these situations. But nobody, he admits, can legitimately be forced to take such sublime actions. The use of force would be immoral since it would violate the individual's moral rights, which by assumption have not been waived. Given that there is not a moral duty to waive one's rights to save others or safeguard their rights, does it follow that, for Mill, there is not a moral duty to maximize general happiness? Not necessarily, because people are not morally required to be saints, and the failure to take a sublime saintly action is not wrongful. People who fail to take such an action do not themselves inflict a moral kind of suffering on others, whereas forcing them to act does inflict the moral kind of pain on them, and inflicting even a bit of moral suffering can never be justified as a way to prevent any amount of non-moral pain, however large.

Other questions of interpretation surround Mill's conception of happiness and its implications for whether he is properly regarded as some unusual form of act utilitarian. For example, similar questions arise in connection with his absolute ban on coercive interference with selfregarding conduct. ${ }^{60}$ But I cannot add here to these brief remarks relating to his idea of happiness and the form of his utilitarianism.

\section{Notes}

1. According to Rosen: 'The link between utilitarianism and Epicureanism was strong in Hume, Smith, Helvetius, Paley, and Bentham, and it was arguably even stronger in Mill': Frederick Rosen, Classical Utilitarianism from Hume to Mill (London: Routledge, 2003), 172. For further discussion, see 13-206.

2. The shared commitment to hedonism must not be taken to imply that Epicureanism and classical utilitarianism are identical or even similar doctrines. For example, Mill identifies Bentham's inductive 'method of detail', which he greatly admires, as a central feature of their (different versions of) utilitarianism not found in Epicureanism: 'The application of a real inductive philosophy to the problems of ethics, is as unknown to the Epicurean moralists as to any of the other schools [before Bentham] ... Bentham certainly did not learn his sifting and anatomizing method [of detail] from them' (J. S. Mill, 'Bentham', in Collected Works of J. S. Mill [CW], ed. John M. Robson, Vol. X [London and Toronto: Routledge and University of Toronto Press, 1969], 203-59, citation at 87).

3. J. S. Mill, Utilitarianism, CW, X, 176; quoted by Rosen, Classical Utilitarianism, 181.

4. Rosen, Classical Utilitarianism, 182

5. Rosen, Classical Utilitarianism, 182.

6. Rosen, Classical Utilitarianism, 183.

7. Rosen, Classical Utilitarianism, 183.

8. For Mill's critique of Carlyle's approach, see, especially, Mill, Utilitarianism, CW, X, 214-19.

9. See J. S. Mill, 'Whewell on Moral Philosophy', CW, X, 175-9. 
10. Rosen, Classical Utilitarianism, 182-3.

11. Henry Sidgwick, Outlines of the History of Ethics (Indianapolis: Hackett, 1988), 244, original emphasis.

12. Mill, 'Whewell on Moral Philosophy', $C W, \mathrm{X}, 174-5$; and Mill, 'Bentham', $C W, \mathrm{X}, 98-9$.

13. Rosen, Classical Utilitarianism, 52; quoting Jeremy Bentham, An Introduction to the Principles of Morals and Legislation, eds. James Burns and Frederick Rosen (Oxford: Oxford University Press, 1996), 13.

14. Mill, 'Bentham', $C W, \mathrm{X}, 97$.

15. Mill, 'Nature', $C W, \mathrm{X}, 394-5$.

16. Mill, 'Bentham', $C W, \mathrm{X}, 97$.

17. Mill, 'Bentham', $C W, \mathrm{X}, 97$.

18. Mill, 'Bentham', $C W, \mathrm{X}, 94$. This is not to say that Bentham recognizes no motives other than self-interest and sympathy or antipathy towards other sentient beings. As Mill remarks, Bentham acknowledges a wide variety of other motives in this or that corner of his writings (956). But 'no conclusions are ever founded on the acknowledgment' (96). None of these motives 'are thought worthy of a place among the "Springs of Action"' (96).

19. As quoted from the 1842 edition of the Constitutional Code by Frederick Schauer in The Force of Law (Cambridge: Harvard University Press, 2015), 14, his emphasis omitted.

20. Bentham, Introduction to the Principles, 34, original emphasis.

21. Bentham, Introduction to the Principles, 11.

22. Bentham, Introduction to the Principles, 37, original emphasis.

23. Mill, 'Bentham', $C W, \mathrm{X}, 95$, original emphasis.

24. Mill, 'Bentham', $C W, \mathrm{X}, 95-6$, original emphasis.

25. Mill remarks that it would be 'most unjust to Bentham to surmise ... that this picture of human nature was copied from himself' (Mill, 'Bentham', $C W, \mathrm{X}, 96$ ). He goes on to stress that 'a noble sense of morality, and especially of justice, guides and pervades [all of Bentham's speculations]'. Bentham 'confounded all disinterested feelings which he found in himself, with the desire of general happiness', Mill says, because 'these feelings always acted in the same direction [as the desire]'.

26. Mill, 'Bentham', $C W, \mathrm{X}, 96$.

27. Bentham, Introduction to the Principles, 13, 40.

28. Bentham emphasizes that individuals have different sensibilities to particular pleasures and to particular pains. See Bentham, Introduction to the Principles, 51-76.

29. Rosen, Classical Utilitarianism, 49, referring to Bentham's Introduction to the Principles, 42-50.

30. Rosen, Classical Utilitarianism, 49.

31. Rosen, Classical Utilitarianism, 177; Bentham, Introduction to the Principles, 42-50.

32. Rosen, Classical Utilitarianism, 17.

33. Rosen argues that an individual may reveal an unstable preference for one source of pleasure over another: 'Such a preference might vary from moment to moment within the person expressing the preference' (Classical Utilitarianism, 177). But Bentham can accept that competent individuals have different ideas of their self-interest that may change over time. There is no reason to believe that he thinks rationality requires all competent egoists to always get more pleasure from their skills than from their memories, for example, or from eating, more than from contemplation.

34. Rosen, Classical Utilitarianism, 177, referring to Bentham, Introduction to the Principles, 38-41.

35. Rosen, Classical Utilitarianism, 177.

36. Rosen, Classical Utilitarianism, 178.

37. Bentham, Introduction to the Principles, 38.

38. Bentham, Introduction to the Principles, 38, original emphasis.

39. C. I. Lewis, among others, insists that 'this dimension of propinquity' should be struck out from the calculation of quantity of pleasure or good: 'the man who should deliberately sacrifice distant goods to near ones, would by that fact fail to achieve as good a life as he might upon the whole; and the greater weight he gives to nearer goods over more distant ones, the greater will be his eventual loss' (C.I. Lewis, An Analysis of Knowledge \& Valuation [LaSalle, IL: Open Court, 1946], 493). More generally, Lewis rejects hedonism and the Benthamite utilitarian calculus: 'Life, or any stretch of living, is not an aggregate of separate moments' (Analysis of Knowledge, 494).

40. Bentham, Introduction to the Principles, 39. 
41. For a sketch of the process that he prescribes to estimate the general tendency of any social action to promote the collective happiness of any given number of individuals, see Bentham's Introduction to the Principles, 40-1. He allows that: 'It is not to be expected that this process should be strictly pursued previously to every moral judgment, or to every legislative or judicial operation' (40).

42. Bentham is concerned to make legislators and other public officials as responsive as possible to popular majorities. For an important discussion, see Frederick Rosen, Jeremy Bentham and Representative Government: A Study of the Constitutional Code (Oxford: Oxford University Press, 1983).

43. I cannot discuss all of Bentham's examples cited by Rosen to bolster the argument that, for Bentham, there are severe limits to the quantitative evaluation of pleasures and actions. But in the case of the evaluation of a landed estate, described in Bentham's Introduction to the Principles, 40-1, and cited by Rosen in Classical Utilitarianism, 178, it seems clear that Bentham is merely explaining why intensity, fecundity and purity of pleasures are not reflected in the competitive market value of the estate. The market value is given before those three dimensions of quantity can be measured for prospective buyers. There is no suggestion that the three dimensions cannot in principle be estimated ex post facto, independently of the market value. Notice that Bentham does not refer to extent in this context, a sign of his awareness of the difference between a market evaluation and a utilitarian social evaluation of the estate.

44. For a more detailed discussion, see Jonathan Riley, 'Different Kinds of Pleasures', in Mill's System of Logic: A Critical Guide, ed. Antis Loizides (London: Routledge, 2014), 170-91.

45. A lower pleasure can never become so intense that it is transformed into a higher pleasure. The lower pleasure's intensity remains finite whereas an unlimited gulf separates the two kinds of pleasure. The higher pleasure's superior quality means that it is infinitely more intense than the lower pleasure. Mill claims that the superior quality is a chemical product of the higher pleasure's multiple ingredients, which include lower pleasures, but I cannot discuss this issue further here.

46. For Mill's analysis of the ingredients of the moral sentiment of justice and the kind of pleasant feeling including relief from suffering that in his view is inseparably associated with it, see Mill, Utilitarianism, 246-51, and also Jonathan Riley, 'Happiness and the Moral Sentiment of Justice', in Mill on Justice, ed. Leonard Katz (London: Palgrave Macmillan, 2012), 158-83.

47. Mill, Utilitarianism, CW, X, 251.

48. Mill, Utilitarianism, $C W, \mathrm{X}, 251$

49. Mill, Utilitarianism, $C W, \mathrm{X}, 251$. The qualitative superiority of the moral kind of pleasure may be recognized even by many individuals who have progressed beyond narrow selfishness to some extent but who remain aware that their desire to do right for its own sake is (to their regret) often too weak to override their selfish desires. Such individuals cannot always be relied upon to voluntarily comply with reasonable moral rules so that external sanctions continue to be needed to make them do right.

50. A right that Mill insists must be included in any civil society's code of justice is the right of absolute self-regarding liberty, defended in his On Liberty. See Jonathan Riley, Mill's On Liberty (London: Routledge, 2015). Mill was apparently influenced to some extent by Bentham's defence of self-regarding liberty. But Bentham does not speak of a moral right, and associates self-regarding conduct with predominantly selfish motives that might need to be regulated by external sanctions in some situations. Mill stresses that a moral right of complete self-regarding liberty has a utilitarian foundation, whatever the motives for taking self-regarding actions.

51. For further discussion of the system of checks and balances recommended by Mill, see Jonathan Riley, 'Mill's Neo-Athenian Model of Liberal Democracy', in J. S. Mill's Political Thought: A Bicentennial Reassessment, eds. Nadia Urbinati and Alex Zakaras (Cambridge and New York: Cambridge University Press, 2007), 221-49.

52. Such supererogatory actions may sometimes be self-regarding actions that do not cause non-consensual harm to others. But not always. See Jonathan Riley, 'Optimal Moral Rules and Supererogatory Acts', in John Stuart Mill and the Art of Life: A Critical Reader, eds. Ben Eggleston, Dale Miller and David Weinstein (Oxford: Oxford University Press, 2010), 183-229.

53. Mill, 'Bentham', $C W, \mathrm{X}, 211$.

54. Mill, Classical Utilitarianism, CW, X, 182.

55. Mill, Utilitarianism, CW, X, 236.

56. Mill, Utilitarianism, $C W, \mathrm{X}, 236-7$. 
57. Mill, Utilitarianism, CW, X, 237. Mill's remarks as outlined need to be supplemented by his recognition that 'will [volition] is a different thing from desire' and that, as a result, 'we may will from habit what we no longer desire for itself, or desire only because we will it' (238). But his recognition of the power of habit does not affect my argument. As he says: 'It is not the less true that will, in the beginning, is entirely produced by desire; including in that term the repelling influence of pain as well as the attractive one of pleasure' (238). Moreover, there is nothing intrinsically desirable about habits of willing per se.

58. Mill, Utilitarianism, $C W, \mathrm{X}, 214$.

59. For further discussion, see Jonathan Riley, 'Mill's Greek Ideal of Individuality', in John Stuart Mill: A British Socrates, eds. K. N. Demetriou and Antis Loizides (London: Palgrave Macmillan, 2013), 97-125; and Riley, Mill's On Liberty.

60. See Jonathan Riley, 'Mill's Absolute Ban on Paternalism', in Handbook of the Philosophy of Paternalism, eds. Kalle Grill and Jason Hanna (London: Routledge, 2018), 153-69.

\section{Bibliography}

Bentham, Jeremy. An Introduction to the Principles of Morals and Legislation. Edited by James Burns and Frederick Rosen. Oxford: Oxford University Press, 1996.

Lewis, C. I. An Analysis of Knowledge \& Valuation. LaSalle, IL: Open Court, 1946.

Mill, John Stuart. 'Bentham'. In Collected Works of J. S. Mill [CW], edited by John M. Robson, Vol. X, 75-115. London and Toronto: Routledge and University of Toronto Press, 1969.

Mill, John Stuart. 'Nature'. CW, X, 373-402.

Mill, John Stuart. Utilitarianism. CW, X, 203-59.

Mill, John Stuart. 'Whewell on Moral Philosophy', CW, X, 165-201.

Riley, Jonathan. 'Different Kinds of Pleasures'. In Mill's System of Logic: A Critical Guide, edited by Antis Loizides, 170-91. London: Routledge, 2014.

Riley, Jonathan. 'Happiness and the Moral Sentiment of Justice'. In Mill on Justice, edited by Leonard Kahn, 158-83. London: Palgrave Macmillan, 2012.

Riley, Jonathan. 'Mill's Absolute Ban on Paternalism'. In Handbook of the Philosophy of Paternalism, edited by Kalle Grill and Jason Hanna, 153-69. London: Routledge, 2018.

Riley, Jonathan. 'Mill's Greek Ideal of Individuality'. In John Stuart Mill: A British Socrates, edited by K. N. Demetriou and Antis Loizides, 97-125. London: Palgrave Macmillan, 2013.

Riley, Jonathan. 'Mill's Neo-Athenian Model of Liberal Democracy'. In J. S. Mill's Political Thought: A Bicentennial Reassessment, edited by Nadia Urbinati and Alex Zakaras, 221-49. Cambridge and New York: Cambridge University Press, 2007.

Riley, Jonathan. Mill's On Liberty. London: Routledge, 2015.

Riley, Jonathan. 'Optimal Moral Rules and Supererogatory Acts'. In John Stuart Mill and the Art of Life: A Critical Reader, edited by Ben Eggleston, Dale Miller and David Weinstein, 183-229. Oxford: Oxford University Press, 2010.

Rosen, Frederick. Classical Utilitarianism from Hume to Mill. London: Routledge, 2003.

Rosen, Frederick. Jeremy Bentham and Representative Government: A Study of the Constitutional Code. Oxford: Oxford University Press, 1983.

Schauer, Frederick. The Force of Law. Cambridge: Harvard University Press, 2015.

Sidgwick, Henry. Outlines of the History of Ethics. Indianapolis: Hackett, 1988. 


\section{1}

\section{Individualist and Totalizing Ethical Thinking in Mill's Utilitarianism}

John Charvet

\section{Introductory remarks}

This essay is a piece of ethical theorizing carried on through an examination of what Mill has to say about the relations of utility, equality and morality in his Utilitarianism. Since this approach to the study of Mill's work is certainly not in the spirit of Professor Rosen's important new study of Mill's ideas and may appear to be expressly rejected by him, I begin with a few introductory remarks regarding my method.

In his new book, Professor Rosen says that for students of Mill's thought to concentrate on his three major essays - OnLiberty, Utilitarianism and Considerations - cannot by itself provide satisfactory accounts of the issues discussed by Mill in these works. This is because to do so ignores what Mill has to say in his System of Logic and his Principles of Economics on the ends and methods of the scientific study of human well-being. ${ }^{1}$ Rosen claims that 'we should be approaching On Liberty (and many of his other essays) as an attempt to explore the causal conditions ... for the development of active character and the associated evolving possibilities for human flourishing in the widest possible sense'. ${ }^{2}$ Nevertheless, Rosen acknowledges that Mill is committed to the belief, arrived at through the exercise of the 'art of life', that, in Mill's words quoted by Rosen, 'the general principle to which all rules of conduct ought to conform, and the test by which they should be tried, is that of conduciveness to the happiness of mankind ... that the promotion of happiness is the ultimate principle of teleology'. ${ }^{3}$ So Rosen is not denying that for Mill the principle of utility is 
the ultimate standard by which to judge human practices. His claim is that 'the content of happiness is not especially determinate - it is not a standard against which we can measure sets of relationships in detail - allowing us to make maximizing conclusion'. ${ }^{4}$ This is because happiness as the end is always open to further and deeper exploration, and the content of what best satisfies the end is evolving over time and according to changes in our understanding of it. In particular, the science of ethology, discussed in his System of Logic, is crucial for the production of the empirical evidence to support judgements that such and such social arrangements best satisfy the end. Furthermore, these judgements, according to Rosen's Mill, will not be universal prescriptions but relative to time and place and national character.

I do not think that my method and assumptions in the following essay conflict with Rosen's broad conclusions about the character and content of Mill's work. It is common ground between us that Mill's ethical thought has as its foundation the greatest happiness principle. Rosen's contribution to an understanding of that principle is to show how flexible, relative and, consequently, indeterminate Mill envisaged its application to be. With regard to the deepening and evolving sense of the content of that principle, Mill's essays On Liberty and Utilitarianism have much to say. They show how virtue and individuality can come to be understood as part of the final end of happiness and hence pursued for their own sake and not as a means to happiness. With regard to a substantive sense of equality in Utilitarianism, Mill's claims are different. This sense of equality is, Mill believes, part of the very meaning of the greatest happiness principle. It is not a content that comes to be associated with happiness and then identified as part of the end. To understand the meaning and moral obligation of the greatest happiness principle is to recognize that this substantive equality is morally required.

One of my claims in the following essay is that the movement of Mill's thought towards his conclusion as to the egalitarian meaning of the greatest happiness principle is confused and mistaken. This failure of Mill leaves the greatest happiness principle unprotected because it is unqualified, as a maximizing principle. Professor Rosen is, no doubt, right that the content of what is to be maximized is open to all of the qualifications he makes. However, my concern is primarily with the ethical status of a maximizing principle, such as the greatest happiness principle, rather more than with how its content is to be determined. I contrast maximizing, or what my title refers to as totalizing, principles with individualist ones. The latter do in fact introduce a strong equality principle in their foundations. That is why Mill's attempt and failure 
to attach such an egalitarian meaning to his foundational principle is of such interest to me. In the end, this essay is just a piece of ethical theorizing carried out with reference to Mill's Utilitarianism. I do not think that what it attributes to Mill or what criticisms it makes of Mill are incompatible with Professor Rosen's much broader and deeper understanding of Mill's thought. The essay makes no claims to characterize Mill's thinking in general. It is concerned only with Mill's attempt in Utilitarianism to analyse the meaning and justification of the utilitarian principle.

\section{The meaning of the terms}

By totalizing ethical thinking, I mean a conception of ethics that identifies the ethical claims of an individual in terms of his/her contribution to a larger good such as the good of the nation, the workers, humanity, the actualization of reason or the general happiness. An example of such totalizing ethics is Hastings Rashdall's view that the greater capacity for high culture of white men in the modern age may justify the sacrifice of the lower well-being of countless Chinese or Africans for the sake of the higher life of a much smaller number of white men (he was writing in 1924). The good on this view is the maximization of well-being understood in terms of quantity and quality of life. In this total, the higher life 'counts as intrinsically, in and for itself, more valuable than lower life'. ${ }^{5}$ One reason why Mill avoided making such an ethically unsound, and now hugely politically incorrect, claim, despite sharing Rashdall's views on higher and lower life, was because of his belief that everyone is capable of participating in the higher life. ${ }^{6}$

By individualist ethical thinking, I mean a conception of ethics that holds that a just order of society must aim at promoting and protecting the fundamental interests of each individual. This formulation should not be interpreted as being limited to a description of liberal individualist ethics. It is perfectly compatible with illiberal and hierarchical conceptions of a just social order. The classic example of an illiberal but individualist ethics is Plato's Republic. It satisfies my individualist ethical idea because Plato claims to show how his conception of a just society is in the best interests of each member of society. Its hierarchical order is the one best suited to enable each class of person to live a good life given their natural capacities. Rashdall rejects such a view. The higher life of white men may make no contribution to the life of the lower types. Indeed, it may require the sacrifice of the interests of the lower types so that the others may flourish. 
In my formulation of an individualist ethics, the ethical claims of individuals to have their fundamental interests respected in the social order does not oppose - at least potentially - the individual's interests to the good of the whole. From an ethical point of view, the good of the whole is to be arrived at through the order that promotes and protects the fundamental interests of each member. To be plausible, such an ethics requires the belief that the whole will flourish best through its ethical formation. In the Platonic tradition, this harmony between the interests of the individual members and the interests of the whole society is secured through its functionalist conception of the social order. The members of each class best secure their fundamental interests in the good life by fulfilling a social function that is appropriate to them and through which the good of the whole is achieved. ${ }^{7}$ In the liberal individualist tradition based on the equal status in the social order of each member, the good of the whole is arrived at by securing to each person the means whereby all can take responsibility for their individual and collective lives and achieve a greater well-being than they would achieve under a paternalist, hierarchical order.

It should be noted that this formulation of a liberal individualist ethics cannot be based on a foundational principle such as the claim that individuals are ends in themselves and beings of absolute worth. Such a foundational principle is the contrary of the totalizing ethical idea. Whereas the latter annihilates the independent ethical status of the individual, the 'Kantian' formula annihilates the independent ethical claims of the social whole. ${ }^{8}$ Obviously, any adequate ethics must align the two.

My conception of ethical individualism builds a kind of equality into the very idea of an ethical order. This is an equality of respect for the fundamental interests of each member of society. The argument in this paper is that Mill's conception of utilitarianism is initially expressed in totalizing terms but that he seeks to avoid the unacceptable implications of the totalizing idea through two strategies. One is by claiming that the required equality is contained in the utilitarian idea itself or is the inevitable product of the advance of civilization; the second is by distinguishing the foundational principle of utility from secondary or derivative principles and motivations. Neither succeeds. The failure of the latter covers well-trodden ground. The failure of the former is more interesting. It shows that Mill recognizes that utilitarian ethics is acceptable only if it incorporates the ethical individualist idea. But the two are not compatible. 


\section{Mill's attachment to the totalizing idea}

Mill's initial formulation of the principle of utility, or the greatest happiness principle, is clearly totalizing in form. The principle is said to be the foundation of morals and holds that actions are 'right in proportion as they tend to promote happiness, wrong as they tend to produce the reverse of happiness'. ${ }^{9}$ This happiness is not the agent's own happiness but the greatest amount of happiness altogether. ${ }^{10}$ In order to arrive at this total, the agent must be as strictly impartial between his/her own happiness and that of others as a disinterested and benevolent spectator. ${ }^{11}$ If you are trying to maximize a total and you are required to be indifferent to the distribution of the elements of the total between different individuals, you will in effect be treating the different individuals as different parts of one composite individual. A pain to individual $\mathrm{X}$ will then count only as a pain in part $\mathrm{X}$ of the composite individual $\mathrm{C}$ and may be compensated for by a greater pleasure to individual Y. ${ }^{12}$ However, this interpretation supposes that the impartial spectator is required to be indifferent to the distribution of pains and pleasures between people. If each individual had a basic right to a certain amount of pleasure - for instance, an equal amount - the impartiality condition would have to take that distributive entitlement into account. But at this point there is no mention in Mill of such a basic right.

In the above supposition, the good of $\mathrm{X}$ - his/her freedom from pain - is being sacrificed for the sake of a greater pleasure accruing to $Y$ and thus the achievement of a larger total surplus of pleasure over pain. That such a sacrifice is envisaged by Mill is made explicit in his discussion of the acceptability of self-sacrificial actions within the utilitarian philosophy. The state of the world may be such that what a utilitarian agent had most reason to do would be to renounce happiness for her/himself in order to serve the happiness of others. ${ }^{13}$ This renunciation of happiness would be justified by the good consequences for others and its conformity with the greatest happiness principle. The action would be the right one according to that principle. Indeed, Mill calls it an action of the highest virtue. Nevertheless, despite what he says later about virtuous motivation, here he wants the utilitarian agent to sacrifice his/her happiness, not for the sake of virtue, but for the sake of the gains to others.

It is true that Mill considers such a state of the world to be a bad one and views the advance of civilization as eliminating the conditions in which self-sacrifice is required by the utilitarian principle. This might 
suggest that Mill believes self-sacrifice to be bad over and above the reduction of happiness in the total sum; that it is bad in itself that anyone should have to sacrifice his/her happiness for others. On a strictly totalizing account of the situation, the only deplorable aspect would be that a greater total net happiness could have been achieved by eliminating poverty and other causes of unhappiness. But if self-sacrifice were bad in itself within a happiness-based philosophy, it would have to be so because it would involve the sacrifice of something such as an individual's basic right to a certain level of happiness, and again there is no suggestion here of such a right.

Mill says that the advance of civilization involves a move towards social equality and the harmonization of interests. His account of this progress towards equality and harmony is part of his argument regarding the sufficiency of the utilitarian sanction. It is the claim that the feeling of duty, which can come to be associated with the idea of the general happiness, is capable of being sufficiently strong to motivate the members of a society of utilitarians because of its connection with a powerful natural sentiment. These strong natural sentiments are the social feelings of mankind - by which he means the desire to be in unity with one's fellow creatures. Mill believes that the social state is so 'natural, necessary and habitual' that the individual doesn't normally think of her/himself as a separate entity but as a member of a social body. Only through an unusual effort of abstraction can a person think of her/himself as an independent individual.

Mill says that, except in the case of the relation between master and slave, the social state is impossible, other than on the basis of the consultation of everyone's interests. However, this formulation is compatible with the totalizing interpretation of the utility principle. In order to arrive at the greatest happiness, everyone's interests must be considered. But such consideration does not exclude the conclusion that, in order to achieve the greatest happiness, X's interests in happiness must be sacrificed for the sake of the greater benefit accruing to A, B and C.

Mill moves immediately from the requirement to consult everyone's interests to that of regarding them equally. His idea is that a society of equals must require that the members' interests be accorded equal consideration. While he recognizes that relations of inequality are to be found in most societies, he claims that in every society, everyone is obliged to live on terms of equality with some others (except for absolute monarchs) and in every age some advance is made towards a state in which it will be impossible to live on any other terms with anyone. History or civilization is, thus, moving in the direction of bringing about a 
society of equals. Unfortunately, this claim still doesn't exclude the totalizing interpretation. Everyone's interest must be counted and an equal weight given to each. But in calculating which social arrangement will produce the greatest sum of net pleasures, the possibility of overriding some people's interest in happiness for the sake of a greater gain in happiness to others is still not excluded. I do not doubt that by a society of equals, Mill had in mind one in which the social status and the condition of the members were more or less equal and that the possibility of overriding them was of no significance. However, what I am taking issue with here is not what sort of society Mill was expecting and hoping to ensue through the progress of civilization, but the adequacy of his understanding of the principle of utility as the ethical foundation of this progress. What I am claiming is that nothing he has said so far in explicating this principle effectively qualifies the totalizing interpretation of it.

Thus, although he says that, in this march towards equality, the developing sense of unity with one's fellows will lead people to be 'under a necessity of conceiving themselves as at least abstaining from all grosser injuries' - which suggests their recognition of some basic rights of a negative character - yet his conclusion as to the nature of the end state of this process is a striking formulation of the totalizing ethical idea. He says that:

in an improving state of the human mind, the influences are constantly on the increase, which tend to generate in each individual a feeling of unity with all the rest; which, if perfect, would make him never think of, or desire, any beneficial condition for himself, in the benefits of which they are not included. ${ }^{14}$

Normally, one would think that, given the diversity of things different people find pleasure in pursuing, a desirable state of the world would be one in which they have the freedom to cultivate their own interests without having to claim that all others must benefit from their activities. Usually, a person who enjoys watching football matches or performances of ballet does not think everyone else must also do so. A state of the world in which the contrary holds would amount to one in which each person saw her/himself as part of a larger composite person, such that a benefit to individual/part $\mathrm{X}$ would be a gain to the whole and so to the other individuals/parts because together they constitute a single ethical entity. Such is the attraction of the totalizing idea for Mill that he comes up with this formulation of an ideal future state of humanity even when he recognizes that the development of the appropriate feelings might 'interfere 
unduly with human freedom and individuality'. ${ }^{15}$ What, in my view, the member of a free society - in which individuals have rights to pursue their own interests, within definable limits, without regard to the consequences for others - should be able to think is that my freedom is a good for me as part of a general scheme of freedom that is also a good for all of the other participants.

It is relevant to note here that Mill's account of the progress of civilization towards the harmonization of interests is historical and psychological in character. It aims to show that civilization is actually moving in the direction required by the operation of the utilitarian principle and that motivationally it is possible for human beings to be moved to action by it. The account is not at this point an exploration of the ethical idea of the principle of utility as the foundation of morals. Yet his account throws light on what he thinks is involved in that idea. He believes that the principle of utility must incorporate, and that the movement of history is in the process of incorporating, an important notion of equality. But, so far he has not been able to formulate a conception of that equality that liberates it from the totalizing interpretation.

\section{Mill's account of the relation of equality and utility in chapter 5 of Utilitarianism}

In this chapter, Mill is concerned to show that although the sentiment of justice is distinctive among the moral sentiments through its strength and closeness of association with the individual's own well-being, these facts do not require us to think of justice as a principle independent of utility. Mill spends some time analysing the sentiment of justice because he thinks that therein lies the clue to the peculiar importance attached to the idea of justice as standard that leads thinkers to assert the claims of principles of justice over those of utility. The notion of justice is associated with a peculiarly strong natural sentiment, namely the natural feeling of retaliation or vengeance for harms done to us or to those with whom we identify our interests. But it is not clear that he needs this analysis. When he comes to distinguish the just from the expedient, he does not appeal to such a natural sentiment, but argues that justice is 'a name for certain classes of moral rule, which concern the essentials of human well-being more nearly, and are therefore of more absolute obligation, than any other rules for the guidance of life. ${ }^{16}$ These are rules that forbid human beings from hurting one another, including hurting them by wrongfully interfering with their freedom. They are, therefore, more vital to human 
well-being than rules for the best management of 'some department of human affairs'. Such rules are important not only because they prevent individuals from harming each other but because in so doing they constitute 'the main element in determining the whole of the social feelings of mankind. ${ }^{17}$ They preserve the peace without which 'everyone would see in everyone else an enemy, against whom he must be perpetually guarding himself'. ${ }^{18}$ Furthermore, for the above reasons, they are the rules that human beings have the most interest in impressing on each other and in demanding each other's compliance with them.

In effect, Mill is distinguishing the rules of justice from the rules of utility more generally on the grounds of their containing a far greater degree of utility for human beings than other rules. On this view, the principle of utility justifies secondary rules, some of which we come to call rules of justice because of their peculiar importance for human well-being and the peculiar obligation we attach to their observance. This is one way in which one might seek to introduce an individualist ethical principle into a utilitarian theory: in order to maximize human well-being, we need to ensure that everyone's fundamental interests are protected and promoted. I will be considering the adequacy of such a strategy in the next section. In the rest of this section, I will examine a quite different strategy of Mill's: his attempt to construe the principle of utility itself so as to include a strong principle of equality, not as a secondary rule, but in its very meaning.

He begins his account of the relation of equality and utility by treating equality as a corollary of the fundamental maxims of justice. Thus, 'it is a duty to do to each according to his deserts, returning good for good as well as repressing evil by evil', from which maxim he says that 'it necessarily follows that we should treat all equally well (when no higher duty forbids) who have deserved equally well of us, and that society should treat all equally well who have deserved equally well of it, that is, who have deserved equally well absolutely'. He claims that this formula is 'the highest abstract standard of social and distributive justice; towards which all institutions and the efforts of all virtuous citizens should be made in the utmost possible degree to converge. ${ }^{19}$

How this formula of equality would work out in terms of my individualist ethical principle would depend on what one believes about people's fundamental deserts. But in any case, since he has just denied that the standard of justice is independent of utility, this logical corollary of the maxims of justice would amount only to a corollary of 'secondary or derivative doctrines' ${ }^{20}$ Yet this suggestion is what he immediately denies. He says that 'this great moral duty rests upon a still deeper foundation, being 
a direct emanation from the first principle of morals', that it 'is involved in the very meaning of Utility, or the Greatest Happiness Principle'. ${ }^{21}$ His explanation of how this is so, however, is merely a reformulation of the totalizing interpretation of the principle of utility. 'That principle is a mere form of words without rational signification, unless one person's happiness supposed equal in degree (with the proper allowance made for kind), is counted for exactly as much as another's' and he goes on to quote Bentham's well-known dictum regarding the principle of utility, 'everybody to count for one and nobody for more than one'. ${ }^{22}$

The note Mill supplies to his introduction of Bentham's dictum, aimed at defending the principle of utility's adequacy as a sufficient guide to right against Herbert Spencer, illuminates the totalizing aspect of the above formulas. He says that the principle of utility, rather than presupposing, as Spencer claims, that everybody has an equal right to happiness, 'may be more correctly described as supposing that equal amounts of happiness are equally desirable, whether felt by the same or different persons'. This, he says, is not a premise necessary to support the principle of utility but the very principle itself. It shows, he goes on, that 'the truths of arithmetic are applicable to the valuation of happiness'. ${ }^{23}$ Recall that by a totalizing ethical principle, I mean one that identifies a person's fundamental ethical claims in terms of his/her contribution to a total, such as the general happiness, and that this understanding of ethics allows an overriding of some people's fundamental interests for the sake of a greater total. Such an overriding could be ethically acceptable only if, in calculating the total good, such as happiness, it doesn't fundamentally matter whether a certain stream of happiness or unhappiness accrues to person $\mathrm{X}$ or person Y. From the point of view of maximizing the total, $\mathrm{X}$ and $\mathrm{Y}$ are interchangeable. They are merely aspects of the composite person who is, so to speak, the owner of the totality of the experiences of his/her parts.

However, it is obvious from what Mill immediately goes on to say about the implications of the equality formulas he has just expressed, that he has no idea that they do not protect an individual's fundamental interest in happiness from being overridden in the above way. For after stating them, he continues thus:

the equal claim of everybody to happiness in the estimation of the moralist and of the legislator, involves an equal claim to all the means of happiness, except, insofar as the inevitable conditions of human life, and the general interest, in which that of every individual is included, set limits to the maxim. ${ }^{24}$ 
Effectively, Mill is supposing that there is no difference between the claim that equal amounts of happiness are equally desirable and the claim that everybody has an equal right to happiness and the means to happiness. He cannot see that the first is not essentially a claim about the rights of separate individuals but about streams of happiness wherever they may occur, while the second is essentially a claim that there are separate individuals and that each such individual has as much right to happiness as anyone else. It would seem to follow that if the equal distribution of happiness and the means to happiness had the effect of lowering the total amount of net happiness, nevertheless this reduction would be ethically right. In this case, Mill would be affirming an individualist ethical principle as contained in the very meaning of the principle of utility.

It might be argued that Mill's affirmation of an equal right to happiness and the means to happiness does not mean the same as having a right to equal happiness and equal means. All it involves is the claim that everyone equally has a right to some happiness but not necessarily an equal happiness. However, given that Mill immediately qualifies this equal right by allowing for justifying inequalities, it is obvious that his baseline equality is a substantive right to equal happiness from which departures may be justified.

Such departures are justified if they are required by the inevitable conditions of human life and the general interest. I take this qualification to involve the idea that, since some kind of political and legal order is necessary for the peaceful association from which everybody benefits, the inequalities that arise from such developments may be justified. The general interest, he says, includes everybody's interest. This could be given a totalizing interpretation: everybody's interest in their happiness is included in the calculation of the maximizing total. But in the immediate context of his affirmation of a basic equal right, the individualist understanding of the general interest seems more appropriate. On that view, the inequalities would be justified only if everybody gains.

My claim in this section is that Mill has come round to the idea that the principle of utility can and should be expressed in terms of an individualist ethics that guarantees to each person an equal right to have their fundamental interest in their happiness promoted and protected in the social order. My claim is also that Mill is mistaken in thinking that an unqualified greatest happiness principle is identical to the individualist principle. The former attaches no fundamental ethical significance to the distinction between persons; the latter makes that distinction the foundation of any satisfactory ethics. Does Mill's confusion on this point really matter? Can't we just say that Mill clearly approves of a social 
order constructed on individualist ethical lines and dismiss his tendency to accept totalizing formulations of the greatest happiness principle? It depends what we are interested in. If our concern is with the foundations of ethics, then Mill's confusions are clearly important.

\section{Mill's appeals to secondary or derivative principles}

Mill introduces the idea of secondary, derivative or subordinate ethical considerations at various points in his argument. They are designed to mitigate an interpretation of the greatest happiness principle that its critics seek to pin on its advocates. This is the totalizing interpretation. However, if Mill thought he had shown how the utility principle included in its very meaning the fundamentals of his ethical opponents' views, there would have been no need for him to seek to develop these indirect strategies. Such indirect strategies presuppose the correctness of the totalizing interpretation in the first instance and then seek to show how challenges to its supposed consequences can be defeated. This is another aspect of Mill's confusion on the foundations of ethics. In my discussion of these strategies, however, I shall ignore Mill's attempts to render them pointless, which I have covered in the previous section, and take them seriously as ways of avoiding the implications of a totalizing ethics.

His first move, however, is against critics of the utilitarian idea who think it involves too demanding an ethics. Mill represents them as claiming that utilitarianism requires ethical agents always to act from a motive of promoting the general interests of society. If the standard of right and wrong for an ethical agent is the effect of acts on the general happiness, then it is not an unnatural interpretation of that idea to believe that it requires such agents to be motivated to promote the general happiness. Whether one thinks that this interpretation should be rebutted because it mistakenly demands too exacting an ethical motivation of human beings or because it would lead them to pursue arrangements that are morally unacceptable, the reason for the objection is the same on both views: utilitarianism requires ethical agents always to be motivated by the desire to promote the greatest happiness.

Mill's rebuttal of this interpretation of the utilitarian ethic consists in distinguishing between utilitarianism as providing the standard of morality and as determining the best rules of action from the motive of agents in following the rules laid down by the standard. ${ }^{25}$ Clearly, someone has to be directly motivated by the maximizing utilitarian idea on this view in order for the best rules of action to be designed. But, once the 
rules are in place, the ordinary member of society need be motivated only by respect for the rules. The moral rules may thus satisfy in one way or another the claims of each individual to have his/her fundamental interests recognized in accordance with the ethical individualist idea and the ordinary human being may be motivated to comply with the rules solely from respect for such claims and without regard to the consequences of their particular acts. It is not very clear from Mill's account of this distinction whether the difference between totalizing utilitarian thinking and the motivations of common-sense morality is one that arises in each person at different times or involves a distinction between classes of person. Bernard Williams attributed the latter view to Sidgwick and pilloried it as the Government House morality of British colonial administrators. ${ }^{26} \mathrm{R}$. M. Hare calls the two types of ethical thinking archangelic and proletarian and thinks that each person can and should at different and appropriate times engage in each. ${ }^{27}$ The standard reasons why such utilitarians as Hare think that we should, for the most part, operate as proletarians in our moral thinking is that making a success of the archangelic standpoint requires less imperfect information about the consequences of particular acts than human beings normally possess and less morally weak and self-interested agents than human beings usually are.

There is clearly much to be said for some such distinction. Even ethical individualists usually recognize that, in some extreme circumstances, it may be necessary to act contrary to our ordinary moral obligations and lie, steal or kill the innocent in order to avoid a much greater evil. However, the difference, at this point, between the archangelic utilitarian and the ethical individualist is that the former is knowingly acting in accordance with his/her understanding of the most fundamental ethical principle while the ethical individualist knows that s/he is acting contrary to his/her fundamental ethical beliefs. The utilitarian archangel remains the ideal moral agent from a utilitarian perspective. But this is far from being the case for the ethical individualist. This claim needs explaining, which I will do in my final section. In the rest of this section I shall show, very briefly, that the other indirect strategies to which Mill appeals raise the same issue.

In Chapter 4 of Utilitarianism, in which Mill offers a proof of the greatest happiness principle, he begins by allowing that people desire other things as ends besides happiness. ${ }^{28}$ For instance, some people desire virtue or money for their own sake. Such things are not naturally ends, however. They are means to happiness in the first instance. Nevertheless, Mill claims that it is good that virtue should come to be desired for its own sake. Indeed, he says that: 
the mind is not in a right state, not in a state conformable to Utility, not in the state most conducive to the general happiness, unless it does love virtue ... as a thing desirable in itself, even though, in the individual instance, it should not produce other desirable consequences which it tends to produce, and on account of which it is held to be virtue. ${ }^{29}$

This passage strongly suggests that the endorsement of virtue as an end to be pursued for its own sake is an indirect strategy for maximizing utility. However, in accordance with his psychological hedonism, Mill holds that one cannot desire something as an end unless one comes to associate one's own happiness with the present enjoyment of that thing and one's unhappiness with its absence. Virtue, or whatever one comes to desire as an end, becomes part of how one understands happiness. So, one doesn't desire it as distinct from happiness. This line of argument suggests that desiring virtue for its own sake is not a means to maximizing utility but an essential part of the final end. Hence, it is not an indirect strategy. However, virtue for its own sake as part of happiness is only one's own happiness, not the general happiness, and virtue in this sense (common-sense morality) may come into conflict with what is required for the general happiness. At this point, the utilitarian ethical thinker should, if possible, adopt the archangelic standpoint, which conflicts with, yet necessarily trumps from a utilitarian perspective, the standpoint of virtue. It is true, as we have seen above, that Mill believes the progress of civilization will lead to a greater and greater alignment by each person of his/her happiness with the happiness of everyone else, but that very idea is the product of a totalizing imagination and is in itself absurdly unrealistic.

The upshot of this discussion of the status of virtue for Mill in the promotion of the greatest happiness is that it really only makes sense as an indirect strategy and that this strategy preserves the primacy of the archangelic ethical agent. In the final chapter of Utilitarianism, in which Mill discusses the relation of the rules of justice to the principle of utility, this primacy of the totalizing perspective of the archangel over the indirect strategy is quite explicit. The rules of justice, as we have seen, are the most important secondary principles for the achievement of the greatest happiness. They concern 'the essentials of human well-being more nearly ... than any other rules for the guidance of life'. However, the dictates of justice are many and conflicting and there is much difference of opinion among individuals in the same society and between societies as to how these conflicts should be ordered. 'From these confusions,' Mill says, 'there is no other mode of extrication than the utilitarian. ${ }^{30}$ In other 
words, we have to call in the archangel to resolve these disputes by providing a totalizing perspective on them.

\section{Some concluding thoughts on the relation between the individualist principle and the greatest happiness principle (PU)}

The usual criticism of indirect utilitarianism is that its strategy requires individuals to be motivated for the most part by non-utilitarian considerations: they should respect the rules of common-sense morality without regard to the consequences. Yet, at the same time they must hold themselves ready to adopt the totalizing perspective of the unqualified utilitarian agent. If this means that the ethical agent must be moved to act by both anti-utilitarian and pro-utilitarian commitments at the same time, then this is not a possible moral psychology. It is, of course, possible for an agent to follow rules from a utilitarian inspiration that if generally adopted would be likely to produce the greatest utility while overriding the rules when the principle of utility demands it. In that case, a certain amount of rule-following is incorporated into the judgements of the totalizing utilitarian agent. Rule and act utilitarianism become extensionally equivalent and the ethical motivations of the agent will be utilitarian throughout.

However, rather than follow that line of argument any further, I shall return to the point raised in the previous section: even the anti-utilitarian ethical individualist will need to recognize that on occasion it may be necessary to lie, to seize people's property or kill the innocent in order to avoid a greater evil. But the ethical individualist knows that such acts violate his/her ethical principles and need some special explanation and justification, while the utilitarian agent should be able to see them as part of normal ethical commitment. In what follows I shall sketch a way of understanding the ethical individualist position that throws a different light on the relation between the ethical principles and general utility. It is fundamental to this approach to see the principles as governing the choice of a basic structure of social institutions under which a collection of people commit themselves to associate, or in other words to interact in pursuit of their interests. Recall that in essence the ethical individualist position is the commitment to associate on terms that protect and promote the fundamental interests of each associate. This excludes only such totalizing proposals as Rashdall's willingness to sacrifice the happiness of untold numbers of Africans and Chinese for the higher life of 
a much smaller number of white men. It doesn't exclude the hierarchical, paternalistic and inegalitarian arrangements proposed by Plato and countless others.

Why are Rashdall's proposals unacceptable but not Plato's? Those whose happiness will be sacrificed to promote the well-being of some others under Rashdall's scheme are perfectly capable of understanding what is being proposed and can see that there is nothing in it for them, whereas under Plato's idea of a just republic, everyone is supposed to be the best off that they could be (except, possibly, the philosophers). But this answer presupposes a fundamental individualism. The basic unit to which an ethical scheme is accountable or has to be justified is the human individual. On Rashdall's view, it is some collective or abstract identity. So, it is justifiable to the individual losers if every individual's correct identity, including that of the losers, is a vehicle for this greater being. No human individual is properly understood as an end in itself but only as the means through which this higher life is actualized.

However, even on my Rawlsian suggestion as to how we should think of possible ethical principles - namely as the terms of association for individuals - a collectivity is presupposed. The individuals thinking about the terms on which they should associate cannot, of course, be sensibly understood as independent persons living in a state of nature outside society but must be conceived of as members already of an ongoing society who are reflecting on the ethical adequacy of their existing arrangements. They must already be committed to pursuing their individual goods in association as members of the same society bound by the same rules and institutions in order to pursue such an enquiry. In other words, they do not just have an individual identity whose good they are seeking but must also possess a collective identity as members of the society in question, whose (common) good is to be realized through the ethical principles that will protect and promote the fundamental interests of each associate. However, the difference between a totalizing conception of the relation between individual and collective good and an individualist one is that under the latter there must be some description of the individual's good as an inherently separate entity and the ethical principles must protect and promote this good, whereas under the former the good of the individual consists just in the extent to which s/he serves as a vehicle for the good of the collective entity.

On my individualist account, the ethical principles that protect individuals' interests are the terms of association through which the common good of members of the society is achieved. Yet this relation between individual and common good applies only under normal circumstances. 
The existence of the society and hence its having an identity and a good as an independent entity is presupposed by the ethical enquiry of its members. It is not created by the result of that enquiry. Under abnormal circumstances, the two can come apart. The good of individual members as ethically defined and their good as members of an independent entity whose primary concern must be its own continuous survival may come into conflict. Under the latter circumstances, totalizing considerations become relevant. The individual's good will be that of a vehicle for the continued existence of society and that person may sacrifice his/her life for it. In this account of the relation between totalizing and individualist ethical concerns, the good of the whole is a contextual presupposition of the enquiry into individualist ethical principles. It must also serve as a limit on how individualist principles are to be understood and applied. They can't be such as to undermine the viability of the society as a separate entity. Yet the good of the whole does not determine the content of the individualist principles. These must be arrived at through a consideration of the fundamental interests of individuals as separate entities, which involves an entirely independent commitment to pursue the common good through principles that are justifiable to each person in terms of those interests.

\section{Notes}

1. Frederick Rosen, Mill (Oxford: Oxford University Press, 2013), 1-2.

2. Rosen, Mill, 5.

3. Rosen, Mill, 4.

4. Rosen, Mill, 5.

5. Hastings Rashdall, The Theory of Good and Evil: A Treatise on Moral Philosophy (Oxford: Oxford University Press, 1924), Vol. I, 238-40.

6. Mark Philp and Frederick Rosen (eds.), John Stuart Mill: On Liberty, Utilitarianism and Other Essays (Oxford: Oxford University Press, 2015), 128.

7. It may well be questioned whether Plato's philosopher rulers are best off ruling rather than contemplating the eternal ideas. However, if they do not rule, they will be subject to the disorderly government of the ignorant and their opportunities for philosophical contemplation may be disrupted.

8. 'Kantian' is in quotation marks because what has absolute worth in Kant's ethics is the individual only insofar as his/her will is a rational one. Following that line of thought pushes Kant in the direction of a totalizing ethics.

9. Philp and Rosen, John Stuart Mill, 121.

10. Philp and Rosen, John Stuart Mill, 125.

11. Philp and Rosen, John Stuart Mill, 130.

12. As far as I know, Rawls was the first person to make this point. John Rawls, A Theory of Justice (Oxford: Oxford University Press, 1999), 24.

13. Philp and Rosen, John Stuart Mill, 129-30.

14. Philp and Rosen, John Stuart Mill, 146.

15. Philp and Rosen, John Stuart Mill, 146.

16. Philp and Rosen, John Stuart Mill, 172. 
17. Philp and Rosen, John Stuart Mill, 172.

18. Philp and Rosen, John Stuart Mill, 172.

19. Philp and Rosen, John Stuart Mill, 174.

20. Philp and Rosen, John Stuart Mill, 174.

21. Philp and Rosen, John Stuart Mill, 174-5.

22. Philp and Rosen, John Stuart Mill, 175.

23. Philp and Rosen, John Stuart Mill, 175.

24. Philp and Rosen, John Stuart Mill, 175.

25. Philp and Rosen, John Stuart Mill, 131.

26. Bernard Williams, Ethics and the Limits of Philosophy (London: Fontana Paperbacks, 1985), 105-10.

27. R. M. Hare, Moral Thinking (Oxford: Clarendon Press, 1981).

28. Philp and Rosen, John Stuart Mill, 149-51.

29. Philp and Rosen, John Stuart Mill, 149.

30. Philp and Rosen, John Stuart Mill, 172.

\section{Bibliography}

Hare, R. M. Moral Thinking. Oxford: Clarendon Press, 1981.

Philp, Mark and Rosen, Frederick (eds.). John Stuart Mill: On Liberty, Utilitarianism and Other Essays. Oxford: Oxford University Press, 2015.

Rashdall, Hastings. The Theory of Good and Evil: A Treatise on Moral Philosophy. Oxford: Oxford University Press, 1924.

Rawls, John. A Theory of Justice. Oxford: Oxford University Press, 1999.

Rosen, Frederick. Mill. Oxford: Oxford University Press, 2013.

Williams, Bernard. Ethics and the Limits of Philosophy. London: Fontana Paperbacks, 1985. 


\section{Mill and Democracy: Taking William Buckley Seriously}

Alan Ryan

I am obliged to confess I should sooner live in a society governed by the first two thousand names in the Boston telephone directory than in a society governed by the two thousand faculty members of Harvard University. ${ }^{1}$

(William Buckley, 1963)

\section{Introduction}

It is a real pleasure to have the chance to write an essay for Fred Rosen, although it is a pleasure not unmixed with some apprehension. What follows is an essay in the most literal sense, a trial balloon, intended to give the reader ideas to chew on rather than taken on trust and swallowed without reflection. There is a narrow line between inventiveness and a wholesale disregard for textual constraints and historical accuracy. Professor Rosen has always been firmly on the right side in this respect. It is enough to gesture to the Bentham edition to make the point. Nor has imagination been sacrificed to accuracy; his recent book on J. S. Mill, for instance, is full of original insights, especially into Mill's fraught relationship with Auguste Comte. So, I hope that he and I are as one in thinking, as Mill did, that on all great subjects there is more to be said, and in thinking, as Mill did not, that his demands on the electorate were unrealistic, but not absurd.

John Stuart Mill's discussions of democracy display several tensions; the one that fuels what follows is the contrast between his enthusiasm for the Athenians of the fifth century BCE and his dislike of those he 
called 'political men'. ${ }^{2}$ Pericles notoriously claimed that those who professed indifference to public affairs had no place in Athens; apolitical men were very bad citizens. ${ }^{3}$ What follows asks whether the constitutional arrangements of Athenian democracy might be a viable ideal for the modern world. I contrast a political conception of democracy as rule by the people taken as literally as possible with a social, moral and, in a broad sense, cultural conception of democracy as the character of a society, giving every member of a society equal access to the means of a fulfilled existence. Unsurprisingly, this second conception is likely to attend to schools, workplaces and cultural institutions rather than the ballot box. I end by saying a few fairly sharp things about the politics necessary to sustain this social and cultural conception of a democratic society, but very few. I am too doubtful of the prospects of radical political movements in the advanced industrial economies to have anything robust to say.

The central topics I tackle are the possibility of democracy without elections, what a political world without professional politicians might be like, what dangers it would face, whether it would not be too difficult to make it work, and whether it would not replace unaccountable professional politicians doing the bidding of special interests with unaccountable bureaucrats either themselves doing the bidding of special interests or acting as Platonic guardians in the manner of the civil servants of the East India Company, as described by Mill: providing government of the people and for the people, but not at any price government by the people. I do not tackle the currently much-discussed subject of collective action the sense in which a collective actor called 'the people' can be said to act - because I do not see far into it. I should add that my debts should be obvious; besides Thucydides at one end of the story and Dewey at the other, they begin with Plato, continue with Polybius and Machiavelli, take in Rousseau, Constant, Tocqueville and Mill, and end more recently and more locally with Joseph Schumpeter, Robert Dahl, Henry Richardson, David Estlund, Larry Bartels and Martin Gilens.

My unsurprising claim is that what we call 'liberal democracy' is not (political) democracy, although it is liberal, and is more importantly and more genuinely liberal (in the old-fashioned sense of the term encapsulated in the American and British Bill of Rights) than 'democratic'. The extensive range of human rights that liberal democracies accord their citizens is essential to their leading a decent and secure existence and enjoying the expansive educational, occupational and social opportunities that lead people to call them 'social' democracies in a non-Marxist sense; the European Convention on Human Rights (ECHR) provides a useful catalogue of such rights, ${ }^{4}$ and (unlike the amendments that make up the US 
Bill of Rights) they are explicitly understood, not simply as prohibitions on legislative action, but as requirements on governments committed to creating a democratic society. They rule out the arbitrary denial of the vote to anyone, protect political free speech, and prohibit the expulsion of one's own citizens; they demand of 'public authorities' that they take positive steps to secure equal opportunity, protect family life, and a good deal else. ${ }^{5}$ They do not give the demos the power exercised by the Athenian assembly, but establish a framework for a liberal society, and for a socially egalitarian one in some respects, if not a democratic polity strictly (or narrowly) speaking. Exactly what range of such legally acknowledged rights is definitive of a liberal regime, and how they should be construed by national and international courts (such as the European Court of Human Rights), is a large issue on which I do not here take sides. One topical question that divides liberal theorists and exercises governments in different countries, for instance, is whether legislation banning hate speech is, or is not, consistent with a liberal view of free speech rights. Like Germany, France makes Holocaust denial a crime, ${ }^{6}$ and French courts have extended that protection to the Armenian genocide of the First World War. ${ }^{7}$ Conversely, the European Court of Human Rights (ECtHR) has held that strict laws against abortion do not violate human rights, and fall within a state's legitimate sphere of cultural choice. ${ }^{8}$ Some democratic features of such societies (in the conventional political sense), such as periodic free elections, are essential to the preservation of their liberal character, though much is owed to the convictions of the elites who de facto manage those societies' affairs, as well as to the behaviour of the judiciary. ${ }^{9}$ The Convention promotes democracy, but was not democratically devised or enacted. British civil servants drafted much of the ECHR; the document was never put to a referendum, many of its provisions are unpopular with politicians, the public and the press (as is their interpretation by British courts and the ECtHR), and it's doubtful whether a majority of the British electorate would favour the Convention's prohibition of capital punishment even today. This is hardly surprising; nineteenth-century liberals fearful of the effects of extending the franchise to the lower classes thought 'the masses' were by nature illiberal, prone to moral panic and given to violence; this was a commonplace of late nineteenth-century sociology. Many upper-class Americans at the end of the nineteenth century thought universal (adult male) suffrage had been a mistake, though one it was now impossible to reverse, and Ortega y Gasset's Revolt of the Masses shows how such anxieties were exacerbated by the rise of European fascism in the 1920s. So, rule by the people and the civil liberties protected by the ECHR are in some tension as well as mutually supportive. 
As to the political regime under which the inhabitants of liberal democracies live, nobody will change their verbal habits because of anything I say, but liberal democracies are properly speaking: extensive popular mixed republics, with secure human rights, a tendency to oligarchical, plutocratic and populist distortions, to popular disaffection and apathy, and the corruption of the common people by bread and circuses. Both in the almost universal post-1945 parliamentary form and the all but unique American form, they are what writers in an older tradition would have seen as government by elective aristocracy. ${ }^{10}$ They are a version of the mixed regime, part democratic and part oligarchical, on which the Roman Republic prided itself, a system praised by Polybius, Cicero, Machiavelli, Rousseau and innumerable others; the label of 'an extensive republic' ${ }^{11}$ is Madison's, but contra Madison, who thought that extending the suffrage to persons other than property-holders amounted to the rise of democracy, the process instituted a different form of mixed republic: what Weber and Schumpeter described as 'rule by professional politicians'. ${ }^{12}$ This may or may not be the best of all possible political worlds; I think it may well be, not for Panglossian reasons, but because the possibility of instituting anything very different is so slim. My emphasis falls on possible. The non-Kojèvian version of the 'end of history' ${ }^{13}$ thesis defended by Francis Fukuyama in the early 1990s encapsulates that downbeat thought. The system is certainly susceptible to improvement, and in need of it everywhere, but it is vastly better than incompetent theocracies, Stalinist or fascist dictatorships, the kleptocracies that disfigure much of Africa and Central Asia, and the failed states found in many parts of the world. I am not going to ask whether the British, French, Canadian or American political systems are working well or badly; my question is what democracy in the picky sense - equalizing the political power of all citizens - would look like if we instituted it, what we would have to do to make it work, and whether we would like it. Since the most obvious feature of the changes about which I am speculating is the absence of professional politicians, I say something in passing, some of it mildly disobliging, about what professional politicians do and what expertise they possess; and I offer a view of the legislative process that is at odds with contemporary practice and the intuitive understanding of legislation possessed by most of the citizenry. The largest lacuna in what follows is the absence of a full account of the executive; I have conflicting thoughts about the topic, but no settled position. I am not at all clear how a 'citizens' jury' model of legislative democracy would best be instituted, and how committees of the legislature would interact with administrative and policymaking committees of the executive. That is a real gap 
in my argument. In the modern world, though not in 1787, we inevitably live in an executive-centred administrative state and need to think how to make it efficient and forward-looking. This thought explains my anxiety that democracy might be a cover for (a good-natured and public-spirited) mandarin tyranny. It is a real issue for someone whose affection for Jefferson and his ideas about ward republics does not extend to Jefferson's dislike of 'a very energetic government'. ${ }^{14}$

\section{Forms of democracy}

My main prop is the contrast between a political conception of democracy - that the power to make and enforce binding decisions on all members of the society should be shared equally among those affected - and a social conception, which holds that we are all members of a community with rich intellectual, cultural and spiritual resources that should be available to everyone without distinction of race, class, gender, creed or national origin. Both focus on equality, the first on equality of power, the second on equality of access to the cultural goods of modern society. There are other familiar distinctions on which I rely: direct versus representative, which overlaps with ancient versus modern conceptions (Madison and Jefferson thought representation was the modern discovery that rendered even the greatest of ancient writers only 'prefatory' to the moderns, while Rousseau detested the idea of representation as essentially feudal), ${ }^{15}$ amateur legislators versus professional politicians, mass conceptions versus elite conceptions, and an emphasis on class (or sectional) conflict over the distribution of economic advantage as the essence of politics. The last is my starting point; it answers the question of what democratic politics is about. In taking it for granted that non-violent class warfare is and ought to be the essence of modern politics, I am at odds with Dewey, who should have thought this, but was undermined by his own communitarianism and by a contrast, too readily taken for granted, between Europe and the United States. This was not conservatism; Dewey died at the age of 92, and voted for a winning presidential candidate only twice - in 1916 when he voted for Wilson and in 1948 when he voted for Truman; he otherwise voted for Debs, La Follette and Norman Thomas, and he said that Roosevelt's New Deal was just a bit of 'messing around'. ${ }^{16}$ When I say that non-violent class warfare is what modern politics usually is and always should be about, I mean that sectarian and highly ideological politics are not susceptible to easy compromise and sometimes not to any, ${ }^{17}$ but that non-violent class warfare is. 
It amounts to using the political system to redress the inequalities and unfairnesses of the world into which children are born willy-nilly, to insure the citizenry at large against the insecurities and anxieties that the economic system and everyday life will predictably generate, and to settle arguments about who pays how much of the bill for these protections. In the ordinary course of events, the well off, well connected, well informed and intelligent will always secure a greater share of the good things that society creates than dispassionate justice would award them a priori, and they will endeavour to ensure that their friends and families hang on to what they hold. Reinhold Niebuhr claimed that all ruling classes overpaid themselves by at least a third; ${ }^{18}$ I have no idea what the basis of the calculation might have been, but the general idea is plainly right, even if the calculation understates the extent to which the elite overcharges the rest of us. James Scott holds a similar but more jaundiced view: liberal democracies are run for the benefit of the best-off 20 per cent, and the political 'trick' that the 20 per cent and their helpers have to pull off is to persuade the next 35 per cent that they have more to fear from those below them than from those above. ${ }^{19}$ For readers of Seymour Lipset's Political Man, this is the seamy side of the story about the wonders of the 'diamond-shaped' ${ }^{20}$ distribution of income and wealth, and its effect on political stability, a thought that Lipset happily (and rightly) admits to having borrowed from Aristotle; Aristotle was not in the business of advocating democracy, but Seymour Martin Lipset was.

Class warfare, as it is understood here, is the process whereby the less advantaged use the political system to offset the economic advantages of the better off and exact a fair price for their acquiescence in the status $q u o$, or, as appears to be more common at present, the process whereby the better off use the political system to reinforce their advantages. Being well off and well connected is not the only form of advantage; being well organized on any basis - ethnic, religious, occupational, with regard to an irrational enthusiasm for guns - is the crucial asset. Being well off and well connected covers the costs of organization without anyone noticing; those with fewer resources need to do much more self-conscious organizing. The fact that organization is crucial means that another facet of democratic politics is, or should be, the defence of the unorganized many, and the public interest, against the well-organized few, and sectional interests. This is all very familiar from Mancur Olson's work ${ }^{21}$ of many years ago, and is an aspect of Rousseau's discussion of the various fractional general wills to be found in any society. ${ }^{22}$ If politics is an unseemly struggle about interests rather than a high-toned debate about principles, non-violent class warfare over the size of a group's share of the social cake is 
the route to stable compromises on distributive issues. Done properly, distributive politics is safe and lends itself to rational outcomes, while ideological politics is dangerous and unpredictable. Ideological politics may occasionally be inescapable, and the line between the two kinds of politics can obviously be blurred in all sorts of ways; indeed, if you are a member of the Weber admiration society, you will be quick to observe that some underlying ideological commitments must be in place if the constitutional rules that permit distributive politics to flourish are to be accepted; and you may go on to point out that in a Führerdemokratie, one thing the leader must do is articulate those commitments in a compelling fashion. None of this do I deny.

\section{Three questions}

So, the question is whether we do, can or want to practise democracy strictly speaking: which is to say to operate a political system in which everyone has an equal share of the power to decide on the rules that govern all the members of the political society in which they live, and an equal share in supervising their implementation. I ignore one way of achieving this, suggested years ago by Robert Paul Wolff and others. The Wolff version turns legislation into an instant plebiscite; the citizenry has a set-top box on their television sets, with three buttons for yes, no, abstain, and when legislation is to be voted on, they vote for one of the three options. ${ }^{23}$ Rousseau's version required a yearly vote, but not on particular issues: does the general will endorse the existing constitution and approve the continuance in office of the present government? In the United States, the general will would probably return a 98 per cent yes to the first question and 60 per cent no to the second, and more than that if we think of Congress as a body of 'elective aristocrats' of the sort Rousseau imagined as the best practicable government. The problems of plebiscitary democracy are well known, and the attractions of plebiscites to Napoleon III, Mussolini and Hitler, as well as the manipulation of referenda in states such as California, suggest the difficulties of achieving political equality by that route; more bleakly, Cold War liberals like Isaiah Berlin and Jacob Talmon thought that the equality of political power achieved in a plebiscitary democracy would be such that everyone except the dictator in charge has none. ${ }^{24} \mathrm{He}$ will ask the questions, make it clear what the answer is, and we will press the right button for fear of the secret police. Saddam Hussein could get 99 per cent support from 99 per cent of the population, as could Joseph Stalin. 
Anyone who asks my three questions (whether we do, can or want to practise democracy) can be expected to say no to at least one of them. I answer them as follows: we don't, we could, but it might not be worth the effort. If we confine the question to political systems, my answer is that so-called liberal democracies do not practise democracy, are not designed to practise democracy, and that the United States was set up as something other than a democracy when more democratic options were available. The British system was never conceived as a democracy, actual or incipient; it aimed at 'representative and responsible government', and the nineteenth- and twentieth-century expansion of suffrage was a matter, in Gladstone's phrase, of bringing the previously excluded 'within the pale of the constitution'; 25 this meant allowing lower-class men to get the vote as and when it seemed safe to allow them to have it. The long exclusion and eventual inclusion of women is another story, not to be tackled here. The extension of suffrage ${ }^{26}$ to working men after 1867 was not particularly grudging; advocates of a wider suffrage believed that unless the working class sent members to parliament, even the best-intentioned administration would lack the knowledge needed to implement its benign intentions. The constitution was not democratic, but liberal; its essence was the rule of law, not political equality. Liberal democracies permit the representation of interests and allow for the rejection of our rulers through the ballot, but they do not aim at the equalization of the power to decide outcomes and the rules determining outcomes. If we go on to ask whether we could practise democracy, the answer is that we could. The usual view that what Jefferson called 'true democracy' in distinction to 'representative democracy' ${ }^{27}$ is impossible in countries as large as the United States is false. We could institute genuine democracy, but it would be hard work and require changes in our intellectual and political habits. It might also be a terrible disappointment, because we might find that in order to achieve a coherent system, we had handed ourselves over to an oligarchy of experts, or had been bamboozled by competing demagogues. Small-scale experiments with the institutions that real democracy might involve would not be impossible, and have been tried; my anxiety is that scaling them up to a national level might not be worth the effort. When I say 'not worth the effort', I mean that unless we attach overwhelming value to the achievement of political equality itself, much of what we might hope political equality to yield could be had within the existing framework, and the almost vanishingly small (but equal) chance to determine national policy and supervise its implementation (which is the real pinch of the argument from size) hardly seems worth hankering after. This is not an endorsement of Benjamin Constant's criticism of the 
liberty of the ancients, ${ }^{28}$ which focused on the way most ancient republics crushed individuality; what it says is that the amount of 'ancient liberty' each person would get - their 'share of the sovereignty' - would be too small to be worth taking seriously. I think that is right, although it does not bite on proposals that could be implemented at a local level, nor on proposals to submit national policy to appropriately constructed randomly selected panels afforced by expert advisers, rather than elected politicians, which would have other merits besides equalizing the power to decide.

We should therefore think about William Buckley and the Boston phone book. Looked at in a different light, the replacement of an elected Congress or House of Commons with a legislature chosen by an appropriately constructed lottery would have benefits of a different kind from the bare equalization of power. Before embarking on an explanation of that, I repeat that the political system we do have is a respectable form of government in its uncorrupted form, and its longevity would have been admired by many writers on how to build a successful republic, beginning with Aristotle - though not Plato - and continuing via Polybius, Cicero, Marsilio of Padua, Machiavelli, Harrington, Sidney and Montesquieu, and even Rousseau. Madison might have been surprised to find how long his creation had lasted, but depressed to discover how much better a parliamentary republic works than the republic he actually created, hamstrung as it is by the separation of executive from legislature. The British affection for parliamentary sovereignty goes too far, but the sovereignty of parliament has its virtues, in enabling decisive government and potentially, though not so much in practice, in aiding accountability.

Finally, I turn very briefly to the third interpretation of the question, in effect asking the obvious question: 'If there is an understanding of democracy that does not focus narrowly on political arrangements, what is it, do we want social or cultural or whatever we should call it democracy, and how does it connect with our political arrangements narrowly considered?' The answer is, of course there is, it is what Tocqueville admired and Dewey praised as America's contribution to the modern world, we do - or should - want it, and knowing what sort of politics best sustain it is not easy, let alone what the prospects are for that politics. But if 'real' democracy is too demanding, enthusiasts for democracy should think about the distance between it and what we do have because the extent of political inequality raises urgent questions about how we can hold the wielders of power accountable within the existing framework.

Democracy, politically speaking, means what it says: the rule of the demos, the common people, the people that Aristotle called 'the 
poor many'. Anything that gets in the way of the common people exercising power is a dilution of the democratic principle, whether that dilution is a good or a bad thing. This view is the polar opposite of Dworkin's in Freedom's Law, and of his view of the connections between liberalism and democracy in his long-ago essay on 'Liberalism' in Public and Private Morality. ${ }^{29} \mathrm{I}$ do not deny that there are liberal arguments for democracy - along the lines of arguing that since we are born free and equal, we can only be governed by our own consents, which is the line taken in Freedom's Law. ${ }^{30}$ My take is different; it is interest-based, not rights-based and not focused on when one person or group of persons has the right to coerce others into acting in one way rather than another; it thinks in terms of redressing imbalances between the lower and upper classes and between well-organized sectional interests and the indefinite 'public' at large. We are used to distinguishing between democracy and majority tyranny and saying that the latter 'can't really be' democracy, because we don't approve of it but we do approve of democracy. Hobbes took the line I follow here; he claimed that tyranny is but monarchy misliked; ${ }^{31}$ I side with the tradition which held that a tyrannical democracy is not a contradiction in terms. Extra-legal violence and expropriation are tyranny, while the exercise of legal authority according to the local rules is, by and large, not - although we might think the local rules are themselves tyrannical. Socrates's execution for blasphemy was not a case of majority tyranny, though the Athenian law was illiberal, superstitious and a disgrace to the city. The Athenians were, as Pericles told them, multiperson tyrants vis-à-vis their tributary states, but not vis-à-vis themselves. ${ }^{32}$ The unconstrained version of democracy says simply that the ordinary people rule. They may pass whatever laws seem good to them, make whatever executive decisions seem good to them, and enforce the laws as they see fit, so long as they do it in proper form; this is the sovereignty of the people rather than the sovereignty of parliament. ${ }^{33}$ If they have any sense, they will impose restraints on themselves to avoid civil war, to avoid self-destructively impulsive policymaking, and protect civil rights. Northern Ireland should be kept in mind, as well as the aftermath of the Arab Spring. Athenian democracy was not in the modern sense liberal; it could be relaxed and unpunitive, but it was not so on principle, and not because it thought individuals had a right to go their own way in any particular area. And in the sphere on which modern liberalism is grounded, religious liberty, their principled view was that anyone who undermined the civic cult endangered the polis. ${ }^{34}$ 


\section{Classical and modern democracy}

We should pause for some demography, since size is the usual argument against invoking the classical idea of democracy as a standard for modern politics, and one I have conceded if the argument is about 'a share of the sovereignty'. Athens, where democracy was practised and gained an alarming reputation in the eyes of respectable opinion, was the largest Greek city-state. It had at its most prosperous around 300,000 inhabitants; some 200,000 were native-born, and free, the others were slaves and foreigners. Perhaps a quarter lived in the city. Women, children, slaves, foreigners and the poorest free males were ineligible to take part in politics. The consensus is that, at a maximum, Athens may have enrolled 30,000 to 40,000 citizens as eligible to speak and vote in the assembly. Even so, the assembly might be attended by up to 8,000 adult citizen men, entitled to vote in person on just about anything. What we talk about was invented a very long time ago - conventionally in 508 BCE - for a small city (by our standards). Just which elements of what they invented make sense in a country of 300 million is a question with no simple answer, but we have committed ourselves to believing in something for which they provided the label.

Why did they create, defend and die for this political system? There are two reasons. Democracy expressed the thought that every citizen was the equal of every other citizen so far as the entitlement to exercise power was concerned. This wasn't economic equality - Athenian leaders were notably upper class - and nobody thought that all Athenians were equally intelligent, let alone equally brave or far-sighted. They were exceedingly competitive, not given to modesty, and alarmingly willing to do down anyone else for the sake of their own advantage. Socrates's interlocutors, Thrasymachus, Callicles and Polus, make that clear enough. ${ }^{35}$ But they wanted to secure political equality, and to a striking extent they did. In part, this was achieved by opening the assembly to most of the free adult male population, in part by rotating office at very frequent intervals, and in part by confining the use of election to a small number of positions, using lotteries for the rest. We still do the latter for picking juries, which formed a substantial part of Athenian public life. The second reason, which animates a good deal of these procedures, was self-defence: many thought with good reason that the well born and well connected were likely to reduce the poor to servitude; and in the alternative that if the well born and well connected squabbled among themselves, there'd be civil war and then tyranny. The effect of spreading the holding of office 
very widely was that almost anyone who wanted to might find himself chairing the assembly once or twice in his lifetime, or serving on an important legal case. And decisions had consequences: if you were one of the thetes and voted for war in the assembly, you'd find yourself going home to get the cushion you sat on when rowing a trireme. This didn't have the chastening effect that one might hope.

Now consider ourselves. We certainly have some beliefs in common with the Athenians. One is the belief in accountability; another is the wish not to be tyrannized over by the well born and well connected. It is hard to know whether they or we take economic exploitation the more seriously. A lower class with the instincts of ancient Athenians would perhaps be sceptical about the way in which members of Congress make so much money in spite of professing to be ordinary folk just like their electors. Athenians seemed to accept the prominent role of the better born without complaint, but it's hard to believe they would not have noticed that in the past 30 years the median wage has stagnated while the bestoff 1 per cent have seen their incomes triple. But we are not committed to isegoria. ${ }^{36}$ As Max Weber said, what we call democracy is rule by professional politicians, not an aristocracy of birth, but certainly a self-reproducing oligarchy, and in practice a plutocracy. ${ }^{37} \mathrm{It}$ is not a central aim of the system we operate that each person has an equal share of political power; the existence of professional politicians is inconsistent with it. In the United States, though less so in Britain and in much of Europe - with the exception of Switzerland and, even more so, (tiny) Liechtenstein there is a closer approximation to political equality locally; but the contrast between being cajoled into serving on a school board or the local sewer committee and deciding whether to risk everything on war with Sparta remains important. A lot of people serve on some sort of public body in a lifetime, but the proportion of the adult male population that does so is nonetheless very small - while the proportion of the female population that does so is also small, but infinitely higher than in Athens.

So, we have a popular republic with what Polybius and others called a 'mixed constitution'. ${ }^{38}$ Crafted for a large country, not a small city-state, it is an extensive republic. A mixed republic is in intention neither a democracy, nor an aristocracy, nor a monarchy, but contains elements of all three in the hope that we can get the decisiveness of one-man rule, the wisdom of an aristocracy, and the common sense and immunity to corruption of the ordinary person. The historical example on which all writers drew was the Roman Republic - not the empire ruled by whatever autocrat the Praetorian Guard installed, but the republic that had evicted the Tarquins, overcome the conflicts between patricians and plebeians, 
and achieved a balance that lasted until rich men raised private armies. This is not the place to explore the substantial gap between the oligarchical realities of Roman political life and the rhetorical gloss placed on them by later writers. But one way in which reminding ourselves that we live in a modified Roman republic may have some therapeutic value is to recall the ways in which that sort of regime runs into trouble. The Roman system was intended to promote consensus by making it difficult for any of the holders of power to act independently of the others. The obvious danger of such a system is that it will simply grind to a halt if everyone digs their heels in. Another is that it depended on a clientelist ethos. We, of course, are opposed to clientelism - but practise it in our own way. It may not be the degeneration of a democracy that we should fear, but the degeneration of a mixed republic.

Madison's republic was designedly more anti-democratic than what we have today, and indeed than it became by around 1830. But it was always a popular republic to a degree that Rome never was; Rome confined the holding of public office to members of the equestrian and senatorial classes, and had an elaborate cursus honorum that ensured 'new men' took a long time to reach high office. It reinforced the oligarchical character of the republic by organizing the voting process that confirmed legislation and elected officials in such a way that each 'century' voted as a bloc, which meant that the upper classes whose centuries contained fewer members than those of the less well off had far more voting power than the lower classes; and votes were taken with the upper classes voting first and the process stopping as soon as a majority was reached - thus avoiding the question of how firm a majority had been secured. From the outset, the American version placed few restrictions - other than sex, race and initially property - in the way of holding public office; Madison lost his fear of the majority tyranny the poor would practise if they had easy access to the ballot box or too firm a grip on Congress, but it is worth remembering that devices such as the electoral college and the indirect election of senators were intended to achieve 'Roman' results - the election of upper-class candidates - in the absence of a cursus honorum. Tocqueville's comments on the contrast between the members of the Senate and the members of the House suggest it was working in 1832. ${ }^{39}$ Changes since the Founders set up the system have moved it in what everyone would describe as a democratic direction, but which I will continue to call a 'popular' direction. In other respects, the Romans and we run a more 'open' system than the Athenians. The Athenians insisted that citizens were the offspring of two citizen parents, but we have abandoned ethnicity, gender and race as barriers to public office and, unless we want 
to run for president, the obstacle of one's birthplace can be overcome by a few years of residence and the cooperation of the INS (the Immigration and Naturalization Service). The Romans were like us in being ethnically open as the Athenians were not.

Nonetheless, what we have is not democracy because it does not equalize political power - in the sense that it does not equalize the chance of holding public office or making and supervising the implementation of important decisions. A self-selected class of persons holds most offices and most seats in Congress. Could anything be done to alter this? The answer is yes, but when people see the answer they flinch. The legislative branch should be selected by lottery; the administrative machinery should be selected by competitive tests of an appropriate kind, and promotion within the administrative mechanism should be by merit; I am inclined to think that the head of the executive should be elected by the legislative body and be subject to dismissal by it, but by a super-majority. It is not clear to me what sort of cabinet s/he would need, but plainly a system of heads appointed by the chief executive and themselves supported by a cabinet would be an obvious choice. William Buckley said he'd rather be governed by the first 2,000 people from the Boston phone book than the faculty of Harvard; he should have gone further. He should have said we'd do better with a pool of legislators drawn from the entire population than with the House and Senate as currently constituted. I take the United States for ease of illustration, but the argument holds in any modern state, certainly the United Kingdom. The United States has, as the old saying had it, the finest legislature that money can buy, and even in countries that are much more restrictive of political expenditures than the United States, access to substantial financial resources is necessary for election, and after election the opportunities for making large amounts of money are numerous. One virtue of choosing your legislators by lottery is that they can't be bought - ahead of time; with rapid turnover and ferocious policing, you can prevent them being bought at all. But we aren't thinking about how good, bad or indifferent a randomly selected legislature of 535 persons would be, but whether this equalizes power.

It doesn't do what is manifestly impossible, namely stick all 180 million adult Americans in an assembly on the Pnyx and let them vote on everything and anything. In that sense, it offers the citizen less than the set-top box proposal. It gives everyone an equal, but very, very small, chance of serving - which is why republics such as Renaissance Florence used lotteries ${ }^{40}$ for such purposes. Most people's reactions to the idea are sceptical, sometimes because they think a random selection of the 
population would throw up a collection of oddballs; others because they fear ordinary folk wouldn't know all sorts of things that they suppose politicians do know. The first can be dealt with by some pretty minimal constraints on how you draw your sample. The second exaggerates the competence of politicians. Most politicians know very little about almost everything they vote on. I have taught enough of them to know that this is not because they are stupid or ill-educated. The reason is that nobody is an expert on more than a couple of areas, and almost all of us are wholly dependent on others in almost all areas of human knowledge; this is one way in which Schumpeter's broad-brush division between the ignorant mass and the informed elite is misleading. What professional politicians $d o$ is act as intermediaries between citizens and government: they act as social workers to the poor when they need help dealing with social services, and as lobbyists for the better off when businesses and professions (and retired persons) need political favours. ${ }^{41}$ They seem to perform it very efficiently. Martin Gilens has done some interesting research which shows that on several hundred issues where the preferences of the public can be ascertained, the outcomes followed the preferences of the most affluent; only when the preferences of poor and middle-income Americans coincided with the preferences of the most affluent did the outcome follow their preferences. ${ }^{42}$ Larry Bartels's work showed the same thing. ${ }^{43}$ The explanation is too obvious to belabour it.

I take for granted that the random sample would have to be properly taken; all opinion polling rests on the assumption that we know how to take a properly representative sample. The question is what it is to $d o$. A random sample of the population could be a perfectly effective legislature if we rethink the way legislation works. Remember that the field where we allow the ordinary person selected at random to make vital decisions is when we call them for jury service. A defendant in a criminal trial depends on the good sense of a dozen persons chosen at random to keep him/her out of jail or save his/her life, and in a civil case to save him/her from bankruptcy, or whatever. The jury's effectiveness depends on the probity and hard work of the prosecuting and defending counsel; that is where expertise and knowledge are important (and where the less well off lose out). But the jury's task is to decide, either on the balance of probabilities or beyond reasonable doubt, which story they have been told is true or closer to the truth. The analogy, if you made the bold leap to choose your legislators by lot, is not hard to perceive. The legislature would need to be presented with legislative proposals and a story about their likely effects, and then make up its collective mind on whether it should or should not believe what it heard. It seems overwhelmingly 
likely that they would behave as all such bodies always have and break up into committees for detailed discussion, reporting back to 'the committee of the whole' for a final vote; and they would need a good deal of clerical and administrative support to do it effectively. The Athenians understood this; draftsmen wrote their legislation (though they also seem to have drafted in the assembly itself) and they ensured that speakers pro and contra were heard. Just as juries need not be experts, but are utterly dependent on them, so it is with legislatures. The place where expertise is needed is in making policy and drafting legislation. One reason why legislation so often disappoints those who initially wanted it is that by the time politicians, lobbyists and staffers have finished with the drafting process, the result is as unfit for inspection as Bismarck said the process of its creation was. The role of legislators under any system ought to be to decide what they want from a law and then to approve or disapprove what they are offered, as Mill argued. Under a system where the legislature was selected by lot, that would be especially obvious.

There is a lot more to be said about the institutional arrangements that would be needed to formulate public policy and implement it, but there is a long history of well-organized republics in which these devices worked for a substantial period of time. There are many possibilities. The most important thing about any institutional design along these lines is that a modern version would be very dependent on a really good civil service with a strong esprit de corps - which might make one fear that having got rid of one professional political class we would have created another, and that instead of having our politicians bought and sold out in the open, we'd have our bureaucrats corrupted on the quiet. One really valuable outcome, however, is that in abandoning representative government of one kind - the one that depends on electing representatives from geographical districts - we would have created another kind of representativeness - one where the legislature would be a representative cross-section of the population. That would be worth having. Introducing elements of it even within the present political and economic system would be well worth doing.

I should point to two obvious problems with choosing our congress by lot. The first is that those selected might not wish to serve. Those of us who are addicted to politics would surely enjoy having even one five-hundredth of the power to determine legislation for the entire country. Most sensible people would regard spending three years as randomly selected members of the legislature as an interference with everyday life. They already dislike the fairly minimal interruption to their lives imposed by 
jury service; how would they react to the much greater interruption that this would involve? Even in Athens, attendance at the assembly was heavily slanted towards the better off. The answer must be to pay them very well. The second obvious problem is corruption. There would be no vast expenditure on elections if there were no elections, but it defies belief to think that special interests would not seek ways to bribe the legislators. If we elected the executive - or if the legislature did it in the classical fashion - we'd run the risk of corruption at that point. One remedy in the old literature was rapid rotation in office, but aside from the problem of an inexperienced executive making every possible mistake and demitting office just as $\mathrm{s}$ /he had begun to get the hang of things, one can always bribe people with the promise of a job or a share in some lucrative deal in future; it needn't be, and usually isn't, anything so vulgar as cash in a brown paper bag.

\section{Conclusion}

So, we could institute real democracy - that is, the equalization of power over the whole nation - but it might be very hard work, it might end up leaving power in a different set of unaccountable hands, and it presupposes a population more interested in politics and policymaking than the population seems to be. Yet, less than 50 years after Madison set out to avoid creating a democracy, Tocqueville's best-seller was called Democracy in America. It is true that $\mathrm{J}$. S. Mill said that the book was really a study of equality not democracy, ${ }^{44}$ but that was a lone quibble; even though I'm on Mill's side on the issue, that's only two lone voices. Given that I don't expect to remodel the political vocabulary of the rest of the world, it may be more fruitful, if less interesting, to ask, 'What is democracy in this sense?' What politics might sustain it?

Tocqueville called it 'equality of condition'. Partly it is political: there are no qualifications of wealth, birth, lineage, to run for office. The rest is social. It is all immensely familiar. Whether Americans are still as self-reliant as they think is a matter for debate; the sturdy yeoman farmer is less visible than the agricultural corporation growing subsidies. Still, in terms of the American self-image, self-reliance is central. The converse is that neither the paternalist social welfare state nor the premodern state, with its urge for policing the morals of the citizenry, holds many attractions. There is a commitment to social mobility, however, honoured in the breach; ambition is thought to be a virtue in anyone, no matter how humble their origins. My station and its duties is not an American ideal, 
which is why there are next to no genuine conservatives in America, no matter what they call themselves. Mrs Alexander's 'All Things Bright and Beautiful' sticks in American throats when it comes to the lines: 'The rich man in his castle/ The poor man at his gate,/ God made them high and lowly,/ And ordered their estate. ${ }^{45}$ This is another way of reminding us of the old cliché that the United States is a non-feudal country, or rather that it had no feudal past, and has no feudal remnants to get in the way of the ideal of 'the career open to talent'.

The question to which Mill did not pay enough attention is this: what kind of politics is essential to the preservation of democracy in its social sense? I think that almost any version of my Athenian model would be more likely to achieve it than what we have. ${ }^{46}$ In the absence of a 'back to Pericles' groundswell, the alternative is that those whose interests would otherwise be overlooked have to use the political machinery we do have - well described by Schumpeter and other theorists of elite competition - to put the fear of God into the professional politicians who form the 'elite'. It may, of course, be a lost cause; all the survey evidence suggests that it is. In which case, we shall have to make the best of plutocracy, and a regime built on panem et circenses - bread and circuses for the Romans, but fast food, celebrity culture, sports TV and mass distraction for us. There have been, and in many places there are, very much worse regimes than that. But we shouldn't delude ourselves that it amounts to democracy, either political or social.

\section{Notes}

1. William Frank Buckley, Rumbles Left and Right: A Book about Troublesome People and Ideas (New York: Putnam, 1963), 134.

2. John Stuart Mill, The Collected Works of John Stuart Mill, Vol. V-Essays on Economics and Society Part II, ed. John M. Robson, intro. Lord Robbins (Toronto: University of Toronto Press; London: Routledge and Kegan Paul, 1967), 720.

3. Thucydides, The Peloponnesian War (London: J. M. Dent; New York: E. P. Dutton, 1910), 2.41.5.

4. Rights Info, The European Convention on Human Rights. https://rightsinfo.org/the-rights-in-theeuropean-convention/ (accessed 14 June 2018).

5. The concept of 'public authority' is pretty wide; institutions that systematically affect someone's life chances fall under the rubric, so that even private schools and colleges are covered by the ECHR as implemented in the UK Human Rights Act 1998.

6. Michael J. Bazyler, 'Holocaust Denial Laws and Other Legislation Criminalizing Promotion of Nazism', Yad Vashem - The World Holocaust Remembrance Center. https://www.yadvashem. org/holocaust/holocaust-antisemitism/holocaust-denial-laws.html (accessed 14 June 2018).

7. Jonathan Head, 'French Senate Passes Armenian Genocide Law', BBC News, 23 January 2012. https://www.bbc.co.uk/news/world-europe-16677986 (accessed 14 June 2018).

8. Grégor Puppinck, 'Abortion and the European Convention on Human Rights', European Centre for Law and Justice, 2014. https://eclj.org/abortion/echr/abortion-and-the-european-convention-on-human-rights (accessed 14 June 2018).

9. It is a count against Schumpeter's so-called 'realist' definition of democracy that because he does not build in a requirement that every competent adult member of the society should have 
the vote, it seems that apartheid South Africa was a democracy whose government was scrupulously committed to securing a legal basis for its racist and oppressive policies. The nationalist governments of the day prided themselves on running a parliamentary democracy quite unlike the assorted military dictatorships and kleptocracies farther north. See J. Schumpeter, Capitalism, Socialism and Democracy (London: 1943), Chs 21-3.

10. In spite of his reputation as an advocate of participatory democracy, Rousseau in fact thought elective aristocracy the best of all forms of government and hereditary aristocracy the worst; he skated over the tendency of the former to turn into the latter, but the Genevan authorities took the point and burned Social Contract.

11. James Madison, 'Observations by J. M.'. http://oll.libertyfund.org/titles/1934\#Madison_1356-02_799 (accessed 14 June 2018).

12. Wolfgang J. Mommsen, Max Weber and German Politics, 1890-1920 (Chicago: University of Chicago Press, 1990), 407.

13. Francis Fukuyama, The End of History and the Last Man (Harmondsworth: Penguin, 1992).

14. Thomas Jefferson, The Works of Thomas Jefferson, Federal Edition (New York and London: G. P. Putnam's Sons, 1904-5), Vol. 5. http://oll.libertyfund.org/titles/802\#Jefferson_0054-05_442 (accessed 27 February 2019).

15. Jean-Jacques Rousseau, The Social Contract. In The Social Contract and Other Later Political Writings, ed. V. Gourevitch (Cambridge: Cambridge University Press, 1997), Bk III, Ch. 15, 113-16.

16. James Campbell, The Community Reconstructs: The Meaning of Pragmatic Social Thought (Urbana: University of Illinois Press, 1992), 38.

17. Of course, the two different kinds of politics lock into each other; Northern Ireland was a confessional state in which a compact Protestant majority employed the first-past-the-post electoral system to freeze the Catholic minority out of employment, public housing and decent schools, while still requiring them to pay the same taxes as everyone else. It is not very surprising that the 'troubles' that lasted 30 years came to an end when Catholic Eire became more prosperous than Ulster; nor is it surprising that the Reverend Ian Paisley couched his demands for the end of direct rule from Westminster in terms of restoring 'democracy', by which he meant the restoration of the ability of the Protestant majority to return to its old exploitative ways.

18. Reinhold Niebuhr, Moral Man and Immoral Society: A Study in Ethics and Politics (New York: Scribner, 1937).

19. James C. Scott, Two Cheers for Anarchism: Six Easy Pieces on Autonomy, Dignity, and Meaningful Work and Play (Princeton: Princeton University Press, 2012), 18.

20. Seymour M. Lipset, Political Man: The Social Bases of Politics (London: William Heinemann, 1963), 50.

21. Mancur Olson, 'Dictatorship, Democracy, and Development', American Political Science Review 87/3 (September 1993): 567-76.

22. Rousseau, The Social Contract, II, 3, 4, 60 .

23. Robert P. Wolff, In Defense of Anarchism (Berkeley: University of California Press, 1970).

24. Jacob Talmon, The Origins of Totalitarian Democracy (London: Secker \& Warburg, 1952) and Isaiah Berlin, 'Two Concepts of Liberty' (1958), in Four Essays on Liberty (Oxford: Oxford University Press, 1969).

25. 'I venture to say that every man who is not presumably incapacitated by some consideration of personal unfitness or of political danger is morally entitled to come within the pale of the Constitution.' Speech in the House of Commons (11 May 1864). https://api.parliament.uk/historic-hansard/ commons/1864/may/11/second-reading\#column_324 (accessed 28 February 2019).

26. I emphasize 'to men'. Its extension to women was absurdly slow and grudging.

27. Merrill D. Peterson, The Jefferson Image in the American Mind (Charlottesville: Thomas Jefferson Memorial Foundation, 1998), 108.

28. Benjamin Constant, 'The Liberty of the Ancients Compared with that of the Moderns' (1819), in Constant: Political Writings, ed. Biancamaria Fontana (Cambridge: Cambridge University Press, 1988).

29. Ronald Dworkin, 'Liberalism', in Public and Private Morality, ed. Stuart Hampshire (Cambridge: Cambridge University Press, 1991), 113.

30. Ronald Dworkin, Freedom's Law: The Moral Reading of the American Constitution (Oxford: Oxford University Press, 1996).

31. Thomas Hobbes, Leviathan, Ch. XIX: 'There be other names of Government, in the Histories, and books of Policy; as Tyranny, and Oligarchy: But they are not the names of other Formes of Government, but of the same Formes misliked.'

32. Thucydides, The Peloponnesian War, 1.18. 
33. This is about the only point on which I find myself in agreement with former Supreme Court Justice Antonin Scalia - and, of course, if there was an entrenched version of the ECHR, my agreement would be hedged in ways he would not have cared for.

34. Pericles emphasizes that they don't mind mere difference; they are not oppressive like the Spartans; but they are not us.

35. Thrasymachus in Plato's Republic; Callicles and Polus in his Gorgias.

36. Isegoria: 'an equal right to be heard in the sovereign assembly of the state before public decisions were taken'. John Dunn, Western Political Theory in the Face of the Future (Cambridge: Cambridge University Press, 1979), 17.

37. Wolfgang J. Mommsen and Jurgen Osterhammel, Max Weber and His Contemporaries (Oxon: Routledge, 2006), 133.

38. Polybius, The Histories, Vol. V, Bks. 16-27, trans. W. R. Paton, rev. F. W. Walbank and Christian Habicht (Cambridge: Harvard University Press, 2012).

39. Alexis de Tocqueville, Democracy in America, eds. Henry Reeve and John C. Spencer (New York: G. Adlard, 1839), 198.

40. Oliver Dowlen, Political Potential of Sortition (Exeter: Imprint Academic, 2015), Chs 3 and 4.

41. The work that politicians do in assisting constituents with their dealings with the assorted bureaucracies is not to be deprecated; the INS would never have confessed to my daughter that they had lost her application for citizenship if Gary Hart, whom I happened to be supervising for a doctorate, hadn't twisted my arm into having him talk to Senator Lautenberg, who persuaded the INS in Newark, NJ, to 'fess up and restart the process'. Still, it is second best to public servants who do their job properly.

42. Martin Gilens, Affluence and Influence: Economic Inequality and Political Power in America (Princeton: Princeton University Press, 2012), 3.

43. Larry M. Bartels, Unequal Democracy (Princeton: Princeton University Press, 2016), 235.

44. John Stuart Mill, Dissertations and Discussions: Political, Philosophical, and Historical (London: John W. Parker and Son, 1859), 7.

45. Eric M. Sigsworth, In Search of Victorian Values: Aspects of Nineteenth-Century Thought and Society (Manchester: Manchester University Press, 1988), 147.

46. Decency demands that I remind you that Bartels and Gilens observe that the less well off would generally favour 'liberal' economic policies and 'conservative' social policies; same-sex marriage might do less well than a national health service even after the mandarin administrative elite had done their best ...

\title{
Acknowledgements
}

\author{
With thanks to Nastia van der Meer in the History Department at the Uni- \\ versity of Warwick for her assistance with the notes and bibliography, \\ and to Mark Philp for his help in making this essay fit for publication.
}

\section{Bibliography}

Bartels, Larry M. Unequal Democracy. Princeton: Princeton University Press, 2016.

Bazyler, Michael J. 'Holocaust Denial Laws and Other Legislation Criminalizing Promotion of Nazism', Yad Vashem - The World Holocaust Remembrance Center. https://www.yadvashem. org/holocaust/holocaust-antisemitism/holocaust-denial-laws.html (accessed 14 June 2018).

Berlin, Isaiah. 'Two Concepts of Liberty' (1958). In Four Essays on Liberty. Oxford: Oxford University Press, 1969.

Buckley, William Frank. Rumbles Left and Right: A Book about Troublesome People and Ideas. New York: Putnam, 1963.

Campbell, James. The Community Reconstructs: The Meaning of Pragmatic Social Thought. Urbana: University of Illinois Press, 1992. 
Constant, Benjamin. 'The Liberty of the Ancients Compared with that of the Moderns (1819)'. In Constant: Political Writings, edited by Biancamaria Fontana. Cambridge: Cambridge University Press, 1988.

Dowlen, Oliver. Political Potential of Sortition. Exeter: Imprint Academic, 2015.

Dunn, John. Western Political Theory in the Face of the Future. Cambridge: Cambridge University Press, 1979.

Dworkin, Ronald. Freedom's Law: The Moral Reading of the American Constitution. Oxford: Oxford University Press, 1996.

Dworkin, Ronald. 'Liberalism'. In Public and Private Morality, edited by Stuart Hampshire. Cambridge: Cambridge University Press, 1991.

Fukuyama, Francis. The End of History and the Last Man. Harmondsworth: Penguin, 1992.

Gilens, Martin. Affluence and Influence: Economic Inequality and Political Power in America. Princeton: Princeton University Press, 2012.

Head, Jonathan. 'French Senate passes Armenian Genocide Law'. BBC News, 23 January 2012. https://www.bbc.co.uk/news/world-europe-16677986 (accessed 14 June 2018).

Hobbes, Thomas. Leviathan. London: Andrew Crooke, 1651.

Jefferson, Thomas. The Works of Thomas Jefferson, Federal Edition, Vol. 5. New York and London: G. P. Putnam's Sons, 1904-5. http://oll.libertyfund.org/titles/802\#Jefferson_0054-05_442 (accessed 27 February 2019).

Lipset, Seymour M. Political Man: The Social Bases of Politics. London: William Heinemann, 1963.

Madison, James. 'Observations byJ. M.'http://oll.libertyfund.org/titles/1934\#Madison_1356-02_799 (accessed 14 June 2018).

Mill, John Stuart. Dissertations and Discussions: Political, Philosophical, and Historical. London: John W. Parker and Son, 1859.

Mill, John Stuart. The Collected Works of John Stuart Mill, Volume V-Essays on Economics and Society Part II. Edited by John M. Robson, introduction by Lord Robbins. Toronto: University of Toronto Press; London: Routledge and Kegan Paul, 1967.

Mommsen, Wolfgang J. Max Weber and German Politics, 1890-1920. Chicago: University of Chicago Press, 1990.

Mommsen, Wolfgang J. and Osterhammel, Jurgen. Max Weber and His Contemporaries. Oxon: Routledge, 2006.

Niebuhr, Reinhold. Moral Man and Immoral Society: A Study in Ethics and Politics. New York: Scribner, 1937.

Olson, Mancur. 'Dictatorship, Democracy, and Development', American Political Science Review 87/3 (September 1993): 567-76.

Ortega y Gasset, José. The Revolt of the Masses. London: G. Allen and Unwin, 1932.

Peterson, Merrill D. The Jefferson Image in the American Mind. Charlottesville: Thomas Jefferson Memorial Foundation, 1998.

Polybius. The Histories, Volume V: Books 16-27. Translated by W. R. Paton, revised by F. W. Walbank and Christian Habicht. Cambridge: Harvard University Press, 2012.

Puppinck, Grégor. 'Abortion and the European Convention on Human Rights', 2014. European Centre for Law and Justice. https://eclj.org/abortion/echr/abortion-and-the-european-convention-on-human-rights (accessed 14 June 2018).

Rights Info. The European Convention on Human Rights. https://rightsinfo.org/the-rights-in-theeuropean-convention/ (accessed 14 June 2018).

Rousseau, Jean-Jacques. The Social Contract and Other Later Politicial Writings. Edited by Victor Gourevitch. Cambridge: Cambridge University Press, 1997.

Schumpeter, Joseph. Capitalism, Socialism and Democracy. London: G. Allen and Unwin, 1943.

Scott, James C. Two Cheers for Anarchism: Six Easy Pieces on Autonomy, Dignity, and Meaningful Work and Play. Princeton: Princeton University Press, 2012.

Sigsworth, Eric M. In Search of Victorian Values: Aspects of Nineteenth-Century Thought and Society. Manchester: Manchester University Press, 1988.

Talmon, Jacob. The Origins of Totalitarian Democracy. London: Secker \& Warburg, 1952.

Thucydides. The Peloponnesian War. London: J. M. Dent; New York, E. P. Dutton, 1910.

Tocqueville, Alexis de. Democracy in America. Edited by Henry Reeve and John C. Spencer. New York: G. Adlard, 1839.

Wolff, Robert P. In Defense of Anarchism. Berkeley: University of California Press, 1970. 


\section{3}

\section{John Stuart Mill and the Jewish Question: Broadening the Utilitarian Maximand}

Samuel Hollander

\section{Introduction}

Edward Alexander in his The State of the Jews: A Critical Appraisal (2012) asserts that 'John Stuart Mill was neither anti-Semite nor philo-Semite, but a tertium quid foreshadowing a political type of more immediacy to my subject than the two Arnolds themselves'. ${ }^{1}$ By the two Arnolds he meant Thomas, Headmaster of Rugby School, who explained to a correspondent in 1834 that he 'must petition against the Jew Bill'2 because it is based on 'that low Jacobinical notion of citizenship, that a man acquires a right to it by the accident of his being littered inter quatuor maria [on the nation's soil] ${ }^{3}$ or because he pays taxes'; ${ }^{4}$ and Thomas's son, Matthew, 'a (relatively) straightforward philosemite, just as his father had been an unqualified antisemite'. ${ }^{5}$ And by the contention that Mill 'foreshadowed a certain political type' Alexander intends modern-day Israel's 'ideological enemies ... [who] have long done battle with that straw man they call "Zionists who want to silence all criticism of Israel", mythical creatures nobody has ever been able to identify ... '.6 A reviewer of the book observes fairly regarding the 'critical appraisal' of the subtitle that 'Alexander's animus is directed exclusively against the disparagement of Israel issuing from anti-Semites and liberal Diaspora dupes'. ${ }^{7}$

To approach Alexander's perception of John Stuart Mill as a surrogate for modern-day critics of Israel - by which I intend Israeli policy, governmental or civil - requires distinguishing between the facts of the case relating to discrimination against the non-Jewish minority, and desirable 
policy or principles of good governance. For there are those who recognize the justice of the principle of non-discrimination and insist that actual Israeli policy lives up to that principle (or at least tries to do so), as well as those who adopt the same principle but believe that Israeli policy systematically contravenes it - and does so even as a matter of principle. ${ }^{8}$ What though of Mill? Could honest critics find comfort in his stance regarding the principle of equality? Alexander, notwithstanding the formal contrast he draws between Mill and Arnold senior - his assertion that Mill was 'neither anti-Semite nor philo-Semite' - evidently does perceive him as prey to anti-Jewish prejudice, whatever label we might choose to apply, so that his writings could be put to the service of disingenuous critics including Jews of the 'self-hating' variety. By implication, honest critics who (rightly or wrongly) perceive Israeli policy to be discriminatory, or who are concerned by indications that suggest a weakening of the principle of equality embodied in the Declaration of Independence, could scarcely find in him a source of inspiration, for he would be seen as simply hypocritical in his own day when purporting to champion minority rights while in fact biased against Jews.

The evidence I shall bring leaves no doubt that honest critics may rest assured that they are following in Mill's footsteps. Certainly, Mill expressed himself critically regarding the Old Testament, and in Section II I consider his historical evaluation of ethical standards with particular reference to his representation of the document as 'primitive'. This critical view is, however, shown to be heavily qualified in two respects: full-hearted appreciation of the contribution made by the core Mosaic texts to monotheism and, yet more significantly, a remarkably positive perspective on the Prophets. The overall view of historical Judaism is thereby transformed.

My historical overview then proceeds (Section III) to Mill's major qualifications to the notion of ethical progress achieved by Christianity. His criticisms were evenly distributed. But as for social reform more specifically, I show that his animus is directed not against Judaism but primarily against Christianity for its lack of social content, including 'duty to the State', thereby falling short of the morality even 'of the best Pagan nations'. Mill's condemnation of the poisonous form of religious prejudice surrounding the Crucifixion is also relevant.

Mill's stance on the Jewish Question in practice was in any event wholly divorced from his perspective on the Old Testament. Prima facie evidence for this assertion is provided by his accord with the 'compatibility of Judaism with a sterling English character', as one contemporary 
put it, as we shall see. In Section IV, I demonstrate the meaningfulness of this accord by reference to Mill's support for the removal of Jewish political disabilities, revealing that Jewish citizens were to be included, like any other minority, within the utilitarian 'greatest happiness' maximand. Similar applications were made to the issues of public education and Sabbatarian legislation, the latter providing a defence of Saturday as the day of rest for Jews on the grounds of their religious obligation - a defence, incidentally, not applied to the Christian observance of Sunday, for which Mill found no religious justification.

\section{Mill on Judaism and ethical progress}

I call attention first to a private communication by J. S. Mill of 9 September 1842 affirming his accord with F. D. Maurice's 'Moral and Metaphysical Philosophy' (1840), but expecting Maurice to be somewhat taken aback: 'I agree to a much greater extent than you would perhaps suppose, in your view, even of the historical position of the Jews'. ${ }^{9}$ I shall cite one characteristic passage from Maurice that Mill might have had in mind:

A habit of looking rather at the negative than at the positive parts of the Jewish system, its provisions rather than its principles, has prevailed to a great extent among our divines and biblical critics. The vague phrases that it was intended to provide against idolatry, and for the recognition of the Divine Unity, have hindered students from steadily examining these [Mosaic] institutions, and considering what information they give us respecting the grounds of national and social life. Our conviction is, that there can be no clear understanding of the principles of political order, as they existed in Greece and Rome, and as they do exist in modern Europe, until the constitution of this Divine commonwealth is meditated upon in an honest and humble spirit. ${ }^{10}$

Mill then went on to admit having once entertained 'crude notions' regarding the Jews, 'many' of which he had abandoned on encountering Joseph Salvador's L'Histoire des Institutions de Moïse et du Peuple Hébreu (1828): 'I believe I was cured of many of my crude notions about them by the writings of Salvador, a Jew by race and by national feeling, a Frenchman by birth, and a rationalist of the school of [H. E. G.] Paulus ... ' ${ }^{11}$ We note a proviso that Salvador's account was 'somewhat ludicrous in its adaptation of Moses to a Voltairian public and in its attempts to prove 
that the Jews were Constitutional Liberals and utilitarians'. Nevertheless, it was 'so full of strong facts and even arguments that it made a great impression on me when I read it a year or two ago' (1998). Earlier the same year, Mill had written to Gustave d'Eichthal that although Salvador's book had been too much affected by contemporary French events, it had transformed his perceptions:

[I]t has ... thrown much new light upon history \& has made me think in a manner I never expected to do of the Hebrew people \& polity, mais cela se ressent horriblement des quinze dernières années de la restauration - I could hardly help laughing at the manner in which he strains everything to recommend poor Moses to the Constitutional Opposition \& to shew that the Jews were Liberals, political economists \& Utilitarians, and that they had properly speaking no religion, or next to none, \& were altogether à la hauteur de l'époque, worthy sons of the 18 th century. ${ }^{12}$

I know of no other indication by Mill himself of his earlier 'crude' views than that mentioned in the letter of September 1842, but we must take him at his word, including the admission that he had entertained such views until the encounter with Salvador in 1840 or $1841 .{ }^{13}$ As for a residue of prejudice implied in the disavowal, I am inclined to believe that Mill's confession in this regard should not be read literally since one does not normally admit to retaining 'crude notions'. Nevertheless, several of his objections to the Old Testament as a 'primitive' document, even after reading Salvador, do lack balance, while an evident unawareness of centuries - rather, millennia - of rabbinical interpretation constitutes to my mind a serious weakness. To the extent that Mill did retain a biased view in the historical context, I find that his ability to approach the contemporary Jewish question sympathetically - documented later in this paper - to be all the more impressive.

Let me be more specific. In 1835 Mill opined that the 'guidance in the details of ethics' or a 'code of morals' provided by Judaism was but 'local and temporary' rather than universally applicable; ${ }^{14}$ and in later correspondence he strikingly lamented:

How can morality be anything but the chaos it now is, when the ideas of right \& wrong, just \& unjust, must be wrenched into accordance either with the notions of a tribe of barbarians in a corner of Syria three thousand years ago, or with what is called the order of Providence. ${ }^{15}$ 
On Liberty refers to the ethical doctrine of the Bible as 'a system elaborate indeed, but in many respects barbarous, and indeed only for a barbarous people. ${ }^{16}$ Utilitarianism refers to 'the idée mère, the primitive element, in the formation of justice', namely:

conformity to law [which], constituted the entire idea among the Hebrews, up to the birth of Christianity; as might be expected in the case of a people whose laws attempted to embrace all subjects on which precepts were required, and who believed those laws to be a direct emanation from the Supreme Being. ${ }^{17}$

Mill goes on to argue that the Greeks and Romans were more advanced by opening the door for law reform. For they 'knew that their laws had been made originally, and still continued to be made, by men', and so:

were not afraid to admit that those men might make bad laws; might do, by law, the same things, and from the same motives, which, if done by individuals without the sanction of law, would be called unjust. And hence the sentiment of injustice came to be attached, not to all violations of law, but only to violations of such laws as ought to exist, including such as ought to exist but do not; and to laws themselves, if supposed to be contrary to what ought to be law.

What particularly troubled Mill regarding the Hebrew law was the lex talionis or law of retaliation:

when the legitimacy of inflicting punishment is admitted, how many conflicting conceptions of justice come to light in discussing the proper apportionment of punishment to offences. No rule on this subject recommends itself so strongly to the primitive and spontaneous sentiment of justice, as the lex talionis, an eye for an eye and a tooth for a tooth. Though this principle of the Jewish and of the Mahomedan law has been generally abandoned in Europe as a practical maxim, there is, I suspect, in most minds, a secret hankering after it..$^{18}$

Mill was apparently largely unaware of the ethical rulings in the Old Testament of undoubted universal and permanent relevance encapsulated by the seven Noahide commandments enjoined upon all mankind, but in fact extending much further to encompass, for example, fair treatment of 'aliens' - an injunction against the return to their masters of escaped 
slaves - animal welfare and public hygiene. ${ }^{19}$ As for the lex talionis, Mill bases himself on a literal reading of the Biblical text, ignoring rabbinical interpretation that runs in terms of monetary compensation for injury, although admittedly it is no easy matter to discern whether the Rabbis intended to soften the harshness of the original or whether they believed that monetary compensation was the actual intention of the lawgiver. More generally, Mill ignored entirely the fact that social utility was a prime consideration governing the rabbinical contribution to practical Jewish law. ${ }^{20}$

When Mill does recognize aspects of the broader picture, it is sometimes in a manner so ungracious as to suggest prejudice, and to that extent Alexander has reason to object. I refer to a note regarding the commandment 'to love one another' (as found in John), where Mill reminds readers that this is ' $[\mathrm{n}]$ ot, however, a new commandment. In justice to the great Hebrew lawgiver, it should always be remembered that the precept, to love thy neighbour as thyself, already existed in the Pentateuch; and very surprising it is to find it there. ${ }^{21}$ Similarly ungenerous is his declaration that ' $[\mathrm{t}]$ he Stoics were, I believe, the first (except so far as the Jewish law constitutes an exception) who taught as a part of morality that men were bound by moral obligations to their slaves'. ${ }^{22}$ Why the qualification? As for the Jewish law restricting proprietary rights to land, it is hardly the Hebrew lawgiver's fault that in the historical times of the Jewish state this rule may have been successfully evaded'. ${ }^{23}$

Mill himself, we recall, had affirmed in 1842 that he had abandoned 'many' - not all - of his admitted biases regarding the Jews upon encountering Joseph Salvador, so perhaps we should not be surprised to encounter residual instances of prejudice. But we must be cautious, for the fact is that Mill also expressed, simultaneously, fulsome appreciation for the advance of humanity by the ancient Hebrews. Thus, the reflection that their perceiving law as emanating from the Supreme Being and accordingly as necessarily 'just', which precluded any notion of 'the progress of mankind', did not prevent Mill from applauding their contribution to monotheism as such:

We have no wish to dispute the matter with those who believe that Monotheism was the primitive religion, transmitted to our race from its first parents in uninterrupted tradition. By their own acknowledgment, the tradition was lost by all the nations of the world except a small and peculiar people, in whom it was miraculously kept alive. $^{24}$ 
And while regretting the failure of the Hebrews to remain faithful to the principle, ${ }^{25}$ Mill acknowledged that such lapses could be understood as reflecting the real mental difficulties impeding its adoption.

But beyond all this, an admiration for the Hebrew Prophets constitutes a veritable transformation of the view taken of early Judaism if not of the Old Testament. Here Joseph Salvador again plays a part, as is clear from Mill's letter to Gustave d'Eichthal of 10 January 1842, referred to earlier: 'He is quite right ... in saying that the liberty of prophesying was equivalent in the Jewish polity to the liberty of the press \& the point is a new \& striking one. ${ }^{26}$ But Mill insists against Salvador on the specifically religious component, complaining that:

it really is not necessary to tell us that the prophets did not pretend to be, nor were supposed to be, specially credited from God, that all the expressions implying them to be such are a mere façon de parler, meaning only that they were very clever fellows, \& to fortify this by philological arguments from the usages \& phrases of the Hebrew tongue.

It would have been preferable:

to say at once that all persons of genius, inspired persons in the modern sense, poets \& persons of imagination \& eloquence who had great \& wonderful powers not derived from teaching, were believed to derive these powers straight from God \& were in consequence of that religious belief, permitted from religious motives to exercise that right of free speech \& free censure of powerful persons, which certainly would not in that age have been conceded to any one who spoke merely as from himself. ${ }^{27}$

Some 20 years later, Mill confirmed his dismissal of the predictive powers of the still greatly admired Prophets, when those powers are perceived to be supernatural, while again emphasizing the essential role played by religious belief in assuring confidence in the prophetic message. ${ }^{28}$

Going even further than the correspondence are passages from Considerations on Representative Government (1861), where the very character of the Jewish religion is central to the argument. Here, the Prophetic literature is portrayed as a revolutionary breakaway from the Old Testament, and the Jews - along with the Greeks - as 'the starting-point and main propelling agency of modern cultivation'. ${ }^{29}$ 
The context is a contrast between the ancient Chinese and Egyptians, viewed as unable to progress 'for want of mental liberty and individuality' and 'a comparatively insignificant Oriental people - the Jews ... Their religion ... enabled persons of genius and a high religious tone to be regarded and to regard themselves as inspired from heaven, [giving] existence to an inestimably precious unorganized institution - the Order (if it may be so termed) of Prophets' alongside the monarchy and priesthood, an 'antagonism of influences' - a balance of power - which is 'the only real security for continued progress. Religion consequently was not there, what it has been in so many other places - a consecration of all that was once established, and a barrier against further progress'. But Salvador, Mill affirmed, did not go far enough. Though valid, his identification of the Prophets with the modern freedom of the press did not convey:

an adequate conception of the part fulfilled in national and universal history by this great element of Jewish life; by means of which, the canon of inspiration never being complete, the person most eminent in genius and moral feeling could not only denounce and reprobate, with the direct authority of the Almighty, whatever appeared to them deserving of such treatment, but could give forth better and higher interpretations of the national religion, which thenceforth became part of the religion.

A divorce of the Prophets from the earlier Biblical works is a main theme, and a more enthusiastic accolade for the Jewish contribution to civilization it is difficult to imagine:

Accordingly, whoever can divest himself of the habit of reading the Bible as if it was one book, which until lately was equally inveterate in Christians and in unbelievers, sees with admiration the vast interval between the morality and religion of the Pentateuch, or even of the historical books (the unmistakable work of the Hebrew Conservatives of the sacerdotal order), and the morality and religion of the Prophecies: a distance as wide as between these last and the Gospels. Conditions more favourable to progress could not easily exist: accordingly, the Jews, instead of being stationary like other Asiatics, were, next to the Greeks, the most progressive people of antiquity, and, jointly with them, have been the starting-point and main propelling agency of modern cultivation. ${ }^{30}$ 
True, the allusion to a sharp break in ethical progress between the Prophets and the Gospels implies that the Prophets did not go far enough. Yet, as we shall now see, in a range of informal and formal contexts dating from 1835 onwards - On Liberty included - Mill questioned whether the Gospels indeed purveyed a peculiarly Christian morality.

\section{Mill on Christian ethics}

In the course of a defence of the utility doctrine in 1835 against criticisms by Adam Sedgwick (1835), Mill points to Sedgwick's opposing a 'moral sense' to an alleged 'indefiniteness of a morality founded on utility', assuming by the contrast 'his moral-sense man [to be] provided with all the guidance which can be derived from a revelation from heaven intending New Testament revelation - and his "utilitarian" destitute of any such help'. ${ }^{31}$ Revelation, Mill insisted, was in principle also open to the utilitarian 'to assist or rectify our judgments of utility'. But the entire formulation, Mill explains, in an argument distinguishing Christianity from Judaism and other religions, was in fact faulty since there were no specifically Christian guidelines to practical ethics:

Christianity does not deliver a code of morals, any more than a code of laws. Its practical morality is altogether indefinite, and was meant to be so .... Christianity, on the contrary, influences our actions only [1867: influences the conduct] by shaping the character itself: it aims at so elevating and purifying the desires, that there shall be no hindrance to the fulfilment of our duties when recognized; but of what our duties are, at least with regard to outward acts, it says very little but what all moralists [1867: moralists in general] have said [emphasis added].

And in the absence of peculiarly Christian guidelines to practical ethics, "we must perforce resort to that "foresight of consequences", of the difficulties of which the Professor has so formidable an idea'.

In the System of Logic (1843), Judaism is famously perceived as merely a stage in human development in a sequence entailing polytheism, Judaism, Christianity, Protestantism and 'the critical philosophy of modern Europe and its positive science', with each stage perceived as 'a primary agent in making society what it was at each successive period'. ${ }^{32}$ For all that, we yet find reaffirmed in On Liberty - as in 1835 - a denial of anything like 'a complete doctrine' of Christian morals, with the New 
Testament amounting to a sort of wishful-thinking seeking unsuccessfully to go beyond Old Testament morality - it is in this context that we have encountered the representation of the Old Testament as a 'barbarous' production - and in the case of St Paul, accommodating Greek and Roman doctrine including slavery:

[B] efore pronouncing what Christian morality is or is not, it would be desirable to decide what is meant by Christian morality. If it means the morality of the New Testament, I wonder that any one who derives his knowledge of this from the book itself, can suppose that it was announced, or intended, as a complete doctrine of morals. The Gospel always refers to a pre-existing morality, and confines its precepts to the particulars in which that morality was to be corrected, or superseded by a wider and a higher; expressing itself, moreover, in terms most general, often impossible to be interpreted literally, and possessing rather the impressiveness of poetry or eloquence than the precision of legislation. To extract from it a body of ethical doctrine, has never been possible without eking it out from the Old Testament, that is, from a system elaborate enough indeed, but in many respects barbarous, and intended only for a barbarous people. St. Paul, a declared enemy to this Judaical mode of interpreting the doctrine and filling up the scheme of his Master, equally assumes a pre-existing morality, namely that of the Greeks and Romans; and his advice to Christians is in a great measure a system of accommodation to that; even to the extent of giving an apparent sanction to slavery. ${ }^{33}$

What follows in On Liberty certainly undermines the representation in Auguste Comte of Christianity as 'the highest form of Monotheism' (see endnote 32), and indeed negates any notion of ethical progress over the centuries up until Mill's day:

Christian morality (so called) has all the characters of a reaction; it is, in great part, a protest against Paganism. Its ideal is negative rather than positive; passive rather than active; Innocence rather than Nobleness; Abstinence from Evil, rather than energetic Pursuit of Good: in its precepts (as has been well said) 'thou shalt not' predominates unduly over 'thou shalt'. ${ }^{34}$

But there is, in addition, Mill's own vision of a good society reflected in the charge that Christianity encouraged self-interest at the cost of 
social concern, its standard of ethics amounting to no more than 'passive obedience':

It holds out the hope of heaven and the threat of hell, as the appointed and appropriate motives to a virtuous life: in this falling far below the best of the ancients, and doing what lies in it to give human morality an essentially selfish character, by disconnecting each man's feelings of duty from the interests of his fellow-creatures, except so far as a self-interested inducement is offered to him for consulting them. It is essentially a doctrine of passive obedience; it inculcates submission to all authorities found established .... And while, in the morality of the best Pagan nations, duty to the State holds even a disproportionate place, infringing on the just liberty of the individual; in purely Christian ethics, that grand department of duty is scarcely noticed or acknowledged. ${ }^{35}$

These charges against Christianity correspond, be it noted, to those directed at the 'Old School' of political economy, namely opposition to social reform on the grounds of the sanctity of the laissez faire principle, and - citing Cliffe Leslie - of 'pleasing the powers that be, by lending the sanction of "science" to all established institutions and customs, unless, indeed, customs of the poor'. ${ }^{36}$

On Liberty carries yet further the denial of anything amounting to a peculiarly Christian contribution to the idea of public spirit:

What little recognition the idea of obligation to the public obtains in modern morality, is derived from Greek and Roman sources, not from Christian; as, even in the morality of private life, whatever exists of magnanimity, high mindedness, personal dignity, even the sense of honour, is derived from the purely human, not the religious part of our education, and never could have grown out of a standard of ethics in which the only worth, professedly recognised, is that of obedience. ${ }^{37}$

In conclusion, Mill declared:

It can do truth no service to blink the fact, known to all who have the most ordinary acquaintance with literary history, that a large portion of the noblest and most valuable moral teaching has been the work, not only of men who did not know, but of men who knew and rejected, the Christian faith. ${ }^{38}$ 
This orientation, it must be said, is itself qualified, although without changing the general picture. Thus, in 'Utility of Religion', Mill:

grant[ed] that some of the precepts of Christ as exhibited in the Gospels - rising far above the Paulism which is the foundation of ordinary Christianity - carry some kinds of moral goodness to a greater height than had ever been attained before, though much even of what is supposed to be peculiar to them is equaled in the Meditations of Marcus [Aurelius] Antoninus, which we have no ground for believing to have been in any way indebted to Christianity. ${ }^{39}$

A final matter contributing to our understanding of Mill's perspective on Christianity especially in relation to the Jews is his reading of the Crucifixion. Thus, On Liberty mitigates the moral responsibility of those responsible for the 'judicial iniquity'. ${ }^{40}$ Mill pleaded for a judgement taking proper account of time and place:

The high-priest who rent his garments when the words were pronounced, which, according to all the ideas of his country, constituted the blackest guilt, was in all probability quite as sincere in his horror and indignation, as the generality of respectable and pious men now are in the religious and moral sentiments they profess; and most of those who now shudder at his conduct, if they had lived in his time, and been born Jews, would have acted precisely as he did. ${ }^{41}$

\section{Contemporary issues}

\section{i. Parliamentary reform}

I now turn from Mill's perspective on the historical development of ethical standards to contemporary policy, starting with parliamentary reform. In 'Notes on the Newspapers' for the Monthly Repository of 17 June 1834, Mill designated as a 'Parliamentary Monstrosity' the stance adopted in the House of Lords by Edward Grey (Bishop of Hereford and brother of the Prime Minister) in rejecting an Edinburgh petition for the removal of Jewish Civil Disabilities. ${ }^{42}$ The Socinians ${ }^{43}$ - tolerated by the legislature - Grey held 'in utter abhorrence', but at least they believed Jesus to be the Messiah, 'while the Jews affirmed the Lord Jesus Christ to be an imposter'. Mill protested strongly: 
Protect us from such Christianity! If this be the figure under which Christianity is to continue to be exhibited by its recognized teachers, there needs no prophet to predict, that, as the religion of the people of this country, it will not last two more generations. The religion which men shall ever again reverence, and shape their lives by, will be, Dr. Grey may depend on it, another kind of religion than this.

In this protest we have an early affirmation that there were no valid religious grounds for maintaining the political disabilities imposed on members of the Jewish faith.

In further comments in the Monthly Repository (12 August 1834), Mill denounced the rejection by the House of Lords of the Jewish Emancipation Bill, and now extended his criticisms to the rejection of two further proposals from the lower House: a Bill 'to Remove Certain Disabilities Which Prevent Some Classes of His Majesty's Subjects from Resorting to the Universities' - which of course included Jewish subjects - and a Bill 'to Abolish the Irish Tithe'. ${ }^{44}$ Mill's case regarding the first two is made out on the grounds of the principle of 'civil equality and religious liberty', in line with the June article, although he had no illusions about the potential effectiveness of the first two rejected bills. It is unclear whether by his assertion that the 'Jew Bill' or the 'Universities' Admission Bill', if carried, would have entailed not 'one atom of practical good', Mill intended the small number of those potentially affected or an estimate that very few would take advantage of liberalization, but it is clear that what mattered for him was the principle of 'civil equality and religious liberty', which does not turn on numbers. ${ }^{45}$

Mill's firm support for the removal of Jewish political disabilities remained unqualified thereafter. In 1848 and again in 1849, Lord John Russell's Jewish Disabilities Bill designed to admit Jews to parliament was turned back by the House of Lords. Writing to Harriet Taylor, Mill protested:

Do you notice that Russell in bringing forward his Jew Bill, although he is actually abolishing the old oaths \& framing new, still has the meanness to reinsert the words 'on the true faith of a Christian' for all persons except Jews, \& justifies it by saying that the Constitution ought not avowedly to admit unbelievers into Parliament. ${ }^{46}$

This is evidently not a remark hostile to the release of Jews from an oath impeding their entry into the legislature, but rather a protest at the 
refusal to extend the release to all and sundry. The matter was elaborated anonymously in an article of 26 March 1849 for the Daily News - entitled 'The Attempt to Exclude Unbelievers from Parliament' - summarized by Mill as declaring 'without mincing the matter, that infidels are perfectly proper persons to be in parliament'. ${ }^{47}$ Mill assured Harriet - who had encouraged him to write an article on Russell's Bill - that 'I have carefully avoided anything disrespectful to Russell personally', but this is unconvincing, for the article effectively charges Russell with unprincipled political calculation:

He is proposing to abolish the old oaths and to establish new, and in the oaths which he establishes he introduces de novo these very words, granting to Jews a special exemption from their use. He opens the door of parliament just wide enough to allow in one particular class of dissenters from Christianity to slip in, and closes it, as far as depends upon him, against all others. ${ }^{48}$

Not only religious sceptics would be excluded, Mill pointed out, but some three-quarters of the population of the Empire professing beliefs other than Christianity, radically restricting the pool of parliamentary talent. ${ }^{49}$ But Mill could not bring himself to believe that Russell actually intended to exclude those formally affected. His true purpose, Mill deduces, was not to exclude sceptics and other non-Christians, but to attract voters to his party by allowing into the Commons Lionel de Rothschild, who was returned as Liberal candidate in 1847 for the City of London but unable to take his seat because of the required oath 'on the true faith of a Christian'. ${ }^{50}$ As in 1834 , practical effectiveness was secondary to mankind's improvement: '[Russell] has yet to learn that a legislature which either introduces or confirms a bad principle does more harm than is compensated by twenty good practical measures involving no principle: for it is by the principles contained in them that institutions educate the national mind'. ${ }^{51}$

Five years later, Mill reaffirmed his support for the removal of the restriction on Jews, and this notwithstanding his objection to the procedure adopted by the proposed legislation: ' $\ldots$ the writer of one of the leading articles in today's Morning Post [14 March 1854] had evidently come hot from reading the Logic, \& I am sorry to say did it no credit as a pupil for it was an article against the Jew bill'. ${ }^{52}$ As Mill's editors explain, the objectionable article 'ended with an attack on a writer in Fraser's for attempting to prove the "compatibility of Judaism with a sterling English character". Mill's insistence upon such compatibility has been sufficiently demonstrated..$^{53}$ 
There is one qualification to be noted. Addressing the electors of Westminster on 2 November 1868, Mill played down the importance of the 'admission of Jews to equal power with other people' - finally achieved in legislation of 1858 and 1866 regarding the Commons and Lords respectively - and similarly 'the abolition of the church rates' achieved in $1868 .{ }^{54}$ But both cases he intended 'comparatively unimportant' relative to parliamentary reform itself - Disraeli's great Reform Act had been passed the previous year - and by no means a positive denigration of the significance of the issues.

\section{ii. Public education}

Mill's support for secular public education is based on the same considerations of 'civil equality and religious liberty', cited above, as those for the removal of Jewish political disabilities:

To know the laws of the physical world, the properties of their own bodies and minds, the past history of their species, is as much a benefit to the Jew, the Musselman, the Deist, the Atheist, as to the orthodox churchman; and it is iniquitous to hold it from them. Education provided by the public must be education for all, and to be education for all it must be purely secular education. ${ }^{55}$

As for public education limited to believers in New Testament doctrine:

The Jew and the unbeliever would be excluded from it though they would not the less be required to pay for it. I do not hear that their money is to be refused, that they are to be exempted from the school rate. Religious exclusion and inequality are as odious when practised towards minorities as majorities [emphasis added].

In later correspondence, Mill consistently argued against clauses in the 1870 Education Bill that he feared would 'empower the State to establish schools on the denominational principle. ${ }^{56}$ And in a public speech he strongly reaffirmed his opposition to Church of England teaching funded by the state: 'The principle remains of teaching the religion of a part with funds raised by taxation from the whole; and a measure infected by this bad principle cannot be satisfactory to any but persons of the dominant creed, not to impartial persons of any creed. ${ }^{57}$ 
There is in fact one case where Mill justifies particular protection of Jewish religious sensibilities. I have in mind his position in On Liberty regarding Sabbatarian legislation, a category that might seem less important than voting rights and public education, but which strikingly confirms the absence of hostile bias on Mill's part in practical application. Thus, the state should in its Sabbatarian legislation protect the sanctity of Saturday for Jews, whereas any other day might be selected as a day of rest for non-Jews: 'Without doubt, abstinence on one day in the week, so far as the exigencies of life permit, from the usual daily occupation, though in no respect religiously binding on any except Jews, is a highly beneficial custom ... ${ }^{58}$ Should Sunday - or any other day - be selected as the general day of rest there would necessarily be exceptions - such as workers in a variety of service industries including cultural activities, transportation and the like; but restrictions on Sunday amusements on purely religious grounds reflected 'a determination not to tolerate others in doing what is permitted by their religion, because it is not permitted by the persecutor's religion. It is a belief that God not only abominates the act of the misbeliever, but will not hold us guiltless if we leave him unmolested'. Mill's rejection of a religious basis for Sunday observance, coupled with his defence of the Jewish Sabbath, is reiterated in electioneering for the Westminster constituency on 8 July 1865: 'his opinion was that the Sabbatical institution was an institution for the Jews only. The Christian Sunday appeared to him to be an institution of a quite different character. ${ }^{59}$

\section{Summary and conclusion: a current application}

The notion that Mill was prejudiced against Judaism turns in large part on his observations regarding the historical progression of ethical standards. This progression we have shown was subject to major qualification. Thus, his declamations regarding 'primitive' Old Testament doctrine based upon a partial familiarity with the text - are effectively outweighed by his admiration for the Prophetic institution represented as protecting freedom of critical expression against perceived injustices as essential to assure their correction to the benefit of the state. In any event, it is clear that several of his hostile remarks relating to religion are directed at 
Christian rather than Jewish targets; indeed, in one case, a representation of the Old Testament as 'primitive' is expressed in the context of a criticism of contemporary Christianity (see above). Certainly, charges of lack of social concern and endemic conservatism had profound consequences for the broadest range of contemporary social issues. Furthermore, Mill's understanding of ancient Jewish history in no way deflected him from the principle of equality implying protection of Jewish civil rights in contemporary England on a par with those of other minorities. The abolition of Jewish political disabilities is a prime case in point, with Mill opposing John Russell's exclusion of Jews from the Christian oath for entry into parliament only because it discriminated against other non-Christians including atheists and agnostics. The case for non-denominational public education is similarly based on the principles of 'civil equality and religious liberty'. Particularly significant as evidence of a fearless objectivity is the argument for recognition of Saturday as the day of rest for Jews on specifically religious grounds (but not of Sunday for non-Jews). Here satisfaction of the principle of 'equality' is seen as justifying in special cases a sort of positive discrimination.

Recall now, from the outset of this paper, Thomas Arnold's crude lambasting in 1834 of 'that low Jacobinical notion of citizenship, that a man acquires a right to it by the accident of his being littered inter quatuor maria or because he pays taxes', a stance he directed against the Jewish minority of his day. It is precisely a Jacobinical notion of citizenship - a term corresponding to 'left-wing' in today's parlance - that Mill upheld and which he would doubtless apply today to the benefit of other minorities. Honest critics of specific policies adopted by the modern Jewish state (elaborated below) should therefore feel free to appeal to Mill in good conscience.

Now, ethical objections to discrimination are of course strengthened where inequality in the treatment of majorities by the minority is at issue; and Mill indeed appropriately extended his case. A concept of 'national morality' is of the essence in his treatment of British colonial rule in Ireland and India. ${ }^{60}$

As for Ireland, Mill considered reducing unrest by improving the lot of the Irish, including a variety of land reforms, but he recognized a 'desperate form of dissatisfaction, which does not demand to be better governed, which asks us for no benefit, no redress of grievances, not even any reparation of injuries, but simply to take ourselves off and rid the country of our presence' - that is, a 'revolt of mere nationality' ${ }^{61}$ He himself could not have believed that the situation had quite reached that stage since he put much weight on institutional reform as a last resort to save the Union. Only in its absence would Britain be forced, and rightly so, to abandon Ireland: 
It is not consistent with self-respect, in a nation any more than an individual, to wait till it is compelled by uncontrollable circumstances to resign that which it cannot in conscience hold. Before allowing its government to involve it in another repetition of the attempt to maintain dominion over Ireland by brute force, the English nation ought to commune with its conscience, and solemnly reconsider its position. If England is unable to learn what has to be learnt, and unlearn what has to be unlearnt, in order to make her rule willingly acceptable by the Irish people ... are we the power which, according to the general fitness of things and the rules of morality, ought to govern Ireland. ${ }^{62}$

As for India, the following extract from Considerations on Representative Government is written with an eye to the East India Company:

The government of a people by itself has a meaning, and a reality; but such a thing as government of one people by another does not and cannot exist. One people may keep another as a warren or preserve for its own use, a place to make money in, a human cattle-farm, to be worked for the profit of its own inhabitants. But if the good of the governed is the proper business of a government, it is utterly impossible that a people should directly attend to it. The utmost they can do is to give some of their best men a commission to look after it; to whom the opinion of their own country can neither be much of a guide in the performance of their duty, nor a competent judge of the mode in which it has been performed. ${ }^{63}$

I stress in particular the qualification that if the good of the governed is the proper business of a government' then the 'government of one people by another does not and cannot exist'. For since 1967 Israel has exercised rule over a subject people making use of administrative, legal, police and military regulations, much of which was inherited from Mandatory times when Britain was the occupying power. In some respects, matters are worse than Mill would have feared. Public opinion in Israel apparently has no patience with Millian liberal principles, which is scarcely surprising since the attitudes of administrators, police, soldiers and settlers in the Territories naturally affect the perspectives of residents within the Green Line - in many, perhaps in most, cases these are in fact overlapping groups. But beyond this, Palestinians are allowed no access to independent commissioners divorced from Israeli public opinion of the sort Mill believed was provided by the East India Company concerned with Indian welfare. 
Now, Mill's 'Jacobinism' is in fact expressed loud and clear in Israel's Declaration of Independence, in the famous clause stating that the Jewish State 'will ensure complete equality of social and political rights to all its inhabitants irrespective of religion, race or sex'. ${ }^{64}$ The now widespread condemnation as 'traitors' to the Jewish State of critics concerned with perceived deviations from this principle amounts to rejection of the founding document. Indeed, the Nation-State Law passed in September 2018 (and at the time of writing before the High Court) omits entirely mention of equal treatment of minorities and is thus conspicuously at odds with the Declaration of Independence. Worse still, the principle of non-discrimination is explicitly traced in that document to 'the prophets of Israel', so that if we accept Mill's view of the prophetic institution as one establishing the right 'to denounce and reprobate' - under religious auspices into the bargain - it follows that those who would silence criticism do so in the name of a sadly impoverished version of the Jewish faith. They bear an exceedingly heavy responsibility.

\section{Notes}

1. Edward Alexander, The State of the Jews: A Critical Appraisal (New Brunswick and London: Transaction Publishers, 2012), xiv.

2. Referring to the Jewish Emancipation Bill rejected by the House of Lords in 1833 and reintroduced unsuccessfully in 1834. The proposed legislation included the release of Jews elected to parliament from the obligation to take a Christian oath before taking their seats.

3. Literally: within the four seas. Arnold's ultimate objective was to avoid an 'indiscriminate mixture' of races; see Arthur P. Stanley, The Life and Correspondence of Thomas Arnold, D.D., I (London: B. Fellowes, 1844), 378. He was willing, he explains to another correspondent, to let Jews 'tax themselves in a Jewish House of Assembly, like a colony or like the clergy of old; but to confound the right of taxing oneself with the right of general legislation, is one of the Jacobinical confusions of later days, arising from those low Warburtonian notions of the ends of political society' (377-8n). (Regarding Henry Warburton, Radical MP, see Mill's favourable comment in the Examiner, 2 September 1832; John Stuart Mill [1832], 'Recommendations of Candidates to Parliament' [2 September 1832], in Newspaper Writings, Collected Works [hereafter, CW] [Toronto: University of Toronto Press, 1986], XXIII, 507.)

4. Cited in Stanley, The Life and Correspondence of Thomas Arnold, D.D., 377.

5. Alexander, The State of the Jews, xiii-xiv.

6. Alexander, The State of the Jews, xiv.

7. Haim Chertok, 'Review of Alexander', Hadassah (August-September 2013): 69.

8. Much of my discussion identifies the principle of equality with non-discrimination against minorities. The moral issue is of course exacerbated where the 'colonialist' treatment of majorities by the minority is entailed.

9. John Stuart Mill, The Later Letters 1849 to 1873, CW, XIV-XVII (1997).

10. Frederick D. Maurice (1840), 'Moral and Metaphysical Philosophy', in Encyclopaedia Metropolitana, eds. E. Smedley et al. (London: Joseph Griffen, 1849), Vol. II, 545-674, 554. This positive view is carried further in analysis of the Prophetic Period; see John Stuart Mill (1849), 'The Attempt to Exclude Unbelievers from Parliament' (26 March), in Newspaper Writings, CW, XXV, 560-7.

11. Mill, Later Letters, CW, XIV-XVII (1997-8).

12. John Stuart Mill, The Earlier Letters 1812 to 1848, CW, XII-XIII (1963), (10 January 1842), 496. 
13. For the importance of Salvador as an influence on Mill, particularly regarding the Prophetic literature, see Georgios Varouxakis, Liberty Abroad: J. S. Mill on International Relations (Cambridge: Cambridge University Press, 2013), 112.

14. John Stuart Mill (1835), 'Sedgwick's Discourse', in Essays on Ethics, Religion and Society, CW, X (1985), 65.

15. Mill, Later Letters, 22 November 1850, CW, XIV-XVII, 53.

16. John Stuart Mill (1859), On Liberty, CW, XVIII (1977), 254-5.

17. John Stuart Mill (1861), Utilitarianism, in Essays on Ethics, Religion and Society, CW, X (1969), 245.

18. Mill, Utilitarianism, 253.

19. Indeed, we have seen that Salvador's account elicited mockery on Mill's part.

20. Salvador, who alludes frequently to utilitarian considerations in discussing the Old Testament, does not consider rabbinical literature.

21. John Stuart Mill (1874), 'Utility of Religion', in Three Essays on Religion. Essays on Ethics, Religion and Society, CW, X (1969), 416 (written between 1850 and 1858); emphasis added.

22. John Stuart Mill (1869), The Subjection of Women. In Essays on Equality, Law, and Education, CW, XXI (1984), 266.

23. John Stuart Mill (1879), Chapters on Socialism. In Essays on Economics and Society, CW, V (1967), 751.

24. John Stuart Mill (1865), Auguste Comte and Positivism. In Essays on Ethics, Religion and Society, CW, X (1969), 274; emphasis added.

25. See also Mill, 'Utility of Religion', 412, 421, on the tendency of the Hebrews to lapse from their worship.

26. Mill, Earlier Letters, 496.

27. Mill, Earlier Letters, 496-7; emphasis added.

28. Mill, Later Letters, to Henry Chenevix (4 November 1863), 895-6.

29. John Stuart Mill (1861), Considerations on Representative Government, in Essays on Politics and Society, CW, XIX (1977), 397.

30. Mill, Considerations on Representative Government, 397.

31. Mill, 'Sedgwick's Discourse', 65.

32. John Stuart Mill (1843), A System of Logic Ratiocinative and Inductive, CW, VII-VII (1974), 927. The transition was a complex process, with Mill affirming subsequently that '[i]n whatever mode, natural or supernatural, we choose to account for the early Monotheism of the Hebrews, there can be no question that its reception by the Gentiles was only rendered possible by the slow preparation which the human mind had undergone from the philosophers' (Mill, Comte and Positivism, 275). And there were reversals insofar as even 'the highest form of Monotheism, Christianity' had, up to Mill's time, 'giv[en] partial satisfaction to the mental dispositions that lead to Polytheism, by admitting into its theology the thoroughly polytheistic conception of a devil' (274).

33. Mill, On Liberty, 254-5.

34. Mill, On Liberty, 255.

35. A silent objection to the ethical stance of William Paley might be intended here, at least if we follow Mill's interpretation of Paley as provided in 'Sedgwick's Discourse': 'Paley not only represents the proposition that we ought to do good and not harm to mankind, as a mere corollary from the proposition that God wills their good, and not their harm - but represents the motive to virtue, and the motive which constitutes it virtue, as consisting solely in the hope of heaven and the fear of hell' (see Mill, 'Sedgwick's Discourse', 53-4). That God wills conduct directed at enhancing the general good, thereby furthering happiness, is a feature of Lockean ethical doctrine; but Locke's 'theological utilitarianism' had its limits and did not extend to the second element of Mill's reading of Paley.

36. John Stuart Mill (1870), 'Leslie on the Land Question', in Essays on Economics and Society, CW, V (1967), 671; see Samuel Hollander, John Stuart Mill: Political Economist (Singapore: World Scientific, 2015), 434-6.

37. Mill, On Liberty, 256. Mill here evaluates the Koran as superior to the New Testament in recognizing competence as the criterion in selecting state officials, an index of social responsibility.

38. Mill, On Liberty, 257.

39. Mill, 'Utility of Religion', 416.

40. Mill, On Liberty, 235

41. Mill, On Liberty, 236. 
42. John Stuart Mill (1834), 'Notes on the Newspapers' (17 June), in Essays on England, Ireland, and the Empire, CW, VI (1982), 251.

43. A doctrine denying the divinity of Jesus, the Trinity, etc. and explaining sin and salvation rationalistically.

44. John Stuart Mill (1834), 'Notes on the Newspapers' (12 August), CW, VI (1982), 276.

45. The important contribution to the Jewish relief campaign by Richard Whately, Archbishop of Dublin, to the Lords debate in 1833 and for two decades thereafter is spelled out in Tony Hammond, 'F. H. Goldsmid and Archbishop Whately of Dublin: Their Significance in the Emancipation Debate', Jewish Historical Studies 35 (1996-1998): 153-66. Mill, to my knowledge, makes no mention of Whately in the present context.

46. Mill, Later Letters, 21 February 1849, 13.

47. Mill, Later Letters, 17 March 1849, 18.

48. Mill, 'The Attempt to Exclude Unbelievers', 1136.

49. Mill, 'The Attempt to Exclude Unbelievers', 1137.

50. Mill, 'The Attempt to Exclude Unbelievers', 1137-8. Mill is attributing to Russell a high expectation that Rothschild would be chosen as MP by the London establishment. Rothschild was indeed elected in 1847, and on several occasions thereafter, but was unable to take his seat until the Jews Relief Act of 1858. Only in 1866 were Jews admitted to the House of Lords. On the 1847 election itself, see the account by Victor Gray, 'New Light on the 1847 Election in the City of London', https://www.rothschildarchive.org/materials/review_2010_2011_ new_light_on_the_1847_election_2.pdf (accessed 1 March 2019). For an overview of the civil rights of English Jews in general, see Henry S. Q. Henriques, 'The Civil Rights of English Jews', The Jewish Quarterly Review 18/1 (1905): 40-83.

51. Mill, 'The Attempt to Exclude Unbelievers', 1138.

52. Mill, Later Letters, 185.

53. Mill, Later Letters, $185 \mathrm{n}$. On Jews as a moral threat, as perceived by Thomas Carlyle and his follower Charles Kingsley, see David Levy, How the Dismal Science Got Its Name: Classical Economics and the Ur-Text of Racial Politics (Ann Arbor: The University of Michigan Press, 2001), 73-6, 143, 149-52. By contrast, William Hazlitt in 1831 had argued posthumously against the notion of the Jew as ill-equipped by character to fulfil the conditions for full citizenship (see Hammond, 'Goldsmid and Archbishop Whately of Dublin', 157). Mill does not mention Hazlitt in our context.

54. John Stuart Mill (1868), 'Westminster Election 1868', in Public and Parliamentary Speeches, CW, XXVIII (1988), 337.

55. John Stuart Mill, 'Secular Education', written after 4 November 1850, paper not delivered, in Public and Parliamentary Speeches, CW, XXVIII, 4.

56. Mill, Later Letters, 28 February 1870, 1703.

57. John Stuart Mill (1870), 'The Education Bill', in Public and Parliamentary Speeches, CW, XXIX (1988), 382. On the general context, see Hollander, John Stuart Mill, 505-8. Regarding Mill's opposition to an educational system in Ireland entirely controlled by the Catholic Church, see Bruce L. Kinzer, A. P. Robson and J. M. Robson, A Moralist in and out of Parliament: John Stuart Mill at Westminster. 1865-1868 (Toronto: University of Toronto Press, 1992), 156n.

58. Mill, On Liberty, 289.

59. John Stuart Mill (1865), 'Westminster Election 1865', in Public and Parliamentary Speeches, CW, XXVIII, 38.

60. The same concept is adopted by Ricardo in rejecting proposals to default on the national debt: 'With a view to wealth only, it might be equally or more desirable that [a debtor] should or should not pay it; but the claims of justice and good faith, a greater utility, are not to be compelled to yield to those of a less .... . A debt guaranteed by the nation, differs in no respect from the above transaction. Justice and good faith demand that the interest of the national debt should continue to be paid, and that those who have advanced their capitals for the general benefit, should not be required to forego their equitable claims, on the plea of expediency.' See David Ricardo (1817), Principles of Political Economy, ed. P. Sraffa (Cambridge: Cambridge University Press, 1951), 245-6.

61. John Stuart Mill (1868), England and Ireland, CW, VI (1982), 509-11.

62. Mill, England and Ireland, 519-20; emphasis added.

63. Mill, Considerations on Representative Government, 569; emphasis added.

64. 'THE STATE OF ISRAEL will be open for Jewish immigration and for the Ingathering of the Exiles; it will foster the development of the country for the benefit of all its inhabitants; it will 
be based on freedom, justice and peace as envisaged by the prophets of Israel; it will ensure complete equality of social and political rights to all its inhabitants irrespective of religion, race or sex; it will guarantee freedom of religion, conscience, language, education and culture; it will safeguard the Holy Places of all religions; and it will be faithful to the principles of the Charter of the United Nations.'

\section{Bibliography}

Alexander, Edward. The State of the Jews: A Critical Appraisal. New Brunswick and London: Transaction Publishers, 2012.

Chertok, Haim. 'Review of Alexander', Hadassah (August-September, 2013): 69.

Gray, Victor. 'New Light on the 1847 Election in the City of London'. https://www.rothschildarchive.org/materials/review_2010_2011_new_light_on_the_1847_election_2.pdf (accessed 1 March 2019).

Hammond, Tony. 'F. H. Goldsmid and Archbishop Whately of Dublin: Their Significance in the Emancipation Debate', Jewish Historical Studies 35 (1996-1998): 153-66.

Henriques, Henry S. Q. 'The Civil Rights of English Jews', The Jewish Quarterly Review 18/1 (1905): 40-83.

Hollander, Samuel. John Stuart Mill: Political Economist. Singapore: World Scientific, 2015.

Kinzer, Bruce L., Robson, A. P. and Robson, J. M. A Moralist in and out of Parliament: John Stuart Mill at Westminster. 1865-1868. Toronto: University of Toronto Press, 1992.

Levy, David. How the Dismal Science Got Its Name: Classical Economics and the Ur-Text of Racial Politics. Ann Arbor: The University of Michigan Press, 2001.

Maurice, Frederick D. (1840). 'Moral and Metaphysical Philosophy'. In Encyclopaedia Metropolitana, edited by E. Smedley et al., Vol. II, 545-674. London: Joseph Griffen, 1849.

Mill, John Stuart (1849). 'The Attempt to Exclude Unbelievers from Parliament' (26 March). In Newspaper Writings. Collected Works [CW], XXV, 1135-8. Toronto: University of Toronto Press, 1986.

Mill, John Stuart (1865). Auguste Comte and Positivism. In Essays on Ethics, Religion and Society. $C W, \mathrm{X}, 261-368$ (1969).

Mill, John Stuart (1879). Chapters on Socialism. In Essays on Economics and Society. CW, V, 703-53 (1967).

Mill, John Stuart (1861). Considerations on Representative Government. In Essays on Politics and Society. CW, XIX, 371-577 (1977).

Mill, John Stuart. The Earlier Letters 1812 to 1848. CW, XII-XIII (1963).

Mill, John Stuart (1870). 'The Education Bill'. In Public and Parliamentary Speeches. CW, XXIX, 381-6 (1988).

Mill, John Stuart (1868). England and Ireland. CW, VI, 505-32 (1982).

Mill, John Stuart. The Later Letters 1849 to 1873. CW, XIV-XVII (1972).

Mill, John Stuart (1870). 'Leslie on the Land Question'. In Essays on Economics and Society. CW, V, 668-85 (1967).

Mill, John Stuart (1834). 'Notes on the Newspapers' (17 June). In Essays on England, Ireland, and the Empire. CW, VI, 251-4 (1982).

Mill, John Stuart (1834). 'Notes on the Newspapers' (12 August). CW, VI, 276-7 (1982).

Mill, John Stuart (1859). On Liberty. CW, XVIII, 213-310 (1977).

Mill, John Stuart (1848). Principles of Political Economy. CW, II-III (1965).

Mill, John Stuart (1832). 'Recommendations of Candidates to Parliament' (2 September 1832). In Newspaper Writings. CW, XXIII, 507-9.

Mill, John Stuart. 'Secular Education'. Written after 4 November 1850, paper not delivered. In Public and Parliamentary Speeches. CW, XXVIII, 3-5 (1988).

Mill, John Stuart (1835). 'Sedgwick's Discourse'. In Essays on Ethics, Religion and Society. CW, X, 31-74 (1985).

Mill, John Stuart (1869). The Subjection of Women. In Essays on Equality, Law, and Education. CW, XXI, 259-340 (1984).

Mill, John Stuart (1843). A System of Logic Ratiocinative and Inductive. CW, VII-VII (1974).

Mill, John Stuart (1861). Utilitarianism. In Essays on Ethics, Religion and Society. CW, X, 203-59 (1969). 
Mill, John Stuart (1874). 'Utility of Religion', Three Essays on Religion. In Essays on Ethics, Religion and Society (written between 1850 and 1858). CW, X, 369-489 (1969).

Mill, John Stuart (1865). 'Westminster Election 1865 In Public and Parliamentary Speeches. CW, XXVIII, 31-40 (1988).

Mill, John Stuart (1868). 'Westminster Election 1868'. In Public and Parliamentary Speeches. CW, XXVIII, 334-41 (1988).

Ricardo, David (1817). Principles of Political Economy . Edited by P. Sraffa. Cambridge: Cambridge University Press, 1951.

Salvador, Joseph. Histoire des Institutions de Moïse, et du Peuple Hébreu I. Paris: Ponthieu, 1828.

Stanley, Arthur P. The Life and Correspondence of Thomas Arnold, D.D., I. London: B. Fellowes, 1844.

Varouxakis, Georgios. Liberty Abroad: J. S. Mill on International Relations. Cambridge: Cambridge University Press, 2013. 


\section{4 \\ The Failure of Planned Happiness: The Rise and Fall of British Home Colonies}

Barbara Arneil

In nineteenth-century Britain, many progressive thinkers of various political and religious stripes (socialist, liberal, Protestant, Quaker and humanist) proposed home colonies as a single solution to an enormous variety of social 'problems' (pauperism/idleness, mental disability or illness, alcoholism, juvenile delinquency and/or petty crime) that had beset a rapidly urbanizing and industrializing society. Home colonies in Britain - and more broadly domestic colonies in Europe ${ }^{1}$ - proposed and/or implemented by philanthropic individuals or organizations and states in nineteenth- and early twentieth-century Europe were located inside the borders of one's own state (rather than overseas) in order to segregate the 'idle and/or irrational' of society, engage them in agrarian labour on uncultivated soil and thus ultimately improve both themselves and the land on which they laboured. It was argued that such colonies would transform the marginalized of Britain and shift them from a life of misery, dependence and idleness into one characterized by productivity, independence and happiness.

One can identify three general categories of home colonies based on what they were called by their defenders and the populations to be transformed within them: 1 . farm colonies for mentally ill and disabled people ${ }^{2} 2$. labour colonies for the idle poor and unemployed; ${ }^{3}$ 3. utopian colonies for political, religious and racial minorities. The historical existence of such colonies challenges the meaning of colonization and colonies found in both popular dictionaries and academic analysis, which, by definition, can exist only overseas as products of a foreign policy 
of imperialism. While imperial colonies are certainly the most profound, extensive and longest-lasting kind of colonization as manifestations of imperial power exercised over foreign, often racialized, peoples and lands, in this chapter I show that colonies also existed within Europe for certain kinds of Europeans but that they were justified by a similar ideology of colonialism as had first been used to justify overseas settler colonies. As such, home colonies in Britain were not the product of foreign policy but rather domestic social policy that used colonialism but turned inwards to solve the 'problem' of marginalized populations by virtue of their lack of reason or idleness at home. Many of those who proposed such colonies in Britain argued they would create happiness within these groups of fellow citizens who lived miserable lives on city streets. Home colonies require us to rethink, in interesting ways, the definition and scope of colonization as well as its relationship to happiness within Britain in the nineteenth century.

Colonialism, as an ideology, was characterized by three principles: segregation, improvement and - above all - agrarian labour. First deployed by John Locke in seventeenth-century America to justify the dispossession of indigenous land, ${ }^{4}$ these same principles were adopted by nineteenth- and twentieth-century European domestic colonialists but often married to either a utilitarian or consequentialist understanding of happiness. Thus, the argument was made, in both cases, that rather than conquer, constrain or punish the 'idle' poor or mentally disabled/ill (as current institutions such as asylums, workhouses or prisons did), the home colonialist argued that to segregate such populations from society, cities and the bad habits of their environment, and engage them in agrarian labour on uncultivated soil, would both improve the individual (the ethical benefit) and create revenues through the sale of agricultural produce (the economic benefit). The former would lead to happiness and the latter would offset the growing costs to the state or philanthropist of maintaining such populations. Defenders of the colony model thus explicitly defended colonies against prisons, asylums, workhouses and/ or emigration as both creating better lives for those living within them and being less costly.

Thus, for the purposes of this volume, it is striking how often justifications for nineteenth-century labour or home colonies for the idle poor used happiness to describe the goal of the colony juxtaposed against the misery of both their current state of unemployment, alcoholism, corruption or criminality as well as the life they would face in alternative institutions such as prisons or workhouses or through emigration. Indeed, British home colonies were more often than not described in a highly 
elevated, romantic and sometimes religious language of a 'promised land' of happiness through which the idle poor were 'delivered' from lives of abject misery and redeemed by working the soil in the fresh air of the bucolic countryside, leading them eventually to more virtuous, industrious and happy lives. For British domestic colonialists, the key to producing happiness for the most marginalized and destitute of Britain was not only that the colony was built upon the three key colonial principles of segregation, improvement and agrarian labour, but that life within the colony followed very specific plans or blueprints. Thus, the colony represented planned happiness, meaning that everything from the kinds of buildings to be erected to how the buildings were placed in relation to each other, to the crops grown, to the daily schedule were provided in detailed plans by home colonialists.

Ultimately, it was argued, to achieve happiness for the idle poor, home colonies had to be implemented in accordance with these various detailed plans. The corollary point, often made explicitly by home colonialists, was that if colonies were not created in accordance with the blueprints provided, misery would continue to reign. However, despite the promises made by British domestic colonialists in their written defences of specific kinds of home colonies that planned happiness for the poor could not fail, the historical reality across the board was quite the opposite. Either colonies failed immediately and never got off the ground at all, or they collapsed quickly and spectacularly and/or deteriorated into places that were punitive and/or abusive. In other words, the home colony as the solution to poverty in nineteenth-century Britain was followed almost universally and fairly rapidly by failure, as lofty notions of planned happiness in theory gave way to the profound failure of the colony model in practice.

In this paper, therefore, I examine the rise and fall of home colonies in Britain - the promise of happiness (the rise) based on both the principles of colonialism as described above and in accordance with a detailed plan by various domestic colonialists in Britain, and the failure (the fall) to deliver in practice through three case studies of British domestic colonies and colonialists:

1. Utopian home colonies for the poor proposed by Robert Owen in Britain in 1840 .

2. Labour colonies proposed and created in Lindfield, Sussex, by William Allen in 1827.

3. Labour farm colonies proposed and created by the founder of the Salvation Army, William Booth, in Hadfield, Essex, in 1890. 


\section{Robert Owen: Utopian home colonies}

Utopian socialist Robert Owen defended home colonies as the best vehicle for human happiness for the poor if they were properly planned and implemented. This fitted into his general philosophy that human misery and happiness depended very much on how society organized itself. In A New View of Society (1816), Owen states that three-quarters of the population of the British Islands (which included Ireland) are 'poor or working class' and 'unhappily situated'. This need not be the case because 'any general character ... may be given to any community [happy or miserable] ... by the application of proper means'. ${ }^{5}$ Moreover, for the poor to experience happiness, a particular form of collective or socialist life needs to be planned since 'individual happiness can be increased' in proportion only to an 'increase in happiness of all around him. ${ }^{6}$ At the heart of Owen's vision of colonies was the need to segregate the colony from the rest of society (in order to protect a collectivist economy) and engage the poor in cooperative farming.

In an essay entitled 'A Development of the Principles and Plans on which to Establish Self-Supporting Home Colonies ... .', published under the auspices of the British Home Colonization Society, Owen targeted the very poor of England. He begins his essay by describing the 'increase of poverty, destitution and crime' among the working classes in Britain and Ireland before arguing that the key was to engineer the right environment to create happiness rather than misery. 'Each of these individuals should be placed ... within those external arrangements that will ensure the most happiness. ${ }^{7}$ Happiness was thus the end and home colonies the means - properly planned and implemented. In the first substantive section entitled 'General Arrangements of the Proposed Home Colonies', Owen provides in written and pictorial form the specific layout of the colony. Life in the home colony would be dominated by agrarian labour: 'It is proposed ... that agriculture should form the basis of all. ${ }^{8}$

Thus, at the heart of the colony were four farms, using the typical idyllic and romantic language to describe the cultivation of 'empty' land in the countryside:

The Estate belonging to the Colony, laid out in Four Farms but having the appearance of a Park, with its hills and dales, its wood and water ... these farms will be cultivated, as far as population will admit, with the spade, and kept in the best order and the most productive state. About the centre of each farm will be the requisite Agricultural buildings. ${ }^{9}$ 
It is worth noting, because both William Allen and William Booth will make the same argument, that the simplest of tools - the spade - rather than ploughs or other kinds of sophisticated but less laborious tools should be used. The focus on simple technology such as the spade was common to English home colonialists and one finds it echoed in settler states like Canada, where the government also insisted indigenous peoples be limited to the simplest of tools. Both kinds of spade-based colonialism reflect a paternalistic approach to those deemed to be 'backward' and 'idle', a 'romantic' notion of being as close to the soil as possible and to the principle of industriousness by insisting upon the most laborious form of cultivation.

Owen argues for collective rather than private ownership of land:

It is proposed that each establishment of these Colonies shall, in the first instance, be the property of a joint-stock company; who ... shall let the whole, upon lease, to a company of tenants; the latter having power gradually to fine down the rents, and ultimately to become the owners. ${ }^{10}$

Owen concludes his essay by arguing that the difference between what exists currently for the poor, in the way of parish relief, poorhouses and pauper emigration, and his proposed utopian colonies is happiness. 'The difference between the two systems ... with respect to the formation of human character, and the enjoyment of superior happiness, there can be no comparison. ${ }^{11}$ Elsewhere, Owen also directly challenges those who argue pauper emigration is the answer in terms of both cost and outcomes. As president of the fourth congress of the 'Association of All Classes of All Nations', Owen states that if you compare the 'advantages of superior home colonies with the disadvantages of individual emigration into foreign climes you will, we are sure, find the difference far beyond your present means of estimation'. ${ }^{12}$

The 1841 essay in defence of home colonies provides detailed instructions as to the architecture of the colony, the buildings and spaces within it. Owen models his home colonies in Britain in part on Jan van den Bosch's labour colonies in Holland. Albert Schrauwers observes that van den Bosch's scheme:

bears striking similarities with [those of] Robert Owen, the English utopian socialist and correspondent of the Benevolent Society, who was proposing rural colonies for the poor in England at the same time. ... Both men saw individual character as the product of 
circumstances ... however, the malleability of character meant that it could be improved through education and better conditions. ${ }^{13}$

But while Owen and van den Bosch agreed on some aspects of domestic colonialism (segregation, agrarian labour and improvement), they differed on religion and the free market. Owen as a secular socialist viewed his 'home colonies' as secularist alternatives to the capitalist system (collectively owned and cultivated by the members of the colony itself), whereas van den Bosch viewed his labour colonies as products of his Protestant faith that supported existing labour markets. In his article, National Industry in General and the Netherlands (1819), van den Bosch concludes that his colonies will not 'distort markets in either labor or goods' but support them by turning individuals into productive labourers and return them to the labour market. ${ }^{14}$

Despite his lofty claims for the home colony to solve poverty in Britain, Owen's scheme failed due to a lack of support by British philanthropists. In response to his own question, 'why did ... Owenite institutions [home colonies] wither so quickly as compared with other philanthropic causes which crusaded successfully in the early nineteenth century [such as] Sunday schools, anti slavery and temperance?', Harrison argues Owen's reliance on happiness defended in humanitarian and secularist terms rather than religious redemption or salvation provides the answer:

Owen's philanthropy was predominantly secular. It was antagonistic towards the religion of evangelical Christianity and the faith of political economy. Consequently, it found no favour with the dominant schools of philanthropy ... Owenite philanthropy was ... rooted in the humanistic values of the Enlightenment. Utility or the pursuit of happiness was its starting point, not the saving grace of Christ Jesus ... the Owenites stood condemned as infidels and their philanthropy was therefore discountenanced. ${ }^{15}$

\section{Quaker William Allen and home colonies}

William Allen was a close ally of James Mill, and an associate of both Jeremy Bentham and Robert Owen. Indeed, it was Allen who 'induced Bentham to invest money in the New Lanark establishment. Owen, whose benevolent schemes had been hampered by his partners, bought them 
out, the new capital being partly provided by Allen, Bentham, and others'. ${ }^{16}$ Ultimately, Allen and Owen famously parted ways in 1828 as Owen resigned all connection to New Lanark. In the middle of this process of parting ways (in 1826), Allen wrote a treatise entitled Colonies at Home; or, The Means for Rendering the Industrious Labourer Independent of Parish Relief and for Providing the Poor Population of Ireland by the Cultivation of the Soil. This treatise, published 15 years before Robert Owen's own treatise on home colonies, also had a focus on the transformation of the 'idle' into the 'industrious' through the segregation of the poor into colonies, engagement in agrarian labour and proper planning.

Being a pauper and living in misery was constructed by society, according to Allen; if life for the poor were planned in a different way, their suffering could be alleviated. At the same time, revenues could be raised through the sale of agricultural produce. The first sentence thus reads:

On considering the circumstances of the poorest Classes of the population, during my travels in different Countries; I have been convinced that much of the misery which exists among the Poor, everywhere, might easily be obviated by a few judicious arrangements; and particularly, by settling them down upon small portions of Land and teaching them to cultivate that Land in the most profitable manner. ${ }^{17}$

Unlike Owen, Allen made the case for private allotments as opposed to collective ownership; but, like Owen, he was committed to 'spade' husbandry because it is more laborious, brings the idle poor closer to the land and creates more revenues to offset the cost of maintaining this population: 'It has been found, by actual experiment, that when pains are taken to dig land well with a spade more is produced' than with a plough or other means. Allen also argued that home colonization is better and less costly than emigration: 'Encouragement is given to emigration and this at considerable expense; while at the same time, the class of persons who are thus expatriated, is precisely that ... we should the least wish to part with.' ${ }^{18}$ Thus, the economic benefits of home colonies, whether through spade husbandry or in comparison to external colonization, are emphasized.

The text provided a very detailed plan as to how home colonization should occur, with the supply of manure addressed, followed by what crops ought to be grown using a year-by-year crop rotation diagram. He 
also provided a diagram for the cottages and how the rooms ought to be laid out in each and concluded the essay by making the case that home colonies, properly implemented in accordance with these detailed blueprints, would increase the happiness of the poor and society as a whole:

If those whom Divine Providence has intrusted with riches, would duly lay these things to heart, and avail themselves of the means put into their hands, they would in no very long time change the face of their Country. The moral of the great mass of the people would be improved, their happiness in consequence augmented, and the blessed effect of it would be felt through all the ramifications of Society. ${ }^{19}$

Thus, the happiness of the British poor requires the implementation of a proper and detailed plan within segregated colonies on uncultivated soil where members use spades and plant particular crops within a specific organizational layout.

In 1823, Allen implemented his domestic colonial arguments and set up an agricultural colony with small allotments in Lindfield, Sussex, following his blueprint to create a 'rural colony'. In 1827, Allen wrote to Prince Alexander Galitzin of Russia to tell him that Linfield was the model for his Colonies at Home essay and sent him a copy of the essay for Tsar Nicholas I:

If thou shouldest judge it suitable, please to present the enclosed to Emperor Nicholas, with my very sincere respects. It is what his beloved brother wished me to send to him, when I had finished it. The title is 'Colonies at Home' and it contains those plans for promoting the comfort and happiness of the agricultural poor, which I am now carrying out at Lindfield Sussex..$^{20}$

Allen also described a periodical he began at Lindfield as 'a repository for hints and suggestions calculated to promote the comfort and happiness of men'. ${ }^{21}$

One curious aspect of the Lindfield colony was that those living near it often referred to it as 'America', tying together in a very concrete and explicit way the settler colony of America with the home colony of Lindfield. In his 1884 biography of Allen, Fayle provides an account of a conversation he had with a young American he met on his way to 
Lindfield. When the American asked Fayle his destination, he answered 'America' and went on to explain:

[Lindfield] is the capital of America ... [William Allen was] the George Washington of these parts, from whence he used to go and see what we have seen and soothe his mind with the beauty of Nature; from whence, also he could look down on his flourishing 'Colony' ... this new America - a land of promise to some generations, in its small way, as your big continent is to thousands of thousands from the Old World at this day. ${ }^{22}$

Locke's famous words 'all the world was America' take on a new meaning here. The 'settler colony' of America and the home colony of Lindfield - according to the ideology of domestic colonialism - serve the same purpose: 'give the peasant a chance by working on his self-respect so as to render him independent of parish relief, by letting him have a little land upon fair terms and directing him in the cultivation of it'. ${ }^{23}$ Fayle concludes in the biography that 'the founder [William Allen] had clearly called a New World into existence' in Lindfield. ${ }^{24}$

Referring to Lindfield Colony as the 'New World' also speaks to the romantic language so often used by domestic colonialists of a promised land within which one could redeem oneself, and find happiness out of misery. Referring to Lindfield as America was not unique to Fayle or Allen. As Margaret Nicolle notes, 'the Lindfield experiment was like a small America to the people of the area', ${ }^{25}$ meaning a promised land of happiness and hope - a 'new world' in the midst of the old. Nicolle asks why a colony in Sussex might be called America to those living near it. Her answer is 'Colonies were seen as a way for the poor to have a fresh opportunity in life.'

Allen thought Lindfield could be a model not only for Russia, as mentioned above, but also for Ireland, which became particularly important to him during the Irish famine of the early 1820s:

By May [1822] reports of distress were already so alarming that a private relief committee was formed in London [of] Irish and English Quakers ... When the [British and Irish Ladies committee] appealed to the ubiquitous William Allen for ideas, his response was to recommend the Irish communal villages be set up based on his model English community of Lindfield. ${ }^{26}$ 
Allen's plans for exporting his colony to other places such as Ireland and Russia had poor results. Nicolle observes that the Emperor in Russia tried experiments with little success and Irish correspondents told Allen it would be problematic to implement. As Irish novelist Maria Edgeworth wrote in a letter to Allen about his plans for home colonies in Ireland in 1827:

In attempting to carry them into execution in this country, there would be found obstacles of which you can form no estimate ... Things impossible for you to foresee, perhaps impossible for your English imagination to conceive would happen ... you will be cruelly disappointed not in promise, but in performance. ${ }^{27}$

Thus, Allen was ultimately 'never able to raise the funds required' to create home colonies in Ireland. ${ }^{28}$

As for Lindfield itself, it too failed. As early as 1824, the pastor Sydney Smith wrote to Allen to express his grave doubts about the colony experiment: 'I often see the best intended Schemes of the assistance of the poor ending in disappointment ... Such schemes are often laid before the public in the first Honeymoon of the Experiment and nothing is told of their subsequent failure. ${ }^{29}$ The key failure for most critics of the period according to Nicolle was the cost of the colony; more recently, historians have argued the model was flawed. ${ }^{30}$ Thus, William Allen's own colony was a failure in practice in his lifetime.

\section{William Booth, the Salvation Army and farm colonies for the submerged tenth}

The most famous and influential domestic colonialist at the end of the nineteenth century in Britain was William Booth, founder of the Salvation Army. Booth published a book, In Darkest England and the Way Out (1890), that laid out an ambitious colony scheme for Britain and beyond. While today the Salvation Army is known for its urban-based centres that provide food and shelter to the poor and homeless, Booth's original plan saw these 'city colonies', as he called them, as mere conduits to the central feature of his plan: the domestic farm labour colony. Booth begins his book by making a direct parallel between darkest Africa and the 'submerged tenth' or idle poor of 'darkest England', focusing on the shared role that idleness plays in the darkness encountered by 'negroes' in the 'Equatorial forest' and the poor in the streets of 
London: 'Just as in Darkest Africa ... so with us, much of the misery of those whose lot we are considering arises from their own habits. ${ }^{31}$ But 'for Darkest England, as for Darkest Africa, there is a light beyond'. It is this 'light' that will provide 'a way out' - the promise in the title of his book. Using the romantic language so often associated with the home colony as the path to happiness Booth notes:

I think I see my way out, a way by which these wretched ones may escape from the gloom of their miserable existence into a higher and happier life ... Mr. Stanley never succumbed ... every step forward brought him nearer his destined goal, nearer to the light of the sun, the clear sky and the rolling uplands of the grazing land. ${ }^{32}$

Thus, for Booth, the external colony in Africa has its parallel in England - in both cases those who are 'backward' and 'idle', living in misery and wretched conditions can find their way out to lightness and happiness through colonization. The juxtaposition of the binaries of dark and light, misery and happiness, idleness or backwardness, and progress or improvement suffuses Booth's book. At the heart of this process towards a happier life is agrarian labour and the farm colony in the countryside outside the city. Booth's vision is a bucolic one - rolling hills upon which animals graze, wide open skies with fresh air and, above all, sunlight that conquers the dark.

Booth creates a tripartite colonial model: a) city colonies to gather the idle poor in urban centres who would be transported to: b) 'farm colonies' within England where they would be trained in agricultural skills and educated in order to improve their moral character: 'Here [in the farm colony], the process of reformation of character would be carried forward ... [and] including those forms of labour and that knowledge of agriculture'. ${ }^{33}$ Booth, like the other domestic colonialists described above, emphasizes the spade: 'On arrival at the Farm they would [be] at once told off to work ... in spade husbandry upon what is called the system of "intensive" agriculture' that will yield 'much greater results than when you merely scratch the surface with a plough'. ${ }^{34}$ 'Intensive' in this sentence clearly means ensuring the work is more laborious than with a plough or other implement less time-consuming and thus, for Booth, spade husbandry is defended in terms of the intensity of labour as well as the amounts of produce. After being properly trained at the domestic farm colony and transformed into agrarian labourers, members of the colony were sent to farms in England or transported to: c) overseas colonies. 
In essence, Booth combines a domestic colonialism marked by a Christian 'progressive' view of idleness as a failure in one's moral character with a 'benevolent' and 'liberal' view of improvement and creating 'happiness' for the poor themselves rather than simply punishing or constraining them. The overseas colony also introduces a form of settler colonialism through which the retrained and reformed English pauper could resettle in one of Britain's colonies and thus help that settler state to build its nation further, often on indigenous land. As Booth developed and implemented his scheme in the 1890s, he believed he could solve poverty worldwide. For Booth, colonization was primarily a social policy to solve domestic problems rather than an imperial policy (although it has settler colonial implications).

But Booth argues that within the British colonies there were still 'millions of acres of useful land to be obtained almost for the asking, capable of supporting our surplus population ... were it a thousand times greater', ${ }^{35}$ echoing John Locke's colonial references in the Two Treatises to land that could hold 'a hundred thousand times as many' if only labour were introduced to it. He also makes it clear, however, like the other domestic colonialists already discussed, that pauper emigration on its own is not the answer: "[Some say] emigration is the true specific. The waste lands of the world are crying aloud for the application of surplus labour' but Booth emphasizes that 'emigration is not the panacea', particularly if those sent to 'settle' overseas are not trained in agrarian labour. ${ }^{36}$ Ultimately, he suggests an overseas colony owned by the Salvation Army itself: 'we propose to secure a tract of land [overseas] ... prepare it for settlement ... settling it gradually with a prepared people [i.e. trained in agrarian labour] and so create a home for these destitute multitudes' (58). Again, key to the success of emigration is training in spade husbandry. He asks facetiously, 'Whom are you to emigrate? ... These lads who never handled a spade? ${ }^{37}$

Like Allen but unlike Owen, Booth argues that religious instruction as well as agricultural training is necessary since the latter transforms the idle person into an industrious one and the former transforms the corrupt mind and spirit into a moral one. Religious instruction increases the chance of happiness:

Habits of industry, sobriety and kindness with them would create a restfulness of spirit which goes far in the direction of happiness and if religion were added it would make the happiness complete ... They would be far better circumstanced for happiness in this life and in the life to come than in their present liberty. ${ }^{38}$ 
He concludes that once his plans are implemented in full, the whole of humanity will be lifted from misery into a happy place: 'When this scheme is perfected and fairly at work, every meeting and every procession will be looked upon as an advertisement of the earthly as well as the heavenly conditions of happiness. ${ }^{39}$

As with Owen and Allen, Booth is very specific about farm colonies and the detailed planning necessary to their success - the location of the farm colony, the proximity to a rail line, the configuration of the cottages, the kind of instruction in both religion and agriculture, and so on. In other words, happiness for the poor can be achieved once again only through elaborately planned city and farm colonies within which the life of its members is carefully regulated and planned. Even the question of marriage ought to be overseen and planned: 'while I have been busily occupied in working out my Scheme for ... labour ... why could not something like the same plan be adopted in relation to men who want wives and women who want husbands?' He goes on to suggest there could be an agency that could help to suggest whom to marry and a month of 'matrimonial training' for women to ensure life-long happiness: 'A month spent before marriage in a training home of housewifery would conduce much more to the happiness of married life than the honeymoon which immediately follows it. ${ }^{40}$ Thus, happiness requires planning in the private and the public lives of the poor with a gendered emphasis on wives learning the skills of 'housewifery'.

Booth's domestic colonial scheme was widely disseminated: 'Darkest England was a great popular success, selling roughly 115,000 copies within the first few months ... In addition, Booth received strong support in the British press ${ }^{41}$ and his ideas were promoted and implemented by supporters in England, Scotland, America and Canada. He was challenged by conservatives in Britain who saw his scheme as socialist: 'Booth lost credibility among conservatives when several of his strongest supporters - T. H. Huxley, Ben Tillet and the editors of Reynold's Newspaper - argued that his system of colonies ... promoted socialism in Britain. ${ }^{42}$ One of his greatest critics was Herbert Spencer, to whom Booth responded about the popularity of his ideas among liberals in 1894: 'I am not discouraged by anything Herbert Spencer may have said about such colonies ... there is not a liberal in the present [British] government who is not in hearty sympathy with me. ${ }^{43}$

Like Owen and Allen, Booth not only wrote about home colonies, but also tried to implement them. In 1891, he established a 3,200-acre farm labour colony at Hadleigh, Essex, along with five city colonies and 18 labour bureaux in London, all designed to feed people into the farm 
colony. ${ }^{44}$ In contrast to Owen's scheme, the Hadleigh colony sought to train farmers who would become private property owners. As Brown says of the Hadleigh colony: 'the aim was largely land reform ... providing work for the unemployed but also ... giving them the necessary training in agriculture to allow them to become small-holders' ${ }^{45}$ Both the ethics (does the colony improve people and make them happier?) and economics of colonization (do they raise revenues in the short run for the care of the poor and/or turn the idle into productive citizens in the longer term?) were at the forefront of any discussion in the media about Booth's scheme. Thus, the headline of an article in the Pall Mall Gazette, in 1892, reads, 'Will the General's Farm Colony "Pay"?'. ${ }^{46}$ As the author of this article argues, 'The two points everybody is interested in are-Are the colonists better men ... second, is the colony going to pay?' Or to put it another way - is domestic colonization going to work in the very terms that Booth justified them, namely in being less costly to society and creating better, more industrious and happier people?

With the appropriate planning and training in a home colony, Booth argues the idle poor could leave 'Darkest England' and create happiness rooted in labour in an overseas colony:

The essence of my colony is the transfer of prepared persons from the overcrowded slums. These persons are not submerged but are in such circumstances that their poverty may lead them to be submerged. Their habits may be changed so that they may help to form what I consider the glory of any country, an honest, hard-working peasantry, contented with plenty to eat, and have a happy, hallelujah time of it. ${ }^{47}$

In other words, the home colony will not only produce happiness within England but also, as these rehabilitated individuals are sent overseas, create happiness in settler colonies as well.

As with Owen and Allen, the promise, in theory, of a future full of happiness and hallelujahs was, in practice, the opposite. The only successful aspect of Booth's plans was the city colony that exists to this day. This was largely because his city colonies removed the unwanted beggar or pauper from the city street and so became enormously popular with power brokers and governments in the larger cities of England, and eventually the world, as an immediate stop-gap measure for the homeless poor. But the farm colony scheme was viewed as too socialist, too farfetched and/or too costly. Thus, the true heart of Booth's scheme - the 
farm colony - did not succeed, even though the first part of it was wildly successful. Moyles comments:

The financial response to Booth's Darkest England scheme had been so overwhelming that, in a very short time, Salvation Army Rescue Homes, Industrial Homes, and City Shelters were familiar features of most major cities throughout the British-speaking world. The second wing - the Farm Colony - had not met with the same success. ${ }^{48}$

To this day, we see the 'city colony' or Salvation Army shelters present in most cities throughout Britain and indeed the world.

\section{Conclusion}

All three of these domestic colonialists (Owen, Allen and Booth), it could be argued, had good intentions with respect to the poor of Britain as they sought to transform the lives of the idle poor from that of dependency and misery into self-sufficiency and happiness. And they all thought they had come up with the perfect solution to achieve this end in England, which could then be exported to the rest of the world - in the case of Owen to America, in the case of Allen to Ireland and Russia, and in the case of Booth to settler states within the British Empire. At the heart of their colonial schemes was the transformation of individual paupers, via segregation from society, education, training/engagement in agrarian labour and improvement of land in order to create ethical benefits (self-sufficiency/happiness) and economic benefits (revenues for the philanthropist or state and increased value of the land). Colonization, in other words, originally and primarily a policy to serve British foreign and imperial policy goals in the seventeenth, eighteenth and nineteenth centuries, was turned inwards by these thinkers and philanthropists (among others) in the middle of the nineteenth century in order to serve the domestic problem of the urban poor in England. And while the colony, according to its proponents, heralded in a brand new world where poverty would be eradicated for good and the existing poor would be made industrious and happy, the reality in practice was the opposite. Rather than being the answer to the various social problems besetting Britain in the nineteenth century, the home colony became an abject failure in practice - not getting off the ground at all, lasting less than a decade and/ or being rife with abuse and conflict. 
While some, including the domestic colonialists themselves, argue this was because the scheme they devised in such detail was not properly implemented as specified in their various blueprints or plans, the reasons for the rapid failure of such institutions was much deeper than implementation and can be found in the ideology of colonialism itself. Some explanations advanced at the time - Owen's colony was too socialist or not religious enough, Allen's colony was too costly, Booth's colonial scheme was too complex or socialist - provide us with some insights as to why societies or governments did not embrace colonies, but they do not explain why all of these different kinds of colonies failed and why so quickly. If we are to believe the argument that Owen's colony failed because it was too socialist/utilitarian and not religious enough, it cannot explain why Allen's or Booth's farm colonies failed: both explicitly embraced Christianity and, in Allen's case, he created individual allotments rather than collective ownership at Lindfield.

The rapid failure of all of these colonies lies neither in the incorrect implementation of the schemes (as their proponents argue) nor the limitations of socialism, Quakerism or liberal Protestantism (as others argue), but in the ideology of colonialism itself - namely, the central claim that it is possible to engineer the happiness of the poor through detailed plans based on the principles of segregation and engagement in agrarian labour and spade husbandry. For domestic colonialists, 'idleness' was, by definition, understood as something produced within an individual's character by his/her home environment. Change the environment, break habits, introduce labour and you transform idleness into industriousness and misery into happiness. The focus on changing individuals' character and behaviour, even if it is more humane than it is punitive, fails to address larger structures and processes - urbanization and industrialization - that were instrumental to the problems of unemployment and poverty on the city streets of Britain. While Allen believed individual idleness and moral character were the source of misery and Owen concurred but added the structures of marriage, religious belief and private property, neither analysed the larger economic and social structures of industrialized capitalist society in the way that Marx and his followers or reform liberals did from the middle of the nineteenth century onwards, which meant creating societal/state structures to support the poor. Domestic colonialism failed therefore because its focus was entirely on changing individuals from within rather than addressing societal structures.

Beyond the failure to deal with the larger structural forces that gave rise to the urban poor, home colonialism was also flawed in how it constructed the solution to poverty. First, the idea that a very detailed plan 
must be implemented in the exact manner specified by the domestic colonialist on behalf of all people who are poor ignores both human diversity and agency. Such detailed blueprints failed to acknowledge the democratic impulse within any community to have their own blueprints, while the diversity of individual ideas and actions are stifled by a one-size-fitsall top-down solution. Second, while the countryside location may be a healthier place for people to live rather than industrialized and crowded city streets, there is no inherent magical character to such locations as these colonialist thinkers assume - indeed it might increase a person's sense of isolation, marginalization and unhappiness as they are removed from those organic links to family and friends. More often than not, the countryside as redemptive is taken as an article of faith by British home colonialists, but this commitment reveals more about their own romantic proclivities than anything else. If, rather than removing people from the city, the focus was on how to make the city a better place in which to live, particularly for the very poor and unemployed, their unhappiness, living their lives as part of a community, might be better addressed.

Third, the colonial principle of improvement is deeply problematic in and of itself because it requires philanthropists and superintendents to exercise power by seeking to change the poor from within. Defenders of the colony model thus believed individual happiness depended upon educating the poor to recognize faults in their own minds, bodies and habits in order to become something different. This core belief in an internal form of change provides fertile ground for the violation of mental or physical boundaries as the superintendent or staff of the colony seek to improve the individual. The principle of 'segregation' and the marginalized nature of those living within the colony compound the problem of abuse as these segregated institutions were built beyond the oversight of society. Consequently, those who wanted to abuse their charges could do so with a sense of impunity. The colony then becomes a place within which the individual's mind and body could be easily violated in the name of improvement, redemption or salvation in relative obscurity.

Thus, I hope to have shown how colonialism had a domestic face in Britain as well as a foreign and imperial face overseas; those who supported home colonies (unlike external colonies or empires) were often progressives (reform liberals and socialists) who believed their solution to poverty and pauperism was a more humane and less costly option that would improve rather than punish or constrain the poor and provide the basis for happiness. In seeking a solution via segregation and agrarian labour in the countryside to redeem souls and create productive and happy citizens using a highly elevated and romantic language, domestic 
colonialists created not only false hope but also the conditions under which these same populations were isolated and often abused in the service of improvement. It is not surprising, therefore, that these home colonies failed quickly and spectacularly as the ideology producing them was inherently flawed - despite the good intentions of those defending them. Perhaps the rise and fall of the domestic colony as a model for happiness is best summed up in the pithy description that Jeremy Bentham once used to describe the ideas of Robert Owen more generally: they 'begin in vapour and end in smoke'.

\section{Notes}

1. Barbara Arneil, Domestic Colonies: An Inward Turn to Colony (Oxford: Oxford University Press, 2017).

2. W. E. Fernald, 'The History of the Treatment of the Feeble Minded', Proceedings of the National Conference of Charities and Correction, 20th Annual Session, 8-11 June 1893, Chicago (Boston: Press of Geo. H. Ellis), 203-21; W. E. Fernald, 'The Burden of Feeble-Mindedness', Journal of Psycho-Aesthenics (March 1912): 87-111. http://www.disabilitymuseum.org/dhm/lib/detail.html?id=1208\&page $=$ all, 1-10 (accessed 2 March 2019); C. Bernstein, 'Colony and Extra-Institutional Care for the Feeble-Minded', Mental Hygiene 4/1 (1920): 1-28; C. Bernstein, 'Colony Care Isolation of Defective and Dependent Cases', American Association of Mental Deficiency Proceedings 26 (1921): 43-59.

3. W. Booth, In Darkest England and the Way Out, 1st edn (Gutenburg Project, 1890); J. Brown, 'Charles Booth and Labour Colonies, 1889-1905', The Economic History Review 21/2 (1968): 349-60; France Gouda, Poverty and Political Culture: The Rhetoric of Social Welfare in the Netherlands and France, 1815-1854 (New York: Rowman and Littlefield, 1995).

4. Barbara Arneil, John Locke and America: A Defense of English Colonialism (Oxford: Oxford University Press, 1996).

5. Robert Owen, A New View of Society, or, Essays on the Formation of Human Character and the Application of the Principle to Practise (London: 1816), 107.

6. Owen, A New View, 110.

7. Robert Owen, A Development of the Principles and Plans on which to Establish Self-Supporting Home Colonies: As a Most Secure and Profitable Investment for Capital, and an Effectual Means Permanently to Remove the Causes of Ignorance, Poverty, and Crime (London: Home Colonization Society, 1841), vii.

8. Owen, A Development of the Principles, 67.

9. Owen, A Development of the Principles, 40.

10. Owen, A Development of the Principles, 37; emphasis added.

11. Owen, A Development of the Principles, 79.

12. Robert Owen, 'Address to the Congress of the Association of All Classes of All Nations', in Owenite Socialism: Pamphlets and Correspondence, 1839-1840, ed. Gregory Claeys (London: Routledge, 2005), Vol. 6, 136.

13. Albert Schrauwers, "The "Benevolent" Colonies of Johannes van den Bosch: Continuities in the Administration of Poverty in the Netherlands and Indonesia', Comparative Studies in Society and History 43/2 (2001): 310.

14. Schrauwers, 'The "Benevolent" Colonies', 304.

15. John F. C. Harrison, Robert Owen and the Owenites in Britain and America: The Quest for the New Moral World (London: Routledge, 2009), 33; emphasis added.

16. Leslie Stephen, The English Utilitarians, vol. 1: Jeremy Bentham (London: Duckworth, 1900), 218.

17. William Allen, Colonies at Home; or, the Means for Rendering the Industrious Labourer Independent of Parish Relief, new edn (Lindfield, Sussex, 1832), 10. 
18. Allen, Colonies at Home, 11.

19. Allen, Colonies at Home, 27.

20. William Allen, Life of William Allen with Selections from Correspondence, Vol. 2, ed. Charles Gilpin (London: Arthur Wallace, 1847), 435.

21. Allen, Life of William Allen, 442.

22. Joshua Fayle, The Spitalfields Genius: The Story of William Allen (London: Hodder and Stoughton, 1884), 7.

23. Fayle, The Spitalfields Genius, 10.

24. Fayle, The Spitalfields Genius, 15.

25. Margaret Nicolle, William Allen, Quaker Friend of Lindfield 1770-1843 (Lindfield Parish Council, 2001), 126.

26. Elizabeth Hatton, The Largest Amount of Good: Quaker Relief in Ireland, 1654-1921 (Kingston: McGill Queen's University Press, 1993), 59.

27. Cited in Allen, Life of William Allen, 133-4.

28. Hatton, The Largest Amount of Good, 75.

29. Allen, Life of William Allen, 135.

30. Allen, Life of William Allen, 143.

31. Booth, In Darkest England, 10, 11.

32. Booth, In Darkest England, 12; emphasis added.

33. Booth, In Darkest England, 58.

34. Booth, In Darkest England, 81.

35. Booth, In Darkest England, 58.

36. Booth, In Darkest England, 49.

37. Booth, In Darkest England, 50.

38. Booth, In Darkest England, 128.

39. Booth, In Darkest England, 148.

40. Booth, In Darkest England, 143.

41. H. R. Haggard, The Persistence of Victorian Liberalism: The Politics of Social Reform in Britain 1870-1900 (Westport: Greenwood Press, 2001), 73.

42. Haggard, The Persistence of Victorian Liberalism, 73.

43. W. Booth, 'In 70 New World Cities' (26 October 1894), The Windsor Evening Record (Windsor, Ontario, Canada).

44. Haggard, The Persistence of Victorian Liberalism, 72.

45. Brown, 'Charles Booth and Labour Colonies', 357.

46. 'Will the General's Farm Colony “Pay”?' (15 September 1892), The Pall Mall Gazette, London.

47. Booth, cited in R. G. Moyles, William Booth in Canada: Descriptions of His Six Visits 1886-1907 (Edmonton: AGM Publications, 2006), 45.

48. Moyles, William Booth in Canada, 21.

\section{Bibliography}

Allen, William. Colonies at Home; or, the Means for Rendering the Industrious Labourer independent of Parish Relief (new edn). Lindfield, Sussex, 1832.

Allen, William. Life of William Allen with Selections from Correspondence, Vol. 2. Edited by Charles Gilpin. London: Arthur Wallace, 1847.

Arneil, Barbara. 'Disability and Self Image in Modern Political Theory', Political Theory 37/2 (2009): 218-42.

Arneil, Barbara. Domestic Colonies: An Inward Turn to Colony. Oxford: Oxford University Press, 2017.

Arneil, Barbara. John Locke and America: A Defense of English Colonialism. Oxford University Press, 1996.

Bernstein, C. 'Colony and Extra-Institutional Care for the Feeble-Minded', Mental Hygiene 4/1 (1920): 1-28.

Bernstein, C. 'Colony Care Isolation of Defective and Dependent Cases', American Association of Mental Deficiency Proceedings 26 (1921): 43-59.

Booth, W. In Darkest England and the Way Out, 1st edn. Gutenburg Project, 1890. 
Booth, W. 'In 70 New World Cities'. The Windsor Evening Record (26 October 1894). Windsor, Ontario, Canada.

Brown, J. 'Charles Booth and Labour Colonies, 1889-1905', The Economic History Review 21/2 (1968): 349-60.

Fayle, Joshua. The Spitalfields Genius: The Story of William Allen. London: Hodder and Stoughton, 1884.

Fernald, W. E. 'The Burden of Feeble-Mindedness', Journal of Psycho-Aesthenics (March 1912): 87-111. http://www.disabilitymuseum.org/dhm/lib/detail.html?id=1208\&page=all, 1-10 (accessed 2 March 2019).

Fernald, W. E., 'The History of the Treatment of the Feeble Minded', Proceedings of the National Conference of Charities and Correction, 20th Annual Session, 8-11 June 1893, Chicago. Boston: Press of Geo. H. Ellis), 203-21.

Gouda, France. Poverty and Political Culture: The Rhetoric of Social Welfare in the Netherlands and France, 1815-1854. Lanham, MD: Rowman and Littlefield, 1995.

Haggard, H. R, The Persistence of Victorian Liberalism: The Politics of Social Reform in Britain 1870 1900. Westport: Greenwood Press, 2001.

Harrison, John F C.. Robert Owen and the Owenites in Britain and America: The Quest for the New Moral World. London: Routledge, 2009.

Hatton, Elizabeth. The Largest Amount of Good: Quaker Relief in Ireland, 1654-1921. Kingston: McGill Queen's University Press, 1993.

Locke, John. Two Treatises on Government. Edited by Peter Laslett. Cambridge: Cambridge University Press, 1988.

Moyles, R.G. William Booth in Canada: Descriptions of His Six Visits 1886-1907. Edmonton: AGM Publications, 2006.

Nicolle, Margaret. William Allen, Quaker Friend of Lindfield 1770-1843. Lindfield Parish Council, 2001.

Owen, Robert. 'Address to the Congress of the Association of All Classes of All Nations'. In Owenite Socialism: Pamphlets and Correspondence, 1839-1840, edited by Gregory Claeys, Vol. 6. London: Routledge, 2005.

Owen, Robert, A Development of the Principles and Plans on which to Establish Self-Supporting Home Colonies: As a Most Secure and Profitable Investment for Capital, and an Effectual Means Permanently to Remove the Causes of Ignorance, Poverty, and Crime. Home Colonization Society, 1841.

Owen, Robert. A New View of Society, or, Essays on the Formation of Human Character and the Application of the Principle to Practise, London: 1816. http://www.open.edu/openlearn/ocw/pluginfile.php/607280/mod_resource/content/2/a207_12_essay1.pdf (accessed 2 March 2019).

Schrauwers, Albert. "The "Benevolent" colonies of Johannes van den Bosch: Continuities in the Administration of Poverty in the Netherlands and Indonesia', Comparative Studies in Society and History 43/2 (2001): 298-328.

'Will the General's Farm Colony “Pay”?' (15 September 1892). The Pall Mall Gazette, London. 


\section{5}

\section{Making Better Sense of Ideal Utilitarianism}

David Weinstein

\section{Introduction}

In the 'Preface' to his 2013 Mill, Frederick Rosen writes, 'I have tried to release Mill from numerous stale arguments and debates in an attempt to establish a more rounded view of his ideas as well as to capture the turmoil that surrounded his intellectual life.' ${ }^{1}$ Modern commentators have wrongheadedly manipulated and recast Mill 'to go to the heart of key issues in recent moral and political philosophy from a Millian perspective' at the cost of too often missing 'the heart of Mill's thought'. ${ }^{2}$ They typically reconstruct Mill via the lens of our own analytical preoccupations and conceptual conundrums rather than keeping to Mill's historical context of philosophical concerns. Instead of interpreting Mill, they appropriate him. And while appropriating Mill, or any historical philosophical figure for that matter, is often an excellent technique for thinking through our highly refined and technical disputes about the dimensions of consequentialism, theories of well-being and the like, it makes for poor intellectual history. We end up both recreating a Mill he would not recognize as well as fabricating a false chapter in the history of classical utilitarianism. We should do our best to avoid such bad habits in reading Mill because they corrupt whatever sense we try to make of his legacy as it was taken up by Sidgwick and his successors and critics from Moore through to the Oxford intuitionists and beyond.

While I am not sure that Rosen would put what is at stake in properly interpreting Mill as I have just put it, I do think that he would not object terribly to my spin on his intentions. As some readers may know, I have been riding the same hermeneutic hobby-horse that I have just 
attributed to Rosen for quite some time. In my view, to appropriate past philosophical texts is simply doing English-speaking, analytical moral and political theory by other means, which risks, among other things, displacing, marginalizing and condensing much that came just before it.

In what follows, I would like to examine G. E. Moore and Hastings Rashdall's versions of ideal utilitarianism through their respective responses to T. H. Green's idealism and Henry Sidgwick's classical utilitarianism. ${ }^{3}$ I will not claim that ideal utilitarianism should be understood as primarily a reaction to Green and Sidgwick, but I will insist that Moore and Rashdall cannot be interpreted properly unless we take more seriously their criticisms and appropriation of Green and Sidgwick. Green and Sidgwick were on their minds as much as any predecessors were when Moore published Principia Ethica in 1903 and Rashdall published The Theory of Good and Evil in 1907. Green and Sidgwick dominated Moore and Rashdall's intellectual context. They were shadows under which both laboured to at least soften or at best completely escape. Others, such as J. S. Mill, Herbert Spencer, F. H. Bradley and J. S. Mackenzie, figured prominently as points of departure as well as in Moore and Rashdall's ideal utilitarianism. I will not eschew taking up Mill, Spencer, Bradley and Mackenzie, though I will do so more in passing.

\section{Moore's 'hide-bound orthodoxy'}

W. J. Mander has recently insisted that analytic 'philosophy did not just magically replace the earlier Idealism, but rather developed alongside and in conscious opposition to it, and in this process Idealism shaped its successor; as truly as any parent shapes the child who rebels against it'. ${ }^{4}$ Bertrand Russell and G. E. Moore thus committed hermeneutical patricide in reconstructing idealism simplistically in order to overdramatize their own novelty. But Moore, for his part, oversimplified in my view not just idealists but other immediate predecessors such as Herbert Spencer, J. S. Mill and Henry Sidgwick. For Moore, Spencer, Mill and Sidgwick exemplified the errors of modern 'naturalistic' ethics while idealists, particularly T. H. Green, epitomized 'metaphysical' ethics at its worst.

Jennifer Welchman has similarly argued that Moore's purported revolution in ethics was less abrupt and decisive than we now believe, not least because Moore's contemporary readers, including his idealist critics, took issue with him in a much different way from that which we are now inclined to assume. ${ }^{5}$ Indeed, Bernard Bosanquet, for instance, 
thought Principia Ethica neither especially original nor revolutionary, though he conceded that Moore was a gifted critic. But so far as he could determine, Moore 'hampered himself with ideas no less dogmatic than those of the most hide-bound orthodoxy: and he is not yet therefore a critic in the true sense, a critic who can take the standpoint of that which he criticizes' (my italics). ${ }^{6}$ In other words, Moore inaugurated nothing particularly new. He was not so much innovative as he was a provocative but nonetheless sloppy reader of those he appropriated to illustrate alternative versions of the naturalistic fallacy as a preliminary move to constructing his ideal utilitarian alternative. And if no historical predecessors actually committed anything resembling the naturalistic fallacy, then the fallacy was a historical straw man, making Moore's rejection of naturalistic and metaphysical ethics much less of a philosophical new beginning and more of an ongoing colloquy of shared suppositions and overlapping, substantive normative claims. ${ }^{7}$

\section{Moore's rejection of classical utilitarianism}

Now, Moore seems to have been far more preoccupied with exposing how Spencer, Mill and Sidgwick went astray in committing the naturalistic fallacy than he was with showing up idealists such as Green. He devotes an entire chapter to condemning naturalistic ethics, which he regarded Spencer as exemplifying especially strikingly. ${ }^{8}$ Next follows a chapter disparaging Mill and then Sidgwick, though he regards Sidgwick far more favourably and for that reason I shall say something about his differences with Sidgwick here. Moreover, Moore's assessment of Sidgwick should assist us in making sense of Moore's dismissal of Green, too, because Sidgwick's rivalry with Green is significantly revealing about both.

Moore, like Sidgwick, was a utilitarian, though Sidgwick was a hedonist and Moore was not. Furthermore, both were non-naturalists and both deemed good unanalysable - or at least, Moore was convinced that Sidgwick deemed good unanalysable. Of all the hedonists:

Prof. Sidgwick alone has clearly recognized that by 'good' we do mean something unanalysable, and has alone been led thereby to emphasise the fact that, if Hedonism be true, its claims to be so must be rested solely on its self-evidence - that we must maintain 'Pleasure is the sole good' to be a mere intuition. ${ }^{10}$ 
Moore, then, praised Sidgwick's commitment to intuitionism and seemed to think that his methodological commitment to intuitionism somehow also committed him to accepting that good was necessarily unanalysable or undefinable. But it is unclear if Sidgwick thought good unanalysable or, if he did, whether he regarded this fact as especially significant. Nor is it plain that Sidgwick was particularly preoccupied with good anyway. Rather, as others such as David Phillips have claimed, Sidgwick viewed ethics as being fundamentally about what we ought to do and not about goodness. As Sidgwick stipulates at the very outset of The Methods of Ethics, "a "Method of Ethics" is explained to mean any rational procedure by which we determine what individual human beings "ought" - or what it is "right" for them - to do, or to seek to realise by voluntary action'. ${ }^{11}$

Now, notwithstanding Moore's preference for Sidgwick over Mill and his contention that Sidgwick was no less consumed with the problem of good than he was, Moore deemed Sidgwick's intuitionism a failure when all was said and done. And his account of its failure bears directly on his explanation of how metaphysical ethics purportedly fails as well as on his interpretation of the relationship between pleasure and good in metaphysical ethics. For Moore, Sidgwick's intuitionism goes wrong insofar as he holds intuitively that pleasure alone is good in itself. That is, Sidgwick errs in not appreciating that whatever goodness is, it is necessarily 'something beyond the limits of human existence'. Furthermore, whatever this something is, we typically experience it as pleasurable, making our consciousness of pleasure, and not pleasure itself, so significant. ${ }^{12}$ Our consciousness of pleasure is not identical with, but instead attends to, good. Our consciousness of pleasure merely marks goodness; therefore, the 'most that can be said for it is that it does not seriously mislead in its practical conclusions, on the ground that, as an empirical fact, the method of acting which brings the most good on the whole does also bring the most pleasure'. ${ }^{13}$ Hence, it is unsurprising that hedonists typically 'recommend a course of conduct which is very similar to that which I should recommend'. ${ }^{14}$ Nonetheless, 'in so far as their reason for holding these conclusions to be true is that "Pleasure alone is good as an end," they are absolutely wrong: and it is with reasons that we are chiefly concerned in any scientific Ethics'. ${ }^{15}$

At best, then, the most we could say in defence of hedonism, especially its utilitarian variety, is that maximizing pleasure 'was a matter of fact under actual conditions, generally accompanied by the greatest quantity of other goods', which would be a 'strange coincidence'. Assuming this unexpected coincidence true, pleasure would thus serve a 'good criterion' of right action. ${ }^{16}$ But, as far as Moore is concerned, there is little reason to suppose this coincidence. ${ }^{17}$ 


\section{Metaphysical ethics}

Moore begins Chapter IV, 'Metaphysical Ethics', referring to unnamed Hegelian-influenced 'modern writers' who also followed the Stoics, Spinoza and Kant in deploying metaphysical propositions as the grounds for inferring ethical propositions. The only 'modern' metaphysical writers he eventually comes around to naming and discussing specifically are J. S. Mackenzie and Green. ${ }^{18}$ According to Moore, Mackenzie typifies those modern metaphysicians who hold that our supreme good is realizing our true selves. More importantly and erroneously:

They also imply, as I said, that this ethical proposition follows from some proposition which is metaphysical: that the question 'What is real?' has some logical bearing upon the question 'What is good?' ... To hold that from any proposition asserting 'Reality is of this nature' we can infer, or obtain confirmation for, any proposition asserting 'This is good in itself' is to commit the naturalistic fallacy ... . It rests upon the failure to perceive that any truth which asserts 'This is good in itself' is quite unique in kind - that it cannot be reduced to any assertion about reality, and therefore must remain unaffected by any conclusions we may reach about the nature of reality ... . If, for instance, we are told that the ideal consists in the realization of the 'true self,' the very words suggest that the act that the self in question is true is supposed to have some bearing on the fact that it is good. ${ }^{19}$

Much of the remainder of Chapter IV is devoted to disparaging Kant. But near the end of the chapter, Moore returns to criticizing metaphysical writers after Kant, who though 'profess[ing] to base their Ethics on an investigation of will' fail to prove that what is willed in a certain way is also good. These writers 'make no attempt to shew that will is a criterion of goodness; and no stronger evidence could be given that they do not recognize that this, at most, is all it can be'. ${ }^{20}$ And even if we could show that willing in a certain way and goodness generally accompanied one another, it would remain 'doubtful whether the inference from "generally" to "always" would be valid, and almost certain that this principle would be useless'. ${ }^{21}$

Green, however, is the sole example Moore gives of a post-Kantian metaphysician who allegedly confuses willing in a certain way with goodness, which explains most probably why Mander thinks that Moore saw himself as 'offering a replacement' for Green's Prolegomena to Ethics, 
which, he adds, 'would certainly not have been lost on Moore's first readers'. ${ }^{22}$ Evidence for Green's confusing willing in a certain way with goodness is found where we see him 'explicitly stating that "the common characteristic of the good is that it [my italics] satisfies some desire"'. Furthermore, Green's 'conclusion may be ethical and may even be right, but he has not given us a single reason for believing them'. But the 'thing which a scientific Ethics is required to shew, namely that certain things are really good, he has assumed to begin with, in assuming that things which are willed in a certain way are always good' (my italics). Hence, the 'Prolegomena to Ethics is quite as far as Mr Spencer's Data of Ethics, from making the smallest contribution to the solution of ethical problems'. ${ }^{23}$

Notice that Moore is not saying that Green confuses goodness with what (say, willing in a certain way) just happens to satisfy our desires, but that he confuses goodness with desire satisfaction itself. Good is that constituted by desires being satisfied. Desire satisfaction is the whole of goodness. Whenever and wherever goodness is going on, desires are, analytically speaking, being satisfied. Goodness is not an object but an experience. But how desire satisfaction and willing in a certain way are related is unclear. Surely they are not identical experiences nor synonyms for the very same experience. In any case, notwithstanding whether the experience of satisfying desires is willing in a certain way, Green, as I have argued elsewhere, does indeed maintain, at least on numerous occasions, that happiness generally, if not always, accompanies good willing. But insofar as Green is claiming this, he is not analysing or defining good in Moore's sense. Green is not confusing a non-natural property, namely goodness, with another natural property, namely desire satisfaction. Therefore, he is not a relevant example of Moore's naturalistic fallacy. But he could be said to exemplify a complementary analytical error or fallacy of reasoning. He could seem to be guilty of confusing often enough the experience of happiness with the experience of willing in a certain way. He might be charged with claiming that happiness always, as an empirical fact, accompanies good willing. But, as I have just suggested, I do not think he ever makes such a claim; rather, he merely insists that happiness normally tends to accompany good willing.

While Mander, rightly in my judgement, faults Russell and Moore for committing hermeneutical patricide by reconstructing idealists simplistically and exaggerating the differences between them, he does much the same in misrepresenting idealism's rejection of classical utilitarianism. Classical utilitarianism wrought idealism no less than analytical philosophy was fashioned by idealism. Moore's contrasting assessment of hedonism (Chapter II) and metaphysical ethics (Chapter III) in 
Principia Ethica demonstrates this plainly, even though his account of Mill and Sidgwick on the one hand and his account of Mackenzie and Green on the other hand have much to be desired. Notwithstanding whether all four were more preoccupied with good or with ought, and notwithstanding whether they were what we now call consequentialists, all four tended to converge in recommending the same practical conduct. Though they may have given sufficiently distinct foundational reasons for the conduct they recommended, insofar as they understood good differently, happiness was hardly less crucial for idealists as it was for classical utilitarians. Indeed, they all held either that promoting happiness meant promoting goodness or that happiness in some sense typically accompanies promoting goodness and was therefore an extremely useful substitute 'criterion' for guiding our normative practical decisions. In finding what seemed to Moore to be the naturalistic fallacy in classical utilitarians and idealists alike, his Principia Ethica reminds us of just how much they constitute a historical continuum rather than the second being a dramatic break with the first.

\section{Hurka's 'school'}

Hastings Rashdall dedicated his 1907 The Theory of Good and Evil 'To the Memory of My Teachers Thomas Hill Green and Henry Sidgwick', though he adds in the 'Preface' that neither of these:

great writers to whom I feel I owe most in the special department of Ethics - the late Professor Sidgwick, and the late Professor T. H. Green whose lectures and private classes I used to attend as an undergraduate - can well be regarded as having said the last word upon the subject by students of a generation later who have profited not merely by the criticism which each of them supplies upon the other, but by the general progress of Philosophy since the first appearance of Sidgwick's Methods of Ethics (1874) and of Green's Prolegomena to Ethics (1883). ${ }^{24}$

But why should we care who influenced Rashdall unless we first have reason to care about Rashdall, whose reputation has faded?

Thomas Hurka's recent British Ethical Theorists from Sidgwick to Ewing as well as his 2011 collection, Underivative Duty, make a compelling case for once again taking up Rashdall. Hurka considers Rashdall a key figure in an underappreciated 'school' of British moral philosophers 
prominent from the 1870s to 1950s, which included not only more wellknown names such as Henry Sidgwick, G. E. Moore and W. D. Ross, but also J. M. E. McTaggart, H. A. Prichard, E. F. Carritt, C. D. Broad and A. C. Ewing. ${ }^{25}$ According to Hurka, this Sidgwick-to-Ewing school combined meta-ethical non-naturalism with normative realism. That is, they insisted that ethics was autonomous and underivative whether from evolutionary biology, psychology or metaphysics and that normative judgements were universal and objective, as well as simply sui generis. ${ }^{26}$

\section{Rashdall 'in the middle'}

Of course, insisting that despite their achievements, neither Green nor Sidgwick should be viewed as having said the 'last word' on ethics suggests that Rashdall did not view each uncritically. Indeed, insofar as he tried to combine them, we should expect that he rejected elements of their respective moral theories. But what Rashdall rejected from Green himself rather than his followers, such as Mackenzie, is not easy to determine because, not unlike Moore, Rashdall frequently takes Mackenzie as better exemplifying and saying more lucidly what Green was trying to say. ${ }^{27}$ This naturally raises the question of whether anything Rashdall says for or against Green is truly an interpretation of him.

However much Rashdall conflates Green with Mackenzie, he says many of their criticisms of classical utilitarianism are uncompelling. For instance, Rashdall rejected Mackenzie's claim (which he also says at one point Green purportedly agreed with and at another point disagreed with) that pleasures cannot be summed and therefore a sum of pleasures cannot be a possible object of desire. ${ }^{28}$ Rashdall also repudiates Mackenzie's allegation that pleasures were incommensurable, therefore making it impossible to determine whether any option before us was cardinally superior to any other. According to Mackenzie on Rashdall's account, because 'numerical values cannot, with any meaning, be assigned to two pleasures or sums of pleasure ... there can never be any meaning in the assertion "this pleasure is twice as great as that". ${ }^{29}$ Although Rashdall conceded that it is certainly difficult if not impossible to compare and rank pleasures cardinally, comparing and ranking them ordinally is hardly so demanding. We do it all the time. As Rashdall says, repeating McTaggart, "I feel no hesitation in affirming that the pleasure I get from a plate of turtle-soup is more than twice the pleasure I get from a plate of pea-soup.' Like comparing the size of flocks of sheep, comparing pleasures is 'none the less not quantitative because it is vague'. ${ }^{30}$ 
As for Green's further claim that maximizing pleasure was incoherent because maximum pleasure cannot be enjoyed all at once and because it is always possible to desire more, Rashdall responds much as Sidgwick did in criticizing Green on this same account. ${ }^{31}$ Rashdall remarks, 'To aim at a greatest possible sum of pleasures means to endeavor that as much pleasure should be got into a given time as possible and that the time which we are enjoying pleasure should be as long as possible. ${ }^{32}$ And see where Rashdall says:

The possibility of desiring a sum of pleasures was denied by the late Prof. T. H. Green but it is difficult to see on what grounds except the obvious but irrelevant fact that pleasures cannot be enjoyed as a sum. Such arguments are surely based upon a mere verbal quibble. You might as well deny that I can desire music because I cannot take in a whole symphony simultaneously, while each separate note, taken by itself, would not be music at all. When I say that I desire a sum of pleasures, I mean of course that I desire to get as much pleasure as possible, i.e. to enjoy pleasure as intense and as long lasting as possible. ${ }^{33}$

Furthermore, Rashdall faults Green implicitly in the guise of criticizing Mackenzie explicitly for thinking moral self-realization is an any less problematic object of desire and duty. If "the "self-realization" which Prof. Mackenzie wants is not in time at all, how can it be an object of human effort?' He adds, if 'it is in time, would he not think a longer duration of it better than a shorter? ${ }^{34}$

Moore is responsible for inventing non-hedonistic, ideal utilitarianism more than any other philosopher. But Rashdall gave it its name and disseminated it and defended it more systematically. Moore then, no less than Green and Sidgwick, also motivated Rashdall's moral thinking. The Theory of Good and Evil engages mostly the very same nineteenth-century philosophers as Moore does in Principia Ethica, namely Mill, Sidgwick, Spencer and idealists such as Green and Mackenzie. And in Is Conscience an Emotion? from 1914, Rashdall pays his debts to Moore, insisting that no one has rightly 'done so much to emphasise the ultimate, unanalysable, sui generis character of value-judgement as Mr. G. E. Moore, of Trinity College, Cambridge'. In asserting that pleasure is good, you necessarily mean 'something more' than that pleasure is pleasure and that whatever that something is, it 'is not expressible in any language that does not contain the word "good" or some synonym of it'. Moore was absolutely correct, insisting that good is simply 'indefinable'. ${ }^{35}$ And following 
Moore, he rejects hedonism, maintaining that he does 'not think that the pleasure-pain side of conscious experience is the only element which we take into consideration in pronouncing on its value'. Clearly, 'it is certainly one of the elements on which its value depends, and in the case of such elementary rules as we are considering, it is the only one that need be taken account of' (my italics). ${ }^{36}$ Though Rashdall does not elaborate here, I take it that in conceding that when considering elementary moral rules, it is enough simply to keep in mind the pleasurable consequences of our actions. This concession is not without considerable practical significance in establishing our fundamental moral obligations, in as much as it seems that Rashdall is conceding, not unlike Green, that classical utilitarianism can stand in most of the time as a proxy for determining right from wrong.

Rashdall's differences with Moore were subtle but not unimportant. Some of them reveal just how much Rashdall owed to Sidgwick in trying to build on and go beyond Mill. In Chapter III of Volume I of The Theory of Good and Evil, devoted to Sidgwick and entitled 'Rationalistic Utilitarianism', Rashdall says that Sidgwick's role in the 'development of English Utilitarianism may be indicated by saying that he takes up the controversy at the point at which it had been left by Mill'. Sidgwick's improvement of Mill was pivotal in the 'dialectic which leads away from Utilitarianism towards what I may be excused for calling by anticipation a higher and deeper Moral Philosophy' (ostensibly Rashdall's). ${ }^{37}$ Presumably, Moore's ideal utilitarianism constituted for Rashdall the next step in this dialectic coming between Sidgwick's hedonistic distillation of Mill and his own final, idealistic improvement. In other words, Sidgwick improved Mill by exposing how Mill was not consistently hedonistic in distinguishing between higher and lower pleasures. Moore then improved Sidgwick by proving why hedonistic utilitarianism was in any case flawed analytically. Rashdall then built on Moore's anti-hedonism by borrowing from Green among others.

For Rashdall, Sidgwick's greatest innovation over Mill was his recognition of the justificatory value of moral common sense. According to Rashdall, ideal utilitarianism suitably improved best comports with common-sense morality, revealing specifically Sidgwick's powerful methodological influence on him. Though Rashdall held contrary to Sidgwick that other values or states of affairs besides just pleasure contained goodness, Sidgwick nevertheless correctly appreciated the decisive relevance of taking common sense seriously in justifying utilitarianism. So for Rashdall as for Sidgwick, our common-sense moral judgements help us discover moral truth insofar as philosophizing about the latter needs 
to be more-or-less consistent with the former. For both, common sense is justificatory.

Rashdall also seems to follow Sidgwick, insisting that explanations of the evolution of common-sense morals were nonetheless metaethically irrelevant. Just as the fact that our cognitive faculties developed out of more primitive ones has no bearing whatsoever on mathematical and scientific truth, the fact that our moral faculties also developed out of more primitive ones is wholly irrelevant to the existence and particulars of moral truth. Thanks to Sidgwick and contrary to the exaggerated claims of Spencer, we may hope that the:

time will come when the present craze for extracting ethical theory from a study of the habits of Mollusca and crustacean will be seen to have been as much the passing fashion of an age of biological discovery as Locke's speculation as the possibility of solving moral problems by the aid of Algebra was the passing aberration of a great intellect dazzled by the brilliant vista of possible achievement opened out to his generation by the mathematical discoveries of Newton. ${ }^{38}$

Or more generally, 'No true account of what the moral consciousness actually is can possibly be vitiated by any true account of its genesis. ${ }^{39}$

Now much like Sidgwick, Rashdall does not always keep truths about morality's genesis distinct from claims about moral truth. ${ }^{40}$ More than once, he conflates origin with validity or at least he fudges the distinction between them. For instance, in The Theory of Good and Evil, he says ambiguously that 'the evolutionary history of Morality does supply us with an additional caution against tampering with deeply-seated moral convictions' (my italics) ${ }^{41}$ Spencer's 'doctrine, in so far as it has a sound physiological basis, can at most only slightly reinforce that presumption in favour of established Morality from which the sane Moralist from any school sets out' (my italics). ${ }^{42}$ The 'evolutionary history of Ethics may then supply us with some help - chiefly negative help - towards (as it were) purging our value-judgements of irrelevant matter due to the mere inheritance or tradition or prejudice and the like' (my italics). ${ }^{43}$ And evolutionary theory 'has supplied us with an additional ground for a prima facie confidence in apparently intuitive moral beliefs, while at the same time it has enforced the necessity of asking whether such beliefs have or have not outlived their justification' (first italics mine) ${ }^{44}$ Clearly, in suggesting that established morality and its evolutionary history caution us against tampering with it by providing it with a prima facie presumption 
and helping to ground it, Rashdall concedes that the historical origins of common sense are not without justificatory weight. Origins do indeed bear on validity after all.

Perhaps Rashdall's (and Sidgwick's similar) fudge on whether the history of our moral intuitions contributes to warranting them exposes a quandary faced by all versions of reflective equilibrium. If we dare not ignore our common-sense moral intuitions, however they have come about when we reason morally, then it would seem that the former are necessarily justificatory in some genuine albeit equivocal sense. So much for unalloyed non-naturalism.

\section{Pleasure, happiness and life as a whole}

Rashdall's ideal version of utilitarianism is most distinctive for attributing intrinsic value or goodness itself to a plurality of goods, or perhaps it would be better to say that he attributes intrinsic value to a plurality of virtues or states of affairs. Either way takes him beyond Moore. No doubt, too, either characterization helps make better sense of why Rashdall followed Moore, insisting that good was unanalysable, although Rashdall sometimes seems to imply that good was not just unanalysable but also meaningless. Goods (and virtues) were conceptually meaningful, referring to something real, but not so the concept of 'good'.

In The Theory of Good and Evil, Vol. I, Rashdall says that the morality of our actions is determined by their tendency to promote 'many ends' rather than one end. In some passages, he says these include two especially, namely 'Morality and pleasure'. Elsewhere, he says rather vaguely that morality requires that we promote other goods, including 'dispositions, emotions, activities, states of consciousness which are valued for their own sakes and not merely as a means to some further good'. ${ }^{45}$ And wherever he shifts to the language of virtues instead of goods, he says that acting morally prescribes promoting the exercise of our 'higher intellectual and aesthetic faculties' and controlling our 'lower or more animal impulses' ${ }^{46}$ The former includes particularly the aptitude for seeking truth and speaking truthfully. Volume II of The Theory of Good and Evil blends the language of goods and virtues:

Suffice it once more to remind the reader that, while I do regard pleasure as a good, I do not regard it as the good. It seems to me perfectly clear that the moral consciousness does pronounce some goods to be higher, or intrinsically more valuable than others; and 
that at the head of these goods comes Virtue, while many other things - intellectual cultivation and intellectual activity, aesthetic cultivation, emotion of various kinds - are also good and of more intrinsic value than mere pleasure. It is true that pleasure is an element in every state of consciousness to which we can assign ultimate value. ${ }^{47}$

Now, in claiming that pleasure is an element accompanying every valuable state of consciousness, Rashdall implies that pleasure is the sole good that attends to every other good. The exercise of every virtue is always accompanied by the good of pleasure and, practically speaking, we should be thankful for that. Fortunately for us, pleasure just happens to supervene on all other goods. Wherever one or more other goods are going on, the good of pleasure is going on as well.

So pleasure marks the presence of other goods but not systematically because though pleasure is 'an element in everything to which we attach value', we 'do not attach value to consciousness in proportion to its pleasantness'. ${ }^{48}$ Happiness, however, is a far better marker of the presence of other goods. It is the one good that best signifies the presence of other goods. Though happiness is not identical with the 'end of life', it is nevertheless 'a most important' element in true well-being. It is 'a far more valuable kind of pleasure than any other, and far more inseparable than most other pleasures from the goods to which we ascribe the very highest value' (my italics). ${ }^{49}$ Even though 'men are not happy in proportion to their goodness', just as they do not experience pleasure in proportion to their overall goodness, happiness fortuitously tracks overall goodness better than any other singular good.

Earlier, I suggested Rashdall seems to hold that classical utilitarianism can stand in as a convenient method for determining our moral obligations. We can now see why. If pleasure typically marks the presence of other goods, then maximizing pleasure will also tend to maximize them. And if happiness marks their presence even better, then maximizing happiness can stand in yet more conveniently as a substitute tactic for determining moral rightness. But Moore, as we saw earlier, doubted whether pleasure was a useful, proxy 'criterion' of right action. It would therefore be a 'strange coincidence' if maximizing pleasure also happened to maximize good. Hence, we might expect that Moore would find Rashdall's claims that classical utilitarianism could stand in for ideal utilitarianism problematic. And indeed, Moore faults Rashdall precisely on this score in an obscure review of The Theory of Good and Evil in the Hibbert Journal. There Moore writes that Rashdall thinks that actions 
that 'produce a maximum balance of pleasure might always also produce such other results as would give the total a maximum of intrinsic value'. Moore avers that Rashdall errs in assuming this coincidence. Indeed, as Moore remarks, Rashdall himself sometimes concedes as much insofar as he 'appears to hold that cases do sometimes actually occur in which it is wrong to do an action whose total results are likely to contain a maximum balance of pleasure'. Rashdall, then, recognizes the implausibility of the 'view that it always would be right, no matter what the consequences might be in other respects, to do any action which would produce a maximum of pleasure'. ${ }^{50}$

Notwithstanding how much Rashdall differed from Moore in terms of how closely pleasure as an element of goodness tracked overall goodness, Rashdall and Moore differed less about goodness itself. But for Rashdall, despite good being indefinable (perhaps because goodness by itself does not exist, making the concept nonsense), there was still such a thing as an 'ideal end of life', which does not consist of a bunch of higher and lower goods 'piled together' but rather is an interconnected 'whole made up of distinguishable elements - a good made up of an hierarchy or ascending scale of goods'. ${ }^{51}$ This 'ideal life or the good is an ultimate conception which does not admit of further definition, and the content of which we can only express by enumerating the various elements or aspects of it, and then explaining in what way they are to be combined'. ${ }^{52}$ Good, then, may not be quite unanalysable after all. It's just that we cannot say much about it other than analysing individually and connecting hierarchically the separate goods constituting it. The more we try to get a hold of it conceptually, the more it slips away, but there really is something complex and very significant there.

Here we return to Green. Rashdall's conception of an ideal life as whole, and the place of pleasure and happiness in it, is seminal for Green as well. Surely, Rashdall was a careful enough reader of Green not to miss just how importantly intertwined these notions were. (Recall, after all, that Rashdall dedicated The Theory of Good and Evil to Green and Sidgwick both.) As I have argued at length in Utilitarianism and the New Liberalism, Green was what we would label a non-hedonistic consequentialist, for whom promoting self-realization, particularly our moral dispositions, was the criterion of moral rightness. And for Green, as previously noted, insofar as pleasure typically accompanies self-realizing activities, aiming at maximizing pleasure turns out to be a pretty good proxy for promoting self-realization. In other words, classical utilitarianism, especially Mill's version, could be substituted in place of the kind of practical reasoning Green favoured. 


\section{Rightness}

As I have been stressing, Rashdall was an ideal utilitarian like Moore and, if we follow Hurka, like McTaggart as well. ${ }^{53}$ Like them, he combined a consequentialist theory of right but with a pluralistic account of good. That is, he held that the morality of actions is determined solely by the goodness of the state of affairs produced and that the goodness of the latter consisted not just in the good of pleasure but in various other goods as well. ${ }^{54}$ As Rashdall declares: 'According to this view (ideal utilitarianism) actions are right or wrong according as they tend to produce for all mankind an ideal end or good, which includes, but is not limited to, pleasure. ${ }^{55}$ And as he often insists, as we have already seen, the ideal or good for man is not a number of goods lying side by side and having no relation to one another, but a particular kind of life in which various elements are harmoniously combined. ${ }^{56}$

But unlike Moore, Rashdall was just as preoccupied with rightness as with goodness. In this regard, he looked back more to Sidgwick, who, as we saw earlier, was far more invested in determining what we ought to do than he was in defining or analysing good. Indeed, for Rashdall, rightness was fundamentally axiomatic.

Rashdall frequently refers to his consequentialist theory of right as the axiom of rational benevolence, which is to say that for him it is ' $a$ priori' or 'self-evident'. For a judgement to be self-evident $a$ priori means that there is 'an element of knowledge which cannot be explained as sensation or any generalization from sensation'. ${ }^{57}$ Such a judgement is 'as inexpugnable a notion of the human mind as the notion of quantity or cause or substance or the like ... ${ }^{58}$ Likewise, referencing Sidgwick, he insists that rational prudence and 'equity or justice' are also independent, self-evident normative axioms. ${ }^{59}$ Whereas rational benevolence and rational prudence prescribe how good is to be promoted, equity prescribes how it should be distributed. Obviously, insofar as Rashdall deems rational prudence and equity self-evident axioms in addition to rational benevolence, he opens his consequentialist theory of right to a host of problems that go beyond Sidgwick's anxiety about the dualism of practical reasoning. Designating equity a third self-evident axiom of right adds another layer of complication, making his practical reasoning arguably no longer solely consequentialist.

Rashdall regards equity as an independent, normative axiom of great importance. His discussion of how we should understand this axiom is often confusing and is quite different from Sidgwick's counterpart conception of it. Rashdall begins his chapter on 'Justice' in the 
first volume of The Theory of Good and Evil stipulating that we 'want a principle to guide us as to the distribution of good among the various persons capable of enjoying it'. Bentham's principle that 'everyone is to count for one and nobody for more than one' is not a bad starting point when somewhat modified as 'Everybody's good [is] to be treated as of equal value with the like good of every one else'. ${ }^{60}$ Rashdall next spends much of the chapter reformulating equity variously. For instance, he says that by equity, 'what the individual is entitled to is simply equality of consideration'. And he also says, 'The principle of equal consideration certainly requires us to aim at the greater equality of actual Well-being, but only on condition that the greater equality will not violate the equal right of each to enjoy as much good as it is possible for him to enjoy. ${ }^{61}$ Now, these formulations are palpably not identical. For instance, being equally considered does not necessarily entail that one's good is indeed being treated with equal value. I may consider others equally by treating them equally badly without treating their good equally at all. Certainly, equal consideration does not entail that I promote 'greater' equality of 'actual' well-being. Moreover, the 'equal' right to enjoy as much good as it is 'possible' to enjoy would seem remarkably over-demanding. Matters only get messier for Rashdall where he casts equity in terms of equal opportunity. For instance, citizens are owed the 'opportunity for the freest and most fruitful exercise' of their 'highest capacities - their exercise in such a way as shall be most favourable both to the goodness itself and to the pleasure which, under favourable circumstances, goodness brings with it'. They require 'room for initiation, for selection, for choosing what to do or not to do ... '.62 And recalling Bosanquet, Rashdall observes that it is the 'supreme condition of a truly moral system of property-distribution that it shall be the one most favourable to the cultivation and development of the highest individual characters'. ${ }^{63}$ Notice that here property should be distributed not according to what promotes everyone's highest capacities, but according to what promotes the capacities of those whose capacities happen to be the highest. So equal consideration really prescribes 'equality of treatment when capacities are equal, treatment in proportion to the intrinsic worth of the capacity when they are unequal. ${ }^{64}$

Rashdall, then, conjoins a non-hedonistic or idealist theory of good with a compound, axiomatic theory of right. He combines what preoccupied Moore with what earlier preoccupied Sidgwick. And he also looked back to Green. There is far more nuance to the story of ideal utilitarianism than just Moore, his critics and his subsequent reformulated views about the naturalistic fallacy. ${ }^{65}$ 
Finally, when we recall Mackenzie's allegation noted previously that the only 'real difference' between Moore and his idealist adversaries such as Green and Bradley 'seems to lie in his contention that Good cannot be defined', we have all the more reason to insist that the story of ideal utilitarianism is far more knotty than the current received view would have it. If Mackenzie's claim has even some merit, then Rashdall, as well as Moore, has more in common with idealists than we now assume, suggesting that ideal utilitarianism and idealism were hardly implacable antagonists.

\section{Conclusion}

For, beyond somewhat narrow limits, there seems no ground for determining what a philosopher actually thought except a judgment of what is right to think. The other method put forward now, especially in Germany, as 'history of development' rests in the end on this. It is true that much light may be thrown on what a man thought by discovering what his predecessors thought; but our view of what they thought must again be determined largely by our view of what can be thought [my italics].

If he [Kant] had seen it [the contradiction between two propositions], he would have been forced to choose between them; and it belongs to the historian's province to determine which he would have chosen, since that would depend upon what he thought to be the real significance of his system. And in this determination the historian must assume that Kant would have been influenced, to some extent, by the same arguments which appear conclusive to him. Failing this assumption, it would be impossible for him to declare what was the essential contention upon which the philosopher really means to insist [my italics].

G. E. Moore, '1898 Fellowship Dissertation'

When Moore revised his '1897 Fellowship Dissertation' and resubmitted it a year later as his '1898 Fellowship Dissertation', he added the above to the 'Introduction'. Presumably he added the above, which was part of a supplementary clarification of his approach to reading past philosophical texts, in response to Edward Caird's critical report on the earlier dissertation. Caird had disparaged Moore severely for conflating his own views with the views of those he criticized, such as Kant and Sidgwick. Moore, that is, failed utterly to interpret Kant and Sidgwick correctly, turning their thinking into what Moore held they should have thought. So, for 
Moore, at least in 1898, when encountering an inconsistency in Kant, apply the following principle: Whenever we can imagine Kant approving our corrections to his arguments, we can conclude that this was what he actually thought.

When practising the history of philosophy, we should eschew arguing with historical texts as if we were quarrelling with each other. Rosen's scholarship is testimony to this principle. We would do best to avoid speculating how, for instance, Rashdall could respond to any number of our criticisms of him. We should not say what Robert Shaver says in defence of Rashdall for purportedly having violated 'ought' implies 'can', namely in 'reply, Rashdall might say that he is relying on a sense of "ought" that does not imply "can"' (my italics). ${ }^{66}$

As a first step, then, we should focus on how authors of these texts who were contemporaries argued with each other. Next, we should attend to how they argued, or appropriated, those who immediately preceded them, keeping in mind that they probably misread their predecessors much like we misread them by arguing with them as if they were our contemporaries.

That is to say, when we read Moore, we should read the whole of Principia Ethica carefully and not just the opening chapter where Moore introduces and explains the naturalistic fallacy. We should at least also read the middle chapters where Moore engages Spencer, Mill, Sidgwick, Kant and Green in the guise of Mackenzie. We should then follow through by examining no less carefully the last two chapters, particularly where Moore defends his version of ideal utilitarianism. And we should, furthermore, read the 'Preface to the Second Edition' of Principia Ethica as well as Moore's '1897 Fellowship Dissertation' and '1898 Fellowship Dissertation'. We should read, despite its inferiority to Principia Ethica, Rashdall's The Theory of Good and Evil and a bit of McTaggart to boot. Spencer, Mill, Sidgwick, Kant and idealists such as Green and Mackenzie were in Moore's sights primarily when he wrote Principia Ethica. They constituted the context of his immediate philosophic discourse, and Rashdall's too. Rashdall pretty much takes up the very same contemporaries and immediate predecessors as worthy of criticism. Likewise, Rashdall and McTaggart are crucial because they built on Moore in assembling what we have since come to characterize as ideal utilitarianism. If we want to understand just Moore's version of ideal utilitarianism, then we need to come to terms with Rashdall and McTaggart's versions lest we conflate them all into one muddled mess of inheritance. 
I would further like to re-emphasize that because Rashdall dedicates The Theory of Good and Evil to both Green and Sidgwick and interprets himself as combining the best of both, we have all the more reason not to exaggerate the differences between classical utilitarianism and idealism, which it provoked in response. ${ }^{67}$ No doubt as well, and to repeat, we do best not to overdramatize the differences between idealism and ideal utilitarianism. I suspect that our contemporary predilection for drawing sharp analytical dichotomies drives some of this overdramatization which is just another way of saying that analytical philosophers should tread more carefully whenever they engage in the history of philosophy.

But I would concede, as I surmise Rosen would as well, that however much idealists such as Green and Bradley and ideal utilitarians like Moore and Rashdall saw themselves as slaying their predecessors and however much we have subsequently bought into this melodramatic narrative of their intentions, we should not forget to pay sufficient attention to the actual substance and effectiveness of their criticisms. We should no less avoid fetishizing authorial intentions than we should recklessly reconstruct texts out of context.

\section{Notes}

1. Frederick Rosen, Mill (Oxford: Oxford University Press, 2013), vii.

2. Rosen, Mill, 2.

3. As far as I know, Moore never used the terminology 'ideal utilitarianism' to refer to his genre of utilitarianism. Rashdall seems to be the first philosopher to describe his version of utilitarianism accordingly. See especially Hastings Rashdall, Ch. VII, 'Ideal Utilitarianism' in The Theory of Good and Evil: A Treatise, Vol. I (Oxford: Clarendon Press, 1907). The chapter includes a long discussion about why ideal utilitarianism best captures the novel utilitarianism he defends. $\mathrm{He}$ considers as alternatives 'Non-hedonistic' utilitarianism, 'Idealistic' utilitarianism (which unfortunately suggests 'a metaphysical' as opposed to a 'purely ethical' position), 'teleological Ethics' and 'Eudaemonistic Ethics'. Ideal utilitarianism is superior because it reminds us that 'the good for which we seek is not a conception got by abstraction from a number of empirically given experiences of pleasure or pain, but an ideal set up by rational judgement of value passed upon all the elements of our actual experience' (218). Rashdall also says that Moore 'is a striking expression' of the same view he endorses (217, note 2). McTaggart among the neo-Hegelians qualifies too as does the 'distinguished German thinker, Eduard von Hartmann' (217-8, notes 2 and 4).

4. W. J. Mander, British Idealism: A History (Oxford: Oxford University Press, 2011), 2.

5. Jennifer Welchman, 'G. E. Moore and the Revolution in Ethics: A Reappraisal', History of Philosophy Quarterly 6 (1989): 317.

6. Bernard Bosanquet, 'Critical Notice: Principia Ethica', Mind 13 (1904): 261.

7. Welchman suggests that the idealists by and large did not even find Moore especially provocative or the least bit damaging. According to her, the 'idealists ... were even more at home with the specific doctrines espoused in the Principia than were Moore's realist supporters'. Contrary to recent assumptions, there 'are no indications that idealists viewed Moore's criticisms of idealist ethics as serious objections to their own theories'. See Welchman, 'G. E. Moore and the Revolution in Ethics', 322. Perhaps naturalists such as Spencer and Mill and non-naturalists 
like Sidgwick might likewise have found themselves no less 'at home' with Moore than we now assume. But we will never know since they were all dead by the time Principia appeared in 1903. Though Green was dead, too, many idealists, including Bosanquet and J. S. Mackenzie, were still very much alive and therefore did respond to Moore.

8. For Moore's critical account of Spencer, see my Equal Freedom and Utility (Cambridge: Cambridge University Press, 1998), Ch. 6.

9. For Green's rivalry with Sidgwick, see my Utilitarianism and the New Liberalism (Cambridge: Cambridge University Press, 2007), 54-5.

10. G. E. Moore, Principia Ethica (Cambridge: Cambridge University Press, 1903), 59.

11. Henry Sidgwick [1907], The Methods of Ethics, seventh edn. (London: Hackett, 1981), 1. For Phillips's view that Sidgwick was not so much interested in goodness as he was in what we ought to do, see David Phillips, Sidgwickian Ethics (Oxford: Oxford University Press, 2011), 35-6. Phillips also concludes that because Sidgwick was not much preoccupied with goodness or with defining it, his non-naturalism was superior to Moore's $(35,38)$.

12. Moore, Principia Ethica, 84-5, 89.

13. Moore, Principia Ethica, 107.

14. Moore, Principia Ethica, 62.

15. Moore, Principia Ethica, 90.

16. Moore, Principia Ethica, 91-2.

17. In addition, given the practical difficulties of estimating all of the short- and long-term results of our actions, we have all the more reason to abandon pleasure as a normative criterion: 'And, since the practical guidance afforded by pleasure as a criterion is small in proportion as the calculation attempts to be accurate, we can well afford to await further investigation, before adopting a guide whose utility is very doubtful and whose trustworthiness we have grave reason to suspect' (Moore, Principia Ethica, 108). But see Moore's earlier 'Appendix: Professor Sidgwick's Hedonism', which concludes his '1897 Fellowship Dissertation', in G. E. Moore, Early Philosophical Writings, ed. Thomas Baldwin (Cambridge: Cambridge University Press, 2011), 91, where he says: 'I do not, indeed, think that the danger from Utilitarianism is very great, partly because I accept the common sense judgment that pleasure is, in itself, better than pain, and to be sought so far as it does not hinder the pursuit of still better ends; but chiefly because the application of the hedonistic calculus seems, in all the most important matters, to yield whatever conclusion would have been maintained without it, owing to the uncertainty both of measurements of pleasure and of calculation of results. But I shall presently give reasons for thinking that, in proportion as it is made more capable of application, it will give results more and more divergent from those of Common Sense and those which I myself intuitively judge to be true.'

18. For Mackenzie's assessment of Moore, see his 'Book Review of Principia Ethica', International Journal of Ethics 14 (1904): 377-82. Note especially Mackenzie's comment that the only 'real difference' between Moore and idealist adversaries 'seems to lie in his contention that Good cannot be defined' (382).

19. Moore, Principia Ethica, 113-14. Metaphysical versions of the naturalistic fallacy no less than Spencer, Mill and Sidgwick's evolutionary and hedonistic versions are proved fallacious in as much as the so-called 'open question' argument applies no less forcefully to them as well. That is, for 'whatever we may have proved to exist, and whatever two existents we may have proved to be necessarily connected with one another, it still remains a distinct and different question whether what thus exists is good; whether either or both of the two existents is so; and whether it is good that they should exist together' (126).

20. Moore, Principia Ethica, 138.

21. Moore, Principia Ethica, 138.

22. Mander, British Idealism, 479.

23. Moore, Principia Ethica, 139.

24. Rashdall, The Theory of Good and Evil, Vol. I, vi-vii.

25. Hurka considers it significant that Rashdall dedicated The Theory of Good and Evil to both Green and Sidgwick, insisting that Rashdall sought to combine Sidgwick's methodological devotion to analytical clarity and his consequentialism with Green's perfectionist theory of value. Hurka also notes that Sidgwick regarded Rashdall as 'one of his ablest critics', that Rashdall and McTaggart held each other in high esteem, with the latter having read The Theory of Good and Evil in draft, and that Rashdall considered Principia Ethica to be superb, though Moore 
both criticized and praised Rashdall's writings. See Thomas Hurka, British Ethical Theorists from Sidgwick to Ewing (Oxford: Oxford University Press, 2014), 9.

26. Hurka also holds that the Sidgwick-to-Ewing school was 'non-cognitivist' insofar as they regarded meta-ethical claims and normative judgements as 'in the present-day terminology, truth apt' (Hurka, British Ethical Theorists, 86). We should be careful, however, in attributing 'present-day' terminology when interpreting past philosophical texts. As I never tire of stressing, doing this sort of thing risks reading past philosophers in ways they would not have recognized and might well therefore reject. But Hurka is correct in reminding us that non-naturalistic moral realism is enjoying a resurgence in the views of Derek Parfit, Thomas Nagel and Russ Shafer-Landau. I would add Peter Singer to this list.

27. See Rashdall, The Theory of Good and Evil, Vol. II, 2, where Rashdall says that Mackenzie has 'performed a real service by putting' Green's (and Bradley's) 'doctrine into a form in which it is easier to subject it to examination and criticism'. See also page 35, where Rashdall attacks Mackenzie as a surrogate for criticizing Green and other idealists because their 'modesty prevents them putting their views into a form in which they can be criticized'.

28. Rashdall, The Theory of Good and Evil, Vol. II, 6. For Rashdall's inconsistent claims about Green, see 2 and 5.

29. Rashdall, The Theory of Good and Evil, Vol. II, 6-7.

30. Rashdall, The Theory of Good and Evil, Vol. II, 23, 25. Comparing and judging amounts of pleasure is no less onerous than judging competitions. Rashdall writes: 'If a prize were offered to the host who would give us most pleasure in the course of six entertainments with or without a certain limit to the expense, the judges in such a competition would, I imagine, have to order their impressions of each entertainment in some such way - very much as a man who is judging poems quite intelligibly (though I do not recommend the method) arrives at his decision by assigning so many marks for language, so many for ideas, so many for rhythm, and so on' (24). And of course this sort of thing is done all the time in judging sporting competitions, particularly Olympic ones.

31. See my Utilitarianism and the New Liberalism, Ch. 2, for Sidgwick's similar response to Green.

32. Rashdall, The Theory of Good and Evil, Vol. II, 15.

33. Rashdall, The Theory of Good and Evil, Vol. I, 37.

34. Rashdall, The Theory of Good and Evil, Vol. II, 20. Elsewhere in Vol. II, Rashdall accuses Green and Bradley of indulging in unintelligible 'mysticism' insofar as both purportedly 'include any realization of the capacities of others in our conception of self-realization, however essential to such realization the good of others may be'. If the self-realization of others is essential to my self-realization, then they are simply a means to my ends, making their self-realization not an end-in-itself and therefore not genuine self-realization (for them). Rashdall continues that even if there be a more ultimate metaphysical sense in which my self and others are really the same self, that is not the sense with which we have to do with selves in Ethics: in Ethics at least we are concerned with the relations between a plurality of selves'. He then adds that with 'others it is a mere cover for a more or less refined Hedonism'. In Utilitarianism and the New Liberalism, I have argued at length about the extent to which the new liberalism and British idealism were distilled and disguised utilitarianism. No doubt Rashdall's accusation that the mysticism swirling around equating or defining good with self-realization is bound up with his agreement with Moore that good is unanalysable, which I turn to momentarily.

35. Hastings Rashdall, Is Conscience an Emotion? (Boston: Houghton Mifflin, 1914), 143-5.

36. Rashdall, Is Conscience an Emotion?, 149-50.

37. Rashdall, The Theory of Good and Evil, Vol. I, 49.

38. Hastings Rashdall, 'Professor Sidgwick's Utilitarianism', Mind 10 (1885): 203-4. And see Rashdall, The Theory of Good and Evil, Vol. II, 399, where Rashdall says, again primarily with Spencer in mind, that it "would be as absurd to talk about the "struggle for existence" and "natural selection" as constituting by themselves the "origin" of our moral ideas as it would be to treat the cane of the schoolmaster as being the "origin" of our geometrical ideas, as though there may be persons in whom these ideas would never have been developed without that agency'. Most of Chapter IV of Vol. II, entitled 'Morality and Evolution', is aimed at Spencer. Likewise, much of Chapter II, 'The Morality of Savages', from his later Is Consciousness an Emotion?, disparages Spencer. But it also criticizes Edward Westermarck and William McDougall, whose work Rashdall first read as The Theory of Good and Evil was going to press. It is worth noting that Rashdall regards far more favourably L. T. Hobhouse's account of the bearing of 
evolutionary explanations of morality on moral reasoning. See Rashdall, The Theory of Good and Evil, Vol. II, 357, note 1, and Is Consciousness an Emotion?, 83. And see my Utilitarianism and the New Liberalism, Ch. 3, for an in-depth discussion of Hobhouse's rational utilitarianism.

39. Rashdall, The Theory of Good and Evil, Vol. II, 357. And as Rashdall would later put it in Is Conscience an Emotion?, 73, the 'late appearance of a notion in the historical development of the human mind has nothing to do with the question of its validity ...' (my italics). Rashdall then continues, much like in his earlier The Theory of Good and Evil, Vol. II, that the 'validity of the multiplication table is [un] affected by the discovery (if discovery it be) that some savages cannot count more than five, or by the undeniable fact that we have all passed through a mental stage of mental development in which we could not count even up to five' (73-4).

40. See my unpublished manuscript, 'The "General Presumption" Afforded by Evolution', for a detailed discussion of Sidgwick's account of the bearing of the evolutionary origins of morality on its validity.

41. Rashdall, The Theory of Good and Evil, Vol. II, 401.

42. Rashdall, The Theory of Good and Evil, Vol. II, 377.

43. Rashdall, The Theory of Good and Evil, Vol. II, 409.

44. Rashdall, The Theory of Good and Evil, Vol. II, 411.

45. Rashdall, The Theory of Good and Evil, Vol. I, 188.

46. Rashdall, The Theory of Good and Evil, Vol. I, 192.

47. Rashdall, The Theory of Good and Evil, Vol. II, 37.

48. Rashdall, The Theory of Good and Evil, Vol. II, 38.

49. Rashdall, The Theory of Good and Evil, Vol. II, 59.

50. G. E. Moore, 'Review of The Theory of Good and Evil', The Hibbert Journal 8 (1907-8): 449. Also see 450, where Moore says that what 'certainly is true is only that of two results, which differ in no respect except quantity of pleasure, the one, nevertheless, very often, has much more intrinsic value than the other'. In short, intrinsic value and pleasure do not necessarily track each other.

51. Rashdall, The Theory of Good and Evil, Vol. II, 57. See also Rashdall, The Theory of Good and Evil, Vol. I, 220, where Rashdall observes following Moore's account of organic unities, 'Undoubtedly the elements are altered by their relations, just as the notes of a chord or the instruments of an orchestra produce together an effect which is different from what each of them produces by itself. But there could not be musical notation unless we could distinguish these elements and speak of the whole - the chord or the harmony - as produced by their combinations.' Note that suggesting the best life consists of a hierarchy of ascending goods implies that goods are commensurable. Indeed, Rashdall's discussion of an ideal life as a whole occurs in a chapter entitled 'The Commensurability of All Values'. We can now better appreciate why Rashdall was so keen to refute Green's insistence that maximizing pleasure was incoherent because pleasures could not be ranked as they were incommensurable. If something far more basic than pleasures was incommensurable and impossible to rank, then trying to compare, rank and systematize multiple intrinsic goods into a whole ideal life would seem no less impossible.

52. Rashdall, The Theory of Good and Evil, Vol. II, 60. Rashdall then lists various goods that make for an ideal life as a whole. These are 'good will, knowledge, thought, the contemplation of beauty, love of other persons and of what is the best in them'. Here, Rashdall's inventory of intrinsically valuable goods echoes more closely Moore's.

53. For McTaggart's ideal version of utilitarianism, see J. M. E. McTaggart, The Nature of Existence, Vol. II (Cambridge: Cambridge University Press, 1927).

54. See also Rashdall, The Theory of Good and Evil, Vol. II, 219, where he says that the 'morality of our actions is be determined ultimately by its tendency to promote a universal end, which end itself consists of many ends, and in particular two - Morality and pleasure'. Presumably by 'Morality', Rashdall means multiple goods, otherwise his principle of right would be half tautological. But see Rashdall, Is Conscience an Emotion?, 44, where he adds other ends, namely 'intellectual activity, aesthetic culture, and the like' to his list of goods.

55. Rashdall, The Theory of Good and Evil, Vol. I, 184.

56. Rashdall, The Theory of Good and Evil, Vol. I, 220. Recall Rashdall's discussion of how the notes of a chord generate an effect qualitatively different from what each note would produce in sequence.

57. Rashdall, The Theory of Good and Evil, Vol. II, 356.

58. Rashdall, Is Conscience an Emotion?, 39. 
59. See, for example, Rashdall, Is Conscience an Emotion?, 41-2, where Rashdall quotes from The Methods of Ethics in which Sidgwick discusses these three axioms. After endorsing Sidgwick's axioms, Rashdall says, curiously, that these axioms of right are implied in the idea of good. Indeed, they 'both involve the same single analysable idea which can expressed in many ways but can never be defined ...' (46). See 181-3, where Rashdall discusses rational benevolence and equity as axioms, again referencing Sidgwick. He claims that, among other things, perceiving benevolence and equity as axioms testifies to their 'rational, objective character'.

60. Rashdall, The Theory of Good and Evil, Vol. I, 222.

61. Rashdall, The Theory of Good and Evil, Vol. I, 226, 234.

62. Rashdall, The Theory of Good and Evil, Vol. I, 258, 276.

63. Rashdall, The Theory of Good and Evil, Vol. I, 277.

64. See also Rashdall, The Theory of Good and Evil, Vol. I, 255, where he says that because the 'higher good is worth more than the lower good', the 'man who has more capacity for higher good should count for more than the man who has less'. Those who are more talented deserve more opportunities to cultivate their superior talents. Finally, whatever equal consideration amounts to, it does not mean equal freedom in Spencer's sense either: 'To my own mind the principle that "every man is free to do that which he wills, provided he infringes not the equal freedom of any other man" is as self-evidently absurd as to Herbert Spencer it as self-evidently true.' Contrary to Spencer, the 'idea that "compulsion" is avoided by the absence of State interference is a delusion'. The 'workman who is compelled to accept subsistence wages under penalty of starvation is just as much "compelled" or "interfered with" as if he were threatened with imprisonment by the State'. And a 'labourer without Capital is about as free to appropriate the value of his labour as a lame man without crutches is free to walk' $(391,393)$. Again, as with Green, Sidgwick, Moore and many others of Hurka's 'school', Spencer was very much on Rashdall's mind.

65. G. E. Moore, Principia Ethica, ed. Thomas Baldwin (Cambridge: Cambridge University Press, 1994).

66. Robert Shaver, 'Prichard's Arguments against Ideal Utilitarianism', Utilitas, FirstView, 17. Though a fine account of Prichard's often obtuse criticisms of ideal utilitarianism, Shaver's essay offers several hypothetical ways of how Rashdall 'might' respond to criticisms Shaver raises. See 17-18. Shaver also speculates how Prichard 'might' respond to objections that ideal utilitarians might have made to his criticisms of Moore. See 10. Shaver notes, too, on 15 that it is 'striking that the arguments I have considered in this section and the previous two - arguments that dominate the debate now - get so little attention from later Prichard'. But why should we be all that surprised that Prichard missed arguments that now preoccupy us?

67. My Utilitarianism and the New Liberalism tried hard to demonstrate that the disparities between classical utilitarians such as Mill and Sidgwick on the one hand and idealists and new liberals like Green, Hobhouse, Ritchie and Hobson on the other have been overblown.

\section{Bibliography}

Bosanquet, Bernard. 'Critical Notice: Principia Ethica', Mind 13 (1904): 254-61.

Hurka, Thomas (ed.). Underivative Duty: British Moral Philosophers from Sidgwick to Ewing. Oxford: Clarendon Press, 2011.

Hurka, Thomas. British Ethical Theorists from Sidgwick to Ewing. Oxford: Oxford University Press, 2014.

Mackenzie, J. S. 'Book Review of Principia Ethica', International Journal of Ethics 14 (1904): 377-82.

Mander, W. J. British Idealism: A History. Oxford: Oxford University Press, 2011.

McTaggart, J. M. E. The Nature of Existence, 2 vols. Cambridge: Cambridge University Press, 1927.

Moore, G. E. Early Philosophical Writings. Edited by Thomas Baldwin. Cambridge: Cambridge University Press, 2011.

Moore, G. E. Principia Ethica. Cambridge: Cambridge University Press, 1903.

Moore, G. E. Principia Ethica. Edited by Thomas Baldwin. Cambridge: Cambridge University Press, 1993.

Moore, G. E. 'Review of The Theory of Good and Evil', The Hibbert Journal 8 (1907-8): 446-51.

Phillips, David. Sidgwickian Ethics. Oxford: Oxford University Press, 2011. 
Rashdall, Hastings. Is Conscience an Emotion? Boston: Houghton Mifflin, 1914.

Rashdall, Hastings. 'Professor Sidgwick's Utilitarianism', Mind 10 (1885): 200-26.

Rashdall, Hastings. The Theory of Good and Evil: A Treatise on Moral Philosophy, 2 vols. Oxford: Clarendon Press, 1907.

Rosen, Frederick. Mill. Oxford: Oxford University Press, 2013.

Shaver, Robert. 'Prichard's Arguments against Ideal Utilitarianism', Utilitas 30.1 (2018): 54-72.

Sidgwick, Henry [1907]. The Methods of Ethics, seventh edn. London: Hackett, 1981.

Weinstein, David. Equal Freedom and Utility. Cambridge: Cambridge University Press, 1998.

Weinstein, David. 'The “General Presumption" Afforded by Evolution', unpublished manuscript.

Weinstein, David. Utilitarianism and the New Liberalism. Cambridge: Cambridge University Press, 2007.

Welchman, Jennifer. 'G. E. Moore and the Revolution in Ethics: A Reappraisal', History of Philosophy Quarterly 6 (1989): 317-29. 


\section{Index}

activity 89, 101, 103, 104, 167 active character 207

adaptation 118, 122, 129-32

agrarian labour 12-13, 269-75, 279, 280, 283, 284, 285

Alembert, Jean le Rond d' 21, 22

Alexander, Mrs Cecil 242

Alexander, Edward 13, 246-7, 251

Allen, William 12, 271, 273, 274-8, 279, 280, 281, 282, 283-4

allotments 275, 276, 284

America 12 see United States of America

Ancient world 65, 74, 133, 166, 233;

annual elections 11, 47, 55

Aristippus 64

Aristotle 100, 101, 103, 105, 108, 150, 163, 167, 230, 233

Arneil, Brbara 12-13, 269-88

Arnold, Mathew 246

Arnold, Thomas 246, 247, 262

'art of life' 4, 207

ascetics 185, 186

assemblies 28-30,

association of ideas 10, 60, 61, 72, 176

Athens and democracy 226, 235, 236, 241, Atlantic Charter 151

\section{Barbeyrac, Jean 61}

Bain, Alexander 165

Balbus, Lucius Cornelius 77

Ball, Terence 163

Bartels, Larry 226, 239

Bayle, Pierre 59-60, 64, 167

Beattie, James 59, 87

Beccaria 67, 68

Bell, Andrew 162, 163, 170

benevolence $24,27,62,68,72,83,111,112$, 170, 303,

Bentham, Jeremy 1, 4-6, 8-9, 10-11, 14, 16, 20, 21, 22, 23-33, ch. $3,59,74$, ch. 5, $119,125,143,162-3,169,174,184$, 186, 187, 188, 192, 193, 194, 274, 304

Bentham Project 2

Bentham Newsletter/Utilitas 2

capabilities ch. 7

greatest happiness principal 8, 20, 21, 23, $41,67,68,76,108,112,129,155,170$, $185,202,208,212,216$

law 154 rights/nonsense upon stilts 5, 22, 143, 152, 153

on Spain see ch. 3 ,

on Hume 66-70, ch. 5

pleasure ch. 11 .

primary and secondary principles 155, 156

property 68-9

security 154-5

self-interest 186-8, 190, 191

subordinate ends $6,125-6,128,134,143$, 154

see also adaptation

Berlin, Isaiah 146, 147, 149-50, 231

Bismarck, Otto von 240

Black, John 164

Blackstone, Sir William 86

Blair, Hugh 63, 166, 167

Bosch, Jan van den 273

Booth, William 12, 13, 271, 273, 278-84

Bosanquet, Bernard 290, 304

Boswell, James 77

Bowring, John 33, 187

Bradley, F. H. 290, 305, 307

Brazil 53, 55

Broad, C. D. 296

Brodie, George 76

Brown, J. 282

Buckley, William 225, 233, 238

Burke, Edmund 145, 146, 154

Burlamaqui, Jean Jacques 31

Burns, J. H., 2

Caird, Edward 305

Callicles 235

Canada 273, 281

capabilities 16, 118, 120-6, 132, 134, 147

Carlyle, Thomas 185

Carrit, E. F. 296

Cassin, René 151

Cato 62, 74

Central and South America 11, 41

Charles 176

Charvet, John 15, 207-224

Chinese 209, 221, 253

Churchill, Winston 151

Christianity 14, 99, 247, 250, 254-7, 258, 259, $262,274,284$

Cicero 7, 9, 62-3, 74, 77, 108, 163, 165-9, 172-3, 176, 177, 228, 233

civilization 69, 174, 210, 211, 212-14, 220, 253 
class warfare 229-30

Cleanthes 77

colonies, home 12-13, 269-88; overseas 11, $40,42,43-5,48,55,56$

Comte, Auguste 3, 77, 225, 255

Condillac 104, 246

Condorcet, Jean-Antoine-Nicholas, Marquis de $4-5,21-34$

Sophie de Grouchy 22

Constant, Benjamin 33, 226, 232

constitutional design 10; Cadiz 10, 41-56

corruption 12 , 29, 43, 46, 65, 228, 236, 241, 270

Cotta 77

Coustures, Baron de 64

Crisp, Roger 7-8, 85, 90, 98-117, 133, 135

Crousaz, Jean-Pierre de 59-61

Cumberland, Richard 108

Cyrenaics 64

Dahl, Robert 226

Dalzel, Andrew 165-6

d'Eichthal, Gustave 249, 252

De Champs, Emmanuelle 4-5, 6, 20-39

Debs, Eugene 229

Declaration of Independence (USA, 1776) 31, $52,150-1,154,247$

Declaration of Independence (Israel) 264

Declaration of the Rights of Man and of the Citizen (France 1789) 22, 30, 31, 143, 151

(Universal) Declaration of Human Rights (UN, 1948) 151-2, 153

deliberation 29, 30, 172

democracy, political vs social $6,11,16,42,56$, 145, 151, 226-8, 229-34, 235-41,

Demosthenes 163

deputies 29-30, 44, 46-7, 53

desire 7, 46, 62-3, 88, 100, 102, 107, 109, 123-4, 129-30, 161, 164, 171-4, 179, 190-2, 199-202, 219-20, 254, 294, 297

despotism 11, 32, 42-4, 47, 52, 53, 55-6, 65, 155,190

Dewey, John 226, 229, 233

dignity $8,43,46,109-11,176,186,190$, 199-200, 256

Diogenes Laërtius 163

Dube, Allison 127

Dumont, Etienne 22

Dunn, John 3

Dworkin, Ronald 129, 234

East India Company 164, 226, 263

Edgeworth. Maria 278

education $5,9,10,25,27,71-2,84,113,122$, $130,161,163,166,169-72,173-4,176$, 248, 256, 260-1, 262, 274, 283.

Egyptians, 253

elections $29,44,47,53,156,175,226-7$, see annual elections

elements ('dimensions') of value 194-5, 211

Enlightenment, the 1, 21, 28, 108, 274

Epicurus 75, 169, 179

Epicureanism 6-7, 14, 59, 164, 185-6, 191, equal interests 15 equality $15,27,31,53,65,118,120,122,124$, 129, 143, 155-6, 207, 208, 210, 212-3, 214-7, 229, 247;

equality of condition 235, 241

equality of opportunity 227, 304

political, civil and religious equality 5,14 , $33,231,232,235,236,258,260,262$, 264, 304

subordinate end/secondary principle 125-9, Escamilla-Castillo, Manuel 5-6, 143-60 Estlund, David 226

European Convention of Human Rights 226 European Court of Human Rights 227

evolutionary ethics 296, 299

Ewing A. C. 295

fame, love of 60, 63, 200-1

Fayle, Joshua 276

fear and want 146-8, 152, 156

Fenn, Robert 163

Ferdinand VII, king of Spain 41, 56

Ferguson, Adam 7, 59, 61, 63-6, 77, 166-7

fidelity/fidélité 29, 83, 91

Finlayson, James 165

fools 1, 14, 172, 185, 186-7, 190, 191, 193

France 20, 22, 28, 31, 33, 41, 60, 65, 227

freedom of religion 146

freedom of speech/expression 6, 32, 128, 145, $146,156,252$

French Revolution 5, 11, 21, 29, 33, 152-3, friendship 77, 83, 100, 108., 150, 176

Fukuyama, Francis 228

Galitzin, Prince Alexander 276

Gareli, Nicholás Maria 51

Gassendi, Pierre 64, 74

Gawlick, Gunter 167

Gilens, Martin 226, 239

Gladstone, William Ewart 232

Good, John Mason 168

Great Depression 144, 148, 157

Greece 65, 133, 166, 248; see Athens

Green, T. H., 15, 263, 290, 291, 293-5, 296-8, 302, 305, 306, 307

Grey, Edward 257, 258

Grotius, Hugo 31, 61

habit $25,68,111,123,130,163,170,173$, $197,212,232,248,253,270,279,280$, $282,284,285,289,299$

Hadleigh, Essex 281-2

Halévy, Elie 20, 68, 163

Hamilton, Sir William 72, 77

Hamilton, Alexander 75

happiness $1,4,7,8,9,10,12,14,15,16$, $20,21,23,25-7,31,41,68,98,101$, 108-10, 119, 127-9, 151-2, 154, 161-4, 169-71, 178-9, 185-6, 200-3, 208, 211, 212, 216-8, 220, 271-3, 276, 294-5, 301

Hare, R. M. 219

Harrington, James 233

Harrison, John F. C. 274

Hartley, David 72, 170

Hayek, F. A., 152 
hedonism 7, 98, 100, 107, 112, 185, 186, 193, 199, 220, 291-2, 298; evaluative hedonism 7, 99; explanatory hedonism 101, 112, 200; see pleasure and happiness

Helvetius, Claude Adrien 4, 21, 23-8, 30, 32, $33,67,68,75,87,170$,

Herodotus 163

Hitler, Adolf 231

Hobbes, Thomas 64, 72, 74, 75, 107, 155, 162, 170,234

Hollander, Samuel 13-14, 246-68

Home, John 66

honesty 100, 102 honestum 168

Humboldt, Wilhelm von 148-50

Hume, David 6-7 on the virtues 8-9, 38, ch 5, on scepticism ch 4;

Dialogues 77; Enquiries 6, 59, 62, 64, 75, 82; History 76; Treatise 6, 7, 59, 60, 61, $62,64,66,71,75,82,83,86-7$, see epicureanism

Hurka, Thomas 295, 296, 303

Hussein, Saddam 231

Hutcheson, Francis 7-8, 62, 64, 66, 67-8, 74, 98, 108-113, 166, 179

Huxley, T. H. 281

identity 102-3, 222-3

Idéologues 33

immutability-enacting clause 53, 54

impartiality 101, 102, 108, 111, 211

India 151, 162, 164, 226, 262, 263,

individualism, ethical 210, 222; vs totalising 208-214, 216-8, 219-223

infanticide 133

institutional design 240 , see constitutional design

interests $24,25,26,29,44,68,70,102,129$, $157,168,174,175,210$;

unenlightened 29

human interests 126;

public and private $27,55,188,190,191$, 192, 210-12, 222 ,

sectional interests 174-5, 226, 230, 234

sinister interests 45 ;

International Covenant on Civil and Political Rights (ICCPR) 152

International Covenant on Economic, Social and Cultural Rights 152

Ireland 234, 262-3, 272, 275, 277, 278, 283

Israel 13, 247-8, 263-4; Nation State Law (2018) 264

Jacobinism 264

Jefferson, Thomas 229, 232

Jewish question 13, 246-64

John VI 55

justice $9,15,27,60,64,70,72,83,84,87,92$, $101,120,122,126,128,149,168,170$, $174,191,192,197-8,214,215,220$, 250,303

Kant, Immanuel 210, 293, 305-6

Kelly, Paul 127, 131

Kojève, Alexandre 228 knowledge 43, 54, 86, 121-2, 124-5, 131, $168,170,172-3,174,232,239,255$, 279,303

La Follette, Robert 229

Lancaster, Joseph 162, 163, 170

Lancastarian Association 170

land ownership 273

law $6,25,27,28,31-2,45,48,51,54,68-70$, $119,122,126,127,131,145,154-6$, 191, 196, 232, 234, 240, 250,

legislators $10,25-6,27,31,53,54,69-70$, $119,123-5,126,128,129,131-2,144$, 190, 216, 229, 238, 239-40

legislation as an evil 123

Liberalism 5, 20, 34, 40, 152, 234; New Liberalism 302 of freedom 20; liberales 40, 56

liberty $3-4,14,20,31,52,65,76,118,119$, $122,127,149,186,199,253,256$

positive and negative 146 ; liberty of the ancients 233

liberty of the press $43,49,50,51,52,173$, 252; see freedom

liberal democracies 226, 228, 230, 232

libertarianism 6

Lindfield, Sussex 12, 271, 276-7, 278, 284

Lipset, Seymour M. 230

Livy 163

Locke, John 12, 25, 61, 64, 99, 107, 150, 151, 170, 270, 277, 280, 299

Loizides, Antis 7, 9-10, 161-183

lot $233,238,239,240$

Lucretius 168

Macaulay, Thomas Babington 162

Machiavelli 226, 228, 233

Mackenzie, J. S. 290, 293, 296, 297, 305, 306

Mackintosh, James 7, 73-4, 162

Madison, James 75, 228, 229, 233, 237, 241

Mander, W. J. 290, 293, 294

Mandeville, Bernard 108

marriage 281, 284

Marsilio of Padua 233

Marx, Karl 226, 284

mathematics, social 22, 26, 29

Maurice, F. D. 248

maximising 15, 20, 26, 208, 216, 217, 218, 220, 292, 297, 301, 302,

McCosh, James 72

McTaggart, J. M. E. 296, 303, 306, 307

Mill, James 7, 9, 10, 12, 17, 20, 33, 40, 59, 61, $71-5,161-79,274$

Mill. J. S. 1, 2, 6, 7, 8, 9, 13, 14, 16, 75, 76-7, 98, 118, 165, 179, 184, 185-202, 207-221, 225-6, 241, 248-57, 289, 290, 291-2, 297, 298, 302, 306

Logic 3, 76, 207, 208, 254, 259;

On Liberty 3, 202, 207, 208, 250, 254-7, 261,

Utiitarianism, 15, 113, 185, 207, 208, 209, 214, 219, 220, 250, 302

Anti-semitism 246-61; secondary principles 3, 4; see Art of Life

mixed government 11, 42, 236 
Mirabeau, Honoré-Gabriel Riquetti, comte de 22

moderation 76, 91, 111

Montesquieu, Charles Secondat baron de 65, 67, 166, 233

Mora, José Joaquin 49

Moore, G. E., 15-16, 193, 289, 290-5, 296, 297-8, 300, 301-2, 303-7

Moore, James 6-7, 59-80

moral pluralism 133

moral qualities 9,90 ,

moral sense 62, 71-2, 108, 110, 254

moral sentiment 24, 197, 199, 214, 257

Morning Chronicle 41, 164

Moyles, R. G. 283

Mussolini, Benito 231

Nadel, George 167

Napoleon III 231

natural affections 62, 102, 104, 106, 107

natural intellectual faculties 88

natural law 30, 61, 66, 68, 108,

natural rights $3,22,31,32,34,61,143,150$, 152-4

necessity 66, 146, 147, 157, 172, kingdom of 128

New Deal 144, 229

New Lanark 274-5

Nicholas I, Tsar 276

Nicolle, Margaret 277-8

Niebuhr, Reinhold 230

Nussbaum, Martha 118, 126, 129, 130, 134

O'Connor, Arthur 33

Olson, Mancur 230

Ortega y Gasset, José 227

Owen, Robert 12, 271-4, 275, 280-2, 284

Paley, William 163

Palestine 13

Pall Mall Gazette 282

parliamentary reform 10, 53, 161, 163-4, 174, 257,260

passions $9,23,25,29,32,60,62-4,71,84$, $86,88,92,100,171,174,175,188$

Paulus H. E. G. 248

perfectionism 8, 103-4, 110

Pericles 226, 234, 242

Phillips, David 292

Place, Francis 169, 170

Plato 9, 102, 105, 108, 110, 163, 164-5, 167, 168, 209, 222, 226, 233; Platonism 98, $99,150,210$

pleasure $1,4,7,26,27,60,64,69,75,76,88$, 91, 99-100, 101-5, 108, 112, 120, 121, 128, 163, 193, 211, 291; four dimensions 194-6

and good 292-8, 300-301

and happiness $8,10,102-3,104,105,109$, 197

higher and lower 7, 10, 14-15, 24, 25, 60, 104, 105, 109-113, 164, 184, 186, 191, 192, 196, 197, 198-9, 202, 298

and pain $23,24,25,67,69-70,82,100$, $109,110,111,119,120-3,132-3,134$, 161, 168, 169, 174, 176, 185 188-9, 211; quality vs quantity; 100, 105, 109, 110, 187, 194, 196, 197

and virtue $7,24,72,90,98,100-1,104$, $109,110,111,112,164,196-7,199$, 200, 201, 202, 300

sense vs intellect 102-5, 109, 110, 111, 130, 164, 169-73, 296

and utility $91-2$,

Pliny 163

politeness, rules of $61,64-5,100,166$

Polus 235

Polybius 226, 228, 233, 236

poor, the $12-13,121-2,129-30,161,169-70$, 235, 237, 239, 256, 269-273, 275-79, $281-5$

Portugal 40, 41, 53

Postema, Gerald 126, 129

poverty $27,64,127,212,271,272,274$. 280-5

power $28,43,45,48-51,52,54,55,65,76$, $121-3,127,134,148,150,153,173$, 175, 193-4, 200-201, 227, 228, 229-33, 237-8, 241, 253; sovereign 28, 55

praise and praiseworthiness $63,91,110$, 177-8, 192

Prichard, H. A. 296

Priestley, Joseph 67

primary and secondary rules/principles 3 , 4, 143, 154-6, 210, 215, 218-20, see Bentham, Mill

property $30,48,61,68-9,126,127,151,156$, 168, 221, 228, 237, 282, 284, 304

property qualification 30

public interest 25-7, 188, 230

public good 16, 112, 188

Pufendorf, Samuel von 31, 61

punishment $3,25,46,50,55,70,99,122-3$, 125, 132, 189, 191, 198, 227, 250, 270, 280, 285

puritanism 179, 185

Pyrrhonism 6, 59-61,

Quinn, Michael 16, 118-142

Quintilian 163

Ramsay, Chev. Andrew Michael 60-1

Ramsay, Michael 60

Rashdall, Hastings 15, 16, 209, 221-2, 290, 295, 296-305, 306-7

Rawls, John 20, 21, 128, 147, 222

Regulus 112

Reid, Thomas 7, 59, 61-2, 66, 72, 108

representation, political 28-9, 43, 45, 133, 175, 229, 232

Reynold's Newspaper 281

Richardson, Henry 226

Riego, Raphael del 41

rights $5-6,16,20,21,22,30-4,61,69,126-7$, $143,145,152-3,154,157,197-8,203$, 227, 228, 247

bill of rights 146, 150-2, 226-7;

conventions and covenants 152, 226

declarations of $30,31-2,143,151-2$; see securities; natural rights; property

Riley, Jonathan 14-15, 184-206

Rome 65, 237, 248 
Roosevelt, Eleanor 151

Roosevelt, president F. D. 5-6, 143-51, 153-4, 156-8, 229

Rothschild, Lionel de 259

Rosen, Fred 2, 4, 15, 17, 21, 40, 75, 88, 91 , $122,125-9,131,134,184-7,193-5,199$, 207-9, 225, 289-90, 306-7

Ross, W. D. 296

Rousseau, Jean-Jacques 25, 226, 228, 229 , 230, 231, 233

Russell, Bertrand 290, 294

Russell, Lord John 258-9, 262

Russia 276-8, 283

Ryan, Alan 16-17, 105, 225-245

sabbatarianism 248, 261

St Evremond 64

Salvador, Joseph 13, 248-9, 251-3

Salvation Army 12, 13, 271, 278, 280, 283

Say, Jean-Baptiste 33

scepticism 6, 59-61, 73, 74, 76, 77, 165

Schofield, Philip 2, 3, 10-11, 40-58

Schrauwers, Albert 273

Schumpeter, Joseph 226, 228, 239, 242

Scott, James C. 230

Scott, W. H., 67

second chambers in parliaments 41

securities (from misrule) 45, 51, 52, 55, 128, 143, 153

Sedgwick, Adam 254

self interest 21, 24, 101, 103-4, 108, 113, 123, 186-192, 194, 196, 199, 219, 255; see interests

self-love $60,61,64,107,175$

self-sacrifice $26,102,124,164,174,177,185$, 187, 190-2, 198, 200-3, 211-12, 223,

Sen, Amartya 16, 118-20, 122-4, 127, 129, 132, 133-4, 147, 149

sensibility $118,124,167$

sentiment $24,64,65,66,70-1,77,82,92,98$, 1991, 197, 199, 212, 214, 250, 257

Shackleton, Robert 67

Shaftesbury, Anthony Ashley Cooper, Earl of 7, 98-107, 108, 110, 113, 116

Shelburne, William Petty, Earl of 22

Sidgwick, Henry 15, 20, 102, 187, 193, 219, 289-300, 302, 304-7

Sidney, Algernon 233

Singer, Peter 134

Skinner, Quentin 3

Smith, Adam 21, 24, 63, 70, 75, 77, 108, 127 , $132,133-4,163,178$

Smith, Sydney 278

social contract 8,25

social feelings 212,215

Socrates 1, 14, 163, 165, 168, 177, 185-6, 17, 193, 198, 234, 235

South America 11, 41 - see also Ultramaria

Spain 11, 40-56

Spencer, Herbert 216, 281, 290, 291, 294, 297, 299, 306

Spinoza, Baruch 293

Stael, Anne Louise Germaine Necker, Mme De 33

Stalin, Joseph 228, 231
Stark, Werner 121

Stephen, Leslie 163

Stewart, Dugald 72-3, 165-7

stoicism 15, 110, 164, 172, 184-7, 199

Strahan, William 59

suffrage, extension 175, 227, 228, 232, annual 53 ,

Sumner, Leonard W. 132

sympathy $24,56,60,70,76,110,123,124$, $133,134,152,188,190$

Tacitus 163

Talmon, Jacob 231

Tasset, José L., 8-9, 81-97

Thomas, Norman 229

Thomson, Ann 30

Thrasymachus 235

Thucydides 163, 226

Tillet, Ben 281

Tocqueville, Alexis de 16, 17, 33, 156, 226, 233, 237, 241

totalizing principles 208-14, 216-23 see maximining

Traveller, The 49, 51

Truman, Harry 229

truth $29,71,76,87,106,106,145,150,167$, 216, 239, 256, 293, 298-299, 300

Turgot, Anne Robert Jacques 22, 24, 28, 32, 33

Ultramaria 10, 11, 41-5, 47-9, 55

United States of America 12, 50, 52, 144, 145, 151, 157, 228, 229, 231, 232, 233, 237, 238, 241-2, 270, 276-7, 281, 283; constitution 75, 145-6, 226

University of London 2, 169

utility $3,5,9,12,15,21,23,32,67,70-1$, $75,84,133,164,168,187,208,210$, 211-17, 220, 254; diminishing marginal 128-9, 154; and virtue 83-6, 88, 89-93, $120,123-5$

utilitarianism, 2-3, 118, 120, 129-30, 133, 184: classical 15, 20, 21, 81, 90, 91-2, 134, 289-91, 294, 296, 298, 301, 302, 307; Bentham's 121-4, 152, 163, 188, 190-2; Hume's 81, 90, 91-2; James Mill's 162-79; J S Mill's, 15, 113, 163, 184-6, 197, 201-3, 207-223, 250, 289-91

act/rule utilitarianism 85 ;

direct/indirect 84-5, 109, 125-6, 218-221 consequentialism 12, 33, 101-2, 120, 270, 289, 295, 302-3

ideal 15-16, 289-307;

negative $127-8$

welfare 16, 32, 127 see happiness;

maximisation; pleasure; self-interest

International Society of Utilitarian Studies 12

utilitas 63, 177; Utilitas 2

Varennes, flight to 5, 22

véracité 29

Virgil 163

virtues 7-8, 15, 24

natural vs artificial 60

pleasures of 105, 110, 111 
Bentham 66-70, 81-93, 184-92; Hume 8-9, 60-6; 81-93; Hutcheson 107-113; James Mill, 167- 79; John Stuart Mill 15, 72, 77, 113, 184, 196-203, 211, 219-20; Hastings Rashdall 300-6; Shaftesbury 98-107

Vivenza, Gloria 172

Voltaire 21, 22, 248

Wakefield, Edward 170

Weber, Max 228, 231, 236

Weinstein, David 15, 289-312

Welchman, Jennider 290

well-being 5, 7, 21, 27, 33, 98, 101, 104, 107-9, 119-24, 127-8, 168, 170, 174, 177, 207, 209-10, 214-5, 220, 289, 301, 304
Whewell, William 186

Whichcote, Benjamin 99

Williams, Bernard 219

Wilson, Woodrow 229

Wolff, Robert P. 231

women 30, 44, 130, 131, 232, 235, 281

world wars 143, 144, 227

Xenophon 108, 163

Zeno 172

Zionism 13, 246 
Happiness and Utility brings together experts on utilitarianism to explore the concept of happiness within the utilitarian tradition, situating it in earlier eighteenth-century thinkers and working through some of its developments at the end of the nineteenth and beginning of the twentieth centuries. Drawing on a range of philosophical and historical approaches to the study of the central idea of utilitarianism, the chapters provide a rich set of insights into a founding component of ethics and modern political and economic thought, as well as political and economic practice. In doing so, the chapters examine the multiple dimensions of utilitarianism and the contested interpretations of this standard for judgement in morality and public policy.

The chapters are written in celebration of the career of Professor Frederick Rosen. They follow his work by concentrating on Bentham and the two Mills, and by the subtleties and sophistication of their understanding of one of the most alluring but elusive ideas of modern times. The volume will be of interest not only to admirers of Rosen but to academics and postgraduate students in disciplines such as Philosophy, Political Theory, History of Political Thought, Legal Theory and Legal History.

Georgios Varouxakis is Professor of the History of Political Thought at Queen Mary University of London, and Co-director of the Centre for the Study of the History of Political Thought. His books include Liberty Abroad: J. S. Mill on International Relations (2013) and Mill on Nationality (2002). He is currently writing The West: The History of an Idea for Princeton University Press.

Mark Philp is Professor of History and Politics at the University of Warwick, and an Emeritus Fellow of Oriel College, Oxford. His books include Political Conduct (2007), Reforming Political Ideas in Britain: Politics and Language in the Shadow of the French Revolution (2013), and he is co-editor of Napoleon's Hundred Days and the Politics of Legitimacy (2018). 